$12-2015$

\title{
The Secret History of the Mongols: A Mongolian Epic Chronicle of the Thirteenth Century
}

Igor de Rachewiltz

The Australian National University

Follow this and additional works at: https://cedar.wwu.edu/cedarbooks

Part of the Asian History Commons, and the East Asian Languages and Societies Commons

\section{Recommended Citation}

Rachewiltz, Igor de, "The Secret History of the Mongols: A Mongolian Epic Chronicle of the Thirteenth Century" (2015). Shorter version edited by John C. Street, University of Wisconsin-Madison. Books and Monographs. Book 4. http://cedar.wwu.edu/cedarbooks/4

This Book is brought to you for free and open access by the Books and Monographs at Western CEDAR. It has been accepted for inclusion in A Collection of Open Access Books and Monographs by an authorized administrator of Western CEDAR. For more information, please contact westerncedar@wwu.edu. 


\section{The Secret History of the Mongols}

A Mongolian Epic Chronicle of the Thirteenth Century

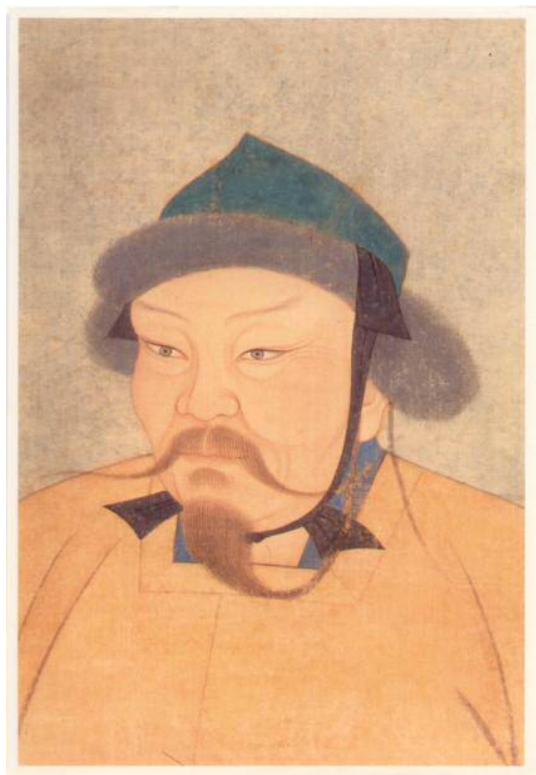

TRANSLATED BY IGOR DE RACHEWILTZ

The Australian National University

SHORTER VERSION

Edited by John C. Street

December 11, 2015 


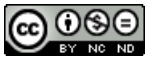

The Secret History of the Mongols, Translation by Igor de Rachewiltz is licensed under the Creative Commons AttributionNonCommercial-NoDerivatives 4.0 International License. To view a copy of this license, visit www.creativecommons.org.

Cover illustration: Ögödei Qa' an (Ogedei Khan), third son and successor of Činggis Qan (Genghis Khan, ?1162-1227), reigned from 1229 to 1241 . He was the real founder of the Mongol empire and, in the author's opinion, he played an essential role in the composition of the Secret History of the Mongols.

Colour on silk, date unknown (? $\left.14^{\text {th }} \mathrm{c}\right)$. Courtesy of the National Palace Museum, Taipei. 


\section{CONTENTS}

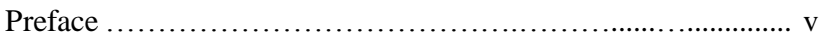

Abbreviations and Special Conventions ...................................... vi

Introduction ............................................................. vii

Origin and History of the Text ...................................... viii

The Secret History as History and Literature .............. xvi

Later Editions and Translations of the Text .............. xviii

The Present Translation .................................... xx

Translation

Chapter 1 ...................................................................... 1

Chapter 2 ................................................................. 16

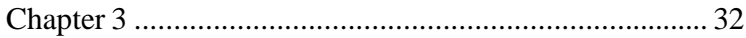

Chapter 4 .............................................................. 50

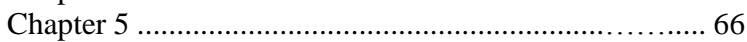

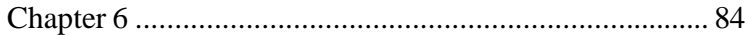

Chapter 7 ................................................................. 102

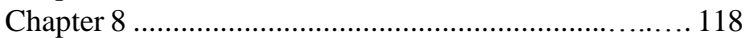

Chapter 9 ........................................................... 134

Chapter 10 ............................................................. 150

Chapter 11 (= Sup. 1) ……………………………….... 165

Chapter 12 (= Sup. 2) ………………………………..... 185

Index of Proper and Place Names ........................................... 207

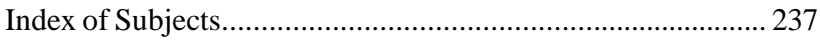

Literature and Abbreviations .................................................... 260

Table: Genealogy of Činggis Qan ............................................. 266

Map 1: Mongolia ca. AD 1200 ................................................. 270

Map 2: Eurasia ca. AD 1210 ………………………………..... 271 



\section{PREFACE}

The pages below represent a shortened version of the three volumes - totaling over 1700 pages - of Igor de Rachewiltz's similarly-titled work published by Brill in 2004 and 2013.

The first two of these volumes provides a full English translation of the $13^{\text {th }}$ century Middle Mongolian text known as the Secret History of the Mongols, with lengthy introduction explaining the nature and origin of that text (with much background information) plus detailed commentary on details in this new translation. After these come seven appendixes, full bibliography, and indexes of names, subjects, grammar and lexis. The volumes include also various maps and illustrations, and a table showing the genealogy of the man named Temüjuin who became Činggis Qan - better known in the west as Genghis Khan.

Volume 3 consists of addenda and corrigenda to the earlier two, correcting a number of minor errors and omissions discovered after publication, and adding information provided by newly published works or other scholars.

Publishing such a massive work must, of course, have been very expensive, and Brill can scarcely be blamed for passing such expense on to purchasers. But the high price for all three books makes it likely that most copies will remain in libraries or be owned by specialists or one sort or another. The de Rachewiltz translation deserves a much broader audience, for unlike earlier attempts in English, it is pleasant and easy to read while remaining close to the spirit of the original.

It is hoped that the present shortened version of this invaluable work will be useful to students in various fields of study other than merely linguistics, philology, and Mongolian studies: to students of history, cultural anthropology, and geography, for example, or East Asian or Central Asian studies in general. And that it may give pleasure to many general readers as well.

John C. Street

14 June 2015

Madison, Wisconsin 


\section{ABBREVIATIONS AND SPECIAL CONVENTIONS}

Common and conventional abbreviations are not listed

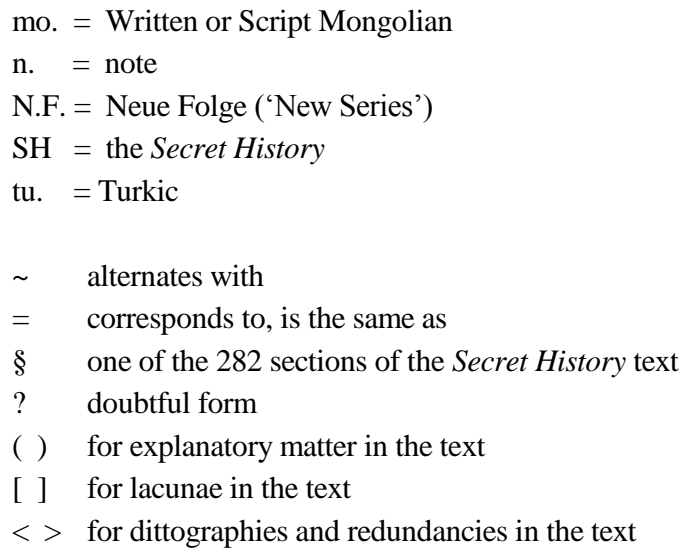

In the translation only:

Italic type is used for English words added by the translator Monotype Corsiva type is used for a few Mongol and foreign terms retained in their original form

We are extremely grateful to Prof. Dr. Manfred Taube for allowing us to include, at the end of the present book (as in the longer version of 2004), a table based on that in his Geheime Geschichte der

Mongolen. Herkunft, Leben und Aufstieg Dschingis Khans. 


\section{INTRODUCTION}

'The $13^{\text {th }}$ century work known as the The Secret History of the Mongols (Mongqol-un niuča $[=n i ' u c ̌ a]$ to [b]ča'an) is the earliest and most important literary monument of the Mongol-speaking people... . [It] is the only genuine (not to be confused with reliable) native account of the life and deeds of Činggis Qan our Genghis Khan - one of the world's outstanding figures.'

So begins the Introduction (pp. xxv-lxxxii) to de Rachewiltz's volumes of 2004-2013, hereinafter abbreviated RSH, the chief points of which are summarized below.

The author continues: In form, too, the Secret History is unique, 'for no other nomadic or semi-nomadic people has ever created a literary masterpiece like it, in which epic poetry and narrative are so skilfully and indeed artistically blended with fictional and historical accounts.' 'Its poetry reflects the pure, unmitigated tradition of the nomadic tribes of Mongolia and of the Turkic- and Mongolian-speaking inhabitants of the vast steppe-lands of Inner Asia.' ${ }^{\text {, }}$

'Linguistically too, the Secret History provides the finest and richest source of Preclassical Mongolian (in its reconstructed "written" form) dating from the first half of the 13th century, and of Middle Mongolian, the language actually spoken in the second half of the 14th century - a language lacking any artificiality, simple and direct in style, [and] far removed from the learned and often convoluted syntax of so-called Classical Mongolian. In this respect, one can say with A. Waley that its "story-tellers' tales... are some of the most vivid primitive literature that exists anywhere in the world", words echoed by F. W. Cleaves who called the Secret History "one of the great literary monuments of the world".,

Although at a later date the text was divided quite arbitrarily into twelve or fifteen chapters and 282 sections or paragraphs, 'the Secret History is a continuous narrative with comparatively few lacunae and interpolations in the text.... The order of events discussed is chronological, but the first date, corresponding to AD 1201, appears only in $\$ 141$ (Chapter 4). Chapters 1-12 (up to \$268) describe the life and career of Činggis Qan from his birth, probably in 1162 (\$59), to his death 
in 1227 (§268), prior sections being devoted to his ancestry and the legendary origins of the Mongol tribe and clans. The final portion of the work ( $\$ \$ 269-281$; see below) deals with the election of Ögödei Qa'an....and with some events of his reign (1229-41), without however mentioning his death. The narrative ends (\$282) with a brief and apparently incomplete colophon recording where and when our text was completed.'

\section{Origin and History of the Text}

The colophon just mentioned is deceptively precise: it states that 'The writing was completed at the time when the Great Assembly convened and when, in the Year of the Rat, in the month of the Roebuck, the Palaces (ordos) were established at Dolo'an Boldaq... .' The month of the Roebuck is the seventh lunar month, but to which Year of the Rat (in the duodenary animal cycle) does the colophon refer?

This whole matter has been extensively discussed by writers over the past seventy-five years. ${ }^{3}$ At first the year 1240 was generally assumed, though our sources report no Great Assembly (yeke qurilta) for that year. The prior Rat Year was 1228 , and such an assembly was in fact scheduled for that year called to choose a successor to Činggis Qan, who had died just a year earlier - but at least partly because of internal dissention participants did not actually assemble until August of $1229 .{ }^{4}$

Čnggis had designated his third son Ögödei as his successor, but it was Tolui, the fourth and youngest son (and thus by Mongol tradition 'keeper of the hearth') who had assumed temporary control of the empire after his father's death. Some participants instead supported the candidacy of Ča'atai (= Chagatai), the eldest surviving son. ${ }^{5}$

As matters turned out, the father's wishes were respected, and Ögödei was eventually chosen to rule the empire; he did so with notable success for twelve years. But that decision was not easily reached: even after the yeke qurilta actually met during the autumn of 1229, both Chinese and Persian sources show 'that there was disagreement in the assembly and that factional strife delayed the proceedings until almost mid-September. ${ }^{6}$

Thus it appears that the Secret History was in fact completed just in time for oral presentation at this assembly; it must then have "strengthened the hand of the "conservative" element 
at court which supported Ögödei's candidature in accordance with Čnggis Qan's will., ${ }^{7}$ One could in fact suggest that the one-year delay until 1229 resulted in part from an attempt on the part of followers of Ögödei's to gain support for their cause by composing the present text: to explain for younger listeners all that had transpired during the lifetime of Činggis Qan, and to emphasize for all listeners the importance of maintaining traditional Mongol ways.

$* \quad * \quad *$

Just who composed or compiled the original version of our text has never been definitively established. Clearly it was one or more family members or other individuals with intimate knowledge of all that had gone on during the lifetime of the man named Temüjuin who eventually became Činggis Qan. ${ }^{8}$ The most likely candidate has long seemed to be one Šigi Qutuqu (ca. 1180-1260), who at an early age had been adopted by Činggis's mother, and eventually became one of the Qan's most trusted associates; in 1206 he was appointed grand judge and entrusted with the keeping of legal and population records. ${ }^{9}$ But many readers of Igor de Rachewiltz's recent works have now become intrigued (if not fully convinced) by the author's suggestion that it may well have been Ögödei himself who wrote some or all of the earliest version of out text, or at least directed the whole compilation of this text. ${ }^{10}$

However this may be, the first version of our text must originally have been written in the Uighur script (adapted to Mongolian by 1206), and was presumably referred to by its original first line: Činggis Qan-u uja Qan.'

No copy has survived of the hypothetical earliest version of the Secret History to which the colophon properly applied. What we know today as the Yüan ch'ao pi-shih 元朝秘史 (Secret History of the Yüan Dynasty), or Mongqol-un niuča to[b]ča'an (Secret History of the Mongols), is a much altered, expanded, and elaborately edited version of the Mongol text that was first printed shortly after 1400 . Precisely how these two versions are related, and just why, where, and when specific changes were made are matters as yet not fully understood: reconstruction of the textual history 'is still to a large extent conjectural., ${ }^{11}$ 
Most changes in the original text apparently took place during the reign of Qubilai Qa'an (1260-94), son of Tolui. It was at this time that 'research into the earlier history of the Mongol ruling house was officially promoted with the establishment in 1261 of a Department of National (= Mongol) History... within the College of Literature or Han-lin Academy... ., ${ }^{12}$ There scholar-officials 'collected all the written sources available and prepared drafts in Mongolian (ca. 1290). These were duly revised and translated into Chinese. The [resultant] Mongol chronicle was known simply as Tobčiyan or History; its Chinese counterpart was the Shih-lu 實錄 or Veritable Records. The records of Činggis' and Ögödei's reigns...were completed in 1303.' It was probably texts of this sort, written in the style of the Činggis Qan-u uja zur (but that on Ögödei never completed), that were eventually incorporated into the Secret History as 'supplementary chapters' 11 and 12 (see below).

At the same time, but independently, some unknown editors apparently tried to 'improve' the Činggis Qan-u ujayur by '1) introducing new material, including the passages favourable to the house of Tolui to which Qubilai also belonged; 2) expunging references to events and personages no longer approved of... ; and 3) altering titles to confer posthumous honours on the imperial ancestors. ${ }^{13}$ As an example of their meddling with the text, one may mention the word qa'an (mo. qayan). This Old Turkic title, used for a supreme ruler, was first adopted as imperial title and personal epithet by Ögödei after his election in 1229. Sometime around $1266,{ }^{14}$ early in the reign of Qubilai, this $Q a^{\prime}$ 'an was substituted for $Q a n$ whenever the latter occurred after Činggis in the original text - except once in $\$ 255$, 'due to an oversight.' 15 The same change was made for Činggis Qan's 'most illustrious ancestors, both direct and collateral (Qabul, Qutula, Ambaqai, Yisügei)., 16

But most revision was probably a gradual process, 'carried out in all likelihood during Qubilai's reign' by Mongols: for 'one cannot detect any Chinese historiographical bias or influence in the text itself.' ${ }^{17}$ The eventual result may be called the Cinggis

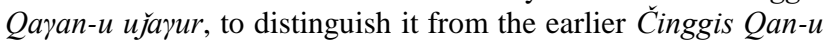
ujayur. This altered text - or some intermediate version - is additionally reflected in the Altan Tobči, a text in the Uighur 
script containing much of the Secret History, a manuscript of which was discovered in Mongolia only in $1926 .{ }^{18}$

In early 1369, immediately after the fall of the Yüan dynasty, historiographers of the College of Literature began serious work on compilation of the official history of the previous dynasty, the Yüan-shih 元史. Investigators retrieved from the secret archives of the former Imperial Library a variety of documents including at least two copies of the late $13^{\text {th }}$ century Činggis Qayan-u ujayur (one surely in Uighur script), and an additional text on the reign of Ögödei. ${ }^{19}$

These copies were not used during preparation of the hastily-completed official history of the Yüan, but 'attracted the attention of the Mongol and Chinese scholars in the College of Literature. $^{20}$ It was they who added to the older text two final, 'supplementary' chapters that dealt first with Činggis Qan's campaigns from 1215 until his death in 1227, then (less coherently, in $\S 269-281$ ) with events during the years of Ögödei’s rule, but including no mention of his death. They then 'transferred the original colophon to the end of [these twelve chapters] and made a free summarized version in Chinese of the entire text using one of the copies in Uighur script. Subsequently they prepared an interlinear phonetic transcription with a word by word interlinear translation into Chinese.' (An example is shown in Figure 1 below.) By 1382 this whole work, which lacked a 'proper' title, was renamed Yüan pi-shih 元秘史 or Secret

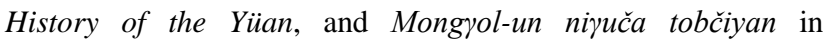
Mongolian, 'the latter being merely the Mongol counterpart of the Chinese title.'

During this same period (1369-98) the Ming government decided 'to train Chinese students as interpreters ${ }^{21}$ in their dealings with the troublesome neighbours on the northeastern frontier, [and] the College of Literature prepared a basic SinoMongolian glossary with the Mongol words given in phonetic transcription, followed by a reader consisting of twelve official documents in Mongolian, interlinearly transcribed and translated into Chinese... . The work was published in 1389 under the title of Hua-i i-yü 華夷譯語 or Sino-Foreign (=Mongolian) Vocabulary. $^{22}$ 
During preparation of this work, the Yüan pi-shih had been mined for words to be included in the Hua-i $i$-yü vocabulary. At some point it was decided to supplement the Hua-i $i$-yü's vocabulary and bureaucratic texts (some with quite complex syntax, and thus difficult for students) by using the entire text of the Yüan pi-shih: 'i.e. the continuous free translation and the already "processed" Mongol text, to provide 1) an additional rich source of language material for future interpreters, and, at the same time, 2) a vast store of sundry information on the lore and customs of the Mongols.' The aim of the editors at this period 'was essentially linguistic', so - fortunately for us - they 'did not interfere with the text itself nor with the contents of the book, and they totally ignored problems of chronology, internal contradictions and historical accuracy.'

It must have been at this time, too, that Chinese editors divided the existing text into chapters and sections. The edition published for the first time probably during the years 1403-05 contained twelve chapters of almost equal length, but a version to be included in the monumental Ming encyclopedia Yung-lo tatien 永樂大典 (compiled in 1403-08) had fifteen. Division into 282 sections or paragraphs was the same in both, but in many cases quite arbitrary. In the Yung-lo ta-tien version the title was altered to the now-familiar Yüan ch'ao pi-shih 元朝秘史.

'Thus, by 1408 we may assume the existence of three texts of the Yüan (ch'ao) pi-shih: (A) the printed text in $12(10+2)$ chapters, (B) the manuscript copy of the Yung-lo ta-tien in 15 chapters, and (C) the manuscript, originally copied for the Yunglo ta-tien (in 1404), of the free summarized translation also in 15 chapters.' 'All the later manuscripts and printed editions of the text in transcription, i.e. of our Secret History, derive from A and $\mathrm{B}$, and all the manuscripts and printed editions of the free summarized translation derive from C.' Of the early 12-chapter version only 41 leaves have survived, and these were included in the photographic reproduction of the entire text published by the Commercial Press of Shanghai in 1936. (The remaining pages there come from manuscript $\mathrm{Y}^{2}$, the so-called ' $\mathrm{Ku}$ certified text' made in 1805, 'which is regarded as the best modern edition.') The original text of 15-chapter Yung-lo ta-tien edition was lost, 'probably during the Boxer War and the destruction of the 
College of Literature in Peking in 1900'; but some manuscript copies have survived - as, almost miraculously, has $\mathrm{C}$.

A few remarks may be appropriate here concerning the formatting and transcription in Chinese printed versions of the Secret History text. Figure 1 below shows the first two leaves of Chapter 1 of our text. These are here very severely reduced in size from leaves of the above-mentioned $\mathrm{Ku}$ certified text of 1805; and here the vertical dimension has been increased slightly for better legibility. It is stated on the verso side of the title page of the Commercial Press edition of 1936 that the printed area on a half-leaf of the original edition of 1403-05 was 24 x $18 \mathrm{~cm}$, or roughly $91 / 2 \times 7$ inches. When one realizes that the entire text occupied some 610 leaves of the sort shown below, the amount of work required to incise such wooden printing blocks is truly astonishing, not to mention all the time and labor put in by the earlier editors.

It will be noted that the title shown at the beginning of the text on leaf one (the extreme upper right hand corner here) is the newer Yüan ch'ao pi-shih, while at the leaf-fold line on each leaf we find the older and simpler title Yüan pi-shih. Beneath the latter is the chapter number ('one'), and lower down the leaf numbers ('one' and 'two' respectively). At the end of each section is given the free Chinese summary-translation of the whole - in much smaller characters.

Each side of a leaf is divided into five columns, to be read, of course, from right to left. Within these, each syllable of the Mongol text is transcribed phonetically, proper names indicated as such, and other syllable-sequences broken into bracketed sequences demarcating words and suffixes. In the edition by Kuribayashi from which Figure 1 is reproduced, each page of the sort shown here is faced by one romanizing the Mongol text, line by line. In this case the following romanization is given for the start of $\mathrm{SH} \$ 1:^{23}$

01:01:01 Mongol-un niuča to[b]ča'an

01:01:02 Činggis_qahan-nu huja'ur

01:01:03 de'ere tenggeri-eče jaya'atu töre=ksen Börte_čino a=ju'u .

01:01:04 gergei in-u Qo'ai_maral a=jia'i . Tenggis ketül=jü ire=be .

01:01:05 Onan_müren-nü teri'ün-e Burqan_Qaldun-na nuntuqla=ju

01:01:06 töre $=$ ksen Batačiqan $a=\breve{j u}$ 'u 


\begin{tabular}{|c|c|c|c|c|c|c|c|c|c|c|}
\hline 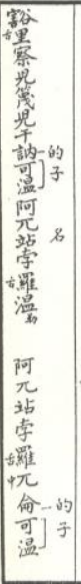 & 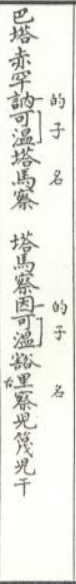 & 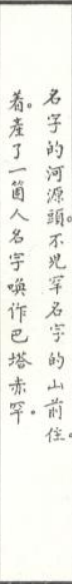 & 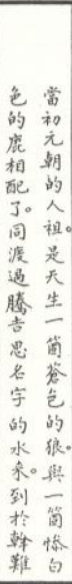 & 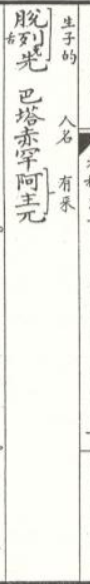 & 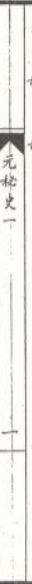 & 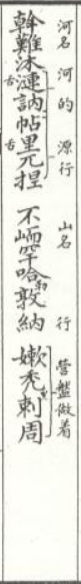 & 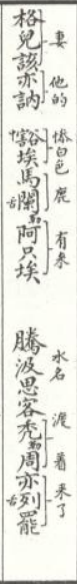 & 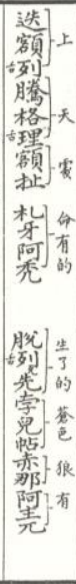 & 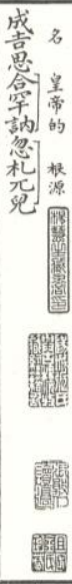 & 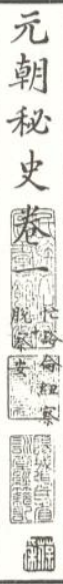 \\
\hline
\end{tabular}

[3]

\begin{tabular}{|c|c|c|c|c|c|c|c|c|c|c|}
\hline 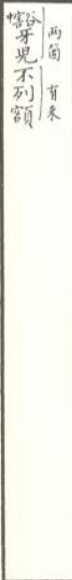 & 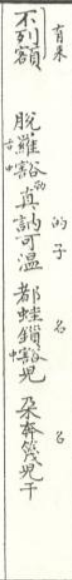 & 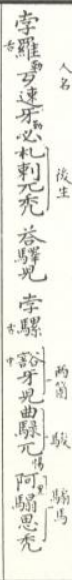 & 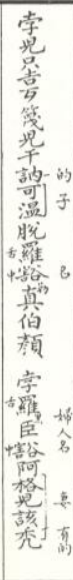 & 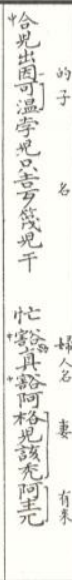 & 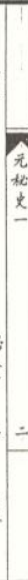 & $\begin{array}{l}+ \text { 合生 } \\
\text { 光出的。 } \\
\text { 予。 }\end{array}$ & 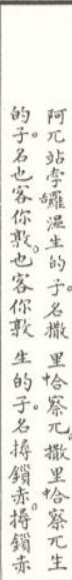 & 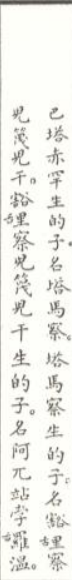 & 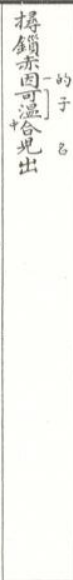 & 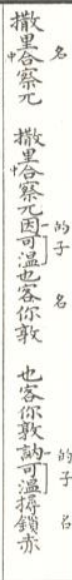 \\
\hline
\end{tabular}

$-7-$

FIGURE 1: First two leaves of manuscript $\mathrm{Y}^{2}$ of the Secret History (reproduced from KCI [= Kuribayashi 2001], p. 7, where a page number and section numbers 1 through 3 were included) 
The Chinese translation follows; then the initial lines of $\S 2$.

Contrasting with the immediate contiguity of sequential characters in the Chinese translation here (which follows normal Chinese practice within sentences), the columns of Figure 1 show notable differences in spacing between the Chinese characters here used to transcribe the Mongolian phonetically. It seems clear that 14 th century editors attempted to use such differences in spacing as a kind of punctuation: ${ }^{24}$ characters representing syllables of Mongolian were grouped together (without significant intervening blank space) into sequences of one or more words that formed syntactic units; and larger blanks between successive groups indicated more significant syntactic breaks than smaller ones (or terminal silence at sentence-end). Thus, for example, in Kuribayashi lines 01:01:05-6 we find:

[5] Onan_müren-nü teri'ün-e / Burqan_Qaldun-na /

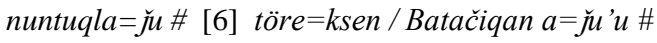
Literally this is:

'Onan River-of head-at / Burqan Qaldun-at settle=ing \# be-born=ppl. / Batačiqan be=past \#'

And in proper English:

'When [they had] settled on [Mt.] Burqan Qaldun, at the head of the Onan River, Batačiqan was born [to them].'

Here, in both languages, the essential clause 'Batačiqan was born [to them]' is modified by the much longer adverbial phrase. ${ }^{25}$

But this attempt to use spacing as punctuation was doomed to failure, for it now seems that copyists who struggled with this system quite successfully in Chapter 1 of the Secret History and in parts of Chapter 2, paid less and less attention to this difficult spacing later on in the text. For it must have been indeed problematic to format or copy spacing of this sort while trying to fit different numbers of words, each varying greatly in length, into each of hundreds of relatively short columns. Traces of this punctuation can be found in later chapters, but there such differences in spacing are rarely of real help to the reader.

As for Chinese transcription of the Mongolian on leaves such as those in Figure 1, de Rachewiltz rightly points out (lxv) that this 'gives us only the phonetic representation of how the Ming transcribers read the manuscript of the Secret History in Uighur script in the second half of the $14^{\text {th }}$ century. Therefore, 
the text in transcription does not reflect the spoken language of the time of composition, viz. the language spoken by Činggis Qan, or, at any rate, in the Mongol court milieu of the early $13^{\text {th }}$ century.' Among the phonetic changes that were taking place during this period are the following, ${ }^{26}$ at some point the vowels $\ddot{i}$ and $i$ fell together as $i, q(i)$ became $k(i)$, initial $h$ dropped; any sequence of two identical vowels (with intervening apostrophe) became a single long vowel $\bar{a} \bar{e} \bar{o} \bar{o} \bar{u} \bar{u}$, and under certain circumstances an $a$ was assimilated to $o$ or $u$. Note too that the phonetic value of many Middle Mongolian phonemes is still uncertain. In short, we simply don't know what the Secret History actually sounded like when presented orally at the Great Assembly of $1229 .{ }^{27}$

\section{The Secret History as History and Literature}

Writers have differed over the years as to the importance of our text as a historical document, some underestimating its unreliability, others considering it virtually useless as a historical record. And in fact 'trying to separate all the purely historical facts from the semi-fictional or wholly fictional accounts in the Secret History is an extremely difficult and often impossible undertaking.' 28 For the text is really 'a clever mélange of historico-narrative prose and epic poetry constantly and unexpectedly blending fact and fiction'; hence an 'epic story (or account) of Činggis Qan', or in Pelliot's phrase, an 'epic chronicle.'

The real importance of the Secret History lies in its 'faithful description of Mongol tribal life in the $12^{\text {th }}$ and $13^{\text {th }}$ centuries, especially with regard to the role of the individual in that society. In this respect, the Secret History is a true mine of information. The central theme of our epic chronicle is the modus operandi of one dominating figure who, together with the other leading characters - his family and retainers - skillfully manipulates the society of his time to achieve his one goal, viz. tribal supremacy for himself and his clan against innumerable odds.' ${ }^{29}$ And one message conveyed in unequivocal terms is that 'success as a leader cannot be achieved without good fortune and strength bestowed by Heaven and Earth, and the loyalty of one's retainers and subjects. Such a leader, then, rules by the will of Heaven, i.e. by divine right. It goes without saying that the process 
cannot operate successfully without the leader observing on his part the principle of reciprocity, i.e. reward, care and protection, towards his followers and dependants. This conception has an almost exact counterpart in medieval Europe and is the cornerstone of the feudal system.'

No less important than such concern with the 'aristocracy of the steppe' are other aspects of our text's portrayal of the social history of the Mongols prior to their entry onto the world stage. Reading through its sections and chapters one 'gains constant insights, more than just glimpses, into the lives of ordinary people and the interplay between chiefs and subordinates.' Aside from the information supplied on the military organization of the Mongols under Činggis Qan and Ögödei, the Secret History provides an unparalleled and detailed picture of nomadic life, social stratification, and the material culture of the medieval Mongols. It is a veritable encyclopedia on life in early Mongolia, during the short and critical period when the Mongols passed from the stage of nomadic tribalism to that of a tribal federation and steppe empire.

In addition to recording for his successors - and for posterity - Činggis Qan's 'wisdom and organizational skill and foresight, the Secret History also sings the praise of the other (and perhaps the true) heroes in the saga - the valiant companions from early days such as "the four hounds" and "the four steeds", ${ }^{30}$ as well as the commanders of a thousand without whose total commitment to their leader, Činggis would have remained one of many tribal chiefs in northern Mongolia.' These heroes 'are real people (even if at times colourfully portrayed as supermen) and their feats on the battlefield, in spite of the occasional reverse, are only too true. It is in this regard that the Secret History is for us a special document: it adds both flesh and soul to much that we learn from the Persian and Chinese historians by giving us the facts as seen, or perceived, from the Mongol camp, in other words "from the inside".'

The Secret History is perhaps most notable in that it "has no precursor nor real successor in the Mongolian historiographical tradition.' It is further the sole true literary monument of the pre-Buddhist period in Mongolia, before the increasingly heavy impact of Buddhism and the Tibetan culture. A third and more immediately obvious characteristic is the presence of some 
165 rhymed passages that are interspersed throughout the text: over one-third of the entire work is in alliterative verse, i.e., in poetic form. Such epic pieces, most stemming from the preliterate period, 'were originally sung by the story-teller, following the ancient tradition of the Mongol and Turkic bards.'

It must be remembered that for both the Mongols and the Turks of this period writing was a new and unfamiliar medium, 'used for very definite purposes confined almost entirely to state and administrative matters.' ${ }^{31}$ Compilation of a text as long as the Secret History would have been a major undertaking, and its completion implies some strong underlying motive: it must have been intended not only to record 'the deeds and pronouncements of Činggis Qan, but also those of his faithful companions in a language and style that reflect the attitudes and values of contemporary Mongols. It is at the same time a glorification of the conqueror's clan for the sake of posterity, especially of his immediate successors.' One is reminded of Alan Qoa's prophetic words near the start of the Secret History, in $\$ 21$ :

'When one understands that, the sign is clear:

They are the sons of Heaven. ...

When they become the rulers of all

Then the common people will understand.'

\section{Later Editions and Translations of the Text}

The first attempt at transcription into a western alphabet of the Chinese phonetic transcription of the Secret History was made in Russia by Palladǐ in 1872-78 but never published in full. (That same scholar, who did not know Mongolian, had published a translation of the Chinese free translation in 1866.) An annotated translation into Japanese by Naka Michiyo appeared in 1907, and it is to him that de Rachewiltz has dedicated his third volume of 2013. But full transcriptions and translations (full or partial), did not become widely available in the west until after World War II. A French transcription was completed by Paul Pelliot in 1920, but not published (with partial translation) until 1949, after his death. German, Russian, and Japanese publications by Haenisch, Kozin, Shiratori and others, ${ }^{32}$ available to only a few during the War, became more widely known some years later. The most important of these were three works by Erich Haenisch: his German translation of the entire Secret 
History (1937, 1948), a full transcription of the text (with variant readings in editions $\mathrm{Y}^{1}, \mathrm{Y}^{2}$, and $\left.\mathrm{Y}^{3} ; 1937,1962\right)$, and a dictionary of the Secret History text $(1939,1962)$. Mongol scholars were similarly active during this period, and a Turkish translation by Ahmet Temir was published in 1948 .

For a full list of translations in chronological order up through 2001, see RSH lxxii-lxxiv; a similar list of transcriptions appears on lxxi-lxxii. Here one will also see names of the many scholars who have more recently made contributions to Secret History studies. Numerous additions to the lists were made, relating to reprints and works in a wide variety of languages, in RSH 3.8-9 and 19-27. The Introduction in Volume 1 of de Rachewiltz's magnum opus concludes with two pages on modern and contemporary studies on the Secret History, then 374 endnotes to the earlier text.

As for translations into English, only two of the older ones need mention here. The first, included in a book by Arthur Waley published in 1963, was merely a partial but quite readable translation of the Chinese summarized version. The second is a truly scholarly work, 'of paramount importance'; ${ }^{33}$ written by Francis Woodman Cleaves of Harvard University in conjunction with Fr. Antoine Mostaert - both authors of important linguistic works on Mongolian of various periods - this is entitled The Secret History of the Mongols; For the First Time Done into English out of the Original Tongue and Provided with an Exegetical Commentary. It contains the first full English translation of the Secret History text, with 65-page introduction and hundreds of footnotes to the translation. Although published only in 1982, this work had been effectively completed twentysix years earlier. ${ }^{34}$ And despite being panned by several reviewers for the author's use of King James English in the translation ('to conserve the archaic flavor of the original' in Mongolian, says Cleaves on p. xi), this remains a truly excellent translation. It is especially useful to anyone trying to learn the Middle Mongolian language, for Cleaves' translation is more literal than that reproduced in the present volume, attempting 'a meticulously literal rendering of the Mongolian text' (RSH lxxx). Unfortunately the planned commentary volume never appeared; nonetheless, the work is so important that four pages of additions and corrections are included as an appendix in RSH 2.1060-63. 
Needless to say, however, the more readable and indeed elegant translation included below will be of far greater interest to the general reader.

\section{The Present Translation.}

The translation presented below is virtually identical with that in the original publication of 2004 , with only the very few changes mentioned on pages $30-32$ of the third volume published in 2013. Like the original, it seeks 'a compromise between faithfulness to the Mongolian original and readability', and 'is primarily designed to provide the reader with an accurate but at the same time fairly fluent translation into modern English.' ${ }^{35}$ The conventions utilized in the translation are also unchanged: italic type is used for words not in the Mongolian text but supplied by the translator, while a special font, Monotype Corsiva - more delicate and elegant than the italics normally employed - shows Mongolian words (other than personal or geographic names) that are retained in their original form, and words from other languages such as Chinese or Turkish. For discussion of such matters, see RSH lxxxi; see also p. vi of the present work for abbreviations and conventional signs utilized in the translation.

The footnotes accompanying the translation have been considerably modified in the present version. Of such notes it was said (RSH lxxx-lxxxi) that these were intended 'to assist [the reader] in solving immediate problems of interpretation without constantly referring to the Commentary, and to advise the reader whenever checking the Commentary is indispensable for a full understanding of the passage. Hence also the numerous crossreferences in the footnotes to other passages and to differently spelled proper and geographical names. Like most works of this kind, the same name can recur in slightly different forms. Thus the footnote serves as an instant aid to the intelligence of the text.'

Since the entire Commentary of pp. 221-1044 in the first volumes of RSH has been totally omitted here, the numerous instances of 'See Commentary' in the original notes have all been altered: if the purpose of a particular reference could be summarized in a few words, that summary replaces the two-word remark; otherwise a specific page reference to $\mathrm{RSH}$ is the replacement. 
In general, it should be noted that the here-omitted Commentary, and the 374 endnotes to the original Introduction (on pp. lxxxiii-cxiii) contain encyclopedic information about nearly every detail of the Secret History text, and Mongol language and culture in the early days. Readers may also want to consult a few other publications that could improve their understanding of the text and its subject matter. A few outstanding works may be mentioned here, with bibliographic information provided after the two indexes below: one article by Owen Lattimore in the Scientific American (1963), one by Joseph Fletcher in HJAS (1986), and either the new edition of John Man's Genghis Khan; Life, Death and Resurrection, or that same writer's The Mongol Empire.

\section{Endnotes}

${ }^{1}$ The quotations here and above are from RSH xxv-xxvi.

${ }^{2} \mathrm{RSH}$ xxvi; the following paragraph quotes from xxvii-xxviii.

${ }^{3}$ See RSH xxix-xxxiii, 2.1038-44, 3.138 (this last for bičiðü da'usba, lit. 'finished writing', as 'composed' rather than simply 'copied').

${ }^{4}$ See R-08, esp. p. 152. Note that 'the Year of the Rat' is again mentioned in $\$ 269$ of the Secret History, this time as the year of Ögödei's enthronement; so there, as well as in the colophon, it is clearly an error - 'no doubt due to careless editing' - for the Year of the Ox (RSH lxxxviii, n. 99; cf. R-08.151-52).

${ }^{5}$ Cf. RSH 2.923, 984-85. The intervocalic apostrophe in such names and other Mongolian forms may be considered simply a marker of hiatus between vowels, the second of which was long. Cf. notes 26 and 27 below.

${ }^{6} \mathrm{R}-08.174$, et passim.

${ }^{7}$ R-08.175.

${ }^{8}$ For this new title, see RSH 1.457-60.

${ }^{9}$ For details on this man, see RSH xxxvi-xl, 3.2-3, 3.16, and esp. SH $\S \S 135,203$; for other matters concerning the authorship of the Secret History, see xxxiv-xl.

${ }^{10} \mathrm{Cf}$. RSH 3.5: one reader wrote the author in 2011: 'you and I are in total agreement that if he did not play a direct role in writing the $S[$ ecret $] H[$ istory], Ögödei managed the whole project, although the text was tampered with later.' With this statement the present editor 
is in complete agreement. For what evidence there is, see R-08 (esp. pp. 160-62 and 174ff), RSH 3.3-5 (where it is pointed out that in $\$ 269$ the narrator refers to 'my father the Qan'; and that a remark of the narrator's in \$229 is later put into Ögödei's mouth, in §278), and further mention in RSH 3.16, 123, 136-37.

${ }^{11} \mathrm{RSH}$ xli, with discussion on xl-liii.

${ }^{12}$ This and the two following quotations are taken from RSH xlii-xliii.

${ }^{13} \mathrm{RSH}$ xlii-xliii.

${ }^{14} \mathrm{RSH}$ lxxxviii, n. 95, with reference to R-83.274 and 278, n. 10. Cf. also RSH 1.222-23.

${ }^{15} \mathrm{RSH}$ 3.6.

${ }^{16} \mathrm{R}-83.274$.

${ }^{17} \mathrm{RSH}$ xliii.

${ }^{18}$ For details on this document, see RSH liv-lix, 3.13-14. The manuscript is (lvi) 'a mediocre late- $17^{\text {th }}$ or early $18^{\text {th }}$ century copy of [some] lost original, containing numerous misprints and faults.' The text was found to contain much of the Secret History, some of it 'in either a "mutilated" or "enlarged" form' (RSH lvii, and especially notes 93 and 177 on lxxxvii, xcvi), but a great deal is identical with the text known from Chinese sources. Note that the Altan Tobči does not include the supplementary chapters, nor what are now $\S \S 176-208$.

${ }^{19} \mathrm{RSH}$ xliv-xlv. That the scholars involved had access to a Uighur script copy is 'shown by numerous idiosyncrasies of the Chinese transcription' (1xxxix, n. 109, with further references).

${ }^{20} \mathrm{RSH}$ xlv for this and the two following quotations. And generally xliv-xlviii for the changes made at this period.

${ }^{21}$ During at least the final three decades of Mongol rule of China it was expressly against the law to help Chinese learn Mongolian (Hung51.458, citing Yüan shih 39.8b for 1337).

${ }^{22}$ This quotation and all others in the remainder of this section are from RSH xlv-lii.

${ }^{23} \mathrm{KCI}$ separates parts of a proper name by underlined space, and precedes nominal suffixes by a hyphen, verbal ones by an equals sign.

${ }^{24}$ This is mentioned in RSH only in note 119 on page xci (referred to on xlvii). The ideas expressed just below are mine (Ed.)

${ }^{25}$ Actually the Mongolian word-order emphasizes the name, so perhaps '[it was] Batačiqan [who] was born [to them].'

${ }^{26} \mathrm{RSH}$ lxv, with additional remarks in RSH 3.7-8. The uncertainty here is simply that we don't have early texts that might help us determine 
exactly when each of these sound changes took place. The dropping of certain Proto-Mongolian intervocalic consonants before an original long vowel (their position thereafter represented by $g$ or $\gamma$ in the Uighur script used for Mongolian, and by an apostrophe in romanization of our Chinese-based text; but by $y$ after $i$ ) may well have started before the birth of Činggis Qan. Only sometime later how many decades we cannot know - did identical vowels in sequence start to merge into one secondary long vowel. And the assimilation of second-syllable $a$ to a first-syllable rounded vowel seems to have been a relatively late change. Variant spellings in the Secret History text seriously complicate our understanding of all such changes.

${ }^{27}$ Nonetheless, when it comes to pronouncing the Mongol names (and a few other terms) occurring in the translation below, each reader will need to anglicize these in whatever way seems most convenient. The symbols $\check{c}, \breve{J}, \check{s}$, (upper and lower case) in Mongolian forms may be pronounced like the initial sounds in English cheap, Jeep, sheep. The letter $q / Q$ may be pronounced as the $c$ of coat, but was actually ambiguous, representing something like either back $[\mathrm{k}]$ or back $[\mathrm{g}]$ in the actual language, possibly as in coat and goat. (E.g., $\mathrm{SH}$ qara 'black' and qar 'hand' are distinguished in the Uighur script as mo. qara and $\gamma a r$.) The sequence $n g$ is always to be pronounced as in singing or hanger (but not anger or singe). The vowels of Mongolian are more problematic. Umlauted $\ddot{o}$ and $\ddot{u}$ will present little problem for multi-lingual readers, but no simple and general rules can be specified. An apostrophe simply shows syllable division.

${ }^{28} \mathrm{RSH}$ 1xi-lxii for this and the quotations just below.

${ }^{29} \mathrm{RSH}$ lxii-lxvii for the quotations here and in the next three paragraphs.

${ }^{30}$ I.e., J̌ebe, Qubilai, J̌elme, Sübe'etei; and Bo'orču, Muqali, Boroqul, Čila'un.

${ }^{31}$ RSH ci, n. 241; then 1xix and ci, n. 242 for those following.

${ }^{32}$ See RSH bibliographical listings (2.1124-84) under the abbreviations $\mathrm{H}$, Ha (cf. HH), Ko, Shi; likewise $\mathrm{Na}^{1,2}, \mathrm{~Pa}, \mathrm{Pe}, \mathrm{Te}$ (for Naka, Palladiǔ, Pelliot, Temir).

${ }^{33}$ RSH lxxvi.

${ }^{34}$ See RSH cv-cvi, note 312, which includes an explanation for this long delay. (Prof. Cleaves was extraordinarily kind to the present editor in lending him copies of type-set proof pages for the first few chapters of his nascent Secret History translation in the fall of 1953; without those, completion of my dissertation on the Secret History in 1955 would have been impossible.)

${ }^{35}$ RSH lxxix-1xxx. 



\section{THE SECRET HISTORY OF THE MONGOLS}

\section{CHAPTER ONE}

The origins of Činggis Qa'an.

At the beginning there was a blue-grey wolf, born with his destiny ordained by Heaven Above. His wife was a fallow doe. They came crossing the Tenggis. ${ }^{1}$ After they had settled at the source of the Onan River on Mount Burqan Qaldun, Batačiqan was born to them.

The son of Batačiqan was Tamača; the son of Tamača, Qoričar Mergen; the son of Qoričar Mergen, A'uǰam Boro'ul; the son of A'ujam Boro'ul, Sali Qača'u; the son of Sali Qača'u, Yeke Nidün; the son of Yeke Nidün, Sem Soči; the son of Sem Soči, Qarču.

The son of Qarču, Borjigidai Mergen, had as wife Mongqolǰn Qo'a. The son of Borjigidai Mergen, Toroqolǰin Bayan, had a wife named Boroqčin Qo'a, a young $\mathrm{lad}^{2}$ named Boroldai Suyalbi, and two fine geldings, Dayir and Boro. ${ }^{3}$ Toroqolǰin had two sons, Du'a Soqor and Dobun Mergen.

4 Du'a Soqor had a single eye in the middle of his forehead: with it he could see for a distance of three stages. ${ }^{4}$

One day Du'a Soqor went up Burqan Qaldun with his younger brother Dobun Mergen. Du'a Soqor looked out from the top of Burqan Qaldun, and, as he did so, ${ }^{5}$ he saw in the distance a band of people on the move who, following the course ${ }^{6}$ of the Tünggelik Stream, were coming

6 that way. He said, 'Among those people on the move who are coming this way, there is a fine girl in the front seat of

${ }^{1}$ Lit., 'the Sea' or (fig.) 'a large body of water' such as a great lake, possibly the Baikal.

2 I.e., a young manservant.

3 I.e., 'Dusky' and 'Grey.'

4 A 'stage' (ne 'üri) is the distance between two nomadic camps.

5 Lit., 'when he looked.'

${ }^{6}$ I.e., downstream. 
a black covered cart. ${ }^{1}$ If she has not been given to another man, we shall ask her for you, my younger brother Dobun Mergen!' So saying, he sent his younger brother Dobun Mergen to have a look.

When Dobun Mergen reached those people, he saw that she was indeed a beautiful and charming girl, and of excellent reputation. Her name was Alan Qo'a and she had not yet been given to any other man.

As for that band of people, the matter stood thus. The daughter of Barqudai Mergen, lord of the Köl Barqujin Lowland, was a girl named Barqujin Qo'a, and she had been given in marriage to Qorilartai Mergen, a chief of the Qori Tumat. At Ariq Usun, ${ }^{2}$ in the land of the Qori Tumat, that girl named Alan Qo'a was born to Barqujin Qo'a, wife of Qorilartai Mergen.

As in their land the Qori Tumat had imposed bans on one another's sable, squirrel and wild game ${ }^{3}$ hunting grounds, and mutual relations were bad as a result, Qorilartai Mergen separated from the Qori Tumat and took the clan name Qorilar. Saying that the land of Burqan Qaldun was good, and that it was suitable for game hunting, he was now moving into the territory of the Uriangqai Burqan Bosqaqsan and Šinči Bayan, lords of Burqan Qaldun. ${ }^{4}$

This is how Dobun Mergen asked there and then for Alan Qo'a, daughter of Qorilartai Mergen of the Qori Tumat born at Ariq Usun, and how he took her as his wife.

10 After Alan Qo'a had come to Dobun Mergen, she bore him two sons who were named Bügünütei and Belgünütei.

11 Du'a Soqor, his elder brother, had four sons. Before long, the elder brother Du'a Soqor died. After Du'a Soqor's death his four sons no longer regarded their uncle

1 I.e., a cart covered with black felt.

2 I.e., 'Clear Water (= River or Spring).'

3 I.e., mainly deer, antelopes and wild goats.

${ }^{4}$ Translation uncertain. 'Burqan Bosqaqsan' may actually be a designation (lit., 'Who has erected the Burqan [? image]') of Šinči Bayan, and 'lords' (e jet) an honorific plural. See RSH 1.250-54. 
Dobun Mergen as a member of the family but, looking down on him, they left him and moved away. They took the clan name Dörben and became the Dörben tribe.

After that, one day Dobun Mergen went out hunting on the Toqočaq Heights. ${ }^{1}$ In the forest he met a man of the Uriangqai tribe who had killed a three-year-old deer and was roasting its ribs and entrails. Dobun Mergen

13 said, 'Friend, share the quarry!'2 'I will give it to you,' said the man, and keeping for himself the main portion of the animal which has the lungs, ${ }^{3}$ and the skin, he gave all the meat of the three-year-old deer to Dobun Mergen.

14 Dobun Mergen went on, carrying the three-year-old deer on the back of his horse. On the way he met a poor man on foot who was leading his son by the hand.

15 Dobun Mergen asked him, 'To which clan do you belong?' The man said, 'I am a man of the Ma'aliq Baya'ut, and I am in desperate straits. Give me some of the meat of that animal and I will give you this child of

16 mine.' At these words Dobun Mergen cut off one thigh of the three-year-old deer and gave it to him, and he took the child to be a servant in his house.

17 Before long, Dobun Mergen died. After his death, Alan Qo'a, although she had no husband, bore three sons who were named Buqu Qatagi, Buqatu Salǰi and Bodončar Mungqaq. 4

18 Belgünütei and Bügünütei, the two sons born earlier to Dobun Mergen, said to each other, behind the back of their mother Alan Qo'a, 'Although this mother of ours is without brothers-in-law and male relatives, and without a husband, she has borne these three sons. In the house there is only the man of the Ma'aliq Baya'ut. Surely these three sons are his.' Their mother Alan Qo'a knew what they had been saying to each other behind her back. ${ }^{5}$

One day in spring, while she was cooking some dried

\footnotetext{
Or 'Hills,'

2 Lit., 'Friend, the roast!'

3 I.e., the head, trachea, lungs and heart.

4 I.e., 'Bodončar the Fool (or Simpleton).'

5 Lit., 'behind the back of their mother.'
} 
lamb, she had her five sons Belgünütei, Bügünütei, Buqu Qatagi, Buqatu Salǰi and Bodončar Mungqaq sit in a row. She gave an arrow-shaft to each of them and said, 'Break it!' One by one they immediately broke the single arrowshafts and threw them away. Then she tied five arrowshafts into a bundle and gave it to them saying, 'Break it!' The five sons each took the five bound arrow-shafts in turn, but they were unable to break them.

20 Then their mother Alan Qo'a said, 'You, my sons Belgünütei and Bügünütei, are suspicious of me and said to each other, "These three sons that she has borne, of whom, of what clan, are they the sons?" And it is right for

21 you to be suspicious. Every night, a resplendent yellow man entered by the light of the smoke-hole or the door top of the tent, he rubbed my belly and his radiance penetrated my womb. When he departed, he crept out on a moonbeam or a ray of sun in the guise of a yellow dog.

How can you speak so rashly?

When one understands that, the sign is clear:

They are the sons of Heaven.

How can you speak, comparing them

To ordinary black-headed men?

When they become the rulers of all,

Then the common people will understand!'

22 Further, Alan Qo'a addressed these words of admonition to her five sons: 'You, my five sons, were born of one womb. If, like the five arrow-shafts just now, each of you keeps to himself, then, like those single arrow-shafts, anybody will easily break you. If, like the bound arrowshafts, you remain together and of one mind, how can anyone deal with you so easily?' Some time went by and their mother Alan Qo'a died.

23 After the death of their mother Alan Qo'a, the five brothers divided the livestock ${ }^{1}$ among themselves. Belgünütei, Bügünütei, Buqu Qatagi and Buqatu Salǰ all took their share; to Bodončar no share was given, for they said that he was a fool and a half-wit, and they did not regard him as one of the family.

1 I.e., the family property. 
24 Bodončar, seeing that he was no longer counted as one of the family, said, 'Why should I stay here?' He got on a white horse with a black sore back and a mangy tail. ${ }^{1}$ 'If I die, I die; if I live, I live!'² he said and left riding fast downstream along the Onan River. He went on and when he reached Baljun $\mathrm{Aral}^{3}$ he built a grass hut ${ }^{4}$ and made his home there.

25 While he was living there, he once saw a grey female hawk eating a black grouse that it had caught. He made a snare with the hair of his white horse with the black sore back and mangy tail, caught the hawk and reared it.

26 When he had nothing to eat, he stalked the wild game which wolves had penned in on the cliffs. He shot and killed the game, and fed on it together with the hawk; they also gathered up and ate the food left over by the wolves. And so, feeding his own gullet and his hawk, he got through that year. ${ }^{5}$

27 When spring came and the ducks began to arrive, he starved his hawk and let it loose. The ducks and wild geese which the hawk had caught he placed all about, so that

Every tree stump reeked with their stench,

Every dead tree with their foul smell.

28 From the northern side of Mount Düyiren, a band of people on the move came following the course of the Tünggelik Stream. After he had loosed his hawk in the daytime, Bodončar used to go to those people and drink kumis with them: at night he returned to his grass hut to sleep.

29 Those people asked Bodončar for his hawk, but he would not give it to them. Thus they got along together without the people asking Bodončar whose son he was

1 Lit., 'with a black stripe along the backbone, mid-back saddlesores, and a hairless tail.'

2 Or: 'If he dies, I will die; if he lives, I will live!' See RSH 1.269, 3.51-53.

3 Aral means 'island' as well as 'peninsula.'

4 Lit., 'a grass hut-tent.'

5 I.e., through that winter. 
and to which clan he belonged, and without Bodončar for his part asking them what people they were.

30 His elder brother Buqu Qatagi, saying that the younger brother Bodončar Mungqaq had left following the course of this Onan River, came in search of him. He asked those people who had moved down along the Tünggelik Stream about such-and-such a man with such-

31 and-such a horse. The people said, 'There is a man and a horse similar to those you ask about. He also has a hawk. Every day he comes to us, drinks kumis, then leaves. Where he spends the night no one really knows; but when the wind blows from the north-west, the fluff and feathers of the ducks and geese caught by his hawk are scattered and fly over here like swirling snow. He must live nearby. Now is about the time of his coming. Wait a little!'

Within a short time a man came up along the Tünggelik Stream. When he arrived, it was indeed Bodončar. As soon as his elder brother Buqu Qatagi saw him, he recognized him; he led him away and set out, trotting off upstream along the Onan River.

33 Bodončar, who was trotting behind his elder brother Buqu Qatagi, said on the way, 'Elder brother, elder brother, it is right for a body to have a head, and for a coat to have a collar. ${ }^{, 1}$ His elder brother Buqu Qatagi did not attach any importance to these words of his. When he

34 repeated the same words, his elder brother again ignored them and did not answer. Further along, Bodončar once more uttered the same words, to which his elder brother said, 'What kind of words are those you have just

35 been repeating?' Then Bodončar said, 'These people of a short while ago who are staying on the Tünggelik Stream make no distinction between great and small, bad and good, high and mean: ${ }^{2}$ they are all equal. They are people easy to capture. Let us raid them!' His elder

${ }^{1}$ A saying, the meaning of which is that a group of people must have a chief to ensure proper leadership.

2 Lit., 'head and hoof.' 
36 brother then said, 'Right. If this is so, as soon as we reach home let us consult with our brothers and raid those people!'

37 When they reached home, older and younger brothers discussed the matter together, then set out on their horses. They had Bodončar himself ride ahead as a scout.

Bodončar, as he was riding ahead reconnoitring, captured a woman who was in the middle of her pregnancy. He asked her, 'To which clan do you belong?' The woman said, 'I am an Adangqan Uriangqai of the Jarči'ut clan.'

The five brothers together robbed those people, and in this way got enough livestock, people to serve them, and a place to live.

The woman who was mid-way through pregnancy came to Bodončar and gave birth to a son. As he was the son of strangers, they named him Jajiradai. He was the ancestor of the Jadaran. ${ }^{1}$ The son of that Jadaradai ${ }^{2}$ was named Tügü'üdei. The son of Tügü'üdei was Büri Bulčiru. The son of Büri Bulčiru was Qara Qada'an. The son of Qara Qada'an was Jamuqa. These took the clan name Jadaran.

41 That woman also gave birth to a son by Bodončar. Since she was a captured woman, her son was named Ba'aridai. He was the ancestor of the Ba'arin. ${ }^{3}$ The son of Ba'aridai was Čiduqul Bökö, who had many wives and whose sons were born in great profusion. ${ }^{4}$ These took the clan name Menen Ba'arin.

42 From Belgünütei stemmed the Belgünüt clan; from Bügünütei, the Bügünüt; from Buqu Qatagi, the Qatagin; from Buqatu Salǰi, the Saly̌i'ut; from Bodončar, the Borjigin.

43 From the wife that Bodončar himself had taken was born a son named Barim Ši'iratu Qabiči. Bodončar also

${ }^{1}$ These personal and clan names are explained, in popular etymology, from the word jat ( ̌ad) meaning 'foreign.'

${ }^{2}$ The 'J̌adaradai' or 'man of the Jadaran clan' is, of course, Jajuiradai.

${ }^{3}$ Bari-means 'to seize, capture, abduct' - another example of popular etymology to explain a clan name.

${ }^{4}$ Mene metü-hence the association with the clan name Menen. 
took as concubine a housemaid of Qabiči Ba'atur's mother, who had come as dowry. She had a son by him named J̌e'üredei. At first J̌e'üredei could take part in the Jügeli sacrifice in which meat is hung on a pole and offer-

44 ed to Heaven. After Bodončar's death he was excluded from it ${ }^{1}$ because - so they said - the Adangqa Uriangqai $\operatorname{man}^{2}$ was constantly in the house and J̌e'üredei must be his son. They made him take the clan name J̌e'üreyit and he became the ancestor of the Je'üret.

45 The son of Qabiči Ba'atur was Menen Tudun. The sons of Menen Tudun were Qači Külük, Qačin, Qači'u, Qačula, Qači'un, Qaraldai and Način Ba'atur.

The son of Qači Külük, Qaidu, was born of Mother Nomolun. The son of Qačin was named Noyagidai; because, by nature, he liked to act as a chief, his descendants took the clan name Noyakin. The son of Qači'u was named Barulatai. He had a big body and was a voracious eater; therefore, his descendants took the clan name Barulas. As the sons of Qačula were also voracious eaters, they were named Yeke Barula and Üčügen Barula; ${ }^{3}$ they too had to take the clan name Barulas and it is these who became the Erdemtü Barula, the Tödö'en Barula and the other Barulas. The sons of Qaraldai did not observe seniority when they cooked ${ }^{4}$ porridge; therefore, their descendants took the clan name Buda'at. The son of Qači'un was named Adarkidai; because he spread slanders among his elder and younger brothers, his descendants took the clan name Adargin. The sons of Način Ba'atur were named Uru'udai and Mangqutai; they took the clan names Uru'ut and Mangqut. Those sons of Način Ba'atur who were borne by the wife he himself had taken, were named Šiju'udai and Doqoladai.

47 The sons of Qaidu were Bai Šingqor Doqšin, Čaraqai Lingqu and Čauǰin Örtegei. The son of Bai Šingqor Doqšin was Tumbinai Sečen. The son of Čaraqai Lingqu

${ }^{1}$ Lit., 'they excluded that J̌e'üredei from the J̆̈̈gefi.'

${ }^{2}$ Bodončar's son by his Adangqa Uriangqai wife, i.e. J̌ăjiradai.

3 I.e., 'Big Barula' and 'Small Barula.'

${ }^{4}$ Lit., 'stirred.' 
was Senggüm Bilge; his descendants, [beginning with] Senggüm Bilge's son Ambaqai [Qa'an], took the clan name Tayiči'ut. From a sister-in-law of Čaraqai Lingqu who became his wife was born a son named Besütei. His descendants took the clan name Besüt. The sons of Caujin Örtegei and their descendants took the clan names Oronar, Qongqotan, Arulat, Sönit, Qabturqas and Geniges.

The sons of Tumbinai Sečen were Qabul Qa'an and Sem Sečüle. ${ }^{1}$ The son of Sem Sečüle was Bültečü Ba'atur. ${ }^{1}$ Qabul Qa'an's sons were seven. The eldest was Ökin Barqaq; then came Bartan Ba'atur, Qutuqtu Mönggür, Qutula Qa'an, Qulan, Qada'an and Tödö'en Otčigin. These were the seven.

The son of Ökin Barqaq was Qutuqtu Yürki. ${ }^{1}$ Qutuqtu Yürki's sons were Seče Beki ${ }^{2}$ and Taiču. These took the clan name Yürki.

50 These four were the sons of Bartan Ba'atur: Mönggetü Kiyan, Nekün Taiši, Yisügei Ba'atur and Dāritai Otčigin. The son of Qutuqtu Mönggür was Büri Bökö. It was he who, with his sword, split open Belgütei's shoulder at the feast held in the forest by the Onan. ${ }^{3}$

51 The sons of Qutula Qa'an were J̌či, Girma'u and Altan. The son of Qulan Ba'atur was Yeke Čeren. He was the master of the two freemen Badai and Kišiliq. ${ }^{4}$ Both Qada'an and Tödö'en were without issue.

52 Qabul Qa'an ruled over all the Mongols. After Qabul Qa'an, although he had seven sons, Ambaqai Qa'an, the son of Senggüm Bilge, became the ruler of all the Mongols by Qabul Qa'an's will.

53 Ambaqai Qa'an gave his daughter as wife to the Ayiri'ut Buiru'ut Tatars who were living on the Urši'un River, between Lake Buyur and Lake Kölen. As he was taking his daughter to them in person, Ambaqai Qa'an was captured by Tatar Jüyin men. When they were on

1 The SH form Sem Sečüle is an error for Sam (or Sem?) Qačula(i). See RSH 1.287; and see the Names Index for the other names here.

${ }^{2}$ Written Sača Beki elsewhere in the text.

3 For this episode, see below, $§ 131$.

4 See below, $\$ 169$. 
their way to deliver him to the Altan Qa'an of the Kitat, Ambaqai Qa'an contrived to send a message using as messenger Balaqači, a man of the Besüt. He said to him, 'Speak to Qutula, the middle one of the seven sons of Qabul Qa'an, and of ${ }^{1}$ my ten sons speak to Qada'an Taiši.' And he sent saying, 'When you become ${ }^{2}$ qa'an of all and lord of the people, learn from my example and beware of taking your daughter in person to her betrothed. I have been seized by the Tatars.

Until the nails of your five fingers

Are ground down,

Until your ten fingers are worn away,

Strive to revenge me!'

54 At that time Yisügei Ba'atur was hunting with falcons along the Onan River when he met the Merkit Yeke Čiledï who was on his way home, taking with him a girl of the Olqunu'ut tribe to be his wife. Leaning forward to have a better look, he saw that she was an unusually beautiful young woman. He swiftly rode back to his tent, then returned leading his elder brother Nekün Taiši and his younger brother Dāritai Otčigin.

55 Čiledü became frightened at their coming. He had a fast dun mare; he struck his dun mare over the rump and galloped away over a hill. The three men rode after him. Čiledü rounded the spur of the hill and got back to his cart. There and then Lady Hö'elün said to him, 'Did you notice those three men? Their look is odd: they look as if they want to take your life. If only you are spared,

In the front seat of every cart

There are girls;

In every black cart

There are women.

If only you are spared, you will always find a girl or a woman like me. If her name is different, name her also Hö'elün. Save your life! Never forget to breathe my scent!' She took off her shirt and he, on horseback, seized it with his outstretched hand. By this time the three men

\footnotetext{
Lit., 'among.'

2 I.e., 'When either of you becomes...'
} 
had rounded the spur of the hill and were drawing near. Čiledï struck his fast dun mare on the rump, rode swiftly away and fled upstream along the Onan River.

The three men rode after him, chased him across seven hills and came back. Yisügei Ba'atur took the halter and guided the cart of Lady Hö'elün; his elder brother, Nekün Taiši, led the way, and his younger brother, Dāritai Otčigin, rode alongside the shaft of the cart. As they were proceeding, Lady Hö'elün said, 'My good lord ${ }^{1} \breve{C}_{\text {iledü is one }}$

Whose tuft has never blown

Against the wind,

Whose belly has never hungered

In the steppe.

But how is it now? How fares he, with his two plaits tossing sometimes over his back, sometimes over his breast, now forward, now backward?' So she spoke, and she went on wailing loudly

Until her voice stirred the waters of the Onan River,

Until it resounded throughout wood and valley.

Dāritai Otčigin, riding beside her, said,

'The one who held you in his arms

Has already crossed many ridges;

The one you bewail

Has already crossed many streams.

If you call him, and he looks back,

He will not see you;

If you look for his tracks,

His trail you will not find.

Be quiet!' - he warned her. Yisügei then took Lady Hö'elün into his tent. Such is the way in which Yisügei carried off Lady Hö'elün.

57 According to the message of Ambaqai Qa'an, which had nominated both Qada'an and Qutula, all the Mongols and Tayiči'ut gathered in the Qorqonaq Valley by the Onan and made Qutula qa'an. ${ }^{2}$ The Mongols rejoiced, and in their rejoicing they danced and feasted. After raising

1 Lit., 'elder brother', here a respectful term for 'husband.'

2 Read qan. See RSH 1.315. 
Qutula as qan, they danced around the Leafy Tree of Qorqonaq until there was

A ditch up to their waist,

And dust up to their knees.

58 When Qutula became qa'an, he and Qada'an Taiši moved against the Tatar people. They fought thirteen times with the Tatar chiefs Kötön Baraqa and J̌ali Buqa, but were unable

To take revenge,

To requite the wrong

for the slaying of Ambaqai Qa'an.

9 Then Yisügei Ba'atur captured the Tatars Temüjun Üge, Qori Buqa, and other Tatars. At that time Lady Hö'elün was pregnant, and as she was staying at Deli'ün Boldaq $^{1}$ by the Onan, it was right there that Činggis $\mathrm{Qa}^{\prime}$ an was born. At the time of his birth he was born clutching in his right hand a clot of blood the size of a knucklebone. Because he was born when the Tatar Temüjin Üge had been brought captive, for this very reason they gave him the name Temüjin.

60 Yisügei Ba'atur had these four sons born of Lady Hö'elün: Temüj̆in, Qasar, Qači'un and Temüge. One daughter was also born, named Temülün. When Temüj̆in was nine years old, J̌oči Qasar was seven, Qači'un Elči was five, Temüge Otčigin was three, and Temülün was still in the cradle. [From Yisügei Ba'atur's second wife, Mother Sučigil, ${ }^{2}$ Bekter and Belgütei were born.]

61 When Temüjin was nine years old, Yisügei Ba'atur set out to go to the Olqunu'ut people, relatives of Mother Hö'elün, taking Temüj̆in with him and saying, 'I shall ask his maternal uncles for a girl in marriage for him.' On the way, between Mount Čekčer and Mount Čiqurqu, he met Dei Sečen of the Onggirat.

62 Dei Sečen said, ' $\mathrm{u} u \mathrm{a}^{3}$ Yisügei, in whose direction are you going, coming this way?' Yisügei Ba'atur said, 'I have come here on my way to the Olqunu'ut people, the

${ }^{1}$ I.e., 'Spleen Hill.'

${ }^{2}$ Or Suǰigil.

${ }^{3}$ A term meaning 'relative by marriage.' 
maternal uncles of this my son, to ask for a girl in marriage for him.' Dei Sečen said, 'This son of yours is a boy

Who has fire in his eyes,

Who has light in his face.

'Quda Yisügei, I had a dream last night, I did. A white gerfalcon clasping both sun and moon in its claws flew down to me and perched on my hand. I told the people about this dream of mine, saying, "Before, when I looked, I could only see the sun and the moon from afar; now this gerfalcon has brought them to me and has perched on my hand. He has alighted, all white. Just what sort of good thing does this show?" I had my dream, quda Yisügei, just as you were coming here bringing your son. I had a dream of good omen. What kind of dream is it? The august spirit of you, Kiyat people, has come in my dream $^{1}$ and has announced your visit.

'With us, the Onggirat people, from old days,

To have the good looks of our granddaughters

And the beauty of our daughters is enough:

We do not strive for dominion.

For those of you who have become qa'an,

We have our daughters with beautiful cheeks

Ride on a large cart to which we harness

A black male camel.

We trot them off to the qa' an,

And seat them by him on the qatun's seat.

We do not strive for dominion, nor for people.

We lift our good-looking daughters,

We have them ride on a carriage with front seat;

We harness a dark male camel,

We lead them off to the qa'an,

And seat them on the throne, at his side.

From old days, the Onggirat people

Have the qatuns as shields,

Have their daughters as intercessors.

We live thanks to the good looks

Of our granddaughters

1 I.e., as an omen of good fortune for the Onggirat people. 
And the beauty of our daughters.

With our boys, when they seek a bride,

One ${ }^{1}$ looks at the wealth of our camp;

With our girls, when they are sought as brides,

$\mathrm{One}^{2}$ considers only their beauty.

Quda Yisügei, let us go to my tent. My daughter is still small, take a look at her, quda!' So said Dei Sečen, and having led him to his tent he made him dismount.

When Yisügei saw his daughter, he saw a girl

Who had light in her face,

Who had fire in her eyes.

He was pleased with her. She was ten years old, one year older than Temüjin, and her name was Börte. Yisügei spent the night there, and the following morning, when he requested his daughter for Temü̈̌in, Dei Sečen said, 'If I gave her away after much asking on your part, you would respect me; if I gave her away without much asking, you would despise me. But the fate of a girl is not to grow old in the family in which she was born. I will give you my daughter, and you, for your part, leave your son here as my son-in-law.' So they both agreed and Yisügei Ba'atur said, 'I will leave my son as your son-in-law, but my son is afraid of dogs. Quda, don't let him be frightened by dogs!' Then he gave him his spare horse as a pledge and went off, leaving Temüjuin as his son-in-law.

67 On the way back, Yisügei Ba'atur met some Tatars who were having a feast in the Šira $\mathrm{Ke}^{\prime} \mathrm{er}^{3}$ by Mount Čekčer. As he was thirsty, he got off his horse and joined them at the feast. But those Tatars recognized him: 'Yisügei the Kiyan has come,' they said, and remembered their grievance for his former raid upon them. With the secret intent to harm, they gave him poison ${ }^{4}$ mixing it with his food. On the way back, Yisügei Ba'atur felt ill. He

1 I.e., the family of the bride.

2 I.e., the family of the bridegroom.

3 I.e., 'Yellow Steppe (or Plain).'

${ }^{4}$ Or, possibly, 'they grievously injured him' - by mixing poison with his food. 
went on, and when after three days ${ }^{1}$ he reached his tent, 68 being in a bad way, he ${ }^{2}$ said, 'I feel sick within me. Who is at hand?' When they told him that Mönglik, the son of Old Čaraqa of the Qongqotat, was close by, he called him, made him come and said to him, 'Mönglik my boy, I have young children. I left my son Temüj̆in to be a son-in-law and, as I was coming back, I was secretly harmed by Tatar people on the way. I feel sick within me. You take care of your younger brothers, ${ }^{3}$ the little ones that I leave behind, and of your widowed elder sister-inlaw. ${ }^{3}$ Go quickly and bring back my son Temüjin, Mönglik my boy!' He spoke and passed away.

${ }^{1}$ Lit., 'three days and nights.'

${ }^{2}$ Lit., 'Yisügei Ba'atur.'

${ }^{3}$ The 'younger brothers' and 'elder sister-in-law' here are figurative terms, not to be taken literally. See RSH 1.340, and cf. $\$ 272$ below. 


\section{THE SECRET HISTORY OF THE MONGOLS}

\section{CHAPTER TWO}

Heeding the words of Yisügei Ba'atur, Mönglik went and said to Dei Sečen, 'Elder brother Yisügei thinks constantly of Temüjin, his heart is aching. I came to get Temüjuin.' Dei Sečen said, 'If my quda is longing for his son, let him go. But after he has seen him let him quickly come back.' And so Father Mönglik brought Temüjü back with him.

70 That spring, when Örbei and Soqatai, the wives of Ambaqai Qa'an, performed the Qajaru Inerü sacrifice to the ancestors, Lady Hö'elün also went, but as she arrived late she was left out of the sacrificial meal. Lady Hö'elün said to Örbei and Soqatai, 'You say to yourselves that Yisügei Ba'atur is dead, and as my sons are not grown yet, you deprive me of the share of the offerings to the ancestors, and of the sacrificial meat and drink that have been left over. Isn't this so? You have come to the point of eating under my very eyes without asking me to partake of the food, and of breaking camp without so much as awakening me!'

At these words the wives Örbei and Soqatai said,

'You are one for whom the rule holds

Not to be called and given food;

You are one for whom the custom holds

To eat if she chances upon food;

You are one for whom the rule holds

Not to be invited and given food;

You are one for whom the custom holds

To eat if food comes by her.

Is it because you say to yourself that Ambaqai Qa'an is dead, that we are being spoken to in this way, even by one

72 like you, Hö'elün? The best scheme for you, Tayiči'ut

${ }^{1}$ I.e., 'You would leave me out of everything.' 
people, is: Leave these, mothers and children, in the camp and move on without taking them along!'

So they spoke, and the following day Tarqutai Kiriltuq of the Tayiči'ut, Tödö'en Girte and the other Tayiči'ut began to move downstream along the Onan River. As they set out, leaving behind Lady Hö'elün, the mothers and the children, Old Čaraqa of the Qongqotat went after them and tried to stop them, but Tödö'en Girte said,

'The deep water has dried up,

The shining stone is shattered."

With this he moved off. Saying, 'Why do you hinder us?', Tödö'en Girte from behind speared Old Čaraqa along the spine.

73 Old Čaraqa returned to his tent wounded, and was lying in great distress when Temüjin went to see him. Then Old Čaraqa of the Qongqotat said, 'The people gathered by your good ${ }^{2}$ father, the people of all of us, they have taken with them and moved away. When I tried to stop them, this is how I was treated.' At that, Temüjin wept and went out.

After the Tayiči'ut had left Lady Hö'elün behind and moved away, she held the standard and, riding off all on her own, brought back half the people. But even those people who were brought back did not stay, and they too moved off following the Tayiči'ut.

74 The Tayiči'ut kinsmen ${ }^{3}$ had moved away, leaving the widowed Lady Hö'elün with her small sons, the mothers and the children, in the camp, but

Lady Hö'elün was born

A clever woman

And she nourished her small sons thus:

Pulling firmly her tall hat

Over her head,

Tying tightly her belt

To shorten her skirt,

1 I.e., 'The situation is beyond repair - it's all over.'

2 I.e., 'late.'

3 Lit., 'brothers': Tarqutai and his brothers were distant cousins of Temüjin's father. See RSH 1.351. 
Along the Onan River, Running up and down, She gathered crab apples and bird cherries, Day and night she fed Their hungry gullets.

Born brave, the noble mother ${ }^{1}$

Nourished her sons who were favoured With Heaven's good fortune.

With a pointed stick from a spruce She dug for roots of the great burnet, And for those of the silverweed, And so she provided them with food. The sons who were fed on wild garlic And on wild onion by the noble mother, In time became rulers;

The sons who were fed on wild lily bulbs By the high-minded, noble mother

Became lawful and wise.

The hungry, nagging sons

Who were fed on wild leek

And on wild onion by the beautiful lady, Became handsome $^{2}$ and good, And grew up into fine men Truly valiant and bold.

Saying to each other,

'Let us feed our mother!'

They sat on the bank of Mother Onan, They prepared their hooks and fished Mean and paltry ${ }^{3}$ fish; Bending needle into hook, They fished for salmon and grayling. They made seines and dragnets, And caught fingerlings: Then, with grateful heart, They fed their mother.

1 Lit., 'the lady mother.'

2 Or 'full of vigour.' The meaning of the Mongolian term is not clear.

${ }^{3}$ Lit., 'Maimed and injured.' 
One day while Temüjin, Qasar, Bekter and Belgütei were sitting together on the river bank angling, a shiny dace came onto the line. Bekter and Belgütei snatched it away from Temǚ̆in and Qasar. Temüj̆in and Qasar came home and said to the noble mother, 'A shiny dace bit our hook, but it was snatched away from us by our brothers Bekter and Belgütei.' Thereupon, the noble mother said, 'Why be so malicious? [Stop it!] Why do you, older brothers and younger brothers, behave in this way to each other? Just when

We have no friend but our shadow,

We have no whip but our horse's tail,

and when we ask ourselves how to take vengeance for the outrage committed by our Tayiči'ut kinsmen, how can you be at odds with each other, like the five sons of Mother Alan ${ }^{1}$ of old? Stop it!'

77 Thereupon, Temüjin and Qasar, displeased with their mother's words, said, 'Once, lately, a lark we shot with a knob-headed arrow, ${ }^{2}$ they snatched it away from us, just like that. And now, again, they have snatched something the same way. How can we live together with them?' So saying they flung open the felt door and went out.

At that time Bekter was sitting on a hillock, guarding their nine horses, the light-bay geldings. Temüjin, hiding from behind, and Qasar, hiding in front, were approaching and about to draw out their arrows when Bekter saw them and said, 'Just when we cannot put up with the outrage of our Tayiči'ut kinsmen and ask ourselves who shall be able to take vengeance on them, why do you regard me as a lash in the eye, a thorn in the mouth? When

We have no friend but our shadow,

We have no whip but our horse's tail,

how can you harbour such thoughts towards me? Anyway, do not destroy my hearth, pray do not make away with Belgütei!' So he said, and sat cross-legged, waiting for their arrows. Temijyin and Qasar, one from the front

${ }^{1}$ I.e., Alan Qo'a; see above, $\S \S 18-22$.

${ }^{2}$ Qodoli, i.e. an arrow with a round, blunt head. See RSH 1.366 for details. 
and one from the rear, shot at him at close range and went away.

78 When they came back and entered the tent, the noble mother understood everything from the looks of her two sons and said, 'You who have destroyed life!

From the warmth of my womb,

When he broke forth fiercely,

This one was born

Clutching a black clot of blood.

Like a Qasar ${ }^{1}$ dog snapping at its own afterbirth;

Like a panther assailing a cliff;

Like a lion uncontrollable in its rage;

Like a dragon-snake swallowing its prey alive;

Like a gerfalcon that attacks its own shadow;

Like a pike swallowing in silence;

Like a camel in rut biting its foal's heel;

Like a wolf stalking its prey under cover of a blizzard;

Like a mandarin duck eating its chicks

When it cannot manage them;

Like a jackal ganging up with its pack

When one threatens its den;

Like a tiger never hesitant

When seizing its prey;

Like a brach attacking wildly,

You have destroyed!

Just when

We have no friend but our shadow,

We have no whip but our horse's tail,

and when, unable to put up with the outrage of our Tayiči'ut kinsmen, we ask ourselves who shall take vengeance on them, you behave [in this way] to each other, saying that you cannot live together!' Thus she spoke, and

Citing old sayings,

Quoting ancient words, mightily reviled her sons.

1 I.e., Khazar. 
Soon after this, Tarqutai Kiriltuq of the Tayiči'ut came at the head of his bodyguard and said,

'The little rascals have shed their down,

The snotty ones have grown up!'

Frightened, the mothers and the older and younger brothers barricaded themselves in the thick forest. Belgütei tore out trees and, hauling them up together, erected a palisade. While Qasar exchanged arrow shots, Qači'un, Temüge and Temülün were thrust between clefts in the cliff.

They were battling in this fashion when the Tayiči'ut shouted, 'Send out your elder brother Temüjin; we have no need for the rest of you!' Upon this shouting, they put Temüj̆in on a horse and made him escape. The Tayiči'ut saw him fleeing into the forest and went in pursuit, but Temüjin managed to steal into a thicket on the Tergüne Heights. The Tayiči'ut could not get in, so they kept watch round about the thicket.

80 Temüjin spent three days and nights in the thicket, then he said, 'I will get out.' As he moved on leading his horse after him, his saddle worked itself loose, fell from the horse and was left behind. When he went back and looked, he saw that the saddle had loosened and remained behind even though the breast-strap was still attached and the saddle-girth was still fastened. He said, 'The saddlegirth could of course have loosened up, but how could the breast-strap also have worked itself loose? Is this a warning from Heaven?' He turned back and spent three more days and nights there.

When he started out again, a white rock the size of a tent fell at the opening of the thicket, blocking the opening. He said, 'Is this a warning from Heaven?' He turned back and spent three more days and nights there.

After having been already nine days and nights without food, he said, 'Why must I die so ignominiously? I will get out!' With his arrow-sharpening knife he cut the bushes - so thick that it was impossible to get out around that white rock, the size of a tent, which had fallen and blocked the opening; he let his horse slip through and came out of the thicket. But the Tayiči'ut were keeping 
watch: as soon as he emerged they seized him and took him away.

81 After having taken Temüj̆in away, Tarqutai Kiriltuq gave the order to his people that he should spend one night in each ayil ${ }^{1}$ in rotation. As this was happening, on the sixteenth of the first month of summer, the day of the Red Circle, ${ }^{2}$ the Tayiči'ut held a feast on the bank of the Onan. At sunset they dispersed. Temüjin had been brought to this feast by ${ }^{3}$ a weak young man. After the people at the feast had dispersed, Temüÿin pulled the leash of his cangue ${ }^{4}$ away from that weakling, hit him once on the head and ran away. Then, telling himself that if he lay down in the forest by the Onan he would be seen, he reclined on his back in the water's stream and, letting his cangue float with the current, he lay with only his face clear.

82 When the man who had let him escape called out in a loud voice, 'I let the prisoner escape!', the scattered Tayiči'ut gathered together again. In the moonlight, which was as bright as daylight, they searched the forest by the Onan.

Sorqan Šra of the Suldus happened to pass by and he saw Temüÿin lying in the stream. He said to him, 'It is just because you are so clever, and because

There is fire in your eyes,

There is light in your face,

that your Tayiči'ut kinsmen are so jealous. Lie just so; I shall not tell them.' And with these words he went off.

When the Tayiči'ut said, 'Let's go back and search once more!', Sorqan Šira said, 'Let's go back each on his own way and search, looking at the places which we have not yet looked at.' They agreed and made a search going back by the very same way.

As Sorqan Šira again passed by him, he said, 'Your

1 Ayil: a group of tents belonging to one family.

2 I.e., 'of the full moon.'

3 I.e., 'in the charge of.'

${ }^{4}$ Buqa'u: a heavy wooden board worn round the neck by prisoners. 
kinsmen are approaching, sharpening their teeth. ${ }^{1}$ Lie just so and be careful!' And with these words he went off.

83 When the Tayici'ut said, 'Let's go back and search once more', Sorqan Šira again spoke and said, 'Tayiči'ut princes, you have lost a whole man in a shining and bright day; how shall we find him now in the dark night? Let's go back each by his own way and search once more, looking at the places which we have not yet looked at, then let us disperse. Tomorrow we shall reassemble and look for him again. Where could that man go, with a cangue?' They agreed and went back searching.

As Sorqan Šira again passed by Temü ̌̌in, he said to him, 'We decided that we will go home after this search and look for you tomorrow. Now wait until we have completely dispersed, then go and look for your mother and younger brothers. If someone sees you, don't tell him you were seen and reveal that it was I who saw you!' And with these words he went off.

84 Temüjin waited until they had completely dispersed, then he thought to himself, 'The other day, when I was made to spend the night in each ayil in rotation, I spent one night in the tent of Sorqan Šira. His two sons, Čimbai and Čila'un, felt in their hearts very sorry for me, and seeing me at night they took my cangue, relieved me of it and enabled me to spend the night resting. Again now, when Sorqan Šra saw me, he passed by without telling anyone. Now those same people will surely save me.' So saying he went downstream along the Onan River looking for the tent of Sorqan Šira.

85 The sign by which one recognized the tent was that, after pouring out mare's milk, they used to churn their kumis all through the night until daybreak. As he went, listening for this sign, Temüyin heard the sound of the churner and arrived there. When he entered the tent, Sorqan Šra said, 'Didn't I tell you to go and look for your mother and younger brothers? Why did you come here?' But his two sons Čimbai and Čila'un said, 'When a sparrow-hawk causes a sparrow to take shelter into a

1 Lit., 'sharpening their mouths and teeth.' 
bush, the bush saves its life. How can you speak to him in this way, now that he has come to us?' And, displeased at their father's words, they smashed open Temüjin's cangue, burnt it in the fire and put him into a cart loaded with wool which was standing behind the tent. They entrusted him to the care of their younger sister called Qada'an, who was told not to say a word to a living person.

86 On the third day the Tayiči'ut said to each other that someone had probably hidden him. They said, 'Let us hold a search among ourselves', and began searching one another. They searched Sorqan Šira's tent, his carts, even under the beds. They climbed onto the cart loaded with wool which was standing behind the tent and pulled out the wool near the front opening. They were reaching the back of the cart when Sorqan Sira said, 'Anyway, in such heat, how could one stand it amidst the wool?' The searchers then stepped down and went away.

87 After the searchers had left, Sorqan Sira said, 'You nearly had me blown to the winds like hearth-ashes. ${ }^{1}$ Now go, look for your mother and younger brothers!' He set Temüyin on a tawny barren mare with a white mouth, cooked him a lamb fattened on the milk of two ewes and provided him with a small and a large leather bucket containing mare's milk. He did not give him either saddle or steel for striking fire, but gave him a bow and two arrows. Having thus provided for him, he sent him on his way. ${ }^{2}$

88 So Temüjin set out and reached the place where they had earlier built the palisade and barricaded themselves. Following some tracks in the grass upstream along the Onan River - the Kimurqa Stream flowing into it from the west - he followed the tracks up along this stream and came upon his own people who were staying at the time at the Qorčuqui Hill of the Beder Promontory by the Kimurqa Stream.

1 I.e., 'You nearly caused my ruin and that of my family.'

2 For Tarqutai's own version of Temüǰin's kidnapping, cf. below, $\S 149$. 
89 Once they were reunited there, they left and set up camp at Kökö Na'ur ${ }^{1}$ of Mount Qara Jirügen ${ }^{2}$ by the Senggür Stream, in the Gürelgü Mountains south of Burqan Qaldun. Here they stayed, killing marmots and field-mice for food.

90 One day some robbers came and stole the eight horses, the light-bay geldings, that were standing by the tent and made off with them before their very eyes. Temüjin and his brothers sighted the robbers, but being on foot fell behind.

Belgütei was then away marmot-hunting on $^{3}$ a shorttailed, short-haired chestnut horse. He arrived on foot in the evening after sunset, leading behind him the shorttailed, short-haired chestnut horse, which was so laden down with marmots that it staggered. When he was told that robbers had stolen the light-bay geldings, Belgütei said, 'I will go after them!' Qasar said, 'You cannot cope with them, I will go after them!' Temüjin said, 'Neither of you can cope with them, I will go after them!' Temüjin got on the short-haired chestnut horse and went off in pursuit of the light-bay geldings, following the tracks left in the grass.

He spent three days and nights tracking, and in the early morning of the fourth day he met on the way a brisk lad milking mares in a large herd of horses. When Temüyin inquired about the light-bay geldings, the lad said, 'This morning, before sunrise, eight horses - lightbay geldings - were driven past here. I will show you their trail.' He made Temüyin leave the short-haired chestnut horse there, set him on a white horse with a black back, ${ }^{4}$ and he himself rode a fast dun mare. And without even going to his tent, he put down his leather bucket and pail, concealing them in the grass.

'Friend', he said, 'you came to me being in great trouble, but men's troubles are the same for all. I will be

\footnotetext{
1 I.e., 'Blue Lake.'

2 I.e., 'Black Heart.'

3 Lit., 'riding.'

4 Lit., 'with a black stripe along the backbone.'
} 
your companion. My father is called Naqu Bayan. ${ }^{1}$ I am his only son and my name is Bo'orču.'

They spent three days and nights following the trail of the light-bay geldings. Then, in the evening of the fourth day, just as the sun was setting on the hills, ${ }^{2}$ they came upon people in a circular camp. They saw the eight horses, the light-bay geldings, standing at the edge of that large camp, grazing.

Temüjin said, 'Friend, you stay here. As for me - the light-bay geldings are those there - I will go and drive them off!' Bo'orču said, 'I came with you as your companion. How can I stay here?' They raced in together and drove the light-bay geldings off.

91 The men came after them in separate groups and began to pursue them. Away from the rest, one man on a white horse and holding a pole-lasso drew closer and caught up with them. Bo'orču said, 'Friend, give me the bow and arrows. I'll trade shots with him!' Temüjin said, 'I am afraid you'll come to harm because of me. I'll trade shots with him!' He swung around and they began to shoot arrows at each other. The man on the white horse stood up, aiming at him with his pole-lasso. His companions, who had fallen behind, caught up with him, but the sun sank, dusk came down and those men behind, overtaken by darkness, halted and were left behind altogether.

92 They rode all that night and then rode for three more days and nights before they reached their destination. Temüjin said, 'Friend, would I ever have got these horses of mine back without you? Let's share them. How many do you say you'll take?' Bo'orču said, 'I became your companion because you, a good friend, were in trouble and approached me, and I wished to be of help to a good friend. Am I now to take the horses as booty? My father is called Naqu Bayan. I am the only son of Naqu Bayan. The property of my father is ample for me. I won't take

1 I.e., 'Naqu the Rich.'

2 Lit., 'was touching the hilltops.' Cf. below, $§ 171$. 
the horses. What sort of help would my help be? I won't take them.'

93 They arrived at the tent of Naqu Bayan. Naqu Bayan was all in tears for the loss of his son Bo'orču. When they suddenly arrived and he saw his son, he began both to wail and to scold. His son Bo'orču said, 'What is the matter? A good friend came to me in trouble, I became his companion and went with him. Now I have come back.' With this he rode off to fetch his leather bucket and pail which he had concealed in the grass. They killed a lamb fattened on the milk of two ewes and gave it to Temüjin as provision for the road; they also prepared a leather bucket containing mare's milk which they loaded on the horse. In this way, they provided for his journey. Then Naqu Bayan said, 'You two young men keep seeing each other, never abandon each other!'

Temǚ̆in left, and after travelling three days and three nights arrived at his tent on the Senggür Stream. Mother Hö'elün, Qasar and his younger brothers were worrying about him, but when they saw him they rejoiced.

94 Thereupon, Temüjin left with Belgütei downstream along the Kelüren River to look for Lady Börte, the daughter of Dei Sečen, from whom he had been separated since he had visited her at the age of nine.

Dei Sečen, the Onggirat, lived between Mount Čekčer and Mount Čiqurqu. When Dei Sečen saw Temüjun he was very glad. He said, 'I knew that your Tayiči'ut kinsmen were jealous of you, and I worried and despaired; and now at last I see you!' So saying he had him and Lady Börte united as man and wife, and then accompanied her to her new home.

Dei Sečen accompanied her and, as they approached their destination and were still on the way, he turned back at the Uraq Č̈ol Bend ${ }^{1}$ of the Kelüren. His wife, the mother of Lady Börte, was called Čotan. Čotan escorted her daughter and took her to Temüjÿin's home, which at

${ }^{1}$ Lit., 'Corner', i.e. the dry ground or plain in the winding of a river. See RSH 1.391. 
that time was on the Senggür Stream in the Gürelgü Mountains.

After Temü̈y̆in had sent Čotan home, he sent Belgütei to invite Bo'orču to join him as his companion. Bo'orču after receiving Belgütei did not say a word to his father, but

He jumped on his chestnut horse with the arched back,

He tucked his grey woollen cloak behind him and came with Belguitei. This is how they became firm companions after first having joined in friendship.

96 From the Senggür Stream they moved on and set up camp on the Bürgi Escarpment at the source of the Kelüren River.

Čotan had brought a black sable coat as a wedding present for Temü̈̌n's mother. Temüjuin, Qasar and Belgütei took away that coat. In earlier days, Ong Qan of the Kereyit tribe and their father Yisügei Qan had declared themselves sworn friends. ${ }^{1}$ Temü̈̌in said, 'As he and my father have declared themselves sworn friends, Ong Qan is indeed like a father to me.'

Knowing that Ong Qan was staying in the Black Forest by the Tu'ula River, he went there. When he came to Ong Qan, Temuijin said, 'Since in earlier days you and my father declared yourselves sworn friends you are, indeed, like a father to me. ${ }^{2}$ I took a wife, and I have brought the wedding gift to you.' Thereupon, he gave him the black sable coat. Ong Qan was very pleased. He said,

'In return for the black sable coat,

I shall bring together for you

Your divided people;

In return for the sable coat,

I shall unite for you

Your scattered people. Just as

The place of the kidneys must be in the back,

That of good faith must be in the breast!'

\footnotetext{
${ }^{1}$ Anda. See RSH 1.395-96 for discussion of this important term.

${ }^{2}$ See below, $§ 150$.
} 
97 From there they returned home. While they were living on the Bürgi Escarpment, from Burqan Qaldun came Old Jarči'udai, a man of the Uriangqai tribe, carrying his smith's bellows on his back and leading his son called J̌elme. Jarči'udai said, 'When you people were at Deli'ün Boldaq on the Onan River and you Temüjin were born, I gave you sable swaddling-clothes as a gift. I also gave you this son of mine Jelme, but since he was still small I took him back. Now let J̌elme

Put on your saddle,

Open your door.'

So he spoke and handed him over to Temüjin.

98 They had set up camp on the Bürgi Escarpment at the source of the Kelüren River, when early one morning the light was yellowish as day began to dawn - Old Qo'aqčin, who was serving in the tent of Mother Hö'elün, got up and said, 'Mother, mother, rise up quickly! The earth is shaking and one can hear the sound of trampling hoofs: will they be the dreadful Tayiči'ut approaching? Mother, rise up quickly!'

99 Mother Hö'elün said, 'Quickly wake the sons!' Mother Hö'elün also rose in haste. Temüjin and the other sons rose in haste too. They grabbed their horses. Temüjin rode one horse, Mother Hö'elün rode one horse, Qasar rode one horse, Qači'un rode one horse, Temüge Otčigin rode one horse, Belgütei rode one horse, Bo'orču rode one horse, J̌elme rode one horse. Mother Hö'elün put Temülün in front of her on the horse. One horse was harnessed as a spare horse. There was no horse left for Lady Börte.

100 While it was still early Temüjin and his brothers set out in the direction of Mount Burqan. Old Qo'aqčin, in order to hide Lady Börte,

Put her into a sturdy (?) black covered cart,

Harnessed to it an ox with dappled loins,

and moved upstream along the Tenggelik ${ }^{1}$ Stream. As she was proceeding in the dim light - the day was breaking - some soldiers came riding at a trot towards

1 = Tünggelik. 
her. They surrounded her and went up to her, and asked her who she was. Old Qo'aqčin said, 'I belong to Temüjin. I came to shear sheep at the big tent and now I am returning to my tent.' On this, they said, 'Is Temüjin at home? How far is his tent from here?' Old Qo'aqčin said, 'The tent - it is nearby; but whether Temüjuin is there or not I did not notice. I arose and left from the back.'

101 The soldiers then trotted off. Old Qo'aqčin struck the ox with the speckled loins so that they would move along faster, but the axletree of the cart broke in two. As the axletree was broken, they ${ }^{1}$ decided to flee into the forest on foot, but at that very moment the same soldiers came trotting up. Forced to sit on one of the horses behind the rider was the mother of Belgütei, both feet dangling in the air. 'What are you carrying in this cart?', they said. Old Qo'aqčin said, 'I am carrying wool.' The elders of the soldiers said to their younger brothers and sons, 'Dismount and have a look!' The younger brothers and sons dismounted and, having taken off the door of the closed cart, sure enough they found a lady sitting inside. They dragged her out of the cart and made her come down; then, making both her and Qo'aqčin ride behind, they took them away. Following the tracks left in the grass they went after Temüjin in the direction of Mount Burqan.

102 In pursuit of Temüjin they circled Burqan Qaldun three times ${ }^{2}$ but could not catch him. They made detours this way and that - the swallowing quagmires and the tangled woods made so impenetrable a forest that a glutted snake could not creep in - and although they were on his heels they were unable to catch him.

The Three Merkit were Toqto'a of the Uduyit Merkit, Dayir Usun of the U'as Merkit and Qa'atai Darmala of the Qa'at Merkit. Now these Three Merkit had come to take their revenge because Mother Hö'elün had formerly been abducted from Čiledü. ${ }^{3}$ The Merkit said to each

${ }^{1}$ I.e., Old Qo'aqčin and Lady Börte.

2 The expression 'three times' here (and in $\S \S 111,145$ ) must be taken as a hyperbole in view of the size of the mountain and the symbolic value attached to the number three.

${ }^{3}$ See above, $\S \S 54-56$. 
other, 'We have now seized their women to take our revenge for Hö'elün! We have had our revenge!' So saying they descended from Burqan Qaldun and returned to their homes.

103 Temüjin said to himself, 'Have these Three Merkit really returned home, or are they lying in ambush?' He sent Belgütei, Bo'orču and J̌elme after the Three Merkit to spy on them for three days and nights, and having thus made sure that the Merkit had gone a long way off, Temüjin came down from Mount Burqan and, beating his breast, said, 'Because Mother Qo'aqčin's

Hearing is as keen as a weasel's,

Her sight as sharp as an ermine's,

I escaped with my own body whole.

I climbed the Burqan

On a horse hobbled with the halter strap,

Following deer tracks;

A shelter of elm twigs

I made my home.

Thanks to Burqan Qaldun

I escaped with my life, a louse's life.

Fearing for my life, my only life,

I climbed the Qaldun

On one horse, following elk tracks;

A shelter of broken willow twigs

I made my home.

Thanks to Qaldun Burqan ${ }^{1}$

My life, a grasshopper's life,

Was indeed shielded!

But I was greatly frightened. Every morning I will sacrifice to Burqan Qaldun, every day I will pray to it: the offspring of my offspring shall be mindful of this and do likewise!' He spoke and facing the sun, hung his belt around his neck, put his hat over his hand, beat his breast with his fist, and nine times kneeling down towards the sun, he offered a libation and a prayer.

1 = Burqan Qaldun. 


\section{THE SECRET HISTORY OF THE MONGOLS}

\section{CHAPTER THREE}

104 Having thus spoken, Temüjin, with Qasar and Belgütei, went to To'oril Ong Qan of the Kereyit who was then staying in the Black Forest by the Tu'ula River. Temüjin said to him, 'The Three Merkit came, taking us by surprise; they seized my wife and carried her off. We have come now to ask you, O Qan my father, to rescue my wife and return her to me.'

To these words To'oril Ong Qan replied, 'Did I not speak with you last year? When you brought me the sable coat, you said, "Since in my father's time you two declared yourselves sworn friends, you are, indeed, like a father to me." When you put the coat on me, there and then I said,

"In return for the sable coat,

I shall unite for you

Your scattered people;

In return for the black sable coat,

I shall bring together for you

Your divided people. Let

The place of good faith be in the heart, just as

That of the kidneys must be in the back!"1

Did I not say this? I shall now fulfil that promise and

In return for the sable coat,

Even to the complete destruction of the Merkit,

I shall rescue for you your Lady Börte.

In return for the black sable coat,

We shall crush all the Merkit,

We shall cause your wife Börte to return,

Bringing her back to you!

Send a message to younger brother Jamuqa who must now be in the Qorqonaq Valley. I shall set forth from

\footnotetext{
1 See above, $\$ 96$.
} 
here with two units of ten thousand ${ }^{1}$ and form the right wing of the army. Younger brother Jamuqa should set forth with two units of ten thousand to form the left wing. Let Jamuqa decide on the time and place of our meeting!'

105 When Temüǰin, Qasar and Belgütei came back from To'oril Qan's camp and arrived at their tent, Temüjin sent both Qasar and Belgütei to Jamuqa saying, 'Give my sworn friend J̌amuqa this message: "When the Three Merkit came,

My bed was made empty.

You and I,

Are we not from one family?

How shall we take our revenge?

My breast is torn apart.

You and I,

Are we not of kindred blood? ${ }^{2}$

How shall we avenge this injury?",

He sent this message and these were the words he had them convey to his sworn friend Jamuqa. He also told them to report to Jamuqa the words spoken by To'oril Qan of the Kereyit: 'Remembering the help and good things done to me in former days by his father Yisügei Qan, I shall stand by Temüyin. I shall set forth with two units of ten thousand and I shall form the right wing. Send a message to younger brother Jamuqa that he should set forth with two units of ten thousand. As to the time and place of our meeting and joining forces, let younger brother Jamuqa decide!' After they had finished delivering this message, Jamuqa said, 'To know that my sworn friend Temüjuin's

Bed has become empty,

Brought pain to my heart.

To know that his

Breast was torn apart,

Brought pain to my liver.

${ }^{1}$ Tümet: the largest army unit in the decimal system of military organization of the Inner Asian tribes $(10,100,1000,10,000)$, theoretically comprising ten thousand men, but in practice often less (RSH 1.409). We here have the plural (of tümen), a literary exaggeration.

${ }^{2}$ Lit., 'liver', i.e. close relatives. 
Taking our revenge,

Wiping out the Uduyit and U'as Merkit,

We shall rescue our Lady Börte!

Taking our vengeance,

Crushing all the Qa'at Merkit,

We shall rescue your ${ }^{1}$ wife Börte,

Causing her to return!

Now,

That Toqto'a, who takes fright

When one strikes the saddle-flaps, for

He takes it for the sound of the drum,

He must be in the Bu'ura Steppe. ${ }^{2}$

Dayir Usun, who on hearing

The rattle of a loose quiver

Deserts his own companions,

He must now be at Talqun $\mathrm{Aral}^{3}{ }^{3}$

Between the Orqon and the Selengge.

Qa'atai Darmala, who when the saltwort

Is carried by the wind,

Quickly flees into a dark forest,

He must now be in the Qaraji Steppe.

Now, by the shortest way

We shall cross the river Kilqo -

May the sedge be in good growth!

We shall bind our rafts with it,

We shall enter their land.

Descending on the smoke-hole

Of that coward Toqto'a's tent,

Its proud frame ${ }^{4}$ we shall smite,

So it collapses;

We shall kill his wives and children

To the last one.

Of his door the sacred frame,

We shall smite so it shatters;

We shall utterly destroy his people

1 Lit., 'our.'

2 I.e., 'He-Camel Steppe (or Plain).'

3 Lit., 'Talqun Island' - but here a peninsula. Cf. above, $\$ 24$, n. 3.

4 Images of the household gods were placed on both sides of the frame of a yurt's entry door (RSH 1.415). 
Till nothing will be left.'

106 Further, J̌amuqa said, 'Speak to my sworn friend Temüjin and elder brother To'oril Qan, and say to them on my behalf, "As for me,

I have consecrated ${ }^{1}$ my standard

Which is visible from afar;

I have beaten my bellowing drum

Covered with the hide of a black bull;

I have mounted my swift black horse;

I have put on my armour ${ }^{2}$

And grasped my steel spear;

I have placed on the bowstring my arrow with its nock

Of wild peach bark.

I am ready, let us start

And give battle to the Qa'at Merkit!"

Then say to them,

"My long ${ }^{3}$ standard, visible from afar,

I have consecrated; ${ }^{4}$

I have beaten my deep-sounding drum

Covered with ox-hide;

I have mounted my swift horse,

The one with a black stripe along the backbone $;^{5}$

I have put on my leather-strapped breastplate,

And grasped my hilted sword;

I have placed on the bowstring my nocked arrow.

I am ready, let us fight to the death

Against the Uduyit Merkit!"

Then say to them, "After elder brother To'oril Qan has set out and, passing by my sworn friend Temüjin on the southern side of Burqan Qaldun, comes jointly with him, we shall meet at Botoqan Bo'orji at the source of the Onan River. When I set out from here, upstream along

Lit., 'sprinkled.'

2 Lit., 'my steel-hard dress.'

3 Because of the long streamers made of yak tails.

Lit., 'sprinkled.'

5 Cf. above, $\S \S 24,25$ and 90. 
the Onan River where ${ }^{1}$ my sworn friend's people are with one unit of ten thousand taken from his people ${ }^{2}$ and I with one ${ }^{3}$ from here making two units of ten thousand going up along the Onan River we shall join forces at the appointed meeting place in Botoqan Bo'orji."' And he sent them off with this message.

107 Qasar and Belgütei came and reported these words of Jamuqa to Temüjin, who had them conveyed to To'oril Qan.

Upon receiving J̌amuqa's message, To'oril Qan took the field, two units of ten thousand altogether. When To'oril Qan set out, as he was approaching in the direction of the Bürgi Escarpment of the Kelüren on the southern side of Burqan Qaldun, Temüjin, who was then on the Bürgi Escarpment and therefore on To'oril's path, made way for him and, moving upstream along the Tünggelik, set up camp on the Tana Stream ${ }^{4}$ on the southern side of Burqan Qaldun. Temüjin then advanced from there with his troops. When To'oril Qan with one unit of ten thousand and To'oril Qan's younger brother Jaqa Gambu with one unit of ten thousand - two units of ten thousand in all - halted at Ayil Qaraqana on the Kimurqa Stream, Temüjin joined them and set up camp there.

108 Temüjin, To'oril Qan and Jaqa Gambu came together and started off from there. When they arrived at Botoqan Bo'orji at the source of the Onan River, Jamuqa had already reached the meeting place three days before.

Jamuqa, seeing the troops of Temüjin, To'oril and Jaqa Gambu, took up position, ranging his two units of ten thousand troops in battle order. They - Temüjin, To'oril Qan and Jaqa Gambu - likewise ranged their troops in battle order. As soon as they came face to face and recognized each other, Jamuqa said, 'Did we not agree that we won't be late

At the appointed meeting,

${ }^{1}$ Lit., 'here.'

${ }^{2}$ Lit., 'from the sworn friend's people.'

${ }^{3}$ Lit., 'one unit of ten thousand.'

4 I.e., 'Big Pearl Stream.' 
Even if there be a blizzard;

At the gathering,

Even if there be rain?

Are we not Mongols, for whom a "yes" is the same as being bound by an oath? We did agree that

We shall reject from our ranks

Whoever is remiss in his "yes."

To the words of Jamuqa, To'oril Qan said, 'As we are three days late at the meeting place, it is up to younger brother Jamuqa to punish and lay blame!' In this way they exchanged words of reproach about the meeting.

109 Starting from Botoqan Bo'orjin they arrived at the river Kilqo. They made rafts and crossed it. In the Bu'ura Steppe,

Descending on the smoke-hole

Of Toqto'a Beki's tent,

Of his tent the proud frame

They did smite so it collapsed;

They plundered his wives and children

To the last one.

Of his door the sacred frame

They did smite so it shattered;

They utterly plundered his people

Till nothing more was left. ${ }^{1}$

While Toqto'a Beki was asleep, ${ }^{2}$ some fishermen, sable catchers and wild animal hunters who happened to be by the river Kilqo, left it and, travelling all through the night, brought the news of the allies' approach saying, 'The enemies are coming, pushing forward at full speed.' When they received this news, Toqto'a and Dayir Usun of the U'as Merkit joined together, went downstream along the Selengge and entered the Barqujin territory. Few in number and dispossessed of all but their bodies, they escaped by taking flight. ${ }^{3}$

110 At night the Merkit people fled in disarray down the Selengge River, but even in the night our troops were

1 See above, $\S 105$.

2 Lit., 'lying down.'

3 I.e., they barely escaped with their lives. 
pressing hard after the hastily fleeing Merkit. As the pillaging and plundering went on, Temüjin moved among the people that were hurriedly escaping, calling, 'Börte, Börte!' And so he came upon her, for Lady Börte was among those fleeing people. She heard the voice of Temüjin and, recognizing it, she got off the cart and came running towards him. Although it was still night, Lady Börte and Qo'aqčin both recognized Temüjuin's reins and tether and grabbed them. It was moonlight; he looked at them, recognized Lady Börte, and they fell into each other's arms. After this, that very night Temüjin sent a message to To'oril Qan and to sworn friend Jamuqa saying, 'I have found what I was looking for. Let us not travel all night; let us camp here!' He had this message delivered to them. As for the Merkit people who had been fleeing in disarray at night, while still scattering and on the run, they too stopped and spent the night right there. ${ }^{1}$

This is how Lady Börte was rescued from the Merkit tribe, and how she was reunited with Temüÿin.

111 At the very beginning, Toqto'a Beki of the Uduyit Merkit, Dayir Usun of the U'as Merkit and Qa'atai Darmala of the Qa'at Merkit, those three Merkit with three hundred men, said, 'In former days Mother Hö'elün was abducted by Yisügei Ba'atur from Yeke Čiledü, the younger brother of Toqto'a Beki', and they set out to take revenge for that. It was at the time when Temüjin circled Burqan Qaldun three times that they captured Lady Börte. ${ }^{2}$ They entrusted her to Čilger Bökö, the younger brother of Čiledü. As Čilger Bökö had been looking after her ever since, when he fled, deserting his own companions, he said,

'To feed on scraps of skin

Is the black crow's lot - yet

It was goose and crane

It aspired to eat.

I, brutal and base Čilger, who laid my hand

1 I.e., where they happened to be.

2 See above, $\S \S 54-56$ and 100-102. 
On the noble lady,

I have brought disaster

On all the Merkit.

Lowly, base Čilger,

I have come to the point

That I shall lose my black head.

To save my one and only life,

I wish to creep into dark gorges.

Who will act as a shield for me?

To feed on rats and mice

Is the buzzard's, that vile bird's lot - yet

It was swan and crane

It aspired to eat.

I, thieving and base Čilger, who took away

The favoured and fortunate lady,

I have brought disaster upon

The whole of the Merkit.

Boastful, base Čilger,

I have come to the point

That I shall lose my shrivelled head.

To save my life, worth but a sheep's dropping,

I wish to creep into dreadful, dark gorges.

Who will be a shelter for my life

Which is worth but a sheep's dropping?'

Thus he spoke, and escaped, deserting his own companions.

112 They seized Qa'atai Darmala and brought him back,

They forced him to wear a cangue made of a wooden board,

They took him straight to Qaldun Burqan. ${ }^{1}$

Someone informed them that Belgütei's mother was 'in that ayil ${ }^{2}$ over there.' Belgütei went there to fetch his mother, but when he entered her tent by the right-hand door, his mother, in a ragged sheepskin coat, went out by the left-hand door. Outside she said to someone else, 'I am told that my sons have become qans, but here I have been joined with a base man. How can I now look my

1 = Burqan Qaldun. Cf. above, $\$ 103$.

${ }^{2}$ See above, $\S 81$, n. 1. 
sons in the face?' So she spoke and ran off, slipping away into a dense wood. Belgütei Noyan immediately searched for her, but could not find her. He then shot knob-headed arrows ${ }^{1}$ at any man of Merkit stock, saying, 'Bring me my mother!' The three hundred Merkit who had once circled Mount Burqan

Were exterminated, down to

The offspring of their offspring:

They were blown to the winds like hearth-ashes. ${ }^{2}$

Their remaining wives,

Those suitable to be embraced, ${ }^{3}$

Were embraced;

Those suitable to be let into the tent

Through the door and serve as slaves

Were let in through the door.

113 Temüjin, speaking gratefully to To'oril Qan and Jamuqa, said 'Being taken as a companion by my father the Qan and sworn friend Jamuqa, and with my strength increased by Heaven and Earth,

Called by Mighty Heaven,

Carried through by Mother Earth,

We emptied the breasts of the Merkit people

Who take their revenge as a man does,

And we tore their livers to pieces.

We emptied their beds ${ }^{4}$

And we exterminated their relatives;

The women of theirs who remained

We surely took captive!

Thus we destroyed the Merkit people: let us now withdraw!'

114 At the time when the Uduyit Merkit were fleeing in haste, our soldiers found a little boy of five with fire in his eyes who had been left behind in the camp and whose name was Küči. He had a sable cap, boots made from the skin of a doe's forelegs, and a dress of otter skins cleared of hair and sewn together. They took him and

See above, $\$ 77$.

2 Cf. above, $\S 87$.

3 I.e., to be taken as concubines.

${ }^{4}$ I.e., of their wives. 
brought him to Mother Hö'elün, and gave him to her as a present.

115 When Temüj̆in, To'oril Qan and J̌amuqa, after joining their forces

Had smashed the lock-carts,

Had captured the splendid women

of the Merkit, they withdrew from Talqun Aral, between the Orqan ${ }^{1}$ and Selengge rivers. Temüjin with J̌amuqa, withdrawing jointly, went in the direction of the Qorqonaq Valley. On his way back, To'oril Qan passed by the Hökörtü Valley on the northern side of Burqan Qaldun; then passing by Qača'uratu Subčit and Huliyatu Subčit, ${ }^{2}$ where he hunted wild game, he withdrew in the direction of the Black Forest by the Tu'ula River.

116 Temüjin and Jamuqa got together and set up camp in the Qorqonaq Valley. Remembering how earlier on they became sworn friends, they said, 'Let us renew our mutual pledge of friendship, let us now love each other again!'

Earlier, when they had first become sworn friends, Temüjun was eleven years old. J̌amuqa had given Temüjin a roebuck knucklebone, Temüjin in return had given him a copper knucklebone, and so they had become sworn friends. Having declared themselves sworn friends, they had played knucklebones together on the ice of the Onan River. There they had declared each other friends by oath for the first time. ${ }^{3}$

After that, in the spring, as they practised shooting with their firwood bows, Jamuqa split and stuck together the two horns of a two-year-old calf, bored holes in them, and gave this whistling arrowhead of his to Temüjin. In exchange Temüjin gave him a knob-headed arrow with a tip of juniper wood, and they became sworn friends once more.

This is how they declared themselves friends by oath for the second time.

$1=$ Orqon ( Orqan).

2 I.e., 'The Pass with Spruces' and 'The Pass with Aspens.'

3 This is the first mention of their former oath of friendship. 
117 They said to each other, 'Listening to the pronouncement of the old men of former ages which says:

"Sworn friends - the two of them

Share but a single life;

They do not abandon one another:

They are each a life's safeguard for the other."

We learn that such is the rule by which sworn friends love each other. Now, renewing once more our oath of friendship, we shall love each other.'

Temüjin girdled his sworn friend Jamuqa with the golden belt taken as loot from Toqto'a of the Merkit. He also gave sworn friend Jamuqa for a mount Toqto'a's yellowish white mare with a black tail and mane, a mare that had not foaled for several years. Jamuqa girdled his sworn friend Temüjin with the golden belt taken as loot from Dayir Usun of the U'as Merkit, and he gave Temüjin for a mount the kid-white horse with a horn, ${ }^{1}$ also of Dayir Usun. At the Leafy Tree on the southern side of the Quldaqar Cliff in the Qorqonaq Valley they declared themselves sworn friends and loved each other; they enjoyed themselves revelling and feasting, and at night they slept together, the two of them alone under their blanket.

118 Temüjin and Jamuqa loved each other one year and half of the second year. Then one day they decided to move on from their present encampment. They broke camp and set out on the sixteenth of the first month of summer, the day of the Red Circle. ${ }^{2}$

Temüjin and Jamuqa went together in front of the carts, and as they proceeded J̌amuqa said, 'Sworn friend, sworn friend Temüjin,

Let us camp near the mountain:

There will be enough shelter

For our horse-herders!

Let us camp near the river:

There will be enough food ${ }^{3}$ horn.

1 I.e., an excrescence or callosity on its forehead in the shape of a

${ }^{2}$ I.e., 'of the full moon.' Cf. above, $\$ 81$.

${ }^{3}$ Lit., 'food for the gullet.' 
For our shepherds and lamb-herds!'

Temüjin could not understand these words of Jamuqa and remained silent. Falling behind, he waited for the carts in the middle of the moving camp - for it was a moving camp - then Temüǰin said to Mother Hö'elün, 'Sworn friend J̌amuqa said,

"Let us camp near the mountain:

There will be enough shelter

For our horse-herders!

Let us camp near the river:

There will be enough food

For our shepherds and lamb-herds!"

I couldn't understand these words of his, so I did not give him any answer and decided to come and ask you, mother.'

Before Mother Hö'elün could utter a sound, Lady Börte said, 'Sworn friend J̌amuqa, so they say, grows easily tired of his friends. Now the time has come when he has grown tired of us. The words which sworn friend Jamuqa has spoken just now are, therefore, words alluding to us. ${ }^{1}$ Let us not pitch camp, but while we are on the move, let us separate completely from him and move further on, travelling at night!' This, then, is what she said.

119 They all approved of the words of Lady Börte and without pitching camp they set off, travelling at night. As they proceeded, they passed the Tayiči'ut's encampment along the way. The Tayiči'ut, for their part, became frightened and that same night in great confusion actually moved to Jamuqa's side. In the camp of the Besüt in the midst of the Tayiči'ut, our people took a little boy by name of Kököčü who had been left behind in the camp. When they came back they gave him to Mother Hö'elün. Mother Hö'elün took him under her care.

120 They travelled all that night. At daybreak they saw Qači'un Toqura'un, Qaraqai Toqura'un and Qaraldai Toqura'un, the three Toqura'un brothers of the Jalayir tribe, drawing near to join them after having travelled

\footnotetext{
1 I.e., 'words that conceal a scheme against us.'
} 
throughout the night together. Then Qada'an Daldurqan of the Tarqut and his brothers - five Tarqut in all - also drew near. Then the son of Mönggetü Kiyan, Önggür and the others, with their Čangši'ut and Baya'ut followers drew near too. From the Barulas came the brothers Qubilai and Qudus. From the Mangqut came the two brothers Jetei and Doqolqu Čerbi. The younger brother ${ }^{1}$ of Bo'orču, Ögölen Čerbi, ${ }^{2}$ left the Arulat and also came to join his elder brother ${ }^{3}$ Bo'orču. The younger brothers ${ }^{4}$ of J̌elme, Ča'urqan and Sübe'etei Ba'atur, left the Uriangqan and came to join Jelme. From the Besüt also came the two brothers Degei and Küčügür. From the Suldus also came the brothers Čilgütei, Taki and Tayiči'udai. Seče Domoq of the Jalayir also came with his two sons Arqai Qasar and Bala. From the Qongqotan also came Söyiketü Čerbi. Sükegei J̌e'ün, the son of J̌egei Qongdaqor of the Sükeken, also came. Čaqa'an U'a of the Ne'üs came too. There also came Kinggiyadai of the Olqunu'ut, Seči'ür from the Qorolas, and Moči Bedü'ün from the Dörben. Since Butu of the Ikires had made his way here as son-inlaw, ${ }^{5}$ he also came. From the Noyakin came also Jungso, and from the Oronar also came Jirqo'an. From the Barulas came also Suqu Sečen with his son Qaračar. Then Qorči, Old Üsün and Kökö Čos of the Ba'arin together with their Menen Ba'arin followers also came as one camp.

121 When Qorči came he said, 'As we were born from the same woman captured and taken as wife by the august Bodončar,

1 Here $=$ 'cousin.' Some have misunderstood the relationship here; see RSH 1.445.

${ }^{2}$ Also written Ögölei, Ögöle and Ögele. The ancient title čerbi may be translated as 'chamberlain', but the full functions of such an official, apart from supervision of the Qan's domestic staff, are still imperfectly understood (RSH 1.445, 2.690).

3 Here = 'cousin.'

4 Here $=$ 'cousins.'

5 Meaning Temüjin's brother-in-law. Butu was engaged to Temüjin's sister Temülün (then in her lower teens) and married her later (RSH 1.447). 
We are from the same womb,

We are from the one womb water

as Jamuqa. We would not have parted from him, but a heavenly sign appeared before my very eyes, revealing the future to me. There came a fallow cow. She circled Jamuqa and struck his tent-cart with her horns; then she butted him too, breaking one of her two horns. Being thus left with uneven horns, "Bring me my horn!" she kept saying, bellowing repeatedly at Jamuqa as she stood there, hoofing up the ground and raising more and more dust. Then a hornless and fallow ox lifted up the great shaft under the tent, harnessed it on to himself and pulled it after him. As he proceeded following Temuijin on the wide road, he kept bellowing, "Together Heaven and Earth have agreed: Temüjin shall be lord of the people!" and "I am drawing near carrying the people and bringing it to him." These heavenly signs appeared before my eyes; they revealed the future to me. Temijyin, if you become lord of the people, how will you please me for this augury?'

Temüjin said, 'If it is indeed given to me to rule over the people as you say, I will make you a leader of ten thousand.'

Qorči said, 'What kind of happiness is it for me, the man who foretold so many great affairs, merely to become the leader of ten thousand? Make me a leader of ten thousand, but in addition allow me to take freely beautiful and fine girls from among the people, and let me have thirty as wives. And again, whatever I say, heed me closely!'

122 The Geniges, with Qunan at their head, also came as one camp. Then came Dāritai Otčigin - also one camp. From the J̌adaran came also Mulqalqu. And the Ünjin and the Saqayit came - also one camp. When Temüjin had parted company in this way from J̌amuqa and had moved further on, setting up camp at Ayil Qaraqana by the Kimurqa Stream, ${ }^{1}$ there came, also separating from J̆amuqa, the sons of Sorqatu Jürki of the Jürkin, Sača Beki

1 See above, $\$ 107$. 
and Taiču - one camp; then the son of Nekün Taiši, Qučar Beki - one camp; and the son of Qutula Qan, Altan Otčigin - one camp. These, then, left Jamuqa and moved on, and when Temüjin set up camp at Ayil Qaraqana by the Kimurqa Stream, they joined camp with him. From there they went on, and camped at Kökö Na'ur of Mount Qara J̌irügen by the Senggür Stream in the Gürelgü Mountains. ${ }^{1}$

123 Altan, Qučar and Sača Beki, all of them having agreed among themselves, said to Temüj̆in, 'We shall make you qan. When you, Temüjin, become qan, we

As vanguard shall speed

After many foes: for you

Fine-looking maidens and ladies of rank,

Palatial tents, and from foreign people

Ladies and maidens with beautiful cheeks,

And geldings with fine croups

At the trot we shall bring.

When in a battue ${ }^{2}$ we hunt the cunning

Wild beasts, for you

We shall go ahead and round them up.

For you we shall drive the beasts of the steppe

Until their bellies press together;

For you we shall drive the beasts of the steep banks

Until their thighs press together.

In the days of war,

If we disobey your commands,

Deprive us of all our goods and belongings, and

Our noble wives, and cast

Our black heads on the ground!

In the days of peace,

If we violate your counsel,

Cut us off from our retainers and possessions, and

Our wives, and cast us

Out into the wilderness!'

Thus they pledged their word and in

1 See above, $\$ 89$.

$2=$ a circular battue, i.e. a hunt in which the game is driven towards a central point. 
This way they swore the oath of loyalty, and made Temüj̆in qan, naming him Činggis Qa'an.

124 Having become qa'an, Činggis ordered the younger brother ${ }^{1}$ of Bo'orču, Ögölei Čerbi, ${ }^{2}$ to carry a quiver, Qači'un Toqura'un to carry a quiver, and the two brothers Jetei and Doqolqu Čerbi each to carry a quiver.

Önggür, Söyiketü Čerbi and Qada'an Daldurqan then spoke, saying,

'We shall not let you go without

Your morning drinks;

We shall not neglect your drinks

In the evening!'

And so they became stewards. Then Degei spoke:

'In making broth

Of a two-year-old wether,

I shall not fail in the morning,

I shall not be remiss at night.

I shall tend pied sheep,

And shall fill the bottom of the cart with them.

I shall tend brown sheep,

And shall fill the sheep-fold with them.

I was a base and greedy man: now

I shall tend sheep,

And tripe shall I eat!'

So Degei tended the sheep. His younger brother, Güčügür ${ }^{3}$ spoke:

'I shall not let the linchpin slip

Off a lock-cart;

I shall not let an axle-cart collapse

On the road.

I shall manage the tent-carts!', he said. And Dödei Čerbi said, 'I shall be in charge of the domestics and servants in the tent!'

Qubilai, Čilgütei and Qarqai Toqura'un together with Qasar were ordered to carry swords. To them Činggis Qa'an said,

1 Here $=$ 'cousin.' See above, $\$ 120$.

2 The Ögölen Čerbi of $\$ 120$ above.

3 The Küčügür of $\$ 120$ above. 
'Cut the neck of the braggart, ${ }^{1}$

Cleave the breast of the arrogant!'

And he said, 'Let Belgütei and Qaraldai Toqura'un

$\mathrm{Be}$ in charge of the geldings,

Be $m y$ equerries!'

And he said, 'Tayiči'udai, Qutu Moriči ${ }^{2}$ and Mulqalqu

shall tend the herds of horses!'

And he said, 'Let Arqai Qasar, Taqai, Sükegei and

$$
\text { Ča'urqan }
$$

Be my far-flying shafts,

Be my near-flying arrows! ${ }^{3}$

Sübe'etei Ba'adur spoke:

'I shall be a rat,

And with the others

I shall hoard up goods for you;

I shall be a black crow,

And with the others

I shall gather for you

All that is found outside;

I shall be a felt covering,

And with the others

I shall try to make a cover for you; ${ }^{4}$

I shall be a felt windbreak,

And with the others

I shall try to shelter $y o u^{5}$

From the wind on your tent!'

125 Thereupon, when Činggis Qa'an became qan, he said to Bo'orču and J̌elme, 'You two,

When I had no friend but my shadow,

Became my shadows; and truly

Brought peace to my mind.

In my mind you shall dwell!'

And he said,

'When I had no whip

But my horse's tail, you

1 Plural in the text.

2 I.e., 'Qutu the Horse-herder.'

3 A simile for trusted envoys.

4 Or 'I shall cover and protect you.'

5 Or 'I shall shelter and protect you.' 
Became my horse's tail; and truly

Brought peace to my heart.

In my breast you shall dwell!'

So he spoke, saying to them, 'You two, who stood by me from the beginning, will you not be at the head of all these here?'

Further, Činggis Qa'an said, 'When Heaven and Earth increased my strength and took me into their protection, you, the senior ones, who for my sake came over from sworn friend J̌amuqa wishing to become companions, will you not be my lucky companions? I have appointed each of you to your respective office.'

126 He sent Daqai ${ }^{1}$ and Sügegei ${ }^{2}$ as envoys to To'oril Qan of the Kereyit with the message that they had made Činggis Qa'an their qan. To'oril Qan sent them back with the following message: 'To make my son Temüjun qan is indeed right. How can the Mongols be without a qan? In future

Do not break this, your agreement,

Do not dissolve your bond,

Do not tear off your collar! 3

1 The Taki of $\S 120$ and Taqai of $\S 124$ et passim.

2 The Sükegei (J̌e'ün) of $\S \S 120$ and 124 above.

${ }^{3}$ I.e., 'Do not reject your leader.' Cf. above, $\$ 33$. 


\title{
THE SECRET HISTORY OF THE MONGOLS
}

\author{
CHAPTER FOUR
}

127 Činggis Qa'an sent Arqai Qasar and Ča'urqan as envoys to Jamuqa. Jamuqa said, 'Give this message to Altan and Qučar: "Why did you, Altan and Qučar, cause a split between sworn friend Temüj̆in and myself, ${ }^{1}$ by

Poking in the flanks,

Pricking the ribs

of the sworn friend $?^{2}$ Why did you not make sworn friend Temüjin qan when we were still together - without causing the sworn friend and $\mathrm{me}^{1}$ to fall apart? Just what did you have in mind now, when you made him qan? You, Altan and Qučar, keep to the words you have spoken, put the sworn friend's mind at ease, be the good companions of my sworn friend!" He sent them back with this message.

128 After that, when Taičar, a younger kinsman ${ }^{3}$ of Jamuqa, stayed at Ölegei Spring ${ }^{4}$ on the southern side of Mount Jalama, he went to steal the herd of horses of our Joči Darmala, who was staying in the Sa'ari Steppe. ${ }^{5}$

Taičar stole J̌oči Darmala's herd of horses and took them away. The same Joči Darmala, thus robbed of his herd, went alone in pursuit, his companions lacking the courage to go with him.

That night he arrived at the fringe of his herd. He approached crouching over the mane of his horse, shot and killed Taičar with an arrow that split apart his spine, then took his horses and returned.

1 Lit., 'us.'

${ }^{2}$ I.e., with stinging and malicious words. For Altan and Qučar's role, see above, $\S 123$.

3 Lit., 'younger brother.' See $\$ \S 68$ and 74 , and note Jamuqa's explicit statement in $\$ 201$ that he had no younger brothers.

4 Lit., 'Cradle Spring.'

5 I.e., 'Rump(-like) Steppe (or Plain).' 
129 Because his younger kinsman Taičar had been killed, Jamuqa, at the head of the Jadaran, and his allies making thirteen tribes and forming altogether three units of ten thousand, crossed the Ala'ut Turqa'ut ${ }^{1}$ Mountains and moved against Činggis Qa'an. News of their approach was brought to Činggis Qa'an, who was then staying in the Gürelgü Mountains, by Mülke Totaq and Boroldai of the Ikires.

Informed of this, Činggis Qa'an with his thirteen camps formed also three units of ten thousand and set out against J̌amuqa. They fought at Dalan Baljut: ${ }^{2} \check{C}_{\text {inggis }}$ Qa'an was repulsed there by Jamuqa and sought refuge in the J̌erene Gorge by the Onon $^{3}$ River. Jamuqa said, 'We have forced him to take refuge in the Jerene by the Onon', and, as he was about to return home, Јатиqa had the princes of the Činōs boiled alive in seventy cauldrons. Having cut off the head of Čaqa'an U'a of the Ne'üs, he dragged it away bound to the tail of his horse.

130 Then, letting J̌amuqa return home from there, Jürčedei of the Uru'ut at the head of the Uru'ut, and Quyuldar of the Mangqut at the head of the Mangqut deserted Jamuqa and came over to Činggis Qa'an. Father Mönglik of the Qongqotat was then with Jamuqa. Father Mönglik with his seven sons also deserted J̌amuqa and joined Činggis Qa'an.

Because these tribes were coming in from Jamuqa's side, Činggis Qa'an rejoiced, saying to himself that the whole nation was coming over to him. Činggis Qa'an, Lady Hö'elün and Qasar, together with Sača Beki, Taiču and others of the Jürkin, decided to hold a feast in the forest by the Onan.

In the course of feasting, one pitcher of kumis was first poured for Činggis Qa'an, Lady Hö'elün, Qasar, Sača Beki and others. As one pitcher was also poured to the women starting with Ebegei, the secondary wife of

1 I.e., 'Mottled Sentinels.'

2 I.e., 'Seventy Marshes.'

$3=$ Onan ( Onon). 
Sača Beki's father, ${ }^{1}$ both Qoriǰin Qatun and Qu'určin Qatun said, 'Why didn't they pour first for me, but began with Ebegei?', and they thrashed the steward Šiki'ür. As he was being thrashed, the steward Šiki'ür said, 'What sort of thing is it, your thrashing me like this, just because Yisügei Ba'atur and Nekün Taiši are dead?' So he spoke and cried out loudly.

131 That feast had been arranged on our side by Belgütei. He was standing outside the camp keeping Činggis Qa'an's geldings. ${ }^{2}$ From the Jü̈kin's side Büri Bökö had arranged the feast.

A man of the Qadagin tribe stole a tether from our horse station. Belgütei caught the thief, but Büri Bökö took that man under his protection. Now, Belgütei, when wrestling, used to remove his right sleeve and go on fighting bare-armed. On this occasion, Büri Bökö's sword split open his shoulder, which had been left exposed and bare. ${ }^{3}$ Although cut in this way, still Belgütei, thinking nothing of it, did not bother and let the blood flow. But Činggis Qa'an, sitting in the shade, saw what happened from the place of the feast. He stepped out and said, 'How can we be treated like this?' Belgütei said, 'The wound isn't that bad yet! On my account, I fear we may fall out with our kinsmen. There is nothing wrong with me, I am recovering. Elder brother, now that we have just grown friendly with our kinsmen, do not act, wait a little while!'

132 Although warned in this way by Belgütei, Činggis Qa'an did not comply: breaking off tree branches, pulling out the churners of the kumis leather bags and grabbing them, they started to beat each other. Cinggis Qa'an and our men overcame the Jürkin and forcibly seized both Qoriǰin Qatun and Qu'určin Qatun. Later, however, on being told, 'We ${ }^{4}$ want to make peace', they returned both Qoriǰin Qatun and Qu'určin Qatun to the Jürkin.

${ }^{1}$ Lit., 'the little mother of Sača Beki' - 'little mother' being the designation of a secondary wife or concubine.

${ }^{2}$ As Činggis' equerry. See above, $\S 124$.

3 This is the episode referred to in $\$ 50$ above.

${ }^{4}$ I.e., the Jürkin. 
It was when messengers were still being sent from one side to the other to make peace that Činggis Qa'an learned the news that the Altan Qan of the Kitat people, because Megüjin Se'ültü and others of the Tatar would not enter into an agreement with him, had then sent word to Ongging Čingsang that he should array his troops without delay and set out against them. Thereupon, Ongging Čingsang had driven Megüj̆in Se'ültü and the other Tatars, together with their livestock, upstream along the Ulja, and was now approaching.

133 Having learned this news, Činggis Qa'an said, 'From old days, the Tatar people have been our mortal enemies, the people who have destroyed our fathers and forefathers. ${ }^{1}$ Now, taking this opportunity, let us jointly attack them!' And he sent an envoy to deliver this message to To'oril Qan: 'It is reported that the Altan Qan's commander Ongging Čingsang has driven the Tatar Megüjin Se'ültü and other Tatars upstream along the Uly̆a and is now approaching. Let us jointly attack the Tatars who have destroyed our fathers and forefathers. To'oril Qan, my father, should come quickly!'

When this message was delivered, To'oril Qan said, 'The word my son has sent is right. Let us jointly attack!' Thereupon, on the third day, To'oril Qan, having assembled his troops, set out with his army and quickly went to his assistance.

Činggis Qa'an and To'oril Qan sent a message to the Jürkin Sača Beki and Taiču, and to the other Jürkin: 'Now, taking this opportunity, let us jointly attack the Tatars who from of old have destroyed our fathers and forefathers. Together let us set forth against them!'

They sent the message and having waited for six days from the time it should have come to the Jürkin, Činggis Qa'an and To'oril Qan, unable to wait any longer, together set out with their troops. As they approached, moving downstream along the Ulya to launch the attack in conjunction with Ongging Čingsang, the Tatar Megüj̆in and the other Tatars built a stockade there, at Qusutu 
Šitü'en and Naratu Šitü'en ${ }^{1}$ by the Ulja. Činggis Qa'an and To'oril Qan captured those who had barricaded themselves in this way, among them Megüjin Se'ültü from the stockade. They killed Megüjin Se'ültü on the spot; Činggis Qa'an then took as booty his silver cradle and his blanket decorated with big pearls.

134 Činggis Qa'an and To'oril Qan [went to meet Ongging Čingsang and] told him that they had killed Megüjin Se'ültü. Ongging Čingsang was very glad when he learned that Megüj̆in Se'ültü had been killed. He gave Činggis Qa'an the title $\breve{y a}^{\prime}$ ut quri ${ }^{2}$ and, at the same time, he gave the title of ong $^{3}$ to To'oril of the Kereyit. ${ }^{4}$ The name Ong Qan thus originates from the time when it was first given to To'oril as a title by Ongging Čingsang.

Ongging Čingsang said, 'You have done a very great service to the Altan Qan by your joint attack on Megüjin Se'ültü and by killing him. I shall inform the Altan Qan of this service of yours. Let the Altan Qan decide whether a title higher than the present one ${ }^{5}$ should be further conferred on Činggis Qa'an - whether he should be given the title of jautau. ${ }^{6}$ Rejoicing in this way, Ongging Čingsang withdrew from there.

On that occasion, Činggis Qa'an and Ong Qan plundered the Tatars and shared the booty, each taking his part; then they returned to their own encampments. ${ }^{7}$

135 At the time when our troops were plundering the camp at Naratu Šitü'en where the Tatars had halted and barricaded themselves, they happened to find in the camp a little boy who had been abandoned. Taking back the little boy, who had as nose-ring a golden loop and who wore a gold-stitched silken waistcoat lined with sable, Činggis Qa'an gave him as a present to Mother Hö'elün.

1 I.e., 'Birch Rampart' and 'Pine Rampart.'

2 I.e., 'Commander of Hundreds (?).'

3 I.e., 'King' or 'Prince.'

${ }^{4}$ Gereyit in the text.

${ }^{5}$ Lit., 'this.'

${ }^{6}$ I.e., 'Pacification Commissioner.'

${ }^{7}$ Lit., 'they went back and set up camp.' 
Mother Hö'elün said, 'He must be the son of a man of rank; surely he is the offspring of a man of noble origins!' The Mother named him Šikiken Quduqu ${ }^{1}$ and brought him up as the younger brother of her five children and as her sixth child.

136 The base camp of Činggis Qa'an was at Lake Hariltu. From among those who had remained at the base camp, the Jürkin stripped fifty men of their clothing and killed ten men.

When those of us who were left at the base camp told Činggis Qa'an that they had been treated in that way by the Jürkin, Činggis Qa'an on hearing this news became very angry and said, 'How could we be treated in such a manner by the Jürkin? When we held a feast in the forest by the Onan they also thrashed the steward Šiki'ür, and it was they who also cut Belgütei's shoulder. We were told we should make peace, and gave them back both Qorijin Qatun and Qu'určin. After that, we said that we would set out and jointly attack the Tatars who, full of hatred and resentment, had from old destroyed our fathers and forefathers. Although we waited six days for the Jürkin, they failed us by not coming. ${ }^{2}$ And now, by siding in this way with $^{3}$ the enemy, they themselves have also become our enemies!' Having said this, Činggis Qa'an moved against the Jürkin.

When the Jürkin were staying at Dolo'an Bolda'ut ${ }^{4}$ of Ködö'e $\mathrm{Aral}^{5}$ on the Kelüren River, Činggis Qa'an plundered their people. Sača Beki and Taiču, being few in number and dispossessed of all but their bodies, escaped. ${ }^{6}$ He pursued them and, overtaking them at the Telētiu Pass, he caught Sača Beki and Taiču.

$1=$ Šigiken Qutuqu. See below, §138, and RSH xxxvi-xl, 1.498-99.

2 See above, $\$ \S 132$ and 133.

3 Lit., 'leaning on.'

4 I.e., 'Seven Solitary Hills.'

${ }^{5}$ I.e., 'Barren Island', but see RSH 1.501-02 for the name and location of this place (where, according to $\$ 282$, the Secret History was recorded for the first time).

6 Cf. above, $\$ 109$. 
After their capture, Činggis Qa'an said to Sača and Taiču, 'What did we agree upon in the old days?' Being so addressed, Sača and Taiču said, 'We did not keep to the words we spoke. Now make us comply with them!'1 And, admitting their oath, they held out their necks to the sword.

Making them to admit their oath and causing them to comply with their words, he executed them and cast off their bodies there and then.

137 Having disposed of Sača and Taiču he returned to the Jürkin camp. As he was about to move the Jürkin people away, the three sons of Telegetü Bayan of the Jalayir, Gü'ün U'a, Čila'un Qayiči and Jebke, were with these Jürkin at the time. Gü'ün U'a, with his two sons Muqali and Buqa, came to pay homage to Činggis Qa'an and said,

'Let these sons of mine be the slaves

Of your threshold; ${ }^{2}$

If they stray from your threshold,

Cut off their heel tendons!

Let them be the personal slaves

Of your door;

If they abandon your door,

Cut out their livers and

Cast them away!'

So saying he handed them over to him.

Čila'un Qayiči with his two sons Tüngge ${ }^{3}$ and Qaši also came to pay homage to Činggis Qa'an and spoke thus:

" "Let them guard

Your golden threshold", so saying,

I give you these sons of mine;

If they depart from your golden threshold,

Put an end to their lives and

1 Lit., 'with our words.'

2 The slaves referred to here and just below were the Qan's personal slaves (emčü bo'ol), i.e., his personal property. For the literature on bo'ol ('slave' in general) and slavery in early Mongolian society see RSH 1.505-07, 3.88 .

3 Called Tüge in $\S \S 202$ and 225 below. 
Cast them away!

"Let them lift for you

The wide felt door", so saying,

I give them to you;

If they desert your wide door,

Kick them in the pit of the stomach and

Cast them away!'

Thus he spoke. Činggis Qa'an gave Jebke to Qasar. Jebke, bringing with him from the Jürkin camp a little boy called Boro'ul, paid homage to Mother Hö'elün and gave him to her.

138 Mother Hö'elün reared in her tent these four: the boy called Güčü ${ }^{1}$ found in the Merkit camp, the boy called Kököčü found in the Besüt camp among the Tayiči'ut, the boy called Šigiken Qutuqu found in the Tatar camp, and the boy called Boro'ul found in the Jürkin camp. Mother Hö'elün said, 'Whom but these foundlings will I make

Eyes, for my sons to see in the day,

Ears, for my sons to hear at night?' - and reared them in her tent.

139 As for the manner in which those Jürkin people came to be Jürkin, the eldest ${ }^{2}$ among the seven sons of Qabul Qan was Ökin Barqaq, whose son was Sorqatu Jürki. <As they came to be Jürkin> Qabul Qan, saying that Ökin Barqaq was his eldest son, ${ }^{3}$ chose men for him from among his own people and, having chosen them, gave him strong and mighty men who had

Gall in their livers, ${ }^{4}$

Thumbs good at shooting,

Lungs filled with courage,

Mouths full of fury,

And, all, men of skill.

Because they had fury and gall, and were proud and inflexible, that is the reason why they were called Jürkin.

Činggis Qa'an subjugated such a proud people and

1 Written Küčü in $\$ 114$ above.

2 Lit., 'the eldest brother.'

3 Lit., 'saying that he was the eldest brother of Qabul Qan's sons.'

${ }^{4}$ I.e., who were brave and daring. 
destroyed all those who were of the Jürkin clan. $\mathrm{He}^{1}$ made the tribe and its people his personal subjects.

140 One day Činggis Qa'an said, 'Let us make Büri Bökö and Belgütei wrestle with each other!'

Formerly, when Büri Bökö was still with the Jürkin, seizing Belgütei with one hand and tripping him with one foot, Büri Bökö toppled him and held him down so that he could not move. ${ }^{2}$ Büri Bökö was the strongest man among his people.

Činggis Qa'an now made Belgütei and Büri Bökö wrestle. Büri Bökö, the invincible, let himself be toppled. Belguitei, unable to hold him down, grabbed his shoulders and straddled him. Belgütei glanced backwards and, when he caught sight of Čnggis Qa'an's eye, the Qa'an bit his lower lip. Belgütei understood. He sat on top of Büri Bökö and, crossing the two ends of his collar, he pulled them towards himself, tightening his grip. As he did that, he pressed his knee on his spine and broke it.

Büri Bökö, his spine broken, said, 'I would not have been defeated by Belgütei, but fearing the Qa'an, I took a fall on purpose. I hesitated, so I lost my life.' Thus he spoke and died.

After Belgütei had pulled and broken his spine, he dragged Büri Bökö away, cast him off and left.

Of the seven sons of Qabul Qan, Ökin Barqaq was the eldest; the next one was Bartan Ba'atur, whose son was Yisügei Ba'atur. The next one after him ${ }^{3}$ was Qutuqtu Möngler, ${ }^{4}$ whose son was Büri. Overstepping the line of the sons of Bartan Ba'atur which was nearest above him in order of seniority, he became a companion of the proud sons of Barqaq. Because of this, Büri Bökö, the strongest man among his people, perished, his spine broken by Belgütei.

141 After that, in the Year of the Hen (1201), the Qadagin and the Salji'ut united, and the following ${ }^{5}$ tribes gathered

Lit., 'Činggis Qa'an.'

2 There is no previous mention of this episode.

${ }^{3}$ I.e., after Bartan Ba'atur.

4 The Qutuqtu Mönggür of $\S \S 48$ and 50 above.

5 Lit., 'these.' 
at Alqui Spring: ${ }^{1}$ the Qadagin led by Buqu Čorogi of the Qadagin, and the Salji'ut led by Črgidai Ba'atur of the Salji'ut; the Dörben, who had made peace with the Tatar, led by Qaji'un Beki of the Dörben, and the Tatar led by Jalin Buqa of the Alči Tatar; the Ikires led by Tüge Maqa of the Ikires; the Onggirat led by Terge Emel, Alqui and others of the Onggirat; the Qorolas led by Čnaq Čaqa' ${ }^{2}{ }^{2}$ and others of the Qorolas; also Buyiruq Qan of the Güčü'üt Naiman from the Naiman; Qutu, the son of Toqto'a Beki of the Merkit; Quduqa Beki of the Oyirat; and, from the Tayiči'ut, Tarqutai Kiriltuq, Qodun Örčeng, A'uču Ba'atur and other Tayiči'ut. Saying, 'Let us raise Jamuqa the Jajirat as qan', they jointly hacked the backs of a stallion and a mare and together swore an oath of friendship.

From there they moved downstream along the Ergüne River, and on the large promontory of the peninsula where the Kan River flows into the Ergüne, there they raised J̌amuqa as gür qan. ${ }^{3}$ After raising him as gür qan, they decided to set out to attack Činggis Qa'an and Ong Qan.

Word of this - that they had decided to attack - was sent by Qoridai of the Qorolas to Činggis Qa'an, when $\mathrm{he}^{4}$ was staying in the Gürelgü Mountains.

When he received this news, Činggis Qa'an passed it ${ }^{5}$ on to Ong Qan. As soon as Ong Qan received the news, $\mathrm{he}^{6}$ set his army in motion and speedily arrived at Činggis Qa'an's camp.

142 After getting Ong Qan to come, Činggis Qa'an and Ong Qan decided to move jointly against Jamuqa. They set out downstream along the Kelüren River. Činggis Qa'an sent Altan, Qučar and Dāritai as vanguard; Ong

${ }^{1}$ Lit., 'Sarsaparilla Spring.'

2 ? Čo'oq Čaqa'an, ? Čo'os Čaqa'an. For the other names in this section see RSH 1.515-9.

3 I.e., 'Universal Ruler.' 'Kan River' or 'Ken River' (reading doubtful); see also RSH 3.89-90.

${ }^{4}$ I.e., Činggis Qa'an.

${ }^{5}$ Lit., 'this news.'

${ }^{6}$ Lit., 'Ong Qan.' 
Qan for his part sent as vanguards Senggüm, Jaqa Gambu and Bilge Beki. Patrols were also dispatched ahead of these vanguards: at Enegen Güiletiü ${ }^{1}$ they set up an observation post; beyond that, at Mount Čekčer, they set up another observation post; and beyond that, at Mount Čiqurqu, they set up a further observation post.

Altan, Qučar, Senggüm and the others of our vanguard arrived at Utkiya. While they were deciding whether to camp there, a man from the observation post which had been set up at Čiqurqu came riding in haste and brought the news that the enemy was approaching.

When this news came, without setting up camp they went towards the enemy in order to gain information. They met and gained the information: when they asked the enemy patrol who they were, it turned out to be Jamuqa's vanguard consisting of A'uču Ba'atur of the Mongols, Buyiruq Qan of the Naiman, Qutu, the son of Toqto'a Beki of the Merkit, and Quduqa Beki of the Oyirat. These four had been going towards $u s$ as Jamuqa's vanguard.

Our vanguard shouted at them, and they shouted back, but it was already getting late. Saying, 'Tomorrow we'll fight!', our men withdrew and spent the night together with the main body of the army.

143 Next day the troops were sent forward and when they met, at Köyiten, ${ }^{2}$ they battled. As they pressed on each other downhill and uphill, and reformed their ranks, those very same Buyiruq Qan and Quduqa, knowing how to produce a rainstorm by magic, started to conjure $\mathrm{it}^{3}$ up, but the magic storm rolled back and it was right upon themselves that it fell. Unable to proceed, they tumbled into ravines. Saying to each other, 'We are not loved by Heaven!', they scattered.

144 Buyiruq Qan of the Naiman separated from the rest and went towards Uluq $\mathrm{Taq}^{4}$ on the southern side of the

\footnotetext{
1 I.e., 'Having a Single Apricot Tree (?).'

2 I.e., 'Cold.'

3 Lit., 'the magic storm.'

4 I.e., 'Great Mountain' (tu.).
} 
Altai Mountains. Qutu, the son of Toqto'a of the Merkit, went towards the Selengge River. Quduqa Beki of the Oyirat went towards the Šisgis River, making for the forest. A'uču Ba'atur of the Tayiči'ut went towards the Onan River. Jamuqa plundered the very people who had elected him qan; then $\mathrm{h}^{1}$ moved homewards following the course of the Ergüne. As they were dispersing in this way, Ong Qan pursued Jamuqa downstream along the Ergüne while Činggis Qa'an pursued A'uču Ba'atur of the Tayiči'ut in the direction of the Onan.

As soon as A'uču Ba'atur reached his own people, he had them moved along with him in haste. The Tayiči'ut A'uču Ba'atur and Qodun Örčeng arrayed their troops at Ülengüt Turas ${ }^{2}$ on the other side of the Onan, and stood in battle order ready to fight. ${ }^{3}$

Činggis Qa'an came up and fought with the Tayiči'ut. They battled to and fro incessantly until evening came; then, in the same place where they had been fighting, they passed the night right next to each other. When people ${ }^{4}$ arrived, fleeing in disarray, they set up a circular camp and also passed the night in the same spot, alongside their troops.

145 In that battle Činggis Qa'an was wounded in a vein of the neck. He could not stop the bleeding and was in a great plight. He waited till sundown, then he pitched camp just there where the two armies had encamped right next to each other.

Jelme sucked and sucked the blood which clogged Cinggis Qa'an's wound and his mouth was all smeared with blood. Still, Jelme, not trusting other people, stayed there and looked after him. Until the middle of the night he swallowed down or spat out mouthfuls of the clogging blood. ${ }^{5}$

1 Lit., 'J̌amuqa.'

${ }^{2}$ For this reading see RSH 1.527; an error of the Ming editors is continued in some modern editions and translations of the text.

${ }^{3}$ Lit., 'saying, "We shall fight!".'

${ }^{4}$ I.e., the refugees.

${ }^{5}$ If a poisoned arrow had been used, continuous flow of blood from the wound would reduce the danger of dying of poison (see RSH 1.528). 
When midnight had passed Činggis Qa'an revived and said, 'The blood has dried up completely; I am thirsty.' Then Jelme took off his hat, boots and clothes everything - and stark naked but for his pants, he ran into the midst of the enemy who had settled right next to them. He jumped on to a cart of the people who had set up a circular camp over there. He searched for kumis, but was unable to find any because those people had fled in disarray and had turned the mares loose without milking them.

As he could not find kumis, he took from one of their carts a large covered bucket of curds and carried it back. In the time between his going and coming back he was not seen by anyone. Heaven indeed protected him!

Having brought the covered bucket of curds, the same J̌elme, all by himself, searched for water, brought it back, and having mixed it with the curds got the Qa'an to drink it.

Three times, resting in between, the Qa' an drank, then he spoke: 'The eyes within me have cleared up.' He spoke and sat up: it was daybreak and growing light. He looked and saw that, all about the place where he was sitting, the wound-clogging blood that Jelme had kept on sucking and had spat about had formed small puddles. When he saw it, Činggis Qa'an said, 'What is this? Couldn't you have spat the blood farther away?' Jelme then said, 'When you were in a great plight, had I gone farther away I would have feared being separated from you. As I was in haste, I swallowed what I could swallow and spat out what I could spit out; I was in a plight myself and quite a lot went also into my stomach!'

Činggis Qa'an again spoke: 'When I was in this state, lying down, why did you run naked into their camp? Had you been caught, wouldn't you have revealed that I was like this?' Jelme said, 'My thought, as I went naked, was that if somehow I got caught, I would have said, "I wanted to submit to you, but they ${ }^{1}$ found out and, seizing me, decided to kill me. They removed my clothes -

${ }^{1}$ I.e., Činggis Qa'an’s people. 
everything - only my pants had not yet been removed when I suddenly managed to escape and have just come in haste to join you." They would have regarded me as sincere, they would have given me clothes and looked after me. Then, I would have jumped on a horse and while they were astonished watching me flee, in that brief moment I would have surely got back! So thinking, and because I wished to get back in time to satisfy the Qa'an's craving for drink caused by his parching thirst, thinking this and without so much as blinking an eye I went there.'

Činggis Qa'an said, 'What can I say now? In former days, when the Three Merkit came and thrice circled Mount Burqan, you saved my life for the first time. ${ }^{1}$ Now, once more, you restored me to life when, with your mouth, you sucked the clotting blood from my wound. And, yet again, when I was in a great plight with a parching thirst, disregarding your life, you went amidst the enemy without so much as blinking an eye; you quenched my thirst and restored life to me. These three services of yours will stay in my heart!' Thus the Qa'an spoke.

146 When it had grown light, it turned out that the enemy troops who were bivouacking right next to us had dispersed during the night; only the people who had set up the circular camp had not moved from the place where they had encamped because they would not have been able to get away.

Činggis Qa'an moved from the place where he had spent the night in order to bring back ${ }^{2}$ the people who had fled. As he was bringing back the fugitives, Činggis Qa'an himself heard a woman in a red coat who, standing on top of a ridge, was wailing loudly, crying 'Temüj̆in!' He sent a man to enquire whose wife was the woman who was crying like that. The man went and, having asked her, that woman said, 'I am the daughter of Sorqan Šira and my name is Qada'an. ${ }^{3}$ The soldiers here captured my

1 This event is not recorded in $\$ 102$ above.

2 I.e., to recapture.

3 She is mentioned in $\S 85$ above. 
husband and were going to kill him. As my husband was being killed, I cried and wailed and called on Temüjin to save my husband.' So she said, and the man returned and reported these words to Činggis Qa'an.

On hearing these words, Činggis Qa'an rode at a trot and reached her; he ${ }^{1}$ dismounted near Qada'an and they embraced each other, but her husband had already been killed by our soldiers.

After Činggis Qa'an had brought back those people, he camped on the spot for the night with his great army. He invited Qada'an to come to him and had her sit by his side.

The following day, Sorqan Šira and J̌ebe, who had been retainers of Tödöge of the Tayiči'ut, also arrived the two of them. Činggis Qa'an said to Sorqan Šira, 'It was indeed a good service of you, father and sons,

To throw to the ground

The heavy wood on my neck,

To remove the wooden cangue

That was on my collar.

Why, then, did you delay coming to me?'

Sorqan Šira said, 'At heart I felt full confidence in you, but how could I make haste? Had I hurried and come to you earlier, my Tayiči'ut masters would have blown to the winds, like hearth-ashes, ${ }^{2}$ my wife and children, and the cattle and provisions I had left behind. Because of this I did not hurry, but now that the Tayiči'ut have been defeated we came in haste to join our Qa'an.' When he had finished speaking, Činggis Qa'an said, 'You did right!'

147 Again Činggis Qa'an spoke, saying 'When we fought at Köyiten and, pressing on each other, were reforming our ranks, from the top of those ridges an arrow came. Who, from the top of the mountain, shot an arrow so as to sever the neckbone of my tawny war horse with the white mouth?'

1 Lit., 'Činggis Qa'an.'

2 Cf. above, $\$ \S 87$ and 112 . 
To these words Jebe said, 'It was I who shot the arrow from the top of the mountain. If now I am put to death by the Qa'an, I shall be left to rot on a piece of earth the size of the palm of a hand, but if I be favoured,

For the Qa'an I will charge forward

So as to rend the deep water,

So as to crumble the shining stone.

For him I will charge forward

So as to split the blue stone

In the place which I am told to reach,

So as to crush the black stone

At the time when I am told to attack.'

Činggis Qa'an said, 'A man who used to be an enemy, when it comes to his former killings and hostile actions "conceals his person and hides his tongue" - he is afraid. As for this one, however, he does not hide his killings and hostile actions; on the contrary, he makes them known. $\mathrm{He}$ is a man to have as a companion. He is named Jirqo'adai, but because he shot an arrow at the neckbone of my tawny war horse with the white mouth, I shall call him J̌ebe ${ }^{1}$ and I will use him as my jebe arrow.' He named him J̌ebe and said, 'Keep by my side!'

This is the way in which Jebe came from the Tayiči'ut and became a companion of Činggis Qa'an.

1 Jebe means 'weapon', but it also designated a particular type of arrow. 


\section{THE SECRET HISTORY OF THE MONGOLS}

\section{CHAPTER FIVE}

148 When, on that occasion, Činggis Qa'an plundered the Tayiči'ut, he wiped out the men of Tayiči'ut lineage, such as the Tayiči'ut A'uču Ba'atur, Qoton Örčeng ${ }^{1}$ and Qudu'udar - he blew them to the winds like hearth-ashes, even to the offspring of their offspring. Činggis Qa'an carried away the people of their tribe, and spent the winter at Quba Qaya. ${ }^{2}$

149 Old Širgü'etü of the Ničügüt Ba'arin tribe, together with his sons Alaq and Naya'a, seized Tarqutai Kiriltuq, chief of the Tayiči'ut, who was hiding in the woods, because he was a mortal enemy of Činggis Qa'an. As Tarqutai could not mount a horse, ${ }^{3}$ they made him ride in a cart.

As Old Širgü'etü and his sons Alaq and Naya'a were proceeding thus, holding down Tarqutai Kiriltuq, the sons and younger brothers of Tarqutai Kiriltuq said, 'Let us take him away from them!' They approached and overtook them. When his ${ }^{4}$ sons and younger brothers caught up, Old Širgü'etü got onto the cart and, sitting astride Tarqutai, who was lying on his back and unable to stand up, drew a knife and said, 'Your sons and younger brothers have come to take you away. Even if I do not kill you, telling myself that I am laying hands on my lord, ${ }^{5}$ they will surely kill me saying that I did lay hands on my lord. And if I do kill you, I shall of course be killed all the same. So, at the very moment I die, I shall die taking you as my death-companion. ${ }^{6}$

1 The Qodun Örčeng of $\S 141$ above.

2 I.e., 'Reddish Rock' (tu.)

3 Because of his corpulence. The epithet Tarqutai means 'Fat.'

4 I.e., Tarqutai's.

5 Lit., 'qan.'

6 Lit., 'pillow.' For the idiom 'to die taking [someone as] a pillow', see RSH 1.544. 
Thus saying he straddled him and was about to cut his throat with his big knife, when Tarqutai Kiriltuq, calling loudly to his younger brothers and sons, said, 'Śirgü' etü is killing me. Once he has killed me, what will you achieve by taking away my dead and lifeless body? Draw back at once before he kills me! Temüjin will not kill me. When Temüjuin was still little, because

He had fire in his eyes,

He had a light in his face,

and because he had been abandoned in a camp without a master, ${ }^{1}$ I went there to get him and brought him back home with me:

Saying that if I taught him

He would be likely to learn,

I kept teaching and instructing him just as if

He was a two or three-year-old new colt

I had been training. ${ }^{2}$

Had I wanted to make him die,

Would I not have been able to kill him?

They say that at present

He is becoming thoughtful in his actions,

That his mind is clear. ${ }^{3}$

Temüjin will not cause me to die. You, my sons and younger brothers, quickly turn back at once lest Širgü'etü kills me.' So he cried out loudly.

Tarqutai's sons and younger brothers conferred among themselves: 'We came to save father's life. Once Širgü'etü has deprived him of his life, what can we do with his empty, lifeless body? Better to turn back at once before he kills him!' So saying, back they turned. Alaq and Naya'a, the sons of Old Širgü' etü who had withdrawn on their arrival, ${ }^{4}$ now returned. Širgü'etü, having waited for them to come back, moved on together with his sons.

Because his father Yisügei Ba'atur was dead at the time.

This is Tarqutai's justification of the episode told in $\S 79 \mathrm{ff}$.

Lit., 'opening.'

4 I.e., when Tarqutai's sons and brothers had come up and overtaken them. 
As they proceeded on their way, on reaching the Qutuqul Bend ${ }^{1}$ Naya'a then said, 'If we arrive holding this Tarqutai captive, Činggis Qa'an will say of us that we came having laid hands on our rightful lord. Činggis Qa'an will say of us, "How trustworthy a people are these who come having laid hands on their rightful lord? How can they still be companions to us? They are people who are not worthy of companionship. People who lay hands on their rightful lord must be cut down!" Shall we not be cut down? Better to free Tarqutai and send him away from here, and go to Činggis Qa'an saying, "We, possessing only our bodies, have come to offer our services to Činggis Qa'an." We shall say, "We had seized Tarqutai and were on our way here, but we could not do away with our rightful lord. Saying to ourselves, 'How can we make him die before our very eyes?', we freed him and sent him away, and we have come trustingly to offer our services."”

So he spoke and the father and sons, having approved these words of Naya'a, set Tarqutai Kiriltuq free and sent him away from Quduqul Bend.

When this same Old Širgü'etü arrived with his sons Alaq and Naya'a, Činggis Qa'an asked why they had come. Old Širgü'etü told Činggis Qa'an, 'We seized Tarqutai Kiriltuq and were on our way here, but then saying to ourselves, "How can we make our rightful lord die before our very eyes?", we could not do away with him. We set him free and sent him off, and came to Činggis Qa'an to offer our services.'

At that, Činggis Qa'an said, 'If you had come having laid hands on your lord Tarqutai, you and your offspring would have been cut down as people who had laid hands on their rightful lord. Your thought that you could not do away with your rightful lord is correct.' So saying, he showed favour to Naya'a.

150 After that, when Činggis Qa'an was at Dersüt, ${ }^{2}$ Jaqa

1 Qutuqul $=$ Quduqul below.

2 = Deresüt? The text has Tersüt. See RSH 1.547-48. 
Gambu of the Kereyit came to join him as a companion. ${ }^{1}$ When he arrived, the Merkit were approaching to fight. Činggis Qa'an, Jaqa Gambu and other chiefs engaged them and drove them back. Then, Jaqa Gambu made the Tümen Tübegen and the Olon Dongqayit, two scattered tribes of the Kereyit, also come and submit to Činggis Qa'an.

As for Ong Qa' ${ }^{2}{ }^{2}$ of the Kereyit, previously - in the time of Yisügei Qa'an ${ }^{2}$ - because they were living together very harmoniously, he and Yisügei Qan had declared themselves sworn friends.

The manner in which they had declared themselves sworn friends was as follows:

Because Ong Qan had killed the younger brothers of his father Qurčaqus Buyiruq Qan, he had become a rebel towards his paternal uncle Gür Qan and was forced to sneak away through the Qara'un Gorge ${ }^{3}$ to escape from him. With only a hundred men he got out of the gorge and joined ${ }^{4}$ Yisügei Qan. Prompted by his coming to him, Yisügei Qan moved his own army into the field and, driving Gür Qan toward Qašin, he took Ong Qan's people and returned them to him. This is why they became sworn friends.

151 After that, when Ong Qan's younger brother Erke Qara was about to be killed by his elder brother Ong Qan, he escaped and submitted to Inanča Qan of the Naiman. Inanča Qan dispatched his troops, but Ong Qan in his wanderings had already passed three cities and had made his way to the gür qan of the Qara Kidat. ${ }^{5}$ From there, having rebelled against the gür qan, he passed through the cities of the Uyiqut and the Tangqut. ${ }^{6}$ He fed himself on

1 I.e., as a nökör.

2 For Qa'an read Qan. Nowhere else in the Secret History are these men given the inappropriate title $Q a^{\prime}$ an, so this was certainly a later editorial or scribal error.

3 Lit., 'Dark Gorge.'

4 Lit., 'came to.'

$5 \sim$ Qara Kitat. Cf. below, $\S \S 248$ and 266.

$6 \sim$ Ui'ut and Tang'ut, i.e. the Uighurs and the Tanguts. Cf. below, $\S 152$. 
the way by milking five goats, muzzling their kids, ${ }^{1}$ and by bleeding his camel.

While in these straits, he came to Lake Güse'ür. Činggis Qa'an, on account of Ong Qan and Yisügei Qan having formerly declared themselves sworn friends, sent to him as envoys Taqai Ba'atur and Sükegei J̌e'ün; then, from the source of the Kelüren River, Činggis Qa'an went in person to meet him. Because Ong Qan had arrived starved and exhausted, Činggis Qa'an raised taxes for him, brought him into the camp and took care of him.

That winter, in an orderly way they moved to new pastures and Činggis Qa'an wintered at Quba Qaya.

152 Then Ong Qan's younger brothers and the chiefs said among themselves,

'Our elder brother the Qan

Has a miserable nature; he goes on

Harbouring a rotten liver. ${ }^{2}$

He has destroyed his brothers and has even submitted to the Qara Kidat - and he makes his people suffer. Now, what shall we do with him? To speak of his early days, when he was seven years old the Merkit carried him off; they gave him a kidskin coat with black spots to wear, and in the Bu'ura Steppe by the Selengge River he pounded grain in a Merkit's mortar. But his father Qurčaqus Buyiruq Qan raided the Merkit and there and then rescued his son. And again, when he was thirteen years old, Ajai Qan of the Tatar carried him off together with his mother. When Ajai Qan made him look after his camels, he took with him a shepherd of Ajai Qan and fled back home. After that, he fled again for fear of the Naiman and went to the gür qan of the Qara Kidat on the Čui River, in the country of the Sarta'ul. Then, in less than a year, he rebelled and left once more. He skirted the country of the Ui'ut and the Tang'ut. ${ }^{3}$ Reduced to straits as he went on, he fed himself by milking five goats, muzzling their kids,

${ }^{1}$ In order to prevent them from suckling the she-goat too often. See RSH 1.556-57.

${ }^{2}$ I.e., he has a foul character.

${ }^{3}$ See above, $\S 151$ and n. 6 . 
and by bleeding his camel. He had only a blind yellowish-white horse with a black tail and mane. Being in these straits, he came to his son Temüjin, who raised taxes and indeed took care of him. Now, forgetting that he kept himself alive like this thanks to his son Temüjin, he goes on harbouring a rotten liver. ${ }^{1}$ What shall we do with him?'2

So they said among themselves, and their words were reported by Altun Ašuq to Ong Qan. Altun Ašuq said, 'I too did take part in this scheme, but I could not do away with you, my Qan.' Then Ong Qan had his younger brothers and chiefs arrested: El Qutur, Qulbari, Alin Taiši and the others who had thus conspired. From among his younger brothers, only J̌aqa Gambu escaped and submitted to the Naiman.

Ong Qan had them brought in fetters into his tent and said to them, 'What did we pledge to each other when we passed by the country of the Ui'ut and the Tang'ut? How could I think like you? ${ }^{3}$ So saying, spitting in their faces, he had them freed from their fetters. After they had been spat on by the Qan himself, the people who were in the tent all rose and spat on them.

153 After having spent that winter (1201-1202) at Quba Qaya, in the autumn of the Year of the Dog (1202), Čnggis Qa'an engaged these Tatars in battle at Dalan Nemürges: ${ }^{4}$ the Ča'a'an Tatar, ${ }^{5}$ Alči Tatar, Duta'ut [Tatar] and Aruqai Tatar. Before fighting, Činggis Qa'an jointly ${ }^{6}$ issued the following decree: 'If we overcome the enemy, we shall not stop for booty. When the victory is

1 I.e., an evil mind (= evil intentions).

2 A rhetorical question implying that they should kill him, as evident from what follows.

3 I.e., 'I could never think of you as you did with regard to me!' implying that, were that so, he would execute them.

4 I.e., 'Seventy Felt Cloaks.'

5 = Čaqān Tatar. See RSH 1.566.

${ }^{6}$ I.e., in concert with the other army commanders, such as Altan, Qučar and Dāritai. 'Decree' here translates jasag, also 'law' (in a specific or general sense); for Mongol law in general see RSH 1.567-68 and 3.95-97. 
complete, that booty will surely be ours, and we will share it among ourselves. If we are forced by the enemy to retreat, let us turn back to the point where we began the attack. Those men who do not turn back to the point where we began the attack shall be cut down!' So he decreed with them.

They fought at Dalan Nemürges and drove off the Tatars. After they had overcome them, they forced them to rejoin their ${ }^{1}$ tribe on the Ulqui Šilügelyit River and thoroughly plundered them. There and then they destroyed these important people: the Ča'ān Tatar, ${ }^{2}$ Alči Tatar, Duta'ut Tatar and Aruqai Tatar.

As for the words of the decree that had been jointly issued, since Altan, Qučar and Dāritai - all three - had not complied with them and had stopped for booty, Cinggis Qa'an, saying that they had not complied with these words, sent Jebe and Qubilai to take away from them the herds of horses and the goods they had acquired as booty - everything they had seized.

154 Having destroyed and thoroughly plundered the Tatars, Činggis Qa'an held a great council with his kinsmen in a single tent to decide what to do with the Tatar tribesmen. Together they decided as follows:

'From olden days the Tatar people

Have destroyed our fathers and forefathers;

To avenge our fathers and forefathers,

And requite the wrong, for them

We shall measure the Tatars against the linchpin of a cart,

And kill them to the last one,

We shall utterly slay them. ${ }^{3}$

The rest we shall enslave:

Some here, some there, dividing them among ourselves!'

The council being concluded, as they emerged from the tent, the Tatar Yeke Čeren asked Belgütei what

${ }^{1}$ I.e., the Tatar.

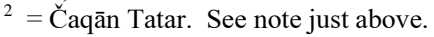

${ }^{3}$ Only those taller than the linchpin would be killed. 
decision they had made. Belgütei said, 'We have decided to measure you all against the linchpin of a cart and slay you.'

At these words of Belgütei, Yeke Čeren issued a proclamation to his Tatars, and they raised a barricade. As our soldiers tried to surround and attack the Tatars that had barricaded themselves in, they suffered great losses. After much trouble, when they forced the barricaded Tatars into submission and were about to slay them to the last man by measuring them against the linchpin of a cart, the Tatars said among themselves, 'Let everyone put a knife in his sleeve and let us die each taking an enemy with us as a death-companion!' ${ }^{\prime}$ And again we suffered great losses. In this way the Tatars were finally measured against the linchpin of a cart and exterminated.

Then Činggis Qa'an issued this order: 'Because Belgütei divulged the decision we took together with our kinsmen at the great council, our soldiers suffered great losses. From now on Belgütei shall not join us in great councils; until the council ends, he shall handle those who are outside and, having dealt with them, he shall judge litigations and those guilty of theft and falsehood. ${ }^{2}$ When the council is over and after we have drunk the ceremonial wine, only then shall Belgütei and Da' aritai $^{3}$ join us!' So he ordered.

155 Then, on that occasion, Činggis Qa'an took as wife Yisügen Qatun, daughter of the Tatar Yeke Čeren. Being loved by him, Yisügen Qatun said, 'If it pleases the Qa'an, he will take care of me, regarding me as a human being and a person worth keeping. ${ }^{4}$ But my elder sister, who is called Yisuii, is superior to me: she is indeed fit for a ruler. Recently, a bridegroom for her was taken into our family as son-in-law. I wonder now where she has gone in all this confusion.'

1 See above, $\$ 149$.

2 See RSH 1.572 for Belgütei's duties, and more broadly for the interesting relationship between him and Činggis.

3 I.e., Dāritai.

${ }^{4}$ I.e., not as something to use and discard. 
On these words Činggis Qa'an said, 'If your elder sister is better than you, let us make a search for her! But if your elder sister comes to hand, will you yield your place to her?' Yisügen Qatun said, 'If it pleases the Qa'an, as soon as I see my elder sister I shall yield to her.'

On this promise, Činggis Qa'an issued the order and had a search made. Our soldiers came across her as she was going into a wood together with the bridegroom to whom she had been given. Her husband fled. They then brought back Yisüi Qatun.

When Yisügen Qatun saw her elder sister, keeping the promise she had made earlier, she rose and let her sit in the place she had occupied. She herself took a lower seat.

Since she turned out to be as Yisügen Qatun had said, Činggis Qa'an was pleased with her; he married Yisüi Qatun and placed her in the rank of his principal wives.

156 After having completely ravaged the Tatars, one day Činggis Qa'an sat outside drinking in company. He was sitting between both Yisüi Qatun and Yisügen Qatun, and was drinking with them, when Yisüi Qatun heaved a deep sigh. Then Činggis Qa'an, having thought it over, summoned Bo'orču, Muqali and other chiefs, and said, 'You' make all these people who have been assembled here and no others - stand in groups of related families, and separate from the rest any man in a group which is not his own.' So he ordered.

As the people were standing thus in groups of related families, a handsome and alert young man stood apart from all the groups. ${ }^{2}$ When they said, 'To which clan do you belong?', that man said, 'I am the bridegroom to whom was given the daughter of the Tatar Yeke Čeren called Yisüi. When we were plundered by the enemy, I took fright and fled. I came hither because things seemed to have settled down now and I kept telling myself, "How can I be recognized among so many people?"'

1 I.e., 'You Bo'orču, Muqali and the other chiefs.'

${ }^{2}$ Because he was a Tatar, and all the adult male Tatar prisoners had been killed $(\$ 154)$. 
When these words were reported to Činggis Qa'an, he ordered: 'All the same, he has been living as an outcast, with hostile intentions; what might he have come to spy upon now? Those like him we have measured against the linchpin of a cart and exterminated. Why hesitate? Cast him out of my sight!' He was cut down immediately.

157 When, in that same Year of the Dog (1202), Cinggis Qa'an rode against the Tatars, Ong Qan rode against the Merkit. Pursuing Toqto'a Beki in the direction of the Barqujin Lowland, Ong Qan killed Tögüs Beki, the eldest son of Toqto'a, seized Toqto'a's two daughters Qutuqtai and Ča'alun and his wives, ${ }^{1}$ and plundered his two sons Qutu and Čila'un together with their people, but of all the booty he gave not one thing to Činggis Qa'an.

158 After that, Činggis Qa'an and Ong Qan rode against Buyiruq Qan of the Gücügüt clan of the Naiman. They reached Soqoq Usun ${ }^{2}$ by the Uluq $\mathrm{Taq}^{3}$ where Buyiruq Qan was staying at the time.

Unable to engage in combat, Buyiruq Qan went off, crossing the Altai Mountains. They pursued Buyiruq Qan from Soqoq Usun and, forcing him to cross the Altai, they chased him along the Ürünggü River downstream at Qum Šinggir. ${ }^{4}$

While this was going on, a chief called Yedi Tubluq, who was patrolling for Buyiruq Qan, was pursued by our patrol. As he was about to flee up the mountain side, his saddle-strap broke and he was captured on the spot. Pursuing Buyiruq Qan down along the Ürünggü River, they overtook him at Lake Kišil Baš, ${ }^{5}$ and there they finished him off.

159 As Činggis Qa'an and Ong Qan were returning from that place, the great warrior Kökse'ü Sabraq of the Naiman arrayed his troops at the Bayidaraq Confluence and prepared to fight them. Činggis Qa'an and Ong Qan

1 The text has Ča'arun for Ča'alun. One should, perhaps, read: 'seized Toqto'a's two wives Qutuqtai and Ča'alun.' See RSH 1.580-81.

2 I.e., 'Soqoq Water (= River).'

3 A mountain already mentioned in $\$ 144$ above. Cf. below, $\$ 177$.

4 Lit., 'of Qum Šinggir (tu. "Sand Promontory").'

5 I.e., 'Red Head' (tu.). 
likewise decided to fight and arrayed their troops; however, when they arrived it was already getting late. They said, 'We shall fight in the morning!', and passed the night in battle order. Then Ong Qan had fires lit in the place where he was stationed and that same night moved upstream along the Qara Se'ül ${ }^{1}$ River.

160 Jamuqa then moved on together with Ong Qan and, as they went, Jamuqa said to Ong Qan, 'My sworn friend Temüjin for a long time has been sending envoys to the Naiman, and now he has not come with us.

Qan, Qan, I am the skylark

That stays in one place;

My sworn friend is

The migratory lark.

He must have gone over to the Naiman and has remained behind intending to submit to them.'

At these words of Jamuqa, Gürin Ba'atur of the Ubčiq $^{2}$ said, 'How can you speak so deceitfully, backbiting and slandering your upright brother?'3

161 Ćnggis Qa'an had spent the night at that same place. Early next morning, at daybreak, he wanted to fight, but when he looked across to Ong Qan's position, he found that he was no longer there. Saying, 'They certainly treat us like burnt offerings at the sacrifice for the dead, ${ }^{4}$ Činggis Qa'an also moved out from there. He crossed the river at the Eder Altai Confluence and, being on the move, proceeded further, setting up camp in the Sa'ari Steppe.

Thereafter, Činggis Qa'an and Qasar, having realised the difficulties of the Naiman, no longer counted them as people to be reckoned with.

162 Kökse'ü Sabraq went in pursuit of Ong Qan. He captured the wife of his son Senggüm together with all his people. He captured also half the people and livestock

1 I.e., 'Black Tail.'

2 The text has Ubčiqtai, but this is probably a mistake for Übčiritei. See RSH 1.586.

${ }^{3}$ Here 'brother' $=$ 'cousin.'

${ }^{4}$ I.e., like something that is no longer useful and can be discarded. 
of Ong Qan which were at Telegetü Pass, ${ }^{1}$ and returned home.

At the time of that engagement, Qutu and Čila'un, the two sons of Toqto'a of the Merkit who were also there, separated from Ong Qan and, taking their own people with them, moved downstream along the Selengge River to join their father.

After being pillaged by Köksegü Sabraq, ${ }^{2}$ Ong Qan sent an envoy to Činggis Qa'an. Through the envoy he sent this message: 'I have been robbed by the Naiman of my people and my wife. I send this envoy to request from you, my son, your "four steeds." 3 Let them rescue my people for me!'

Činggis Qa'an then sent Bo'orču, Muqali, Boroqul ${ }^{4}$ and Čila'un Ba'atur, these 'four steeds' of his, and arrayed his troops. Before the 'four steeds' arrived, Senggüm had just joined battle with Kökse'ü Sabraq at Hula'an Qut ${ }^{5}$ his horse had been shot in the thigh by an arrow and he himself was about to be captured.

At that moment those 'four steeds' arrived and saved him, and they recovered his people and his wife for him all of them. Ong Qan then said, 'Formerly his good father ${ }^{6}$ had saved my people who had been lost like this; now, once more, his son, by sending his "four steeds", has rescued my lost people for me. As to my repaying these favours, let only the protection ${ }^{7}$ of Heaven and Earth decide how, and in what measure!'

164 Ong Qan said further, 'My sworn friend Yisügei Ba'atur once rescued my lost people for me; his son Temüjin has again rescued for me my people who had gone away. When these two, father and son, gathered the lost people and returned them to me, for whose sake did

${ }^{1}$ The Telētü Pass of $\S 136$ above.

2 = Kökse'ü Sabraq.

${ }^{3}$ I.e., the 'four stalwarts.' See RSH 1.591-92.

${ }^{4}=$ Boro'ul. See above, $\$ 137$.

5 I.e., 'Red Cliffs.'

${ }^{6}$ I.e., Činggis Qan's late father.

${ }^{7}$ I.e., the protecting powers. 
they take the trouble of gathering and returning them? As for myself, now

I have grown old, and having grown old,

When I shall ascend to the heights -

I have grown ancient, and having grown ancient,

When I shall ascend to the cliffs -

Who will govern all my people?

My younger brothers lack force of character; there is only Senggüm, my one son, but it is as if he did not exist. If I make my son Temüjin the elder brother of Senggüm, I shall have two sons and my mind will be at rest.' Having said this, Ong Qan and Činggis Qa'an met together in the Black Forest by the Tu'ula River and declared themselves father and son. The reason why they declared themselves father and son was because in early days Ong Qan had declared himself a sworn friend of Cinggis $Q a$ 'an's father Yisügei Qan, and by virtue of this fact Činggis Qa'an said that Ong Qan was like a father to him. Such was the reason why they declared themselves father and son. ${ }^{1}$ They made the following promises to each other:

'When we attack the enemy hosts,

We shall attack together as one;

When we chase the cunning wild beasts,

We shall also chase them together as one!'

So they declared. Činggis Qa'an and Ong Qan also promised each other, saying, 'Out of jealousy for us two -

Should a snake with venomous teeth

Provoke discord between us,

Let us not succumb to his provocations.

By talking only mouth to mouth ${ }^{2}$

We shall believe each other!

Should a snake with venomous fangs

Spread slander about us,

Let us not accept his slander.

By explaining only face to face ${ }^{3}$

We shall believe each other!'

1 See above, $\$ 96$.

2 Lit., 'by teeth and mouth.'

3 Lit., 'by mouth and tongue.' 
And, pledging their word, they lived together in mutual affection.

165 'On top of affection let there be more affection!', Činggis Qa' an thought; and requesting the younger sister of Senggüm, Ča'ur Beki, for his son J̌oči he said, 'I shall give in exchange our daughter Qoǰin Beki to Senggüm's son Tusaqa.'

When this request was made, Senggüm, then, imagining himself to be very important, said, 'If a kinswoman of ours goes to them, she would have to stand by the door and only face towards the back of the tent; but if a kinswoman of theirs comes to us, she would sit in the back of

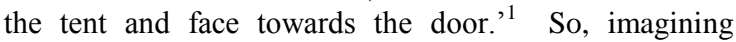
himself to be very important, he spoke disparagingly of us; he was not pleased with our proposition and would not give Ča'ur Beki.

Because of these words, Činggis Qa'an in his heart lost affection for Ong Qan and Nilqa Senggüm.

166 Jamuqa realised that Čnggis Qa'an had in this way lost his affection for them. In the spring of the Year of the Pig (1203), J̌amuqa, Altan and Qučar, Ebügejin and Noyakin of the Qardakin ${ }^{2}$ tribe, To'oril of the Söge'en tribe and Qači'un Beki, all these, having come to an understanding, set out and went to Nilqa Senggüm at Berke Elet, ${ }^{3}$ on the northern side of the Jeje'er Heights.

Slandering Činggis Qa'an, Jamuqa spoke: 'My sworn friend Temüjin has messengers sent with secret communications to Tayang Qan of the Naiman. His mouth is saying "father" and "son", but his behaviour is quite otherwise. Are you going to trust him? If you do not take him by surprise and strike at him, what will become of you? If you move against my sworn friend Temüjin, I will join you and attack his flank!'

${ }^{1}$ The place of honour was, and still is, at the back of the tent facing the door. The least honourable place is next to the door facing the back of the tent. Senggüm says that Ča'ur Beki would be treated like a servant in J̌či's tent, whereas Qojin Beki would expect to be treated like a lady in Tusaqa's tent.

2 Almost certainly a mistake for Qarta'an. See RSH 1.599.

3 I.e., 'Difficult Sands.' 
Altan and Qučar said, 'As for the sons of Mother Hö'elün, for you,

We shall kill the elder brother,

And do away with the younger brother!'

Ebügejin and Noyakin - the two Qarta'at - said, 'For you,

We shall seize his hands,

And grasp his feet!'

To'oril said, 'The best plan is to go ahead and capture Temuijin's people. If his people are taken away from him and he is left without them, what can he do?'

Qači'un Beki said, 'Prince Nilqa Senggüm, whatever you decide I shall go with you,

To the farthest limit,

To the bottom of the deep!'

167 Having been told these words, Nilqa Senggüm reported to his father Ong Qan those very words through Sayiqan Töde'en.

When he was told this, ${ }^{1}$ Ong Qan said, 'How can you think such things about my son Temüjin? Until now we had him as our support, and if now we harbour such evil intentions towards my son, we shall not be loved by Heaven. Jamuqa has a glib tongue. Is he right in what he says? Is he correct?'2 He was displeased and sent back Sayiqan Töde'en.

Senggüm sent another message saying, 'When any man with a mouth and a tongue says these things, ${ }^{3}$ how can one not believe him?' He sent messages twice, three times, but could not convince Ong Qan. Finally, he went to him in person and said, 'Even now, at a time when you are still so lively and well, Temüjin has not the slightest regard for us. Truly, when you, his father the Qan, will have reached the age when men

Choke on the white milk,

And are stifled by the black meat,

1 Lit., 'these very words.'

2 A rhetorical question implying that he is untrustworthy.

3 I.e., it is common knowledge. See RSH 1.604. 
will he let us govern your people - the people that your father Qurčaqus Buyiruq Qan gathered laboriously in such great number? How will he let anyone govern it?'

At these words, Ong Qan said, 'How can I do away with my child, my son? Because until now he has been our support, is it right to harbour evil intentions against him? We shall not be loved by Heaven.'

At these words, his son Nilqa Senggüm became angry; he pushed off the tent-door and left. But Ong Qan, concerned about losing the affection of his son Senggüm, called him back and said to him, 'Who knows whether we shall be loved by Heaven after all? You say, "How shall we do away with the son?" Just do what you can - it is for you to decide!'

168 Senggüm then spoke with the others and said, 'Those same people requested our Ča'ur Beki. Now, having fixed a day, let us invite them to come and dine at the betrothal feast and, there and then, seize them!' They all agreed and made a compact with Ong Qan to that effect.

They sent word to Činggis Qa'an: 'We shall provide Ča'ur Beki. Come and dine at the betrothal feast!' Činggis Qa'an, being so invited, drew near with ten men. On the way he spent the night in Father Mönglik's tent. Then Father Mönglik said, 'When we requested Ča'ur Beki, those same people despised us and would not provide her. How is it that now, on the contrary, they invite you to dine at the betrothal feast? Why do people who think themselves so important invite you, and contradicting themselves, now say, "We shall provide her"? Are they right? Are they correct? ${ }^{2}$ Son, you must proceed with caution. Let us send a message giving as an excuse that it is spring, our herds are lean, and we must fatten our horses first.'

Činggis Qa'an did not proceed, but sent Buqatai and Kiratai telling them to dine at the betrothal feast in his place; then from the tent of Father Mönglik he returned home.

\footnotetext{
I.e., with Temüjin.

2 I.e., they are not trustworthy. See above, $\S 167$, n. 2.
} 
When Buqatai and Kiratai arrived, Senggüm and the others said, 'We have been found out. Early tomorrow we shall surround and capture them!'

169 Having thus pledged their word that they would surround and capture them, Altan's younger cousin, Yeke Čeren, said when he came home, 'We have decided to capture Temüjin early tomorrow. What sort of a reward might be expected by someone who delivers a message with this news to Temüjuin?'1

When he spoke in this way, his wife Alaq It said, 'What is this idle talk of yours? Some people here might take it seriously!' As they were so conversing, their horse-herder Badai came to bring in the milk; he overheard this conversation and withdrew.

After leaving the tent Badai reported to his companion, the horse-herder Kišiliq, the words Yeke Čeren had spoken. Kišiliq said, 'I too shall go and find out the truth of it', and went to Yeke Čeren's tent. Yeke Čeren's son, Narin Ke'en, was sitting outside, sharpening his arrows. He said, 'Whatever were we talking about a short while ago? We should have had our tongues taken out! Whose mouth can we now stop from repeating it?'

Having spoken thus, Narin Ke'en also told Kišiliq, his horse-herder, 'Fetch and bring in ${ }^{2}$ the white Merkit horse and the bay with the white muzzle, and tether them: tonight, towards daybreak, we'll ride out to attack.' So he said.

Kišiliq left and told Badai, 'I have checked what you said a short while ago. It is true. Now the two of us will go and take the news to Temüjuin.' Having both agreed, they brought in the white Merkit horse and the bay with the white muzzle, and tethered them. That very evening, in their travel-tent they killed one of their lambs and cooked it with their bedboards as fuel. Then they mounted on the white Merkit horse and the bay with the white muzzle that were tethered ready, and set off into the night.

1 I.e., the reward was certain to be handsome.

2 From the pasture. 
That night they reached Činggis Qan's camp. From the back of his tent Badai and Kišiliq reported the words spoken by Yeke Čeren, and what his son Narin Ke'en had said when he was sitting, sharpening his arrows: 'Fetch and tether the two geldings, the white Merkit horse and the bay with the white muzzle' - all the words that had been said they reported for Činggis Qan to know. Badai and Kišiliq also spoke, saying, 'If Činggis Qa' an favours us with his trust, he will not hesitate to act: they have pledged to surround and capture you.' 


\section{THE SECRET HISTORY OF THE MONGOLS}

\section{CHAPTER SIX}

170 On this intelligence Činggis Qa'an believed the words of Badai and Kišiliq; that same night he informed the trusted men who were at his side and, abandoning his baggage to lighten his train, set out and fled in the night.

Proceeding by way of the northern side of Ma' ${ }^{1}$ Heights, he left behind J̌elme Qo'a of the Uriangqai, for he trusted him, as his rearguard on the northern side of Ma'u Heights. He set up patrols and moved on. As he continued his advance, at noon of the following day he reached Qalaqalyit Sands, where he halted to rest and eat, waiting for the sun to set.

While they rested and ate, Čigidei and Yadir, the horse-herders of Alčidai, led their geldings to pasture, some here and some there, on the fresh grass. As they moved about, they saw the dust raised by the enemy coming in pursuit, passing by Hula'an Burqat ${ }^{2}$ on the southern side of Ma'u Heights. 'The enemy has arrived,' they said and came back driving the geldings before them.

When they were told that the enemy had arrived, they all looked out and observing the dust raised by the enemy passing by Hula'an Burqat on the southern side of Ma'u Heights, they said, 'That is Ong Qan coming in hot pursuit'. Then Činggis Qa'an, having seen the dust, had his geldings brought in, ${ }^{3}$ loaded them, and rode off with his followers. If on that occasion these two herdsmen had not noticed the enemy's approach, he would have been caught unprepared.

As they approached, Jamuqa was advancing together with Ong Qan. While they advanced Ong Qan there and then asked Jamuqa, 'Who are those with son Temüjin

${ }^{1}$ Written Mau for Ma'u ('Evil') throughout. See RSH 1.615-16.

2 I.e., 'Red Willows.'

${ }^{3}$ From the pastures. 
who are likely to fight?' To his question Jamuqa said, 'There are his people called the Uru'ut and the Mangqut; those people of his do indeed know how to fight:

Every time they turn about,

Their battle array holds;

Every time they wheel round, too,

Their ranks hold.

Those people are accustomed to swords and spears from childhood. They have black and multicoloured standards - they are the people of whom we must be wary!'

On these words Ong Qan said, 'If this is so, Qadaq, the leader of our brave Jirgin, shall meet them: we shall send our brave Jirgin to the attack. We shall have Ačiq Širun of the Tümen Tübegen attack next in support of the Jirgin. The brave Olon Dongqayit we shall send to attack in support of the Tümen Tübegen. Qori Šilemün Taiši in support of the Olon Dongqayit shall attack at the head of $m y$ - the Ong-qan's - thousand bodyguards. In support of the thousand bodyguards we, the main body of the army, shall move to the attack.' Ong Qan also said, 'Younger brother J̌amuqa, you set our troops in battle array!'

At these words Jamuqa drew apart and told his companions, 'Ong Qan tells me to set these troops of his in battle array, but I have never been able to fight against my sworn friend. For Ong Qan to say that I should set these troops in battle array means that he is less capable than I am. Not much of a companion, is he! Let us send word to my sworn friend to be on his guard.'

So Jamuqa secretly sent the following message to Činggis Qa'an: 'Ong Qan asked me, "Who are those with son Temüjin who are likely to fight?" To his question I said, "I rate first the Uru'ut and the Mangqut." Thus I spoke, and at these words of mine those same Jirgin were ordered to the forefront as vanguard. Ačiq Širun of the Tümen Tübegen was appointed to support the Jirgin. [The Olon Dongqayit were appointed to support the Tümen Tübegen.] Qori Šilemün Taiši, leader of the thousand bodyguards of Ong Qan, was appointed to 
support the Olon Dongqayit. For his ${ }^{1}$ support, they decided that the main body of Ong Qan's own army should stand in readiness. Ong Qan also told me: "Younger brother Jamuqa, you set these troops of mine in battle array!", saying that he relied on me. From this I realized that he is not much of a companion. How can I set his troops in battle array for him? I have never been able to fight against my sworn friend, and Ong Qan is less capable than me. Sworn friend, do not be afraid; be on your guard!' That was the message he sent.

171 When Činggis Qa'an received this news he said, 'Uncle Jürčedei of the Uru'ut, let us make you the vanguard; what do you say?' Before Jürrčedei could utter a word, Quyildar Šečen of the Mangqut said, 'I shall fight in front of $m y$ sworn friend! As for how one shall afterwards take care of my orphaned children, $m y$ sworn friend will decide.' Jürčedei then said, 'Let us, Uru'ut and Mangqut, fight as vanguard in front of Činggis Qa'an!'

So saying, Jürčedei and Quyildar arranged themselves in battle order in front of Činggis Qa'an with their Uru'ut and Mangqut troops. As they stood thus, the enemy arrived with the Jirgin as vanguard. When they came forward, the Uru'ut and the Mangqut rushed against them and overcame the Jirgin. As they advanced, crushing them, Ačiq Širun of the Tümen Tübegen charged ahead. ${ }^{2}$ In the attack, Ačiq Širun stabbed Quyildar and brought him off his horse. The Mangqut turned back and stood guard over Quyildar.

Jürčedei then went on the attack with his Uru'ut troops and overcame the Tümen Tübegen. As he advanced, crushing them and driving them back, the Olon Dongqayit charged against him, but Jürčedei crushed also the Dongqayit. After overcoming them, as he went forward, Qori Šilemün Taiši attacked him with the thousand bodyguards. When J̌üčedei had also repulsed and defeated Qori Šilemün Taiši and was pressing ahead,

1 I.e., Qori Šilemün Taiši’s.

2 In support of the Jirgin who were being overcome by the Uru'ut and the Mangqut. 
Senggüm, without permission from Ong Qan, began to charge against him, but was shot by an arrow in one of his bright red cheeks. Senggüm fell there and then from his horse. When Senggüm fell all the Kereyit turned back and stood guard over him.

Having defeated them, when the setting sun touched the hilltops our troops withdrew, taking back with them Quyildar who had fallen from his horse wounded.

Činggis Qa'an and our men moved away from Ong Qan - from the place where they had fought each other. They set out in the evening and spent the night some distance from there.

172 They spent the night standing in battle order. At daybreak, when they held a roll-call, Öködei, ${ }^{1}$ Boroqul and Bo'orču were not there. Čnggis Qa'an said, 'Bo'orču and Boroqul as true friends have remained behind with Öködei. How could they part from each other, whether living or dying?'

When night came, our men, having brought in their geldings, ${ }^{2}$ spent the night in readiness. Saying, 'If the enemy pursues us we shall fight,' Činggis Qa'an arranged the troops in battle order.

When the day grew light, they beheld a man approaching from the rear. As he drew nearer it turned out to be Bo'orču. Having let Bo'orču come closer Činggis Qa'an beat his breast and said, 'Let Eternal Heaven decide what should be!'

Bo'orču said, 'When we went on the attack my horse was shot by an arrow and fell under me. I ran away on foot and as I was going like this, those same Kereyit, having turned back, stood guard over Senggüm; in the fighting's lull, I noticed a pack-horse standing there whose pack had slipped on its side. I cut off its pack, got on the pack-saddle and came away. Following the tracks left by our men when they withdrew from the battlefield, I went on, found them and here I am.'

$1=$ Ögödei.

2 From the pastures. 
173 Then, a moment later, another man approached. He advanced and drew closer, his feet dangling under him; ${ }^{1}$ yet, when one looked, it seemed like a single person riding. When he came up and drew to a halt, it was Boroqul mounted double behind Öködei with blood trickling from the corners of his mouth.

Öködei had been hit by an arrow in the neck vein; as the blood was clotting, Boroqul had sucked the woundclogging blood, letting it trickle from the corners of the mouth: that's how he came.

When Činggis Qa'an saw this, tears fell from his eyes and his heart was pained. He speedily ordered a fire to be prepared, had the wound cauterized, and drink sought for Öködei and given to him. 'If the enemy comes after us, we shall fight him!', he said.

Boroqul said, 'The dust raised by the enemy has shifted in the opposite direction towards Hula' an Burqat on the southern side of Ma'u Heights - rising in a long trail, the dust has moved away in the opposite direction.'

At these words of Boroqul, Činggis Qa'an said, 'Had he come after us, we would have fought him; but if we are now witnessing the enemy take flight, we shall regroup our troops and fight him later!' So saying, he departed. After he left, he moved upstream along the Ulqui Šilügelǰit River and came into Dalan Nemürges.

174 Then, from the rear, ${ }^{2}$ Qada'an Daldurqan came up, leaving behind his wife and children. When he arrived, Qada'an Daldurqan reported Ong Qan's words saying, 'When Ong Qan's son Senggüm was shot in one of his bright red cheeks by an učumaq arrow and fell from his horse, and the Kereyit turned back and stood guard over him, Ong Qan then said:

"When it would have been better

Not to stir him up,

We did stir him up;

When it would have been better

1 I.e., as if someone else was riding.

2 I.e., after Činggis Qan - to join him. 
Not to provoke him,

We did provoke him - thus, alas,

We have been the cause of their driving

A nail into my son's cheek.

But having arrived in time to save my son's life, let us now together rush against them!" Thus he spoke and Ačiq Širun said to him, "Qan, Qan, desist! Pleading for a son who was yet to come, we made magic strips and uttered the prayer A6ui 6a6ui - we prayed, pleading for him. So at last your son Senggüm was born, let us take care of him! Most of the Mongols are on our side, with J̌amuqa, and with Altan and Qučar. As for the Mongols who have rebelled against us and who left with Temüjin, where can they go? They are those

Who have but a horse as a mount,

Who have but a tree as a shelter.

If they do not come and join us of their own accord, we shall go out, wrap them up like dry horse dung in a skirt, and bring them here!" To these words of Ačiq Šrun, Ong Qan said, "Correct! If this is so, I fear my son may be exhausted. Take care of my son, and do not shake him while you carry him!" Having said this he withdrew from the battlefield and returned home'. So spoke Qada'an Daldurqan.

175 Then Činggis Qa'an departed from Dalan Nemürges following the course of the Qalqa River downstream, and counted his forces. When numbered, there were two thousand six hundred men. With one thousand three hundred men Činggis Qa'an moved along the western bank of the Qalqa while the Uru'ut and Mangqut moved with one thousand three hundred men along the eastern bank of the Qalqa.

They were moving on in this way, hunting for provisions as they went, when Quyildar, whose wounds had not yet healed, ${ }^{1}$ without paying heed to a warning by Činggis Qa'an rushed after the game. He had a relapse

${ }^{1}$ See above, $\S 171$. 
and died. Činggis Qa'an then buried him at Keltegei Qada, at the Or Bend ${ }^{1}$ of the Qalqa.

176 Cinggis Qa'an, knowing that just where the Qalqa River flows into Lake Buyur there stayed the Onggirat chief Terge Emel and others, sent Jürčedei to them with the Uru'ut troops. When he sent him off he said, 'If they say that the Onggirat, from olden days,

Live thanks to the good looks

Of their granddaughters

And the beauty

Of their daughters, ${ }^{2}$

they will certainly submit to us. If they say that they will oppose us, we shall fight them!'

Because he had been sent with this message, the Onggirat submitted to Jürčedei. As they had submitted peacefully, Činggis Qa'an did not touch anything of theirs.

177 Then, after having obtained the Onggirat's submission, Činggis Qa'an departed and, pitching camp east of Tüngge Stream, he gave Arqai Qasar and Sügegei J̌e'ün a verbal message to be delivered to Ong Qan, saying, 'Tell this to my father the Qan: "We have pitched camp east of Tüngge Stream; the grass is good and our geldings have gained strength."' He further said, 'My father the Qan, out of what grievance did you frighten me? If you must frighten me, why don't you frighten me in such a way at least as to let your poor sons and poor daughters-in-law sleep to their heart's content? ${ }^{3}$

Bringing down the couch on which they sat

According to their rank,

Scattering the smoke that rose upwards

From their tents,

1 Or 'at the slanting cliff of the Or Bend of the Qalqa.' See RSH 1.633-34.

2 Cf. above, $\$ 64$.

3 In view of Ong Qan's adoption of Činggis Qa'an as his son (see above, §164), by 'poor sons' and 'poor daughters-in-law' are meant Činggis' own brothers and sisters-in-law. If Činggis is to be blamed for something, why should they be involved too? 
Why have you frightened them so? My father the Qan,

Have you been stung

By someone standing at the side?

Have you been stirred up

By someone coming between us? ${ }^{1}$

My father the Qan, what did we agree upon, the two of us? At Hula'anu'ut Bolda'ut of Jorqal Qun did we not say to each other that

Should a snake with venomous teeth

Provoke discord between us,

Let us not succumb to his provocations.

By explaining only mouth to mouth ${ }^{2}$

We shall believe each other! ${ }^{3}$

Did we not agree to this? And now, my father the Qan, when you parted from me, did you explain mouth to mouth? ${ }^{4}$

Should a snake with venomous fangs

Spread slander about us,

Let us not give in to his slander.

By explaining only face to face ${ }^{5}$

We shall believe each other! ${ }^{6}$

Did we not agree to this? And now, my father the Qan, when you separated from me, did you explain face to face? My father the Qan, even if I and my followers are few in number, I gave you no cause to seek for a more numerous group; even if I am bad, I gave you no cause to seek for someone better. If a two-shaft cart breaks the second shaft, the ox cannot pull it. Like that, was I not also your other shaft? If a two-wheel cart breaks the second wheel, it cannot move. Like that, was I not also your other wheel? If we speak of former days, after your father Qurčaqus Buyiruq Qan you became qan surely

1 Cf. above, $\$ 127$, and below, $\$ 201$.

2 Lit., 'by teeth and mouth.'

3 Cf. above, §164. For Hula'anu'ut Bolda'ut of Jorqal Qun ('Red Hills of Deer [?] Cliff'), see RSH 1.638.

4 Lit., 'by teeth and mouth.'

5 Lit., 'by mouth and tongue.'

${ }^{6}$ Cf. above, $\$ 164$. 
because you were the eldest of forty sons. When you became qan you killed your two younger brothers Tai Temür Taiši and Buqa Temür; when your younger brother Erke Qara was about to be killed too, he escaped, saving his life, and submitted to Inanča Bilge Qan of the Naiman. Because you had become the murderer of your younger brothers, your paternal uncle Gür Qan moved against you. When he came upon you, you saved your life by fleeing with a hundred men; you escaped following the Selengge River downstream and sneaked away through the Qara'un Gorge. ${ }^{1}$ Then, when you got out of there, you gave your daughter Huja'ur Üjin in marriage to Toqto'a of the Merkit to please him. ${ }^{2}$ Having got out from the Qara'un Gorge you came to my father Yisügei Qan and there and then said to him: "Rescue my people for me from my uncle Gür Qan." Approached by you in that manner, my father Yisügei Qan took with him Qunan and Baqaj̄i from the Tayiči'ut. Saying, "I shall rescue your people for you," he arrayed his troops and set out. He pursued Gür Qan, who was at Qurban Telesüt, and twenty or thirty of his men towards Qašin; he rescued your people for you. From there you came to the Black Forest by the Tu'ula River and you, my father the Qan, became a sworn friend of Yisügei Qan. Then, Ong Qan my father, you gratefully said, "As for the favour of this good action of yours, I will repay your favour even to the children of your children - let only the protection of Heaven Above and Earth decide how, and in what measure!"3 You spoke thus and were grateful.

'After that Erke Qara ${ }^{4}$ requested troops from Inanča Bilge Qan of the Naiman and moved against you. When he came upon you, you saved your life by abandoning your own people and, fleeing with a few men, you went to the gür qan of the Qara Kidat on the Čui River, in the country of the Sarta'ul. In less than a year you rebelled

1 Cf. above, $\$ 150$.

2 I.e., to establish friendly relations with the Merkit.

3 Cf. $\$ 163$ ad fin.

4 Written Erge Qara. Cf. §151. 
against the gür qan and departed once more. Reduced to straits as you went through the country of the Ui'ut and the Tang'ut, ${ }^{1}$ you fed yourself by milking five goats, muzzling their kids; you fed yourself also by bleeding your camel, and came to me with only a blind yellowishwhite horse with a black tail and mane. When I learned that you, my father the Qan, had arrived in such straits, remembering that you and my father Yisügei Qan had formerly declared yourselves sworn friends, I sent as envoys Taqai and Sükegei to meet you; furthermore, from the Bürgi Escarpment on the Kelüren River, I in person went to receive you, and we met at Lake Güse'ür. Since you had arrived in such straits, I levied taxes and gave them to you. Because of your former declaration of sworn friendship with my father, the two of us declared ourselves father and son at the Black Forest by the Tu'ula: is that not the reason why we did it ? $^{2}$

'That winter I brought you into my camp and took care of you. When winter was over and summer had passed, in the autumn I rode against Toqto'a Beki of the Merkit. I fought with him at Mürüče Se'ül by the Qadiqliq ${ }^{3}$ Ridge. I pursued Toqto'a Beki in the direction of the Barqujin Lowland. I plundered the Merkit: I seized their many herds of horses and palatial tents, their grainstores - all - and gave it to you, my father the Qan. Your hunger I did not allow to last until noon, your leanness I did not allow to last until the middle of the month.

'Then we pursued Buyiruq Qan the Güčügür and forced him to cross the Altai from Soqoq Usun by the Uluq Taq; and, going along the Ürünggü River downstream, we finished him off ${ }^{4}$ at Lake Kičil ${ }^{5}$ Baš.

'As we were returning from that place, Kökse'ü Sabraq of the Naiman had arrayed his troops at the

${ }^{1}$ Cf. above, $\$ \$ 151$ and 152.

2 See above, $\$ 151$.

3 = Qadingliq. For these localities see RSH 1.640.

${ }^{4}$ Cf. above, $\S 158$.

5 = Kišil. 
Bayidaraq Confluence and was ready for battle. But, as evening fell, we said, "We shall fight early tomorrow!", and spent the night in battle order. Then you, my father the Qan, had fires lit in the place where you were stationed and in the night moved up along the Qara Se'ül River. When I looked out early next morning, you were no longer in your position; you had moved out. I said, "They certainly treat us like burnt offerings at the sacrifice for the dead," and I moved out too. Crossing the river at the Eder Altai Confluence, I came back and pitched camp in the Sa'ari Steppe. ${ }^{1}$

'Then Kökse'ü Sabraq pursued you and seized the wife and people of Senggüm - all of them. He captured also half the people and livestock belonging to ${ }^{2}$ you, my father the Qan, which were at Telegetï Pass. Qudu ${ }^{3}$ and Čila'un, the sons of Toqto'a of the Merkit, and their people were with you, but at the time of that engagement they deserted you and left, moving into the Barqujin Lowland to join their father. Then you, my father the Qan, sent a message saying, "I have been robbed of my people by Kökse'ü Sabraq of the Naiman; my son, send me your "four steeds.",4 Not thinking the way you do, I there and then sent you Bo'orču, Muqali, Boroqul and Čila'un Ba'atur, these "four steeds" of mine, and arrayed my troops. Before my "four steeds" arrived, Senggüm had just joined battle with Kökse'ü Sabraq at Hula'an Qut; his horse had been shot in the thigh by an arrow and he himself was about to be captured. At that moment, my "four steeds" arrived and saved Senggüm, and they recovered also his wife together with his people for him all of them. Thereupon you, my father the Qan, gratefully said, "My son Temüjin, by sending his 'four steeds', has rescued my lost people for me."5

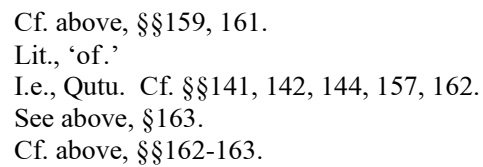


'Now, my father the Qan, out of what grievance do you reprimand me? To explain the nature of this grievance, send me your messengers. When you send them, send Qulbari Quri and Idürgen. ${ }^{1}$ If you do not send both of them, send me at least the latter.'

178 To these words, Ong Qan said, 'Oh! Sinful that I am!

By abandoning my son

I abandoned the norm;

By parting from him

I parted from my duty.'

Pained in his heart, Ong Qan said, 'Now, if I think evil when I see my son, let my blood be shed like this!' And, taking the oath, he pricked the ball of his little finger with his arrow-notching knife, let the blood trickle and poured it into a small birch-bark casket. He sent it by the messenger saying, 'Give this to my son.'

179 Čnggis Qa'an also sent the following verbal message to sworn friend J̌amuqa: 'Because you cannot bear the sight of me, you caused a rift between my father the Qan and me. In the past, the first of us to rise could drink of the blue cup of my father the Qan. As I got up first and drank of it you were jealous. Now you may drain the blue cup of my father the Qan, but how much more will you be able to consume?'

Činggis Qa'an also sent the following verbal message to Altan and Qučar: 'When you rejected me, you two, did you say that you would leave me, breaking with me openly, or did you say that you would leave me after you had consulted only among yourselves? Qučar, when I said that, of all of us, you as the son of Nekün Taiši should become qan, you declined. When I said that you, Altan, should then become qan and govern us like your father Qutula Qan had been governing us, you too declined. And when I said, "You, Sača and Taiču, become the qans," because they were the sons of Bartan Ba'atur ${ }^{2}$ from the senior line, I was unable to obtain their consent.

1 Called Itürgen in $\$ 184$ below.

2 An error for Barqaq Ba'atur. See RSH 2.645-46. 
Because my urging you to become qan had no effect, when I was told by you to be the qan I governed the people. Had you become qan, when as vanguard I would have been sent speeding after many foes, then, with Heaven's protection, while plundering the enemy people,

Maidens and ladies with beautiful cheeks,

And geldings with fine croups, for you

I would have brought.

When ordered to go ahead and round up

Wild beasts in a battue, for you

I would have driven the beasts of the cliffs

Until their forelegs pressed together.

For you I would have driven the beasts of the steep banks

Until their thighs pressed together.

For you I would have driven the beasts of the steppe

Until their bellies pressed together.

'Now, be the good companions of my father the Qan, for I fear people might say that you grow easily tired of your friends. Don't let it be said that your achievements were only $d u e$ to the support of $m e$, the $\check{c} a$ 'ut quri. ${ }^{2}$ And do not let anyone settle at the source of the Three Rivers! ${ }^{3}$ He sent this message.

180 Činggis Qa'an also sent the following verbal message to younger brother To'oril: 'The reason for calling you "younger brother" is this: Once Oqda Bo'ol ${ }^{4}$ was brought as captive by Tumbinai and Caraqai Lingqu. Oqda Bo'ol's son was Sübegei Bo'ol. Sübegei Bo'ol's son was Kököčü Kirsa'an. Kököčü Kirsa'an's son was Yegei Qongtaqar. ${ }^{5}$ You, To'oril, are Yegei Qongtaqar's son. You constantly flatter Ong Qan saying, "I will give you

${ }^{1}$ Cf. above, $\$ 123$.

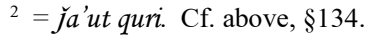

3 I.e. the Onon, the Tūla and the Kerulen. The 'source' of the three rivers is the area of Mount Burqan Qaldun.

${ }^{4}$ I.e., 'Oqda the Slave.'

${ }^{5}=$ Jegei Qongdaqor. See above, $\S 120$. 
people" - whose people? Altan and Qučar are surely not going to let anyone rule my people! The reason for my calling you "younger brother" is that you are

The threshold slave

Of my great-great-grandfather,

The personal door slave

Of my great-grandfather. ${ }^{1}$

Such is my message for you.'

181 Cringgis Qa'an also sent the following verbal message to his sworn friend Senggüm: 'Although I was indeed like a son born clothed and you like a son born naked, ${ }^{2}$ our father the Qan looked after both of us equally; but you, sworn friend Senggüm, drove me out because you were jealous that I might come between you and our father. Now do not pain our father the Qan's heart. Evening and morning, coming in and going out, always be of comfort to him. Do not distress or rend the heart of our father the Qan by saying, without giving up your earlier intentions and while our father the Qan is still alive, that you will become qan!' And he also sent this message: 'Sworn friend Senggüm, send me your messengers. When you send them, send me Bilge Beki and Tödö'en. [If you do not send both of them,] send at least the latter. When you send messengers to me, father the Qan, send two messengers; sworn friend Senggüm, you also send two messengers; sworn friend J̌amuqa, you also send two messengers; Altan, you also send two messengers; Qučar, you also send two messengers; Ačiq Širun, you also send two messengers; Qači'un, you also send two messengers!' And he had these messages conveyed by word of mouth through Arqai Qasar and Sügegei J̌e'ün.

When the messages were delivered in this way, Senggüm said, "When did he ever say "our father the Qan"? Didn't he rather say "the old murderer"? When did he ever call me "sworn friend"? Didn't he rather say that I am like "Toqto'a the shaman wearing the tail of a

1 Cf. $\$ \$ 137$ and 211.

2 I.e., 'I am the adopted son and you the natural son (of Ong Qan).' 
Sartaq sheep" "1? I do understand the scheme behind these words of his: they are the words that precede a fight. You Bilge Beki and Tödö'en raise the war standard and fatten the geldings; there is no time for hesitation!'

And so Arqai Qasar returned from Ong Qan, but because the wife and children of Sügegei J̌e'ün were there with To'oril, ${ }^{2}$ Sügegei J̌e'ün did not have the courage to go with Arqai and stayed behind. When Arqai arrived he reported these words of Senggüm to Činggis Qa'an.

182 Činggis Qa'an then left and pitched camp at Lake Baljuna. When he was about to encamp, he met right there the Qorulas of Čo'os Čaqān. ${ }^{3}$ These Qorulas submitted to him without fighting.

From Alaquš Digit Quri of the Önggüt came Asan ${ }^{4}$ the Sartaq. He had a white camel and was driving a thousand wethers along the Ergüne River downstream in order to buy pelts of sables and squirrels. As he drew in to water his wethers at Lake Baljuna he met Činggis Qa'an.

183 Činggis Qa'an was also watering his animals at the same Lake Balyuna when Qasar, leaving behind his wife and his three sons Yegü, Yisüngge and Tuqu with Ong Qan, departed with his companions - few in number and dispossessed of all but their bodies. Saying, 'I will join my elder brother,' he searched for Činggis Qa'an. He climbed the ridges of Qara'un Jidun, ${ }^{5}$ but he could not find him there; being in dire straits he ate hides and sinews and went on, eventually joining Činggis Qa'an at Lake Baljuna.

Činggis Qa'an received Qasar and rejoiced. They agreed to send messengers to Ong Qan. Through Qali'udar of the Je'üret and Čaqurqan ${ }^{6}$ of the Uriangqai Ćnggis Qa'an sent a message. He told Qali'udar and

1 I.e., somebody to laugh at. See RSH 2.652-54 for this saying.

2 This To'oril is Sügegei's brother mentioned in $\$ 180$ above.

${ }^{3} \mathrm{Cf}$ §141 and note there.

4 = Hasan.

5 I.e., 'Dark (or Black) Ridge.'

$1=$ Ča'urqan. See above, $\$ 120$. 
Ćaqurqan, 'Tell my father the Qan that these are the words of Qasar,' saying:

'I watched for my elder brother

But lost sight of him;

I searched for his tracks

But could not find his trail ${ }^{1}$

I called him but my voice

He did not hear.

I now lie gazing at the stars

I with a clod of earth as my pillow.

My wife and sons are with you, my father the Qan. If, hopefully, I get from you someone I can trust, I will come back to my father the Qan. Tell him that Qasar sent this message!' He also said to them, 'We shall follow close behind you and meet at Arqal Geügi ${ }^{2}$ on the Kelüren River. You must come there!'

Having agreed on the time and place of meeting, Činggis Qa'an forthwith sent Qali'udar and Čaqurqan on their mission. He sent Jürčedei and Arqai ahead to reconnoitre, and at once set forth from Lake Baljuna together with the army. They rode out and arrived at Arqal Geügi on the Kelüren River.

184 Qali'udar and Čaqurqan reached Ong Qan and gave him the verbal message sent from here, ${ }^{3}$ saying, 'It is Qasar's message.' Ong Qan had set up his golden tent of thin woollen cloth and was feasting, not suspecting anything. Upon the words of Qali'udar and Čaqurqan, Ong Qan said, 'If it is so, let Qasar come!' He then said, 'I shall give Itürgen in trust. ${ }^{4}$ And he sent him with them.

And so they came, and as they were reaching the appointed place at Arqal Geügi, the envoy Itürgen seeing the signs of a multitude in the distance, turned back and fled. Qali'udar's horse being swifter, Qali'udar caught up with him, but did not venture to seize him; instead, going now in front of him, now behind him, he kept on

${ }^{1}$ Cf. above, $\S 56$.

2 I.e., 'Dry Dung Hook.' See RSH 2.662-64.

${ }^{3}$ I.e., from Lake Baljuna, by Činggis Qa'an.

${ }^{4}$ I.e., as guarantor, as requested by Qasar. 
obstructing his way. Čaqurqan's horse was slower; at an arrow's shot from the rear, ${ }^{1}$ he hit Itürgen's gold-saddled black gelding on the tip of its rump, so that it sat on its haunches. Qali'udar and Čaqurqan then took Itürgen captive and brought him to Činggis Qa'an. Not speaking to Itürgen, Činggis Qa'an said, 'Take him to Qasar; let Qasar decide how to deal with him!' They took him to Qasar who, without saying a word to him, cut Itürgen down and cast away his body there and then.

185 Qali'udar and Čaqurqan said to Činggis Qa'an, 'Ong Qan is off his guard; he has pitched his golden tent and is feasting. Let us quickly move forward from here and, travelling through the night, let us attack him by surprise and surround him!'

Ciinggis Qa'an approved these words and sent Jürčedei and Arqai ahead to reconnoitre. They travelled through the night and having reached Ong Qan's camp, which was at the J̌er Gorge pass of Jeje'er Heights, they surrounded it.

They fought for three nights and three days, but our men stood firm, surrounding the Kereyit, who on the third day were exhausted and surrendered. Ong Qan and Senggüm escaped during the night - how they did so was not known. One who fought longer than the others was Qadaq Ba'atur of the Jirgin. When he came out to surrender, Qadaq Ba'atur said, 'We fought three nights and three days. I said to myself, "How can I let my rightful lord ${ }^{2}$ be seized and killed before my eyes?" Unable to forsake him, I struggled and kept on fighting so that he could escape and save his life. Now, if I shall be made to die, I shall die, but if Činggis Qa'an favours me, I will serve him.'

Činggis Qa'an approved Qadaq Ba'atur's words, saying, 'Is he not a true fighting man who says that he is unable to forsake his rightful lord and lets him escape, saving his life? He is a man worthy to be one's com-

1 Lit., 'from the furthest point an arrow would reach from behind.'

2 Lit., 'qan.' Cf. above, $\$ 149$. 
panion.' And favouring him, he did not have him killed. 'Because Quyildar lost his life, ${ }^{1}$ Qadaq Ba'atur and one hundred Jirgin must serve Quyildar's wife and children. If boys are born to them, they must in turn serve Quyildar's descendants to the offspring of his offspring. If girls are born to them, their parents must not betroth them according to their own wishes, for their daughters must be servants and attend to Quyildar's wife and children.' He gave this order favouring Qadaq Ba'atur.

Because Quyildar Sečen had opened his mouth and spoken first, even before J̈̈̈rčede $i^{2}$, Činggis Qa'an favoured him with the following order: 'On account of Quyildar's service, Quyildar's descendants to the offspring of his offspring shall receive the bounty granted to orphans.'

${ }^{2}$ See above, $\$ 171$. 


\section{THE SECRET HISTORY OF THE MONGOLS}

\section{CHAPTER SEVEN}

186 Thus Činggis Qa'an crushed and despoiled the Kereyit people, distributing them on all sides. He gave Taqai Ba'atur of the Suldus one hundred Jirgin in reward for his services. Further, Činggis Qa'an ordered as follows: Ong Qan's younger brother J̌aqa Gambu had two daughters. The elder one, Ibaqa Beki, Činggis Qa'an took for himself. The younger one, Sorqaqtani Beki, he gave to Tolui. For that reason, saying that Jaqa Gambu and the personal subjects belonging to him should be kept together and be regarded like the second shaft of a cart for himself, he showed favour to $\breve{J a q a}$ Gambu and did not take his people away from him.

187 Čnggis Qa'an also gave the following order: 'Because of Badai's and Kišiliq's service, they shall have Ong Qan's golden tent just as it stands, with his golden bowls and vessels, together with the people who looked after them, and the Ongqojit Kereyit as their bodyguards. You, Badai and Kišiliq, enjoy the privilege of being freemen to the offspring of your offspring, allowed to carry quivers and drink the ceremonial wine!

When swiftly pursuing many foes,

If you get booty,

What you get you shall take away.

When in a battue

You slaughter wild beasts,

What you slaughter you shall take away.'

He further ordered: 'Because of the vital service performed by Badai and Kišiliq, and under the protection of Eternal Heaven, I crushed the Kereyit people and, indeed, gained the high throne. In future, the offspring of my offspring who will occupy this throne of mine must successively remember those two who performed such service!' So he ordered. 
When the Mongols subjugated the Kereyit people, they distributed them among each other so that nobody went short. They distributed the Tümen Tübe'en ${ }^{1}$ and they all took of them until they had plenty. They despoiled the Olon Dongqayit in less than a day. As for the brave Jirgin who used to strip the blood-stained clothing and possessions from the enemy, they divided and apportioned them, but could not give some to everybody. Having in this way annihilated the Kereyit people, Činggis Qa'an spent that winter at Abǰi'a Ködeger. ${ }^{2}$

188 Ong Qan and Senggüm escaped with their bare lives ${ }^{3}$ and went away, unwilling to submit to Činggis Qa'an. Ong Qan, who was suffering from thirst, was going to drink at Nekün Usun ${ }^{4}$ of Didik Saqal ${ }^{5}$ when he came across the Naiman patrolman Qori Sübeči. Qori Sübeči seized Ong Qan and although the latter declared, 'I am Ong Qan', Qori Sübeči did not recognise him and, disbelieving him, slew him on the spot.

Senggüm did not go to Nekün Usun of Didik Saqal, but bypassed it and entered the Čöl. ${ }^{6}$ While searching for water, he ${ }^{7}$ dismounted and stalked some wild asses that were standing there, plagued by gadflies. Senggüm's companion, the equerry Kököčü had his wife with him. With Senggüm they were altogether three of them. $\mathrm{He}^{8}$ gave his horse to his equerry Kököču to hold. The equerry Kököčü led the horse away and started trotting back home. His wife said,

'When you wore gold-embroidered clothes,

And ate tasty dishes,

$\mathrm{He}^{8}$ called you "my Kököčü." How can you go away now, forsaking and abandoning in this way your lord

1 = Tümen Tübegen. Cf. above, $\$ \S 170,171$.

2 I.e., 'Shrunk (?) Height (or Elevation).'

${ }^{3}$ Lit., 'with nothing other than their bodies.' Cf. the end of $\$ 109$ above.

4 I.e., 'Slave Water (= Spring?).'

5 I.e., 'Mud Beard.' For this odd name see RSH 2.675-76.

6 I.e., 'the Desert' (= the Gobi).

7 Lit., 'Senggüm.'

8 I.e., Senggüm. 
Senggüm?' So saying, his wife stopped there and remained behind.

Kököčü said, 'Surely you have said to yourself, "I want to take Senggüm as my man!" To these words his wife said, 'You call me "A woman with a dog's face;"1 all the same give him at least his golden cup - let him at least draw water and drink!' Thereupon the equerry Kököčü threw the golden cup back at him, saying, 'Take it!', and trotted off.

And so he came to $u s$, and upon his arrival the equerry Kököčü said to Činggis Qa'an, 'This is how I have come, leaving Senggüm in the Čöl', and he related from beginning to end everything that had been said between himself and his wife. Činggis Qa'an then ordered: 'To his wife I will show favour. As for the equerry Kököčü himself, who comes here having in this manner abandoned his rightful lord, who would now trust such a man and take him for a companion?' He cut him down and cast away his body.

189 Gürbesü, the mother of Tayang Qan of the Naiman, said, 'Ong Qan was the great old qan of former days. Bring his head here and if it is really his we shall sacrifice to it!' She sent a messenger to Qori Sübeči and had him cut off and bring back his ${ }^{2}$ head. She recognized it and placed it on a large white felt rug. She had her daughtersin-law perform the rites pertaining to a daughter-in-law, ordered that the ceremonial wine be drunk and the horse fiddle be played, and, holding the cup, made an offering to the head.

The head, being then so honoured, laughed. 'It laughed', said Tayang Qan; he stamped on it and crushed it to pieces. Thereupon Kökse'ü Sabraq said, 'You have cut off the dead qan's head and brought it here; the next thing you do is to crush it to pieces! This is not right. The sound of our dogs' barking has turned nasty. ${ }^{3}$ Inanča

\footnotetext{
${ }^{1}$ I.e., a shameless bitch - referring to an unfaithful wife.

2 I.e., Ong Qan's.

${ }^{3}$ I.e., of bad omen.
} 
Bilge Qan formerly said:

"My wife is young, but

I, her husband, have become old.

This son of mine Tayang

I begot only through magic.

$\mathrm{Ah}$, this son of mine, born a weakling,

Has grown weak and emaciated: ${ }^{1}$

Will he be able to care for and control

My numerous, base and unruly people?"

So he said. Now the dogs are barking and this barking sounds as if a calamity is approaching. The rule of our queen Gürbesü has become harsh, and you, my qan Torluq Tayang, are soft. You have no thought or skill except for falconry and hunting.'

Being told so, Tayang Qan then said, 'We hear that there are a few Mongols yonder in the east. These people with their quivers terrified the great old Ong Qan of former days, causing him to desert his own companions and perish. Do they now want to be rulers themselves? Even if there are two shining lights, the sun and the moon, in the sky above - both sun and moon are indeed there yet how can there be two rulers on earth? Let us go and bring here those few Mongols!'

At that, his mother Gürbesü said, 'What could we do with them? The Mongol people have always smelt bad and worn grimy clothes. They live apart, and far away. Let them stay there. But we might perhaps have their fine daughters and daughters-in-law brought here and, making them wash their hands, perhaps just let them milk our cows and sheep.'

On this Tayang Qan said, 'If that is so, what do they have for us to worry about? Let us go to those Mongols and we will surely bring back their quivers!'

190 To these words Kökse'ü Sabraq said, 'How boastfully you speak! O Torluq Qan, is this proper? You had better stop talking!' Despite Kökse'ü Sabraq's warning, Tayang Qan sent an envoy called Torbi Taš to Alaquš Digit Quri

${ }^{1}$ Doubtful interpretation; see RSH 2.682. 
of the Önggüt with this message: 'We are told that there are a few Mongols yonder east. You be the right wing. I shall join you from here and we will take the quivers of those few Mongols!'

Alaquš Digit Quri replied to these words saying, 'I cannot be the right wing.' Having sent this message, Alaquš Digit Quri had the following communication conveyed to Činggis Qa'an through his envoy called Yuqunan: 'Tayang Qan of the Naiman is coming to take your quivers. He approached me saying that I should be the right wing, but I refused. Now I am sending you this warning, for I fear that if he comes you may be robbed of your quivers.'

Just at that time Činggis Qa'an was hunting in the Teme'en Steppe; ${ }^{1}$ he was encircling Tülkin Če'üt ${ }^{2}$ when Yuqunan, the envoy sent by Alaquš Digit Quri, arrived to deliver this message.

On receiving this message, and whilst still at the hunt, they at once discussed what to do. Many of the men said, 'Our geldings are lean, there is nothing we can do now.' To that Otčigin Noyan retorted saying, 'How can one make the excuse that the geldings are lean? My geldings are fat! How can we stay put when we hear such words as these?' Then Belgütei Noyan spoke: 'If, when one is still alive, an enemy is allowed to take away one's quiver, what is the advantage of living? Isn't it right for any man born that when he dies he should lie with his quiver and bow alongside his bones? The Naiman people are boastful, bragging that they possess a great country and a large population. If now, grasping the chance their boasts afford $u s$, we set out on a campaign and remove their quivers, would this be so difficult? If we go forward, won't their numerous herds come to a halt and stay behind? Burdened with their palatial tents, won't they abandon them? Won't their many people depart and seek shelter in high places? How can we stay put and allow such people to keep boasting in this way? Let us ride

\footnotetext{
Lit., 'Camel Steppe (or Plain).'

2 I.e., 'Tülkin (?) Hills.'
} 
against them at once!' Thus he spoke.

191 Čnggis Qa'an approved these words of Belgütei Noyan and, returning from the hunt, moved from Abjiqa Köteger ${ }^{1}$ and set up camp at Keltegei Qada, at the Or Bend of the Qalqa River. ${ }^{2}$ He counted his troops and on the spot formed units of a thousand men, appointing the commanders of a thousand, the commanders of a hundred and the commanders of ten. Thereupon he appointed as chamberlains ${ }^{3}$ Dödei Čerbi, Doqolqu Čerbi, Ögele Čerbi, Tolun Čerbi, Bučaran Čerbi and Söyiketü Čerbi. Then, having appointed these six chamberlains, he formed units of a thousand, a hundred, and ten men, and he chose and recruited eighty men to serve on roster as nightguards and seventy men to serve as dayguards. He recruited them from the sons and younger brothers of commanders of a thousand and of a hundred, as well as from the sons and younger brothers of mere ordinary people, choosing and recruiting those who were able and of good appearance.

Showing favour to Arqai Qasar, he then ordered: 'Let him choose himself his brave warriors and form a unit of a thousand to fight before me in time of battle; in the many other days of peace they shall serve as my dayguards.' He also said, 'Ögöle Čerbi shall be the commander of the seventy dayguards, acting in consultation with Qudus Qalčan.'4

192 Činggis Qa'an further ordered: 'The quiverbearers, the dayguards, the stewards, the doorkeepers and the grooms are to go on roster duty in daytime. Before the sun sets they shall retire to make way for the nightguards; ${ }^{5}$ they shall go out to their geldings and spend the night there. At night, the nightguards shall see that those of their men whose duty it is to lie all around Our tent do so, and they shall put on roster those of their men whose

1 The Abji' a Ködeger of $\$ 187$ above.

2 See last note in $\$ 175$.

3 Čerbin. See note 2 in $\$ 120$ above.

4 I.e., sharing command with him. Ögöle = Ögele. See above, $\$ 120$, and RSH 2.693.

5 I.e., so as to be relieved by the nightguards. 
duty it is to stand at the door to guard it. The following morning, when We eat soup, the quiverbearers and the dayguards shall report to the nightguards; the quiverbearers, dayguards, stewards and doorkeepers shall all carry out their respective tasks and take their appointed places. When they have completed their days of service, consisting of a three-day and a three-night turn of duty, and have passed the three nights exactly in the same manner, ${ }^{1}$ they shall be relieved, but the night after their relief, they shall still be on duty as nightguards, and shall spend the night lying down all around.' So he ordered.

In this way Činggis Qa'an, having formed the units of a thousand, appointed the chamberlains, recruited eighty men to serve on roster as nightguards and seventy men to serve as dayguards; he let Arqai Qasar choose the brave men, ${ }^{2}$ and set out against the Naiman people from Keltegei Qada, at the Or Bend of the Qalqa River.

193 In the Year of the Rat, on the sixteenth day of the first month of summer (17 May 1204), the day of the Red Circle, ${ }^{3}$ he consecrated the standard ${ }^{4}$ and set forth. He rode upstream along the Kelüren River and sent Jebe and Qubilai ahead to reconnoitre. When they reached the Sa'ari Steppe, the Naiman patrol was already there, on the top of Mount Qangqarqan. Our patrolmen and theirs went in pursuit of one another. The Naiman patrol seized one of our patrolmen who had a white horse with a rather poor saddle. ${ }^{5}$ When the Naiman patrol caught that horse, they consulted among themselves and said, 'The Mongols' geldings are lean!'

When our soldiers reached the Sa'ari Steppe they halted there and discussed what to do. Then Dödei Čerbi gave the following advice to Činggis Qa'an: 'It is we who are few in number and, in addition to being few, we have arrived here exhausted. So, let us indeed halt and set up

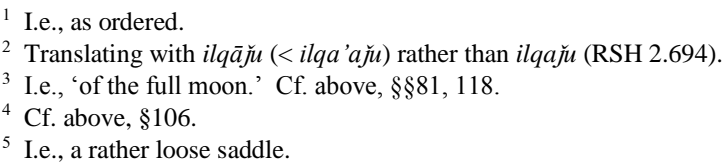


camp, spreading over the Sa'ari Steppe here until our geldings have eaten their fill. Let every single one ${ }^{1}$ of $u s$ each light fires in five different places and frighten the enemy with all these camp fires. They say the Naiman people are numerous, but they also say that their qan is a weakling who has not yet come out of his tent. While we keep them in doubt with the fires, our geldings will eat their fill. When our geldings are satiated, we shall chase the Naiman patrolmen and, pressing hard on them, we shall make them rejoin the main body of the army. If we engage them in combat in that confusion, won't we get the better of them?'

Approving these words of advice from Dödei Čerbi, Činggis Qa'an gave the following order: 'Things being so, let them light the fires!', and he proclaimed it as law to the soldiers. ${ }^{2}$ Thus, they set up camp spreading over the Sa'ari Steppe and everyone ${ }^{1}$ was made to light fires in five different places.

At night the Naiman patrolmen, seeing so many night-fires from the top of Mount Qangqarqan, said, 'Did we not say that the Mongols are only few in number? Their camp fires are more numerous than the stars!' They had sent to Tayang Qan the little white horse with the rather poor saddle; now they sent him this message: 'The Mongol troops have set up camp so as to cover the whole Sa'ari Steppe; they seem to increase daily, and their fires are more numerous than the stars.'

194 When this news from the patrolmen reached him, Tayang Qan was at Qačir Usun ${ }^{3}$ in the Qangqai Mountains. Upon receiving the news he sent word to his son Gücülük Qan: 'The geldings of the Mongols are lean, but our patrolmen say that their camp fires are more numerous than the stars. The Mongols are, therefore, many.

If we engage them and fight them to the end, Will it not be difficult to disengage ourselves?

${ }^{1}$ Lit., 'every living person', i.e. every individual in the camp without exception.

2 For translation here of jasaq as 'law', see RSH 2.697.

3 I.e., 'Mule Water.' 
If we engage them and fight them to the end,

They will not blink their black eyes.

Is it advisable for us

To fight these tough Mongols

Who do not flinch even if their cheeks are pierced

And their black blood gushes forth?

We are told that the geldings of the Mongols are lean. Let us move, withdrawing our people across the Altai. We shall then reorganize our troops and lure them ${ }^{1}$ after us as we go. We shall march until we reach the southern slopes of the Altai, fighting a dog's fight. ${ }^{2}$ Our geldings are fat: when we have made their bellies leaner and have exhausted the geldings of the Mongols we shall turn back and smash into their faces.' He sent this message.

To these words Güčülük Qan said, 'Again that woman Tayang! He speaks such words because he has lost courage. Where would this vast number of Mongols have come from? Most Mongols, together with J̌amuqa, are here with us. That woman Tayang,

Who dares not walk further than

A pregnant woman goes to urinate;

Who does not even venture so far as

A wheel-tied calf reaches for its feed,

has lost heart and has sent me that message, hasn't he?'

Gücülük Qan through the envoy had his words conveyed to his father to hurt and distress him; to these words, whereby Tayang Qan himself was spoken of as behaving like a woman, Tayang Qan said, 'May the strong and proud Güčülük not lose this pride of his on the day when we meet on the battlefield and slay one another! When we meet on the battlefield and fight to the end it will surely be difficult to disengage ourselves!'

Upon these words Qori Sübeči, a high official who held command under Tayang Qan, said, 'Your father Inanča Bilge Qan never showed a man's back or a gelding's rump to an enemy that was his match. Now you, how can you lose heart when it is still so early in the

\footnotetext{
1 I.e., the Mongols.

${ }^{2}$ I.e., engaging in skirmishes.
} 
morning? Had we known that you would have lost courage in this manner, shouldn't we have brought your mother Gürbesü, even though she is only a woman, and given her command of the army? What a pity, alas, that Kökse'ü Sabraq should have become so old! The discipline in our army has grown lax! This is, surely, the favourable time and the destiny of the Mongols decreed by Heaven and Earth. We are finished! Ah, weakling Tayang, it looks as if you are quite powerless.' Thus he spoke and, having struck on his quiver, he trotted off and went his separate way.

195 At this Tayang Qan grew angry and said, 'A life means to die, a body means to suffer: it is the same destiny for all! That being so, let us fight!' Moving from Qačir Usun he went downstream along the Tamir River and crossed the Orqon. Passing along the eastern fringe of the Naqu Cliff he reached Čakirma'ut, ${ }^{1}$ where Činggis Qa'an's patrolmen saw him as he was approaching. They sent a message to Činggis Qa'an saying, 'The Naiman have arrived and are drawing near.'

When this news reached him, Činggis Qa'an said, 'The more numerous, the greater damage; the less numerous, the lesser damage.' ${ }^{2}$ He rode against them and, having driven away their patrolmen, he arrayed his troops and together with the army leaders decided to advance in 'caragana' marching-order, to stand in 'lake' battle-formation and fight a 'chisel' combat. ${ }^{3}$

Having spoken thus, Činggis Qa'an in person formed the vanguard, putting Qasar in charge of the main body of the army and Otčigin Noyan in charge of the reserve horses. The Naiman withdrew from Čakirma'ut and took up position south of Naqu Cliff, along the mountain fringes. Then our patrolmen arrived driving away the Naiman patrolmen and pursuing them until they joined the main body of their army south of Naqu Cliff.

\footnotetext{
1 I.e., 'Three-Year-Old Deer (?).'

${ }^{2}$ A popular saying, used here with reference to Tayang Qan's more numerous forces.

${ }^{3}$ For these military tactics see RSH 2.704-05.
} 
Tayang Qan saw them arriving thus in hot pursuit. At that time Jamuqa had also set forth with his troops and had come with the Naiman. As he was there, Tayang Qan asked J̌amuqa, 'What sort of people are those, who are like wolves that come chasing a flock of sheep and pursuing them as far as the sheep-pen? What people are these, drawing near in such hot pursuit?'

J̌amuqa said, 'My sworn friend Temüjin has been feeding "four hounds" on human flesh, leashing ${ }^{1}$ them with iron chains. They are the ones approaching in pursuit of our patrol. Those "four hounds",

Their foreheads are of hardened copper,

They have chisels for snouts,

And awls for tongues;

With hearts of iron,

And swords for whips,

They advance feeding on dew

And riding on the wind.

On the day of killing

They eat human flesh, those ones;

On the day of battles

They make human flesh

Their provisions, ${ }^{2}$ those ones.

Loosed from their iron chains - which had surely restrained them! - they are now full of joy and are approaching thus, slavering at the mouth', he said. 'Who are those "four hounds"? They are Jebe and Qubilai, Jelme and Sübe'etei. Those are the four.'

Tayang Qan said, 'Let us then stay away from those vile creatures!' He retreated in haste and took up position astride the mountain.

When he saw them approaching from the rear and encircling them, ${ }^{3}$ leaping in delight, Tayang Qan again asked Jamuqa, 'What sort of people are these, who are like foals let loose early in the morning - foals that after sucking their mother's milk are always gambolling

1 Lit., 'binding.'

${ }^{2}$ I.e., as provisions for the road.

${ }^{3}$ I.e., Tayang Qan and J̌amuqa. 
around her? ${ }^{1}$ Why are they approaching, encircling us in this manner?'

Jamuqa said, 'These are called the Uru'ut and the Mangqut:

They rush after men armed with spears

And strip them of their blood-stained clothing;

Chasing after men armed with swords,

They fell and kill them,

And take away their valuables and clothing.

Do they not rejoice now as they draw near, bounding thus in delight?'

Thereupon Tayang Qan said, 'If that is so, let us stay away from those vile creatures!' He took up position, retreating further up the mountain.

Tayang Qan again asked J̌amuqa, 'Who is the one approaching from the rear, coming forward at the head of the army and drawing near like a greedy, slavering falcon?'

Jamuqa said, 'The one approaching us is my sworn friend Temüjuin. Over his whole body,

There is not a single chink

Where a hard copper awl can drive in its spike;

Nor a single chink

Where a wrought-iron sewing needle

Can insert its sharp point.

My sworn friend Temüjin is indeed drawing near, slavering thus like a greedy falcon. Have you seen him? You Naiman friends used to say that if you saw the Mongols, you would not leave them even the skin of a kid's hoof. Behold them now!'

On these words Tayang Qan said, 'This is simply dreadful! Let us take position further up the mountain!' They climbed up the mountain and took position.

Again Tayang Qan asked Jamuqa, 'And who is the one that is approaching from the rear as if in a compact mass?' Jamuqa said, 'Mother Hö'elün has raised one of her sons on human flesh: 
His body is three fathoms high,

And he dines on three-year old cattle;

Wearing a three-layered armour,

He is pulled along in his cart by three bulls.

When he swallows a man complete with quiver,

It does not get stuck in his throat.

When he gulps down a whole man,

It does not fill his stomach.

When he is angry and draws his bow,

And releases a forked-tip arrow,

He shoots and pierces ten or twenty men

Who are beyond a mountain;

When he draws his bow and releases

A long-range thin arrow,

He shoots and pierces through his enemies,

The ones he fights

Who are beyond the steppe.

When he shoots, drawing his bow to the full,

He covers nine hundred fathoms;

When he shoots, drawing it only a little,

He covers five hundred fathoms.

Different from all other men,

He was born a coiling dragon-snake.

His name is J̌či Qasar.

That is he!' Tayang Qan then said, 'If this is so, let us strive for the mountain heights and go further up!' They climbed further up the mountain and took position.

Again Tayang Qan asked Jamuqa, 'Who is approaching after him?' Jamuqa said, 'He is the youngest son of Mother Hö'elün. He is called Otčigin, the Easy-going. $\mathrm{He}$ is an early sleeper and a late riser, yet

He does not lag behind, when the army is in full array;

He does not lag behind, when the army is in position.'

Tayang Qan said, 'If this is so, let us go up to the top of the mountain!'

196 After speaking such words to Tayang Qan, J̌amuqa separated from the Naiman and went off on his own. He sent an envoy to deliver a verbal message to Činggis Qa'an saying, 'Tell this to the sworn friend', and he said: 
'At my words Tayang Qan has lost his head And in panic he has scrambled to the heights.

Frightened to death by the words from my mouth He has climbed up the mountain.

Sworn friend, take care!

Up they went, climbing the mountain,

And have lost the will to resist.

As for me, I have separated from the Naiman.' He sent this message.

Late in the day Čnggis Qa'an surrounded the mountain of Naqu Cliff; he took up position with his troops and spent the night there.

That night the Naiman moved from their position and tried to escape. Tumbling down from the height of Naqu Cliff, they piled on top of each other; they fell breaking their bones and died crushing each other till they were like heaps of rotten logs.

The following morning Činggis Qa'an finished off Tayang Qan. Güčülük, who had been staying apart from the rest moved from there with a few men, abandoning his own companions. When the Mongol troops caught up with him, he set up a circular camp at the Tamir River, but unable to hold that camp he again set out and fled further away.

Činggis Qa'an utterly defeated and conquered the people of the Naiman tribe on the southern slopes of the Altai. The J̌adaran, Qatagin, Salǰi'ut, Dörben, Tayiči'ut, Onggirat and other people who had been with Jamuqa also submitted on that occasion.

Činggis Qa'an had Tayang's mother Gürbesü brought to him and said to her, 'You used to say that the Mongols have a bad smell, didn't you? Why, then, did you come now?' And Činggis Qa'an took her as wife.

197 In that same Year of the Rat (1204), in the autumn, Činggis Qa'an fought with Toqto'a Beki of the Merkit at the Qaradal Source. He dislodged him from there and subdued his tribe and all his people in the Sa'ari Steppe. 
Toqto'a, with his sons Qudu ${ }^{1}$ and Čila'un and a few people, dispossessed of all but their bodies, ${ }^{2}$ got away by flight.

When the Merkit people were thus being subdued, Dayir Usun of the Qo'as Merkit ${ }^{3}$ took his daughter Qulan Qatun with him and came to offer her to Činggis Qa'an. On the way he was hindered by some soldiers and met Naya'a Noyan of the Ba'arin. Dayir Usun said to him, 'I am on my way to offer this daughter of mine to Činggis Qa'an.' Detaining him, Naya'a Noyan then said, 'Let us go together to offer your daughter.' As he detained him, he said, 'In this time of disorder, if you go alone, soldiers on the way will certainly not leave even you alive, and your daughter too will be in much trouble.' And he held Dayir Usun for three days and three nights.

After that Naya'a Noyan took Qulan Qatun and Dayir Usun, and brought them together to Činggis Qa'an. Činggis Qa'an then said, 'Naya'a, why did you detain her?' He got very angry and, ordering that Naya'a be rigorously and minutely questioned, made this case a matter of law. ${ }^{4}$

While they were questioning him, Qulan Qatun said, 'Naya'a said to my father, "I am a high officer of Činggis Qa'an. Let us go together to offer your daughter to the Qa'an. The soldiers on the way will be troublesome." So he warned us against going alone. Now, had we met with other troops but Naya'a's, no doubt we would have been intercepted and would have got into difficulties. Perhaps our chance meeting with this Naya'a was good for us. Now that Naya'a is being questioned, the Qa'an may condescend to inspect my body, which my father and mother bore by Heaven's will.' She had this message conveyed to Činggis Qa'an.

When Naya'a was questioned he said, 'I have no

\footnotetext{
${ }^{1}$ Cf. above, $\$ 177$.

${ }^{2}$ Cf. above, $\$ 109$.

3 A mistake for U'as Merkit.

${ }^{4}$ I.e., made a law to deal with such matters in the future.
} 
other face than that known to the Qa'an: ${ }^{1}$

If I come across maidens and ladies

Of foreign people with beautiful cheeks,

And geldings with fine croups,

I always say, "They are the Qa'an's!"

If ever I think differently from this, let me die!'

Činggis Qa'an approved of Qulan Qatun's testimony; then, that very day, he examined her accordingly and it turned out to be just as Qulan Qatun had stated.

Činggis Qa'an showed favour to Qulan Qatun and loved her. As Naya'a's words had been confirmed, he approved of him. He showed favour to him too, saying, 'He is a truthful man, I shall entrust him with an important task!'

${ }^{1}$ I.e., 'I am sincere and loyal to the Qa'an.' 


\section{THE SECRET HISTORY OF THE MONGOLS}

\section{CHAPTER EIGHT}

After Činggis Qa'an subjugated the Merkit people, of the two wives of Toqto'a Beki's eldest son Qudu - Tögei and Döregene - he gave Döregene to Ögödei Qa'an.

Half of the Merkit people revolted and barricaded themselves in the Taiqal stronghold. Činggis Qa'an then gave orders that Čimbai, the son of Sorqan Šira, be put in command and sent him to attack the entrenched Merkit with the troops of the left ${ }^{1}$ wing.

Unwilling to submit, Toqto'a with his sons Qudu and Čila'un - only a few men altogether - had escaped with their bare lives. Činggis Qa'an pursued them and spent the winter south of the Altai.

In the spring of the Year of the Ox (1205), he set out and crossed the Alai. ${ }^{2}$ Güčülük Qan of the Naiman, after his people had been captured by Činggis Qa'an, would not submit and with his companions - a few men in number - went and made an alliance with Toqto'a of the Merkit. They came together at the Buqdurma source of the Erdis ${ }^{3}$ River and arrayed their troops.

When Činggis Qa'an arrived they fought. Toqto'a was struck there and then by a 'random' arrow and fell. His sons could not bury him, nor could they take his body away, so they severed his head and took that away with them. Then the Naiman and the Merkit were unable, even with their united forces, to keep up the fight and fled. When they moved away and crossed the Erdiš, most of them fell into the river and drowned. The few Naiman and Merkit that got through separated and went in different directions after completing the crossing of the

${ }^{1}$ Read 'right' (= 'west'); the text has 'left'. See RSH 2.730.

2 Arai in the text. See RSH 2.730.

$3=$ Erdiš. Cf. below and $\S \S 207,264$. 
Erdis. ${ }^{1}$ Güčülük Qan of the Naiman went off and, passing through the country of the Ui'ur ${ }^{2}$ and the Qarlu'ut, joined the gür qan of the Qara Kidat who was at the Čui River in the country of the Sarta'ul. The Merkit, led by Qudu, $\mathrm{Qal}^{3}$ and Čila'un, the sons of Toqto'a of the Merkit, went off and crossed the country of the Qanglin and the Kimča'ut.

After that, Čnggis Qa'an turned back, crossed the $\mathrm{Alai}^{4}$ and settled in his base camp. Čimbai utterly defeated the Merkit entrenched in the Taiqal stronghold. Then, with regard to these Merkit, Činggis Qa'an ordered that those to be killed were to be killed and the remainder were to be despoiled by the soldiers.

The Merkit who had submitted earlier rose again in rebellion and tried to break out from the base camp, but our servants in the camp brought them under control. Činggis Qa' an then spoke, saying, 'I had said that they be kept together as one tribe, but these same people have now revolted', and he had the Merkit distributed here and there $^{5}$ down to the last one.

199 In that same Year of the Ox (1205) Činggis Qa'an ordered Sübe'etei, who had been provided with an iron cart, to pursue the sons of Toqto'a headed by Qudu, Qal and Čila'un. When he sent him on his mission, Činggis Qa'an had the following verbal message conveyed to Sübe'etei ${ }^{6}$ : 'The sons of Toqto'a having at their head Qudu, Qal and Čila'un left in fright and haste, then turned back, exchanged shots with us and went off like lassoed wild asses or stags with arrows in their bodies. If they grow wings and fly up into the sky, you, Sübe'etei, will you not fly up like a gerfalcon and catch them? If they turn into marmots and burrow into the ground with their

$1=$ Erdiš. Cf. above and $\$ \S 207,264$.

${ }^{2}$ Ui' urtai in the text. See RSH 2.733.

${ }^{3}$ Qat in the text, but Qal in $§ 199$, a reading comfirmed elsewhere (RSH 2.733).

4 Arai in the text.

5 I.e., among other groups.

${ }^{6}$ Written Sübētei. 
claws, will you not become an iron rod and, digging and searching for them, catch up with them? If they turn into fishes and plunge into the Tenggis Sea, ${ }^{1}$ you, Sübe'etei, will you not become a casting-net and a dragnet, and get them by scooping them out? And again, I send you to cross high mountain passes, to ford wide rivers; mindful of the long distance you have to cover, you must spare the army mounts before they become too lean and you must save your provisions before they come to an end. If a gelding is already completely exhausted it will be of no use to spare it then; if your provisions have already completely run out, how can you save them then? There will be many wild animals on your way: when you go, thinking ahead, do not allow your soldiers to gallop after and hunt down wild animals, nor let them make circular battues without limit. If you make a battue in order to give additional provisions to your troops, hunt with moderation. Except on limited battues, do not allow the soldiers to fix the crupper to the saddle and put on the bridle, but let the horses go with their mouths free. ${ }^{2}$ If they so discipline themselves, the soldiers will not be able to gallop on the way. Thus, making this a matter of law, whoever then transgresses $\mathrm{it}^{3}$ shall be seized and beaten. Send to Us those who transgress Our order if it looks that they are personally known to Us; as for the many who are not known to Us, just cut them down on the spot.

Beyond the rivers

You will perhaps lose courage,

But continue to advance

In the same way;

Beyond the mountains

You will perhaps lose heart,

But think of nothing else apart from your mission.

If Eternal Heaven grants you further strength and power, and you capture Toqto'a's sons, there is no need for you

1 Here metaphorically = 'the Ocean' (RSH 2.737).

2 Lit., 'removing the bit from the mouth', so that it hung free.

3 Lit., 'the law' (jasaq). 
to bring them back: cast them away there and then! ${ }^{1}$ So he ordered.

Činggis Qa'an said further to Sübe'etei: 'I send you on this expedition because, when I was small, I was frightened by the Uduyit of the Three Merkit circling three times around Burqan Qaldun. ${ }^{2}$ Mortal enemies like these, now gone again, swearing oaths against me, you shall reach, were you to go

To the furthest limit,

To the bottom of the deep!'

And so, in the Year of the Ox, he had an iron cart made to pursue them to the very end and sent Sübe'etei on his war mission with these final instructions: 'If you constantly think that even though We are out of sight it is as if We were visible, and even though We are far it is as if We were near, you will also be protected by Heaven Above!'

200 When Čnggis Qa'an annihilated the Naiman and the Merkit, Jamuqa was with the Naiman and his people were taken from him on that occasion. With only five companions he became an outcast. He went up the Tanglu Mountains, killed a wild sheep and roasted it. When it was time to eat it, Jamuqa there and then said to his companions, 'Whose sons, ${ }^{3}$ having today killed a wild sheep, are eating it like this?' While they were eating the meat of that wild sheep, his five companions laid hands on J̌amuqa and, seizing him, brought him to Činggis Qa'an.

When Jamuqa was brought here by his companions, he told someone to say to his sworn friend the Qa'an:

'Black crows have gone so far

As to catch a mandarin duck, ${ }^{4}$

Black skins ${ }^{5}$ and slaves have gone so far

1 I.e., 'execute them on the spot.'

2 See above, $\$ 103$.

3 I.e., 'What (sort of) persons?'

4 For this simile, which is illustrated in the following two lines, and paralleled just below, see RSH 2.743-44.

5 I.e., lowly or common tribesmen. 
As to raise their hands against their lord.

Qa'an, my sworn friend,

How can you be mistaken?

Grey buzzards have gone so far

As to catch a wild duck,

Slaves and servants have gone so far

As to seize their own master,

Surrounding him and conspiring against him.

Wise sworn friend of mine,

How can you be mistaken?'

To these words of Jamuqa, Činggis Qa'an said, 'How could we let men live who have raised their hands against their rightful lord? To whom can such men be companions? Cut down to the offspring of their offspring these people who have raised their hands against their rightful lord!' So he ordered, and had the people who had laid hands on Jamuqa cut down in his ${ }^{1}$ very presence.

Činggis Qa'an then said, 'Tell Jamuqa: "Now the two of us are united. Let us be companions! If we become each of us like one of the two shafts of a cart, would you think of separating yourself from me and being on your own? Now that we are together once more,

Let us each remind the other of what he has forgotten,

Let us each wake up the other who has fallen asleep.

Although you separated from me

And went a different way,

You remain my lucky, blessed sworn friend.

On the day one kills and is killed, surely

Your heart was aching for me.

Although you separated from me

And went a different way,

On the day one fights one another,

Your lungs and heart were aching for me.

When was that? When I fought the Kereyit people at the Qalaqalyit Sands you informed me of what you had said to 
Father Ong Qan. ${ }^{1}$ That was a service you did me. Then, the fact that you sent me a message with the news that you had frightened the Naiman people

Slaying them with your words,

Killing them with your mouth,

and said to me that I could regard them as $\mathrm{such}^{2}$ - that was another service you did me."

201 After Činggis Qa'an had spoken, J̌amuqa said, 'In early days when we were small, in the Qorqonaq Valley I agreed with my sworn friend the Qan to become sworn friends:

Together we ate food that is not to be digested,

To each other we spoke words that are not to be forgotten,

Together we were under our blanket

Sharing it between us, but

Stirred up by someone

Coming between us,

Pricked by someone

Standing at the side, ${ }^{3}$

We parted for good.

Saying to myself that

We had exchanged weighty words,

The skin of my black face

Peeled off in shame;

And so I have been living

Unable to come near you,

Unable to see the friendly face

Of my sworn friend the Qan.

Saying to myself that

We had exchanged unforgettable words,

The skin of my red face

Came off in shame;

And so I have been living

Unable to see the true face

Of my sworn friend with a long memory.

1 See above, $\$ 170$.

2 I.e., as frightened to death by the Mongols. See above, $\$ 196$.

3 Cf. above, $\S \S 127$ and 177. 
'Now my sworn friend the Qan shows favour to me and says, "Let us be companions!" But when it was the time for being companions, I was not one. ${ }^{1}$ Now, sworn friend,

You have pacified all our people,

You have unified all other peoples,

and the qan's throne has been assigned to you. Now that the world is at your disposal, of what use would I be as a companion to you? On the contrary, $O$ my sworn friend,

I would intrude into your dreams in the dark night,

I would trouble your heart in the bright day,

I would be a louse in your collar,

I would be a thorn in the inner lapel of your coat. ${ }^{2}$

'I had many paternal grandmothers. When I became disloyal to my sworn friend I made a mistake. Now, in this life - that of the sworn friend and me - my fame has indeed passed from sunrise to sunset. You, sworn friend, had a wise mother. You were born a hero, and as you had younger brothers, valiant companions and seventy-three geldings, ${ }^{3}$ you, my sworn friend, excelled me. As for me, I lost my parents when I was small and had no younger brothers. My wife is a prattler, my companions untrustworthy. Because of this I was excelled by my sworn friend, whose destiny was ordained by Heaven. If you ${ }^{4}$ want to show favour to me, let me die swiftly and your ${ }^{5}$ heart will be at rest. And if you ${ }^{4}$ condescend to have me put to death, let them kill me without shedding blood. When I lie dead, my bones buried in a high place, for ever and ever I shall protect you and be a blessing to the offspring of your offspring.

'In origin I am of a different birth, and so I was conquered by the august spirit of my sworn friend who is of higher birth. Do not forget the words that I have just

Lit., 'a companion to him.'

2 In short, 'I would be a constant nuisance to you.'

3 There is no mention of these geldings elsewhere in the SH.

${ }^{4}$ Lit., 'the sworn friend.'

${ }^{5}$ Lit., 'the sworn friend's.' 
spoken; think of them evening and morning and repeat them among yourselves. Now do away with me quickly!'

To these words of his Činggis Qa'an said, 'Although my sworn friend has parted from me and has been railing against Us, I have not heard that he has plotted harm against my life. He is a man who should learn from experience, but is not willing to. However, to kill him is not in accordance with the omens; to harm his life without good reason is not right. He is a man of high standing. Perhaps you should give him this reason: "Once, when Čoji Darmala ${ }^{1}$ and Taičar stole from each other their herds of horses, you, sworn friend J̌amuqa, wickedly stirred up rebellion against me. We fought at Dalan Baljut and you forced me to take refuge in the Jerene Gorge. You frightened me then, did you not? Now, when I say, 'Let us be companions!', you refuse; when I offered to spare your life, you declined." Tell him that. Say to him: "Now, according to your request, you shall die without your blood being shed."”

He ordered that Jamuqa be put to death without his blood being shed and that his body ${ }^{2}$ should not be abandoned in the open, but be given a fitting burial. He had Jamuqa executed there and then, and had his body buried as arranged.

202 And so, when the people of the felt-walled tents had been brought to allegiance, in the Year of the Tiger (1206) they all gathered at the source of the Onan River. They hoisted the white standard with nine tails and there they gave Činggis Qa'an the title of qan. Then they also gave the title of gui ong $^{3}$ to Muqali. On that occasion too, Jebe was sent on a war mission to pursue and seize Gücülük Qan of the Naiman. Having thus completed the task of setting the Mongol people in order, Činggis Qa'an said, 'To those who sided with me when I was establishing our nation, I shall express my appreciation

${ }^{1}$ Called J̌oči Darmala in $§ 128$ above.

2 Lit., 'bones.'

${ }^{3}$ I.e., 'Prince of State.' For this title, see RSH 2.761, 783. 
and, having formed units of a thousand, I shall appoint them commanders of a thousand.' So he decreed, and he appointed the following with the rank of commanders of a thousand: (1) Father Mönglik, (2) Bo'orču, (3) Muqali Gui Ong, (4) Qorči, (5) Ilügei, (6) Jü̈ř̌edei, (7) Qunan, (8) Qubilai, (9) J̌elme, (10) Tüge, (11) Degei, (12) Tolon, (13) Önggür, (14) Čülgetei, (15) Boroqul, (16) Šigi Qutuqu, (17) Güčü, (18) Kököčü, (19) Qorqosun, (20) Hüsün, (21) Quyildar, (22) Šiluqai, (23) J̌etei, (24) Taqai, (25) Čaqa'an Qo'a, (26) Alaq, (27) Sorqan Šira, (28) Buluqan, (29) Qaračar, (30) Kökö Čos, (31) Süyiketü, (32) Naya'a, (33) J̌ungšoi, (34) Güčügür, (35) Bala, (36) Oronartai, (37) Dayir, (38) Müge, (39) Buǰir, (40) Mönggü'ür, (41) Dolo'adai, (42) Bögen, (43) Qudus, (44) Maral, (45) J̌ebke, (46) Yuruqan, (47) Kökö, (48) J̌ebe, (49) Udutai, (50) Bala Čerbi, (51) Kete, (52) Sübe'etei, (53) Möngkö Qalǰa, (54) Qurčaqus, (55) Geügi (56) Badai, (57) Kišiliq, (58) Ketei (59) Ča'urqai, (60) Onggiran, (61) Toqon Temür, (62) Megetü, (63) Qada'an, (64) Moroqa, (65) Dori Buqa, (66) Iduqadai, (67) Širaqul, (68) Da'un, (69) Tamači, (70) Qa'uran, (71) Alči, (72) Tobsaqa, (73) Tungquidai, (74) Tobuqa, (75) Aǰinai, ${ }^{1}$ (76) Tüyideger, (77) Seče’ür, (78) J̌eder, (79) Olar Güregen, (80) Kinggiyadai, (81) Buqa Güregen, (82) Quril, (83) Ašiq Güregen, (84) Qadai Güregen, (85) Čigü Güregen, $(86,87,88)$ Alči Güregen leading the three Onggirat thousands, $(89,90)$ Butu Güregen leading the two Ikires thousands, (91, 92, 93, 94, 95) Alaquš Digit Quri Güregen of the Önggüt leading the five Önggüt thousands. Excluding the People of the Forest, ${ }^{2}$ the commanders of a thousand of the Mongol people appointed by Činggis Qa'an were ninety-five.

203 'Those ninety-five commanders of a thousand whom I have nominated, together with the sons-in-law', further said Činggis Qa'an, 'have been entrusted with units of a thousand and' - Činggis Qa'an declared - 'I shall now reward those among them who are most deserving.' And

\footnotetext{
1 Read Ačinai.

${ }^{2}$ I.e., the forest tribes of the north and north-west. See RSH 2.787.
} 
he said that the commanders having at their head Bo'orču and Muqali should come. At that time Šigi Qutuqu was inside the tent. When Čnggis Qa'an told him, 'Go and summon them!', Šigi Qutuqu said, 'Have Bo'orču and Muqali been of greater assistance than others? Have they given better service than others? If you want to give rewards, surely I was not less useful, surely I did not give lesser service?

From the time I was in the cradle And grew up at your noble threshold, Until this beard sprouted on my chin, I did not think of anyone else but you.

From the time I had a piss-pot at my crotch And, being at your royal threshold, I grew up Until this beard sprouted at my mouth, I did not make a single false step.

She ${ }^{1}$ let me lie at her feet

And brought me up as her own son;

She let me lie at her side

And brought me up as the younger brother of her children.

Now, what kind of reward will you give me?'

To these words of Šigi Qutuqu, Činggis Qa'an said, 'Are you not my sixth younger brother? To you, my lateborn younger brother, the reward: you shall be allotted the same share as the younger brothers; furthermore, on account of your services, you shall not be punished for up to nine crimes.' So he ordered.

And he said, 'When, protected by Eternal Heaven, I am engaged in bringing the entire people under my sway, be

Eyes for me to see with,

Ears for me to hear with. ${ }^{3}$

Divide up all the subject people and apportion them to Our mother, to Us, to Our younger brothers and sons ac-

1 I.e., Mother Hö'elün.

2 See above, $\$ 135$.

3 Cf. above, $\$ 138$. 
according to the name of the people, ${ }^{1}$

Splitting up those that live in felt-walled tents,

Separating those that live in dwellings with wooden doors.

Let no one disobey your word!'

Further, he entrusted Šigi Qutuqu with the power of judgement over all and said to him, 'Of the entire people,

Curbing theft,

Discouraging falsehood,

execute those who deserve death, punish those who deserve punishment. Furthermore, writing in a bluescript register all decisions about the distribution and about the judicial matters of the entire population, make it into a book. ${ }^{2}$ Until the offspring of $m y$ offspring, let no one alter any of the blue writing that Šigi Qutuqu, after deciding in accordance with me, shall make into a book with white paper. Anyone who alters it shall be guilty and liable to punishment.'

Šigi Qutuqu said, 'How can a late-born younger brother like me take the same and equal share as that of the others? If the Qa'an wants to reward me, let him decide in favour of granting me the people from the towns that have walls of pounded earth.' So he requested, and to these words of his Cinggis Qa'an said, 'You yourself have determined your own part; you decide!'

After he had made Činggis Qa'an favour him thus, Šigi Qutuqu went out and, calling the leaders with Bo'orču and Muqali at their head, let them into the tent.

204 Činggis Qa'an then addressed Father Mönglik and said: 'You fortunate and blessed man,

Who at birth were born together with me,

When growing, grew up together with $m e,{ }^{3}$

how many times have you helped and protected me? Among those was the occasion when Father Ong Qan and sworn friend Senggüm deceitfully invited me to the

${ }^{1}$ I.e., according to their importance and lifestyle (nomadic or settled populations).

2 I.e., into a permanent record.

${ }^{3}$ Cf. below, $\$ 211$. 
betrothal feast and on the way I spent the night in Father Mönglik's tent. ${ }^{1}$ Had you, Father Mönglik, not dissuaded me then, I would have gone right

Into whirling waters,

Into a blazing fire.

Recalling only that service of yours, how could anybody forget it until the offspring of their offspring? Recalling that service, I will henceforth let you occupy the seat at the very beginning of this side in my tent. Yearly and monthly I shall consult with you, ${ }^{2}$ and I shall give you gifts and favours. I shall be attending on you, until the offspring of your offspring!' So he declared.

205 Further Činggis Qa'an spoke to Bo'orču: 'When I was small I was robbed of eight horses, the light-bay geldings. ${ }^{3}$ I spent three days and nights on the way pursuing them and, as I was going, we met each other. Then you said to me, "You came because you are in difficulties; I will join you as a companion!" and, without a word even to your father in the tent, you who were then milking a mare, concealed your leather bucket and pail in the grass. You made me leave my short-haired chestnut horse and set me on a white horse with a black back, and you yourself rode a fast dun mare. You left your herd of horses without a master and in haste became my companion in the steppe. Again we spent three days and nights in pursuit before we reached the circular camp with the stolen light-bay geldings. They were standing at the edge of the camp. We stole them, drove them away and brought them back, the two of us. Your father was Naqu Bayan. You, his only son, what did you know about me when you became my companion? You became my companion because of your brave heart. Afterwards I kept on thinking about you and when I sent you Belgütei to ask you to join me again as a companion,

You jumped on your chestnut horse with the arched back,

1 See above, $\$ 168$.

2 I.e., to seek advice.

3 See above, $§ \S 90-93$. 
You tucked your grey woollen cloak behind you, and came to join me. ${ }^{1}$ And when

The Three Merkit came against us and

Thrice circled Burqan Qaldun,

That mountain you circled with me. ${ }^{2}$

And when, after that, we passed the night at Dalan Nemürges with our troops pitched opposite those of the Tatar people, the rain poured down incessantly day and night. Saying that I ought to get my night's rest, you covered me with your felt cloak so that the rain would not fall upon me and throughout the night you stood beside me shifting one of your feet only once. This was indeed a sign of your bravery. Other than that, what brave deeds of yours am I to mention? You two, Bo'orču and Muqali,

You urged me to carry out what was right,

You persuaded me not to do what was wrong,

and in this way made me gain this throne. Now you shall sit higher than all the others and shall not be punished for up to nine crimes. Bo'orču will be in charge of the ten thousand men of the right wing which extends westwards up to the Altai Mountains. ${ }^{3}$ So he ordered.

206 Further, Činggis Qa'an said to Muqali, 'When we set up camp near the Leafy Tree in the Qorqonaq Valley around which Qutula Qan used to dance, ${ }^{4}$ because the words that a heavenly sign foretold to Muqali were a clear portent, I there and then, thinking of his father Gü'ün Qo'a, ${ }^{5}$ pledged my word to Muqali. Accordingly, he shall henceforth sit upon a seat [above all others] and shall be gui ong ${ }^{6}$ of all the people, and so it shall be until the offspring of Muqali's offspring.' He gave him the title of gui ong and ordered: 'Let Muqali Gui Ong be in charge of the

1 See above, $\$ 95$.

2 See above, $\$ 103$.

3 Lit. 'using the Altai as a pillow'. See RSH 2.781.

4 See above, $\$ \S 57$ and 117.

5 The Gü'ün U'a of $\$ 137$ above.

${ }^{6}$ For this title, see the first note to $\$ 202$ above. 
ten thousand men of the left wing which extends eastwards up to the Qara'un Jidun Mountains.'

207 Činggis Qa'an said to Qorči, 'You once made a prophecy about me and, from the time I was small until now, for a long time

When it was wet,

You suffered the wet with me;

When it was cold,

You suffered the cold with me.

Indeed, you have constantly been a beneficent spirit ${ }^{2}$ to me. At that time you, Qorči, said, "If the prophecy comes true and if it is fulfilled by Heaven according to your wishes, let me have thirty women." Now, because it has come true, I shall favour you. Look at the fine women and fine girls of the people who have submitted to us and choose thirty women from among them.' So he ordered.

Further, he ordered: 'On top of the three thousand Ba'arin that he already leads, Qorči, together with Taqai and Ašiq, shall add to the number so as to make up a full ten thousand with the Činōs of the Adarkin, the Tö'ölös and the Telengüt, and Qorči shall be their commander. Freely establishing his camp along the Erdiš River up to the People of the Forest, Qorči shall reduce the People of the Forest to submission and be in charge of the ten thousand.' And he ordered: 'The People of the Forest must not act this way or that without Qorči's agreement. Those who act without his agreement, he should not hesitate to kill them.'

208 Further, Činggis Qa'an said to Jürčedei, 'Your most important service was at the time when we were fighting with the Kereyit at the Qalaqalyit Sands and were worrying about the outcome of the battle. Sworn friend Quyildar then made an oath but you, Jürčedei, carried out his task. In carrying it out you, Jürčedei, attacked and overcame the Jirgin, the Tübegen, the Dongqayit, Quri

1 Lit. 'using the Qara'un J̌idun as a pillow'; see the note just above.

${ }^{2}$ Nendü qutuq. For this expression, see RSH 2.784. For Qorči's prophecy, see above $\S 121$. 
Šilemün ${ }^{1}$ and his thousand bodyguards, the best troops all of them - and, reaching the main body of their army, you shot an učumaq arrow into one of Senggüm's bright red cheeks. ${ }^{2}$ Because of this, "the door was opened and the reins were loosened" for me by Eternal Heaven. ${ }^{3}$ Had Senggüm not been wounded, what would have become of us? That was indeed Jürčedei's greatest and most important service.

'When he separated from me, moving along the river Qalqa downstream, I constantly thought of Jürčedei as if he were the shelter afforded by a high mountain. He then went off ${ }^{4}$ and we arrived at Lake Baljuna to water our animals. When we set out again from Lake Baljuna, Jürčedei went ahead to reconnoitre. We took the field against the Kereyit and, with our strength increased by Heaven and Earth, we utterly defeated and subdued the Kereyit people. ${ }^{5}$ The most important people ${ }^{6}$ being cut off, the Naiman and the Merkit lost heart; they could no longer fight and were scattered.

'In the struggle in which the Merkit and the Naiman scattered, Jaqa Gambu of the Kereyit was allowed, by reason of his two daughters, to stay with his own subject people as a whole group. But when, for the second time, he became hostile and separated from us, Jüurčedei lured him with a stratagem and, after seizing him, made an end of Jaqa Gambu who had broken with us for good. For the second time we exterminated and plundered the people of that J̌aqa Gambu. This was surely Jürčedei's second service.'

Because, on the day one kills and is killed,

He disregarded ${ }^{7}$ his life;

Because, on the day one meets death together,

${ }^{1}$ I.e., Qori Šilemün Taiši. See above, $\$ 170$.

2 For these events, see above, $\S \S 170-171,174$.

3 I.e., Heaven opened the way to Činggis' success.

${ }^{4}$ On his mission to the Onggirat. See above, $\$ 176$.

${ }^{5}$ See above, $\S \S 182-183,185$.

${ }^{6}$ I.e., the Kereyit.

${ }^{7}$ Lit., 'forsook.' 
He fought to the death,

Činggis Qa'an favoured Jürčedei and gave him Ibaqa Beki as wife. He said to Ibaqa, 'I did not say that you have a bad character and that in looks and appearance you are ugly. You, who have entered into my heart and limbs, and who have come to me taking your place in the rank of my principal wives, I present to Jürčedei in deference to the great principle whereby services are duly rewarded, to Jürčedei

Who, on the day we fought,

Was our shield,

Who against the enemy people

Was our shelter;

He brought together the people

Who had become divided,

He united the people

Who had scattered. ${ }^{1}$

I have given you to him being mindful of the principle of rewarding these services of his. In future, when my descendants sit on Our throne, mindful of the principle regarding services that have thus been rendered, they should not disobey my words. Until the offspring of $m y$ offspring, they are not to abolish Ibaqa's rightful place among my wives.' 2 So he ordered.

Činggis Qa'an said further to Ibaqa, 'Your father Jaqa Gambu gave you two hundred servants as dowry; he gave you also the steward Ašiq Temür and the steward Alčiq. Now you are going to the Uru'ut people; go, but give me one hundred out of your servants ${ }^{3}$ and the steward Ašiq Temür to remember you.' And he took possession of them.

Činggis Qa'an spoke again to Jürčedei and, showing favour to him, gave the following order: 'I give you my Ibaqa. As to your four thousand Uru'ut, you will be in charge of them, won't you?'

1 Cf. the words in $\$ \S 96$ and 104 above.

2 I.e., she would retain her former rank at court.

3 In the text ing yes for injes. See RSH 2.791-92. 


\section{THE SECRET HISTORY OF THE MONGOLS}

\section{CHAPTER NINE}

209 Further, Činggis Qa'an said to Qubilai, 'For me you pressed down

The necks of the mighty ones,

The buttocks of the strong ones.

You, Qubilai, J̌elme, J̌ebe and Sübe'etei ${ }^{1}$ - these "four hounds" of mine - when I sent you off, directing you to the place I had in mind, ${ }^{2}$

When I said, "Reach there!",

You crushed the stones to be there;

When I said, "Attack!",

You split up the rocks,

You shattered the shining stones,

You cleft the deep waters. ${ }^{3}$

When I sent you, Qubilai, J̌elme, J̌ebe and Sübe'etei, my "four hounds", to the place I had designated, if Bo'orču, Muqali, Boroqul and Čila'un Ba'atur - these "four steeds" 4 of mine - were at my side, and when the day of battle came and I had Jürčedei and Quyildar standing before me with their Uru'ut and Mangqut troops, then my mind was completely at rest. Qubilai, will you not be in charge of all military affairs?' So he ordered, favouring him.

Further, he said, 'Because of Bedü'ün's stubbornness, ${ }^{5}$ I was displeased with him and did not give him a unit of a thousand. You are the right person to manage him! You shall be the commander of a thousand with him and you will proceed in consultation with each other.' 6

1 Written Sübegetei.

2 Lit., 'which I had pointed out.'

3 Cf. above, $\$ \$ 72$ and 147.

4 See above, $\$ 163$.

5 See RSH 2.793-94.

6 See above, $\$ 191$. 
And he added, 'Afterwards We shall examine Bedü'ün's conduct. ${ }^{1}$

210 Further, Činggis Qa'an said to Qunan of the Geniges, 'For you, the commanders with Bo'orču and Muqali at their head, and for you, the chamberlains Dödei, Doqolqu and others, this Qunan was like

A male wolf in the dark night,

A black crow in the bright day:

When we were on the move he did not stop,

When we halted he did not move on.

With a stranger

He did not put on another face,

With a mortal enemy

He did not put on a different face.

Do not act without the agreement of Qunan and Kökö Čos. Act only in consultation with them.' So he ordered.

And he ordered, 'The eldest of my sons is Joči. Qunan, at the head of the Geniges, shall be a commander of ten thousand under J̌oči. Qunan, Kökö Čos, Degei and Old Üsün - these four are the four that never hid from me what they saw, never concealed from me what they heard.'

211 Further, Činggis Qa'an said to J̌elme, 'Old J̌arči’udai, carrying his bellows on his back - Jelme was still in the cradle - came down from Burqan Qaldun and gave sable swaddling-clothes when I was born at Deli'ün Boldaq on the Onan River. ${ }^{2}$ Since he became my companion, Jelme has been

The slave of $m y$ threshold,

The personal slave of $m y$ door. $^{3}$

J̌elme's merits are many. Fortunate and blessed J̌elme,

Who at birth was born together with me,

When growing, grew up together with $m e{ }^{4}$

and whose companionship with me has its origin in the

${ }^{1}$ For Bedü'ün see above, $\S 120$. There are no further references to him in the SH.

2 See above, $\$ 97$.

3 See above, $\S \S 137,180$.

4 See above, $\$ 204$. 
sable swaddling-clothes, he shall not incur punishment if he commits up to nine crimes.' So he ordered.

212 Further, Čnggis Qa'an said to Tolun, 'Why is it that you, father and son, will each be in charge of a separate thousand? When you gathered ${ }^{1}$ the people - you, Tolun, being one of the two wings of your father - you strove together and together gathered the people. It is, indeed, because of that that I gave you the title of chamberlain. ${ }^{2}$ Now, will you not form your own thousand with the people that you have acquired yourself and constituted as your own patrimony, and act in consultation with Turuqan?' So he ordered.

213 Further, Činggis Qa'an said to the steward Önggür, 'You, the three Toqura'ut and the five Tarqut, and you, Önggür, son of Mönggetü Kiyan, with your Čangši'ut and Baya'ut, have formed one camp for me. ${ }^{3}$ You, Önggür,

You did not go astray in the fog,

You did not separate from the others in the fight.

When it was wet

You suffered the wet with me;

When it was cold,

You suffered the cold with me. ${ }^{4}$

Now, what kind of reward will you take from me?' At this Önggür said, 'If you allow me to choose the reward, as my Baya'ut brothers are scattered about among all the various tribes, by your favour let me bring together my Baya'ut brothers.'

Thereupon, Činggis Qa'an ordered, 'Yes, be it so! Bring together your Baya'ut brothers and you take command - one thousand!' He said further, 'When you, the two stewards Önggür and Boro'ul, ${ }^{5}$ distribute food to the right and left sides,

Do not let it fall short

For those who stand or sit

I.e., 'conquered.'

2 Čerbi. See above, $\$ 191$.

3 See above, $\$ 120$.

${ }^{4}$ Cf. above, $\$ 207$.

${ }^{5}=$ Boroqul. 
On the right side;

Do not let it fall short

For those who are placed in a row -

Or who are not -

On the left side.

If you two distribute the food in this way, my throat will not choke and my mind will be at rest. Now, Önggür and Boro'ul, ride off and distribute food to the multitude.' So he ordered, and pointing out their seats, he said, 'When you take your seats, you must sit so as to look after the food on the right and the left sides of the large kumis pitchers. ${ }^{1}$ Sit with Tolun and the others in the centre of the tent, facing north.'

214 Again, Činggis Qa'an spoke to Boroqul, saying, 'As for Šigi Qutuqu, Boroqul, Güčü and Kököčü - the four of you - my mother

On the bare ground she found you,

In other people's camps.

She placed you close to her legs,

She treated you as her own sons

And brought you up with care;

She stretched your necks

And made you into adults;

She stretched your shoulders

And made you into men. ${ }^{2}$

She surely brought you up in order to make you the companions for us her sons. Who knows how many favours and services you have returned to my mother for the favour of having brought you up! Boroqul, you became my companion and

When we made swift sorties on rainy nights

You did not let me spend the night with an empty stomach; ${ }^{3}$

When we were engaged in battle with the enemy

You did not let me spend the night without soup.

1 I.e., of the wine table.

2 Lit. (here and just above) 'made you equal with (= to) a man' and ‘...a male' (RSH 2.802). Cf. below, §254.

${ }^{3}$ I.e., in spite of the difficulty of making a fire in the rain. 
Again, we crushed the Tatar people who, full of hatred and resentment, had destroyed our fathers and forefathers. At the time when

We were taking revenge,

We were requiting the wrong,

by killing the Tatar people to the last one, measuring them against the linchpin of a cart, ${ }^{1}$ and as they were being slain, Qargil Šira of the Tatar escaped and became an outcast. Then, reduced to straits and suffering from hunger, he came back and entering the tent said to my mother, "I am a beggar." "When he was told, "If you are a beggar, sit there", he sat at the end of the bench on the western side of the tent, near the inside of the door.

'At that moment, Tolui, who was five years old, came into the tent from outside. Then, as he ran out again, Qargil Šira rose and seizing the child pressed him under his arm. He went out and, as he was going forward feeling for and drawing out his knife, Boroqul's wife, Altani, was sitting on the eastern side of my mother's tent. When mother cried, "The boy is done for!", Altani followed her out and running together with her caught up with Qargil Šira: with one hand she seized his plaits and with the other she seized the hand that was drawing the knife. She pulled it so hard that he dropped the knife. At that very moment, north of the tent, J̌etei and J̌elme were killing a hornless black ox for provisions. At Altani's cry they both $^{3}$ came running, holding their butchering axes, their fists red with the animal's blood. With axe and knife they slew Qargil Šira of the Tatar on the spot.

'While Altani, J̌etei and J̌elme were arguing among the three of them whose chief merit it was for having saved the life of the child, Jetei and J̌elme said, "If we had not been there and if, by running fast and arriving in time, we had not killed him, what could Altani, a woman, have done? Qargil Šra would have harmed the life of the child. The chief merit is certainly ours!" Altani said, "If

1 See above, $\$ 154$.

2 Lit., 'a seeker of good things.'

3 Lit., 'J̌etei and J̌elme.' 
you had not heard my cry, how could you have come? And when I ran and caught up with him, seizing his plaits and pulling the hand that was drawing the knife, if the knife had not dropped, wouldn't he have done harm to the child's life before Jetei and Jelme arrived?" When she had finished speaking the chief merit went, by general consent, to Altani. Boroqul's wife became the second shaft of a cart for Boroqul and was useful in saving the life of Tolui.

'Again, when Boroqul was fighting with us against the Kereyit at the Qalaqaljit ${ }^{1}$ Sands, Ögödei was hit by an arrow in the neck vein and fell from his horse. Boroqul got off his horse and stopped by him, sucked the clotting blood with his mouth and spent the night with him. The following morning he put him on a horse, but as Ögödei could not sit up they rode double, Boroqul clasping Ögödei from behind and continuously sucking the woundclogging blood, so that the corners of his mouth were red with it; and so he came, bringing Ögödei back alive and safe. ${ }^{2}$ In return for my mother's suffering in bringing him up, he was indeed of service in saving the lives of my two sons. Boroqul was a companion to me: he never tarried

At $m y$ beck and call,

At $m y$ voice and its echo.

If Boroqul commits up to nine crimes he shall not be punished.' So he ordered. ${ }^{3}$

215 Further, Činggis Qa'an said, 'Let Us reward Our female offspring! ${ }^{4}$

216 Further, Činggis Qa'an said to Old Üsün, 'Üsün, Qunan, Kökö Čos and Degei, these four, without hiding or concealing, have always reported to me what they saw and heard; they have always informed me of what they

1 Qalqalyit in the text.

2 See above, $\$ 173$.

${ }^{3}$ There follows a sentence identical with that in $\$ 215$. This is due to a scribal error and should be deleted.

4 There is a lacuna here. The original text probably involved a set of ordinances and injunctions concerning grants and rewards to Činggis Qan's daughters and granddaughters. See RSH 2.807. 
thought and comprehended. In the Mongol tradition it is customary for a senior ranking personage to become a beki. ${ }^{1}$ You are a descendant of Elder Brother the Ba'arin. As to the rank of $6 e k i$, you Old Üsün, who are from among $u s$ and senior to Us, shall become a beki. When one has been raised to the rank of beki,

He shall wear a white dress

And ride a white gelding;

He shall sit on a high seat

And be waited upon.

Furthermore, yearly and monthly I shall hold discussions with you to seek your advice. ${ }^{2}$ Let it be so!' So he ordered.

217 Further, Činggis Qa'an said, 'Because of sworn friend Quyildar's service of first opening his mouth and speaking at the time of battle, ${ }^{3}$ disregarding ${ }^{4}$ his life, let his descendants to the offspring of his offspring receive the bounty granted to orphans. ${ }^{5}$ So he ordered.

218 Further, Činggis Qa'an said to Čaqān Qo'a's ${ }^{6}$ son Narin To'oril, 'Your father Čaqān Qo'a was fighting zealously before me at the battle of Dalan Baljut when he was killed by Jamuqa. ${ }^{7}$ Now, To'oril, for your father's services you shall receive the bounty granted to orphans.' To this To'oril said, 'If you are to favour me, as my Negüs brothers are scattered about among all the various tribes, by your favour let me bring together my Negüs brothers.' Thereupon, Činggis Qa'an ordered, 'If so, after having brought together your Negüs brothers, you will be in charge of them to the offspring of your offspring, won't you?' So he ordered.

${ }^{1}$ For this problematic title, seemingly an honorific one conferred on both men and women, see RSH 1.288-89 and sources there.

2 Cf. above, $\$ 204$.

3 See above, $\$ 171$.

4 Lit., 'forsaking.'

5 Cf. above, $\S 185$.

6 This is the same personage called Čaqa'an U'a (of the Ne'üs) in $\S \S 120$ and 129 above.

${ }^{7}$ See above, $\$ 129$. 
219 Further, Činggis Qa'an said to Sorqan Šira, 'At the time when I was small, when out of jealousy I was seized by Tarqutai Kiriltuq of the Tayiči'ut and his brothers, then you Sorqan Šra, because my kinsmen ${ }^{1}$ were jealous of me, ${ }^{2}$ with your sons Čila'un and Čimbai, made your daughter Qada'an take care of me, hid me and later, releasing me, you sent me away. ${ }^{3}$ Mindful of that good service of yours, whether

In the dark night in my dreams,

In the bright day in my heart, ${ }^{4}$

I certainly kept the memory of it; but you did come late to me from the Tayiči'ut. If I show favour to you now, what kind of favour do you wish?'

Sorqan Šira, who was together with his sons Čila'un and Čimbai, said, 'If you are to favour me, let me have the free use of grazing grounds. Let me settle on and freely use the territory of the Merkit on the Selengge River. As for other favours in addition to this, let Činggis Qa'an decide!'

To these words, Činggis Qa'an said, 'Settle on the territory of the Merkit on the Selengge and, indeed, have free use of its grazing grounds. You shall be a freeman, allowed to carry a quiver and drink the ceremonial wine to the offspring of your offspring. ${ }^{5}$ You shall not incur punishment for up to nine crimes.' So he ordered.

Further, Činggis Qa'an, showing favour to Čila'un and Čimbai, gave the following order: 'Thinking of the words that you, Čila'un and Čimbai, once spoke, how will

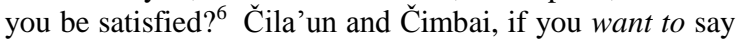
what you have in mind or request something that you lack, do not tell an intermediary about it. You in person, ${ }^{7}$ through your own mouths, tell me yourselves what you

${ }^{1}$ I.e., the Tayiči'ut. Cf. above, $\$ 76$.

2 See above, $\$ 82$.

3 See above, $\$ \S 85-87$.

${ }^{4}$ Cf. Jamuqa's words in $\$ 201$ above.

${ }_{6}^{5}$ For such privileges, see RSH 1.295, 2.811.

${ }^{6}$ Translation uncertain. See RSH 2.812-3.

${ }^{7}$ Lit., 'by your own bodies.' 
have thought, request from me yourselves what you lack.'

Further, he gave the following order: 'You, the freemen Sorqan Šira, Badai and Kišiliq, you too, as freemen,

When swiftly pursuing many foes,

If you get booty,

What you get you shall take away.

When in a battue

You hunt wild beasts,

What you slaughter you shall take away. ${ }^{1}$

As for Sorqan Sira, he was but a retainer of Tödege of the Tayiči'ut. ${ }^{2}$ Badai and Kišiliq were but horse-herders of Čeren. $^{3}$ Now, with my support, enjoy the privilege of being freemen, allowed to carry a quiver and drink the ceremonial wine!'

220 Further, Činggis Qa'an said to Naya'a, 'When Old Širgötï, ${ }^{4}$ together with you - his sons Alaq and Naya'a seized Tarqutai Kiriltuq and, proceeding on his way to us, arrived at the Qutuqul Bend, Naya'a there and then said, "How can we go on, seizing and making away with our rightful lord?" And, unable to make away with him, you set him free and sent him away.

'When Old Širgōtü, together with you - his sons Alaq and Naya'a - arrived, then Naya'a Bilȳi'ür said, "We laid hands on our rightful lord Tarqutai Kiriltuq and were coming here, but we could not make away with him. We set him free and sent him off, and came to offer our services to Činggis Qa'an. We said to ourselves that had we come having laid hands on our lord, it would have been said of us: 'People who have laid hands on their rightful lord - how can they be trusted in future?' So, we could not make away with our lord."

'Then, because the reason why he could not make away with his rightful lord was the fact that he had been

${ }^{1}$ Cf. above, $\$ 187$.

2 See above, $\$ 146$.

${ }^{3}$ I.e., Yeke Čeren. See above, $\$ 169$.

${ }^{4}$ The Širgü'etü of $\S 149$, where this event is narrated. 
mindful of the great principle, ${ }^{1} \mathrm{I}$ approved of his words and said, "I shall entrust him with an important task." Now, Bo'orču will be in charge of the ten thousand of the right wing; and I put Muqali in charge of the ten thousand of the left wing, giving him the title of gui ong. ${ }^{3}$ Now, Naya'a will be in charge of the ten thousand of the centre.' So he ordered.

221 Further, Činggis Qa'an said, 'Jebe and Sübe'etei shall each be commanders of a thousand over as many of those people that ${ }^{4}$ they themselves have acquired and constituted as their own patrimony.'

222 Further, Činggis Qa'an made the shepherd Degei bring together the unregistered households and put him in charge of a thousand.

223 Further, Činggis Qa'an said, 'As the carpenter Güčügür ${ }^{5}$ lacks subjects to form a unit of a thousand, let these be collected from here and there and given to him. Since, from among the Jadaran, Mulqalqu has been a perfect companion to me, you two - Güčügür and Mulqalqu - be jointly in command of a thousand and consult with one another.'

224 Ćnggis Qa' an made commanders of a thousand those who had established the state with him and who had suffered with him. Forming units of a thousand, he appointed the commanders of a thousand, of a hundred and of ten. Forming units of ten thousand, he appointed the commanders of ten thousand. The commanders of ten thousand and of a thousand to whom reward seemed appropriate, he rewarded; those who were to be commended, he commended. He gave them the following order: 'Formerly, I had eighty men to serve on roster as nightguards and seventy men to serve as dayguards. Now, by the strength of Eternal Heaven, my strength and

${ }^{1}$ I.e., the principle of mutual obligations between lord and subject. Cf. above, $\$ 208$.

2 Cf. above, $\$ 149$.

3 See above, \$202 and RSH 2.761-2.

4 Lit., 'as many of theirs as.'

5 The Küčügür of $\S 120$. See also above, $\S \S 124$ and 202. 
power have been increased by Heaven and Earth and I have brought the entire people to allegiance, causing them to come under my sole rule, ${ }^{1}$ so now choose men to serve on roster as dayguards from the various thousands and recruit them for me. When you recruit them and have nightguards, quiverbearers and dayguards enrolled, recruit them so as to make up a full ten thousand.' So he ordered.

Further, Činggis Qa'an proclaimed the following order to the various thousands regarding the selection and recruitment of the guards: 'When guards will be recruited for Us, and the sons of commanders of ten thousand, of a thousand and of a hundred, or the sons of ordinary people, will enter Our service, those shall be recruited who are able and of good appearance, and who are deemed suitable to serve by Our side. When recruiting the sons of commanders of a thousand, they shall each bring with them ten companions and one younger brother. When recruiting the sons of commanders of a hundred, they shall each bring with them five companions and one younger brother. When recruiting the sons of commanders of ten, or the sons of ordinary people, they shall each bring with them three companions and, likewise, one younger brother; and they shall be provided with fully equipped mounts supplied by the units to which they originally belonged. When strengthening in this guise the number of those who will be placed to serve by Our side, the ten companions to be given to each of the sons of the commanders of a thousand must be drawn from the units of a thousand and the units of a hundred from which they originally came. Whether or not they have a share of goods given by their fathers and regardless of the number of men and geldings that they have personally acquired and constituted as their own patrimony, a levy shall be raised - independently of their personal share of goods of mounts and men according to the amount fixed by Us and, levying men and preparing mounts in this manner,

\footnotetext{
${ }^{1}$ Lit., 'to enter into my only reins (= control).' See RSH 2.820.
} 
they shall be given to them. And exactly in the same manner, independently of their personal share of goods and levying in precisely the same way, five companions each shall be given to the sons of commanders of a hundred, and three companions each to the sons of commanders of ten, as well as to the sons of ordinary people.' So he ordered.

And he ordered, 'As to the commanders of a thousand, of a hundred and of ten, and the numerous ordinary people who have received this order of Ours, or who have heard it, anyone who transgresses it shall be guilty and liable to punishment. As to the people who have been recruited to serve on roster for Us, if any of them are unsuitable for duty because they evade it, regarding their service by Our side as too difficult, we shall recruit others in their stead and we shall punish those people and send them to a distant place, out of Our sight.'

And he said, 'People who come to Us in order to learn to serve inside the tent by Our side shall not be hindered.'

225 Since Činggis Qa'an had issued an order, choosing guards from the units of a thousand and, according to the same order, choosing the sons of commanders of a hundred and of ten, as they came forward - formerly there were only eighty nightguards - he brought their number up to eight hundred. And he said, 'On top of the eight hundred, add to the number so as to make up a full thousand.'

He ordered, 'Those who want to enrol in the nightguards shall not be hindered.' And he ordered, 'Yeke $\mathrm{Ne}$ 'ürin shall be the commander of the nightguards and he shall be in charge of a thousand.'

Earlier four hundred quiverbearers had been chosen. Choosing them anew, he said, 'Yisün Te'e, the son of Jelme, shall be the commander of the quiverbearers and he shall act in consultation with Tüge's ${ }^{1}$ son, Bügidei.'

1 This Tüge is the Tüngge of $\S 137$ and the Tüge of $\$ 202$ above. Although there is no previous mention of the four hundred quiverbearers, see $\S 192$ above for their duties. 
And he ordered, 'When the quiverbearers together with the dayguards join to form the various companies, ${ }^{1}$ Yisün Te'e shall join as the commander of one company of quiverbearers; Bügidei shall join as the commander of one company of quiverbearers; Horqudaq shall join as the commander of one company of quiverbearers; and Lablaqa shall join as the commander of one company of quiverbearers. These four shall make their quiverbearers join the various companies of dayguards to carry quivers and so be their commanders. Yisün Te'e shall add to the number of quiverbearers to make up a full thousand and be the overall commander.'

226 Cinggis Qa'an, bringing the number of dayguards who had formerly enrolled with Ögele Čerbi up to a full thousand, said, 'Ögele Čerbi from the family of Bo'orču shall be in charge of them.' He said, 'As for one thousand dayguards, Buqa from the family of Muqali shall be in charge of them.' ${ }^{2}$ He said, 'Alčidai from the family of Ilügei shall be in charge of one thousand dayguards.' He said, 'Dödei Čerbi shall be in charge of one thousand dayguards and Doqolqu Čerbi shall be in charge of one thousand dayguards.' And he ordered, 'Čanai from the family of Jürčedei shall be in charge of one thousand dayguards; Aqutai from the family of Alči shall be in charge of one thousand dayguards; Arqai Qasar shall be in charge of one thousand dayguards - one thousand chosen brave warriors - who, in the many days of peace shall serve as dayguards, and in the days of battle shall stand before me and be brave warriors.'

Thus, there were eight thousand dayguards chosen from the various thousands; there were also two thousand nightguards with quiverbearers. Altogether there were ten thousand guards.

Činggis Qa'an ordered, 'The ten thousand guards attached to Us shall be strengthened and become the main body of the army.' So he ordered.

227 Further, when Činggis Qa'an issued the order ap-

1 I.e., the separate watches.

2 Lit., 'of one thousand dayguards.' 
pointing those who were to be the elders ${ }^{1}$ of the four companies of dayguards on roster duty, he said, 'Buqa shall be in charge of one company of guards; he shall marshal them ${ }^{2}$ and take his turn of duty. Alčidai shall be in charge of one company of guards; he shall marshal them and take his turn of duty; Dödei Čerbi shall be in charge of one company of guards; he shall marshal them ${ }^{3}$ and take his turn of duty. Doqolqu Čerbi shall be in charge of one company of guards; he shall marshal them ${ }^{3}$ and take his turn of duty.' So he appointed the elders of the four companies on roster duty.

Cinggis Qa'an promulgated the order about taking turns of duty, saying, 'On taking his turn of duty, the commander of the company will himself muster the guards who are to serve on roster and then take his turn of duty; after spending three days and nights with them the company shall be relieved. If a member of the Guard fails to take his turn, the guard that has so failed shall be disciplined with three strokes of the rod. If the same guard fails again - for the second time - to take his turn of duty, he shall be disciplined with seven strokes of the rod. If, once more, the same man, without being sick in body and without having first consulted the commanders of the company, if the same guard fails once more - that is three times - to take his turn of duty, thus regarding his service by Our side as too difficult, he shall be disciplined with thirty-seven strokes of the rod and shall be sent to a distant place, out of Our sight.' So he ordered.

And he ordered, 'The elders of the companies shall proclaim this order to the guards every third turn of duty. If the elders of the companies do not proclaim it they shall be guilty and liable to punishment. When the guards have heard the order, if they contravene it and fail to take their turn of duty according to the order they shall be guilty and liable to punishment.' So he ordered.

He said, 'Elders of the companies, do not reprimand

1 I.e., the senior officers.

${ }^{2}$ Lit., 'the guards'; i.e. he shall dispose them in due order.

3 Lit., 'the guards.' 
my guards, who have enrolled as guards equal to you, without my permission and merely on the ground of seniority. If any of them breaks the law report it to me. Those liable to execution We shall certainly cut down. Those liable to be beaten We shall certainly compel to lie down and have them beaten. If you yourselves merely on the ground of seniority lay hands on my guards who are equal to you and strike them with a rod, as requital for strokes of the rod you shall be repaid with strokes of the rod, and as requital for fists you shall be repaid with fists.'

228 Further, Ćinggis Qa'an ordered, 'My guards are of higher standing than the outside commanders of a thousand; the attendants of my guards are of higher standing than the outside commanders of a hundred and of ten. If outside leaders of a thousand, regarding themselves as equal to and a match for my guards, quarrel with them, We shall punish the persons who are leaders of a thousand.' So he ordered.

229 Further, Činggis Qa'an issued the following order and proclaimed it $^{1}$ to the commanders of the various companies: 'When the quiverbearers, the dayguards and the stewards take their turn of duty, they shall carry out their day duties, each at his respective post. As the sun sets, they shall retire so as to be replaced by the nightguards and, going outside, they shall spend the night there. At night, the nightguards shall spend the night beside Us. The quiverbearers shall leave, turning over their quivers and the stewards their bowls and vessels - to the nightguards. The following morning, the quiverbearers, dayguards and stewards who have spent the night outside shall stay at the horse station while We eat Our soup; then, they will report to the nightguards. When We have finished eating Our morning soup, the quiverbearers shall return to their quivers, the dayguards to their appointed place and the stewards to their bowls and vessels. Those who take their turn of duty on roster must all act thus, in precisely the same manner, according to this ordinance.'

1 Lit., 'the order.' 
So he ordered.

He said, 'Any person who moves about crosswise at the rear or front of the Palace after sunset shall be arrested and the nightguards shall hold him in custody for the night. The following morning, the nightguards shall question him. When the company is relieved, the incoming nightguards shall hand over their passes and only then come in and take their turn of duty; the outgoing nightguards when relieved shall likewise hand theirs over and depart.'

He said, 'The nightguards at night lie down all around the Palace; you, nightguards who stand guarding the door, shall hack any persons entering at night until their heads are split open and their shoulders fall apart, then cast them away. If any persons come at night with an urgent message, they must report to the nightguards and communicate the message to me while standing together with the nightguards at the rear ${ }^{1}$ of the tent.'

'No one is to sit in a place above the nightguards. ${ }^{2}$ No one is to enter the precinct without permission from the nightguards. No one is to walk up beyond the nightguards. One must not walk between the nightguards. One must not ask the number of nightguards. The nightguards shall arrest the people who walk up beyond them. ${ }^{3}$ The nightguards shall arrest the people who walk between them. And the nightguards - with regard to any person who shall have asked their number - the nightguards shall seize the gelding that that person was riding that very day, with saddle and bridle, together with the clothes that he was wearing.' So he ordered.

Elǰigedei, ${ }^{4}$ even though he was a trustworthy person, was he not arrested by the nightguards when in the evening he happened to walk up beyond them?

1 I.e., at the northern side.

2 I.e., between the nightguards and the tent.

3 Lit., 'the nightguards.'

4 The Elyjigidei of $\$ \$ 275$ and 278 below. 


\title{
THE SECRET HISTORY OF THE MONGOLS
}

\author{
CHAPTER TEN
}

230 Činggis Qa'an said,

'My elder nightguards who, in the cloudy night,

Lying down around my vented tent ${ }^{1}$

Ensured that I slept in quiet and peace,

You have made me gain this throne. ${ }^{2}$

My blessed nightguards who, in the starry night,

Lying down all around my Palace tent,

Ensured that I was without fear in my bed,

You have made me gain the high throne.

My true-hearted nightguards who in the swirling snowstorm,

In shivering cold, in pouring rain, taking no rest,

Stood all around my latticed tent

Bringing peace to my heart,

You have made me gain this throne of joy.

My trustworthy nightguards, who in the midst

Of trouble-making enemies, not blinking an eye,

Stood all around my felt-girt tent

Withstanding their onslaught;

My watchful nightguards who, hearing the enemy's

Quivers of birch-bark barely rattling,

Stood up without delay;

My swift-moving nightguards who, hearing the enemy's

Quivers of willow-wood barely rattling,

Stood up not a moment too late;

My blessed nightguards, from now on

You shall call yourselves "the elder nightguards."

The seventy dayguards who had enrolled with Ögöle

I.e., a tent with a smoke-hole at the top.

${ }^{2}$ See above, $\$ 205$. 
Čerbi ${ }^{1}$ shall be called "the great dayguards." The brave warriors of Arqai $^{2}$ shall be called "the elder brave warriors." The quiverbearers Yisün Te'e, Bügidei and the others shall be called "the great quiverbearers." So he ordered.

231 Cinggis Qa'an said, 'As for my ten thousand personal guards who have come to serve in my presence, chosen for personal service from the ninety-five thousand, ${ }^{3}$ you, sons of mine who will later sit on my throne to the offspring of my offspring, considering these guards as a keepsake from me, give them no cause for dissatisfaction, but take good care of them! These ten thousand guards will they not be called my beneficent spirits? ${ }^{4}$

232 Further, Činggis Qa'an said, 'The nightguards shall be in charge of the female attendants ${ }^{5}$ of the Palace, the "sons of the household", 6 the camel-keepers and the cowherds, and they shall take care of the tent-carts of the Palace. The nightguards shall take care of the standards and drums, and the spears arranged beneath them. The nightguards shall also take care of the bowls and vessels. The nightguards shall supervise Our drink and food. The nightguards shall supervise and cook the uncut meat and food as well: if drink and food are lacking, we shall seek them from the nightguards who have been entrusted with their supervision.' And he said, 'When the quiverbearers distribute drink and food, they must not distribute them without permission from the supervising nightguards. When they distribute food, they shall first distribute it beginning with the nightguards.' And he said, 'Entering into and going out from the Palace tent must be regulated by the nightguards. At the door, the doorkeepers from the nightguards shall stand right next to the tent. Two from the nightguards shall enter into the tent and oversee the

\footnotetext{
See above, $\S 120$.

I.e., Arqai Qasar.

See above, $\$ 202$.

See above, $\$ 207$.

Čerbin ökit. See RSH 2.835.

${ }^{6}$ I.e., young domestic slaves.
} 
large kumis pitchers.' And he said, 'The campmasters from the nightguards shall go before $U s$ and set up the Palace tent.' And he said, 'When We go falconing or hunting, the nightguards shall go falconing and hunting with Us; but exactly one half of them shall stay at the carts.'

233 Further, Činggis Qa'an said, 'If We Ourselves do not go on a military campaign the nightguards must not take the field without Us.' So he said, and gave the following order: 'After being thus instructed by Us, the chamberlains in charge of troops who transgress the order and, out of jealousy for the nightguards, send them out on campaign, shall be guilty and liable to punishment.' And he said, 'You say, "Why is it that soldiers from the nightguards are not sent out on campaign?" It is the nightguards that watch over my golden ${ }^{1}$ life. When I go falconing or hunting, they toil with me; being charged with the administration of the Palace, whether this is moving or stationary, they look after the carts. Is it an easy thing to spend the night watching over my person? Is it an easy thing to look after the tent-carts when the main base camp is in movement or settled? The reason why We say that they ${ }^{2}$ must not take the field separately and without Us, is because We say to Ourselves that they have already so many and quite distinct duties.'

234 Further, Činggis Qa'an gave the following order: 'Some of the nightguards shall decide on judicial matters together with Šigi Qutuqu.' And he said, 'Some of the nightguards shall take care of quivers, bows, breastplates and weapons, and they shall distribute them. Managing some of the geldings, they shall load the hunting nets on to them.' And he said, 'Some of the nightguards, together with the chamberlains, shall distribute the satin.' And he said, 'When the quiverbearers and the dayguards have reported on the establishment of the encampment, the quiverbearers such as Yisün Te'e and Bükidei, and the dayguards such as Alčidai, Ögöle and Aqutai, shall take

${ }^{1}$ I.e., royal.

${ }^{2}$ I.e., the nightguards. 
up duty on the right ${ }^{1}$ side of the Palace.' And he said, 'The dayguards such as Buqa, Dödei Čerbi, Doqolqu Čerbi and Čanai shall take up duty on the left ${ }^{2}$ side of the Palace.' And he said, 'Arqai's brave warriors shall take up duty in front ${ }^{3}$ of the Palace.' And he said, 'The nightguards, having taken care of the tent-carts of the Palace, shall take up duty in the proximity of the Palace, on the left ${ }^{2}$ side.' And he said, 'Dödei Čerbi shall constantly supervise the Palace: all the guards who are dayguards, and, round about the Palace, the "sons of the household" of the Palace, the horse-herders, shepherds, camel-keepers and cowherds. ${ }^{4}$ He appointed him and gave the following order: 'Dödei Čerbi shall take up duty and be constantly present, at the rear ${ }^{5}$ of the Palace,

Eating scraps of leftovers,

Burning dried dung., ${ }^{6}$

235 Cinggis Qa'an sent Qubilai Noyan to fight against the Qarlu'ut. Arslan Qan of the Qarlu'ut came to submit to Qubilai. Qubilai Noyan took Arslan Qan back with him and made him pay homage to Činggis Qa'an. Because he had not opposed resistance, Činggis Qa'an showed favour to Arslan and said, 'I shall give him a daughter in marriage.'

236 Sübe'etei Ba'atur, who had been provided with an iron cart, ${ }^{7}$ had gone on a campaign in pursuit of the sons of Toqto'a of the Merkit led by Qutu and Čila'un. He overtook them at the Čui River, destroyed them and came back.

237 J̌ebe, pursuing Güčülük Qan of the Naiman, overtook him at Sariq Qun. ${ }^{8}$ He destroyed Güčülük and came back.

1 I.e., western.

2 I.e., eastern.

3 I.e., at the southern side.

4 See above, $\$ 232$.

5 I.e., at the northern side.

6 For fuel.

7 See above, $\$ 199$.

${ }^{8}$ I.e., 'Yellow Cliff'; possibly an error for Sariq Qol. See RSH 2.844-45. 
238 The idu'ut of the Ui'ut ${ }^{1}$ sent envoys to Činggis Qa'an. Through the envoys Atkiraq and Darbai he had the following petition conveyed to him:

'As if one saw Mother Sun

When the clouds disperse;

As if one came upon the river water

When the ice disappears, ${ }^{2}$

so I greatly rejoiced when I heard of the fame of Činggis Qa'an. If through your favour, O Činggis Qa'an, I were to obtain

But a ring from your golden belt,

But a thread from your crimson coat, I will become your fifth son and will serve you.'

Činggis Qa'an, in reply to those words and showing favour to him, sent the following message: 'I shall give him a daughter and let him become my fifth son. The idu'ut must come, bringing with him gold, silver, small and big pearls, brocades, damasks and silks.' The idu'ut rejoiced because he had been favoured; and taking with him gold, silver, small and big pearls, silks, brocades, damasks and satins, $\mathrm{he}^{3}$ came and paid homage to Činggis Qa'an. Činggis Qa'an favoured the idu'ut and gave him his daughter Al Altun in marriage.

In the Year of the Hare (1207), Činggis Qa'an sent Joči with the troops of the right wing on an expedition against the People of the Forest. Buqa went with him acting as a guide. Quduqa Beki of the Oyirat came to submit ahead of the Tümen Oyirat. He came and, acting as a guide, led J̌či to the territory of the Tümen Oyirat and made them submit at the Šiqšit River. ${ }^{4}$ Joči brought the Oyirat, Buriyat, Barqun, Ursut, Qabqanas, Qangqas and Tubas under submission.

When he reached the territory of the Tümen Kirgisut,

\footnotetext{
I.e., the ruler of the Uighurs.

2 I.e., melts.

3 Lit., 'the idu'ut.'

4 The Šsgis River of $\S 44$ above.
} 
their ${ }^{1}$ leaders Yedi Inal, Aldi Er and Örebek Digin - these leaders of the Kirgisut - came to submit. Bringing with them gifts of white gerfalcons, white geldings and black sables, they paid homage to J̌oči.

After Joči had subjugated the People of the Forest from the Šibir, Kesdim, ${ }^{2}$ Bayit, Tuqas, Tenlek, ${ }^{3}$ Tö'eles, ${ }^{4}$ Tas and Bajigit up to this side, ${ }^{5}$ he came back bringing with him the commanders of ten thousand and of thousands of the Kirgisut and the leaders of the People of the Forest. He caused them to pay homage to Činggis Qa'an with gifts of white gerfalcons, white geldings and black sables.

Činggis Qa'an welcomed Quduqa Beki of the Oyirat, saying, 'He came to submit before the others, leading the Tümen Oyirat.' And he showed favour to him, giving Čečeyigen to his son Inalči. He gave J̌oči's daughter Qoluiqan $^{6}$ to Törölči, elder brother of Inalči. He gave Alaqa Beki to the ruler of the Önggüt.

Činggis Qa'an favoured J̌oči, saying, 'You, eldest of my sons, who only now for the first time have left home, you have been lucky. Without wounding or causing suffering to man or gelding in the lands where you went, you came back having subjugated the fortunate ${ }^{7}$ People of the Forest. I shall give this people to you.' So he ordered.

240 Further, he sent Boro'ul Noyan to fight against the Qori Tumat people. As Daiduqul Soqor, the leader of the Tumat people, had died, his wife Botoqui Tarqun was governing them. ${ }^{8}$ Upon reaching their territory, Boroqul Noyan with two others - three men altogether - set out

1 Lit., 'of the Kirgisut.'

2 Written Kesdiyim.

3 Read Teleng (pl. Telengüt; cf. §207), the modern Telengit of the Altai Republic (RSH 2.853).

4 The Tö'ölös of $\$ 207$ above.

5 I.e., 'up to our side (= territory).'

${ }^{6}$ Huluiqan in the text.

${ }^{7}$ Because they had peacefully submitted to the Mongols, thus gaining Činggis' favour.

${ }^{8}$ Lit., 'the Tumat people.' 
from the main army to proceed ahead of it. In the evening, as they were going along a trail in the dense forest and were off guard, they were attacked from the rear by their ${ }^{1}$ patrolmen, who blocked the trail. Boroqul Noyan was caught and killed.

When Čnggis Qa'an learnt that the Tumat had killed Boroqul, he was greatly angered and prepared to move in person against them, but Bo'orču and Muqali pleaded with him $^{2}$ until he desisted. Thereupon he appointed Dörbei Doqšin of the Dörbet and commanded him thus: 'Set the army in strict order, pray to Eternal Heaven and strive to subdue the Tumat people!'

Dörbei set the army in order and beforehand made a decoy manoeuvre ${ }^{3}$ along the paths, trails and passes where the army was expected to advance and which enemy patrols would keep under surveillance. Then, going by paths trodden by the red bull, ${ }^{4}$ he issued an ordinance to his warriors that, with regard to all the men in the army, if anyone lost heart and refused to proceed, they should beat him, and he made each man carry ten rods for this purpose; he also had axes, adzes, saws, chisels and weapons prepared for the men. Along the paths trodden by the red bull he had them chop, hew and saw the trees that stood in the way, thus making a road for the army to pass.

They went up the mountain and, as though falling on to the smoke-hole of the tents ${ }^{5}$ of the Tumat people who were busy feasting, they took them by surprise and plundered them.

241 Earlier Qorči Noyan and Quduqa Beki had been seized by the Tumat and were there, with Botoqui Tarqun. The way in which Qorči was seized was the following: When Cinggis Qa'an said, 'The girls of the Tumat people

1 I.e., the Tumat's.

2 Lit., 'Činggis Qa'an.'

3 Lit., 'falsely caused troops to move.'

4 Probably a large deer or an elk is meant.

5 For this simile, referring to a surprise attack that comes as though falling from the sky on the roof of one's tent, cf. above, $\S \S 105$ and 109. 
are beautiful; let him take thirty wives ${ }^{1}$ from among them!', Qorči went, intending to take the girls of the Tumat people, but these people, who had formerly submitted, now rebelled and seized Qorči Noyan.

When Činggis Qa'an learnt that Qorči had been seized by the Tumat, he said, 'Quduqa knows the ways and manners of the People of the Forest', and sent him to them, but Quduqa Beki was also seized.

After he had brought the Tumat people completely under submission, Ćinggis Qa'an, because of the death ${ }^{2}$ of Boroqul gave one hundred Tumat to his family. Qorči took thirty girls. Činggis Qa'an gave Botoqui Tarqun to Quduqa Beki.

242 Činggis Qa'an decreed that he would apportion the subject people among his mother, children and younger brothers. When he gave them their share, he said, 'The one who toiled most gathering ${ }^{3}$ the people was mother. The eldest of my sons is Joči. The youngest of my younger brothers is Otčigin.' To his mother, together with Otčigin's share, he gave ten thousand people. The mother was dissatisfied, thinking them too few, but she did not complain.

To J̌oči he gave nine thousand people. To Ča'adai he gave eight thousand people. To Ögödei he gave five thousand people. To Tolui he gave five thousand people. To Qasar he gave four thousand people. To Alčidai he gave two thousand people. To Belgütei he gave one thousand five hundred people.

He said, 'Dāritai joined the Kereyit. ${ }^{4}$ I shall wipe him from my sight.' On that, Bo'orču, Muqali and Šigi Qutuqu spoke saying, 'This action would be

Like extinguishing one's own hearth-fire,

Like destroying one's own tent.

As a reminder of your good ${ }^{5}$ father, only your paternal

\footnotetext{
Lit., 'thirty women.'

Lit., 'bones.'

I.e., rallying.

${ }^{4}$ Gereyit in the text.

5 I.e., 'late.'
} 
uncle is left. How can you do away with him? He acted without thinking, so spare him. Allow the youngest brother of your good father, together with his people, to let the smoke of their camp swirl up!' And they reasoned with him until he was so moved that

He snuffled, as if

He had smoke in his nose.

'Right!' - he said, and thinking of his good father, he calmed down at the words of Bo'orču, Muqali and Šigi Qutuqu.

243 Cinggis Qa'an said, 'I have given ten thousand people to mother and to Otčigin, and for them I have appointed the four commanders Güčü, Kököčü, Jungsai and Qorqasun. For Joči I have appointed the three commanders Qunan, Möngke'ür and Kete. For Ča'adai I have appointed the three commanders Qaračar, Möngke and Idoqudai.'

Further, Činggis Qa'an said, 'Ča'adai is headstrong and is, by nature, punctilious. Köke Čos shall stay at his side evening and morning, and shall tell him what he thinks.' So he ordered.

For Ögödei he appointed both Ilüge and Degei. For Tolui he appointed both Jedei and Bala. For Qasar he appointed J̌ebke. For Alčidai he appointed Ča'urqai. ${ }^{2}$

244 The sons of Father Mönglik of the Qongqotan were seven. The middle one was Kököčü Teb Tenggeri. Those seven ganged up and beat Qasar.

When Qasar, kneeling before Činggis Qa'an, told him that he had been beaten by the seven Qongqotan who had ganged up against him, Činggis Qa'an was angry about other matters. While Qasar was still talking, Činggis Qa' an in his anger said to him, 'In the past you have done nothing but claim that you would not be vanquished by any living being. How is it that you have now been vanquished?' At this Qasar wept, then rose and left.

Qasar was vexed and for three days in succession did

1 I.e., 'he shall advise him.'

2 Some of the names in this section appear elsewhere in the $\mathrm{SH}$ in slightly different forms. See RSH 2.868. 
not come before Činggis Qa'an.

After this, Teb Tenggeri said to Činggis Qa'an, 'The decree of Eternal Heaven concerning the ruler has been foretold by heavenly signs ${ }^{1}$ as follows: once they say that Temüjin will hold the nation, once that ${ }^{2}$ Qasar will. If you don't strike at Qasar by surprise, there is no knowing what will happen!'

On these words, Činggis Qa'an that very night rode off to seize Qasar. When he left, Güčü and Kököčü informed the mother ${ }^{3}$ that he had gone to seize Qasar. When the mother heard this, straightaway - it was still night - she harnessed a white camel and set out in a black covered cart, travelling all night.

On her arrival at sunrise, Činggis Qa'an had tied up the opening of Qasar's sleeves, removed his hat and belt, and was interrogating him. Činggis Qa'an, surprised by the mother descending upon him, became afraid of her. ${ }^{4}$

The mother was furious. As soon as she got there and dismounted from the cart, she ${ }^{5}$ herself untied and loosened Qasar's sleeves, the opening of which had been tied up, and gave back to Qasar his hat and belt. The mother was so angered that she was unable to contain her fury. She sat cross-legged, took out both her breasts, laid them over her knees and said, 'Have you seen them? They are the breasts that suckled you, and these ${ }^{6}$ are the ones who, rushing out of my womb, ${ }^{7}$

Have snapped at their own afterbirth, ${ }^{8}$

Have cut their own birth cord.

What has Qasar done? Temüjin used to drain this one breast of mine. Qači'un and Otčigin between them did not drain a single breast. As for Qasar, he completely

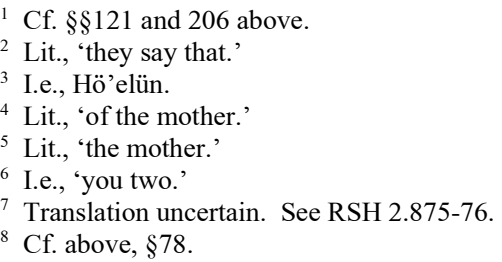


drained both my breasts and brought me comfort until my bosom relaxed. He used to make my bosom relax. Therefore,

My able Temüǰin

Has skill of mind. ${ }^{1}$

My Qasar has skill in archery

And might, and so he was wont

To shoot and subdue

All those on the run, shooting at him.

With long-distance arrows he was wont

To shoot and subdue

All those on the run, in fear of him.

But now, saying that you ${ }^{2}$ have destroyed the enemy people, you can no longer bear the sight of Qasar.' So she spoke.

After Činggis Qa'an had at last calmed the mother, he said, 'I was afraid of mother getting so angry and really became frightened; and I felt shame and was really abashed.' And saying, 'Let us withdraw!', he withdrew and returned home. But, without letting the mother know, he stealthily took away the subjects ${ }^{3}$ of Qasar and let Qasar have only one thousand four hundred people. That is how, when the mother learned this, the thought of it made her go quickly into decline. Jebke of the Jalayir then left in fright and fled into the Barqujin Lowland.

245 After that, the 'people of nine tongues' ${ }^{4}$ gathered under Teb Tenggeri. Many from Činggis Qa'an's horse station also decided to gather under Teb Tenggeri. When they had thus gathered, the people who were subject to Temüge Otčigin went over to Teb Tenggeri. Otčigin Noyan then sent his messenger, by name of Soqor, to request the return of the people who had departed. Teb Tenggeri said to the messenger Soqor, 'I am grateful to

1 Lit., 'of bosom.'

2 I.e., Temüj̆in.

3 Lit., 'the people.'

4 Possibly Kereyit tribesmen distributed among the Mongols. See RSH 2.878-80. 
both Otčigin and you', ${ }^{1}$ and, after beating him, sent the messenger Soqor back on foot, forcing him to carry his saddle on his back.

Greatly affected by the beating of his messenger Soqor and his returning on foot, Otčigin the following day - Otčigin himself - went to Teb Tenggeri and said, 'I sent my messenger Soqor to you, but you beat him and sent him back on foot. Now I have come myself to request the return of my people.'

On that, the seven Qongqotan from all sides surrounded Otčigin, saying, 'You were right to send your messenger Soqor.' Otčigin Noyan, being dealt with in this way and fearing to be seized and beaten by them, said, 'I was wrong to send my messenger.' The seven Qongqotan then said, 'If you were wrong, kneel down and make amends', and they had him kneel down behind Teb Tenggeri.

Otčigin was not given his people; so, early next day, when Činggis Qa'an had not yet got up and was still in bed, he ${ }^{2}$ went into his tent. He wept and, kneeling down, said, "As "the people of nine tongues" had assembled under Teb Tenggeri, I sent a messenger called Soqor to request from Teb Tenggeri the return of the people subject to me. They beat my messenger Soqor, they made him carry the saddle on his back, and he was sent back on foot. When I in person went to request the return of my people, I was surrounded from all sides by the seven Qongqotan, who compelled me to make amends and kneel down behind Teb Tenggeri.' And he wept.

Before Činggis Qa'an could utter a sound, Lady Börte sat up in bed, covering her breasts with the edge of the blanket. Seeing Otčigin weep, she herself shed tears and said, 'What are those Qongqotan doing? They recently ganged up and beat Qasar. And now, why do they make this Otčigin kneel down behind them? What kind of behaviour is this? Thus they covertly injure even these younger brothers of yours who are like cypresses and

1 For the gift of the horse - said sarcastically, of course.

2 I.e., Otčigin. 
pines. And truly, later

When your body, like a great old tree,

Will fall down,

By whom will they let govern your people

Who are like tangled hemp?

When your body, like the stone base of a pillar,

Will collapse,

By whom will they let govern your people

Who are like a flock of birds?

How will people covertly injuring in this fashion your younger brothers, who are like cypresses and pines, ever allow my three or four little "naughty ones"1 to govern while they are still growing up? What are those Qongqotan doing? Now that you have let them ill-treat your younger brothers in such a way, how do you view all this?' So spoke Lady Börte and shed tears.

On these words of Lady Börte, Činggis Qa'an said to Otčigin, 'Teb Tenggeri is coming now. Whatever you may wish to do to him within your power, it is for you to decide!' Whereupon Otčigin rose, wiped away his tears and, going out of the tent, stood in readiness with three strong men.

After a while, Father Mönglik came with his seven sons. The seven all entered and, as Teb Tenggeri sat down on the right side of the kumis pitchers, ${ }^{2}$ Otčigin seized the collar of Teb Tenggeri, saying, 'Yesterday you compelled me to make amends. Let us now measure up to each other!' - and, holding his collar, dragged him towards the door. Teb Tenggeri, then, facing Otčigin, seized his collar and wrestled with him. As they were wrestling, Teb Tenggeri's hat fell in front of the fireplace. Father Mönglik took his hat, smelled it and placed it in his bosom. Činggis Qa'an said, 'Go out and match each other's strength and might.'

Otčigin dragged Teb Tenggeri out. The three strong men who had earlier been standing in readiness at the threshold of the door faced Teb Tenggeri. They seized

1 I.e., 'my sons.'

2 I.e., of the wine table. See above, $\$ 213$. 
him, dragged him out further, broke his back and cast him down at the end of the line of carts of the left side. ${ }^{1}$

Otčigin came back into the tent and said, 'Teb Tenggeri had compelled me to make amends. When I said, "Let us measure up to each other", he was not willing to wrestle and lay down pretending that he could not get up. Not much of a companion, is he!'

Father Mönglik understood and, shedding tears, said, 'I have been your companion

Since the brown earth

Was only the size of a clod,

Since the sea and rivers

Were only the size of a rivulet.'

At these words, his six Qongqotan sons barred the door and disposed themselves around the fireplace. When they rolled up their sleeves, Činggis Qa'an became frightened. Being pressed by them, he said, 'Make way, I am going out.' As soon as he stepped outside, quiverbearers and dayguards surrounded Činggis Qa'an and stood by.

Činggis Qa'an saw that after breaking his backbone, they $^{2}$ had cast Teb Tenggeri down at the end of the line of carts. He had a grey tent brought from the back and placed over Teb Tenggeri, saying, 'Fasten the harnessing to the carts, we shall move on.' And he moved on from there.

246 After they had covered the smoke-hole of the tent in which they had placed Teb Tenggeri, had blocked the door and put people to keep watch, on the third night at dusk Teb Tenggeri opened the smoke-hole of the tent and came out bodily through it. When they investigated closely, it was established that it really was Teb Tenggeri who had been seen in that part of the tent. ${ }^{3}$

Činggis Qa'an said, 'Because Teb Tenggeri laid hands on my younger brothers and spread baseless

1 I.e., the east side.

2 I.e., the three strong men.

3 I.e., over the smoke-hole. 
slanders among them ${ }^{1}$ in order to sow discord, he was no longer loved by Heaven, and his life, together with his body, has been taken away.'

Čnggis Qa'an then railed at Father Mönglik saying, 'By not restraining your sons' nature, you and your sons began thinking that you were equal to me, and you have paid for this with Teb Tenggeri's life. ${ }^{2}$ If I had known that you had such a nature, you would have been dealt with like Jamuqa, Altan, Qučar and the others.' So he railed at Father Mönglik.

When he had finished railing at him, he said further, 'If one retracts in the evening what one has said in the morning, and retracts in the morning what one has said the previous evening, surely one will only be criticised until he is covered with shame. I have earlier pledged my word to you. Enough of this matter!' And, his anger abated, he showed favour to him again. He said, 'Had you restrained your ambitious nature, who among Father Mönglik's offspring would have dared to consider himself equal to me?' After Teb Tenggeri had been annihilated, the proud air of the Qongqotan was much reduced.

1 Lit., 'among my younger brothers.'

2 Lit., 'head.' 


\title{
THE SECRET HISTORY OF THE MONGOLS
}

\author{
CHAPTER ELEVEN
}

(= SUP. 1)

247 After that, in the Year of the Sheep (1211), Činggis Qa'an set out against the Kitat people. He took Vujuiu, ${ }^{1}$ crossed over Hünegen Daba'an, took Söndiivu and sent J̌ebe and Güyigünek Ba'atur as vanguards.

On reaching Čabčiyal, seeing that the Čabčiyal Pass was defended, J̌ebe there and then said, 'We shall entice them and get them to move and come after us. Then, let us put them to the test!' So saying, he turned back. When they discovered that he had turned back, the Kitat troops said, 'Let us pursue him!', and they went in pursuit until the valleys and the mountains were completely covered with them. Upon reaching the spur of Söndiivu, J̌ebe turned back, rushed forth against the enemies who were approaching in successive waves and routed them. Čnggis Qa'an, pressing on with the main body of the army, dislodged the Kitat from their positions, crushed the valiant and bold Jüyin troops of the Qara Kidat and the Jürčet, slaying them until they were like heaps of rotten logs as far as Čabčiyal.

Jebe took the gate of Čabčiyal, and after he had captured the passes and crossed over them, Činggis Qa'an pitched camp at Šira Degtür.

Launching the attack on Jungdu, he sent troops to various towns and cities, ordering them to attack. He sent Jebe to attack the city of Dungčang. Jebe reached the city of Dungčang but, unable to take it by storm, turned back

${ }^{1}$ For the identification of the localities in north China mentioned in this and the following sections, see RSH 2.888-95. Most crucially, 'Vujiu' (Fu-chou) is the northernmost outpost of the Jurchen/Chin state (Kitat irgen, with a mixed population of Chinese and J̌ürčet); 'J̌ungdu' is Peking. 
and went as far as the distance of a six days' march from there. Then - the enemy being unaware - he returned and, marching throughout the night, each soldier leading a spare horse by hand, he arrived at the moment when the enemy was unprepared and took the city of Dungčang.

After taking the city of Dungčang, Jebe returned and joined Činggis Qa'an.

When Jungdu was under siege, a high official of the Altan Qan, Ongging Čingsang, advised the Altan Qan as follows: 'This is the destiny and favourable time decreed by Heaven and Earth. ${ }^{1}$ Could it be that the time has come when the great throne will pass to a new ruler? The Mongols are coming in great might: they have crushed our valiant and bold élite Jüiyin troops of the Qara Kitat ${ }^{2}$ and the Jürčet, slaying them until they were utterly destroyed. Even Čabčiyal Pass, on which we were relying, they have wrested from us. If we now set our troops in order and send them out to fight, should they again be crushed by the Mongols, they will no doubt scatter and return to their various cities. And, if we rally them against their will, they will turn against us and will no longer be our friends. If you, the Altan Qan, grant permission, let us for the present submit and come to terms with the ruler of the Mongols. If the Mongols agree to withdraw, after their withdrawal we shall there and then take up another different counsel. It is said that the men and geldings of the Mongols find our country unsuitable and fall victim to epidemics. Let us give a princess to their ruler, and to the men in his army let us send out gold, silver, satin and goods in abundance. Who knows whether they will or will not agree to our proposal?'

When Ongging Čingsang had given his advice, the Altan Qan approved these words of his, saying, 'Let it be so!' Then, offering submission, he sent to Cinggis Qa'an a

\footnotetext{
1 Cf. above, §194.

$2=$ Qara Kidat.
} 
princess by name of Gung ّ̌u ${ }^{1}$ and from J̌ungdu he sent out to the men in his army gold, silver, satin and goods - as much as, in their judgement, their strength and that of their horses could carry. He also sent Ongging Čingsang to Činggis Qa'an.

When they came and submitted themselves, Činggis Qa'an agreed to their proposal. He ordered back the troops that were attacking the various towns and withdrew. Ongging Čingsang accompanied Činggis Qa'an as far as the spurs called Mojiu ${ }^{2}$ and Vujuiu, and then returned. As for the satin and goods, our troops loaded as much as their horses could carry and moved away, tying up their loads with bands of heavy silk fabric.

249 In the course of that military campaign, Cinggis Qa'an set out towards the Qašin people. When, moving in their direction, he reached their country, Burqan Qan of the Qašin people said, 'I shall submit and, becoming your right ${ }^{3}$ wing, I shall serve you.' And he offered his daughter, called Čaqa, to Činggis Qa'an.

Further, Burqan Qan said, 'Hearing of Činggis Qa'an's fame we were in awe of you. Now your august person has arrived, you have come to us, and we are indeed awed by your majesty. Being awed, we the Tang'ut people have said, "We shall become your right ${ }^{3}$ wing and we shall serve you." When we serve you, know that

We are the ones who live in permanent camps,

We are the ones who have towns with pounded-earth walls.

And so, when we become your companions,

In waging a swift campaign,

In fighting a deadly combat,

We shall not be able to hasten into a swift campaign,

We shall not be able to fight a deadly combat.

1 This is not the name of the lady in question, but the Chinese term kung-chu meaning 'princess.'

${ }^{2}$ An error in the text, possibly for Mači. See RSH 2.900-02.

3 I.e., west. 
But if Činggis Qa'an shows favour to us, we the Tang'ut people,

We shall bring forth many camels

Reared in the shelter of the tall feather-grass:

We shall turn them into government property

And we shall give them to you.

We shall weave woollen material and make satin,

And we shall give them to you.

Training falcons to fly loose at game,

We shall gather them

and all the best ones we shall send to you.' Thus he petitioned Činggis Qa'an. And having spoken, he kept to his word. He levied camels from his Tang'ut people and, bringing so many that it was impossible to drive any more of them, he gave them to Činggis Qa'an.

250 On that campaign Čnggis Qa'an obtained the submission of the Altan Qa' an ${ }^{1}$ of the Kitat people and took a large quantity of satin. He also obtained the submission of Burqan of the Qašin people and took a great number of camels.

Having thus obtained the submission of the Altan Qan of the Kitat people, named Aqutai, and ${ }^{2}$ of Iluqu Burqan of the Tang'ut people in that campaign of the Year of the Sheep (1211), Činggis Qa'an returned home and set up camp on the Sa'ari Steppe.

251 Again, after that, since Jubqan and many other envoys of ours who were sent to Jau Gon to seek allegiance had been hindered by the Altan Qa'an ${ }^{1}$ Aqutai of the Kitat people, in the Year of the Dog (1214) Čnggis Qa'an set out once more against the Kitat people. On setting out he said, 'After they had already submitted themselves, how could they hinder the envoys sent to Jau Gon?'

Činggis Qa'an moved in the direction of the Tunggon Pass, ordering Jebe to go by way of Čabčiyal. Realizing that Činggis Qa'an had gone by the Tunggon Pass, the Altan Qan entrusted the command of his troops to Ile, Qada and Höbögetür, saying, 'With the army blocking the

1 Read Qan.

${ }^{2}$ Lit., 'and having obtained the submission.' 
passage and disposing the Red Coats as vanguard, fight for the Tunggon Pass and do not let them cross the defile!' And he sent Ile, Qada and Höbögetür in haste with the troops.

When Cinggis Qa'an arrived at the Tunggon Pass, the Kitat troops came to intercept him, saying, 'Our soil!' Činggis Qa'an fought against Ile, Qada and Höbögetür and put to flight Ile and Qada. Tolui and Čügü Gürigen ${ }^{2}$ then arrived and, charging at their flanks, forced back the Red Coats, repulsed and completely defeated Ile and Qada, and slew the Kitat until they were like heaps of rotten logs.

When the Altan Qan learned that his Kitat troops had been slain and destroyed, he fled out of Jungdu and entered the city of Namging. As the remnants of his troops were dying of starvation, they ate human flesh between them.

Because Tolui and Čügü Gürigen had performed well, Činggis Qa'an greatly favoured both of them. ${ }^{3}$

252 Čnggis Qa'an set up camp at Qosivu, then in the Šira Ke'er ${ }^{4}$ of J̌ungdu. J̌ebe broke down the gate of Čabčiyal and, having routed the enemy troops who were holding Čabčiyal, came and joined Činggis Qa'an.

When the Altan Qan moved out of Jungdu, he appointed Qada as Kiušiu in Jungdu before leaving the city. When Činggis Qa' an had the inventory taken of the gold, silver, goods, satin and other things gathered in Jungdu, he sent the steward Önggür, Arqai Qasar and Šigi Qutuqu to do it. As these three were approaching, Qada went ahead to greet them, taking with him goldembroidered and patterned satins. He came out of Jungdu and welcomed them.

${ }^{1}$ I.e., 'Let us defend our soil!'

2 The Čigü Güregen of $\$ 202$ (no. 85).

${ }^{3}$ Lit., 'both Tolui and Čügü Gürigen.'

4 I.e., 'the Yellow Plain', i.e. the open country north of Peking, 'yellow' no doubt referring to the characteristic colour of the soil (loess). See RSH 2.916.

${ }^{5}$ I.e., as temporary vicegerent or governor. 
Šigi Qutuqu said to Qada, 'Formerly, the goods of this Jungdu, and the very city of J̌ungdu, did belong to the Altan Qan. Now J̌ungdu surely belongs to Činggis Qa'an. How can you give us the goods and satins of Činggis Qa'an, stealing them and bringing them here behind his back? I shall not take them.' Thus spoke Šigi Qutuqu and did not take them, but the steward Önggür and Arqai took them. After making the inventory of the goods and other things of Jungdu, these three came back to Cinggis Qa'an.

Činggis Qa'an then asked Önggür, Arqai and Qutuqu, 'What did Qada give you?' Šigi Qutuqu said, 'He brought and gave us gold-embroidered and patterned satins. I said to him, "Formerly, this Jungdu belonged to the Altan Qan. Now it has surely become Činggis Qa'an's property. How can you, Qada, give us Činggis Qa'an's goods, stealing them behind his back?" Thus I said and did not take them, but Önggür and Arqai took what Qada had given them.' So spoke Šigi Qutuqu.

Činggis Qa'an then mightily rebuked Önggür and Arqai. As for Šigi Qutuqu, he greatly favoured him, saying, 'You, Šigi Qutuqu, have been mindful of the great norm concerning one's obligations to the qan. ${ }^{1}$ And he said, 'You shall be

Eyes for me to see with,

Ears for me to hear with! ${ }^{2}$

253 After the Altan Qan had entered Namging, he submitted himself in person and, making obeisance, sent his son called Tenggeri, with a hundred companions, to Činggis Qa'an to serve as a dayguard and hostage.

As the Altan Qan had been brought under submission by him, Činggis Qa'an said that he would withdraw. There and then he withdrew by the Čabčiyal Pass, sending Qasar along the sea coast with the troops of the left ${ }^{3}$ wing. He sent him with the following instructions: 'Set

1 Cf. above, $\$ 220$.

2 See above, $\S \S 138$ and 203.

3 I.e., east. 
up camp at the city of Beiging. ${ }^{1}$ After you have subjugated the city of Beiging, proceed further and cross the country of Vuqanu of the Jürčet. If Vuqanu intends to offer resistance, go for him. If he submits, pass through their ${ }^{2}$ border towns, go along the rivers Ula and $\mathrm{Na}$ 'u, and crossing the Ta'ur River upstream, join forces with me at the main basecamp.' With Qasar he sent Jürčedei, Alči and Tolun Čerbi from among the army commanders.

Qasar brought the city of Beiging into subjection, forced Vuqanu of the Jürčet to submit and subjugated the towns which were on the way there. Qasar then proceeded upstream along the Ta'ur River and settled at the main base camp.

254 After that, as Činggis Qa'an's one hundred envoys with Uquna at their head had been held up and slain by the Sarta'ul people, Činggis Qa'an said, 'How can my “golden halter" be broken ${ }^{3}$ by the Sarta'ul people?' And he said, 'I shall set out against the Sarta'ul people,

To take revenge,

To requite the wrong

for the slaying of my hundred envoys with Uquna at their head.'

When he was about to set out, there and then Yisüi Qatun respectfully gave the following advice to Činggis Qa'an: 'The Qa'an has thought of

Establishing order over his many people,

Climbing high passes,

Crossing wide rivers

And waging a long campaign.

Still, living beings who are but born to this world are not eternal:

When your body, like a great old tree,

Will fall down,

To whom will you bequeath your people

1 Buiging? See RSH 2.921.

2 I.e., the Jürčet's.

3 I.e., 'How can my sovereign authority be infringed?' The 'golden halter' refers to the firm bond uniting the Mongol qan to other rulers who owed him allegiance. 
Which is like tangled hemp?

When your body, like the stone base of a pillar,

Will collapse,

To whom will you bequeath your people

Which is like a flock of birds? ${ }^{1}$

Of your four sons, the heroes whom you have begotten, which one will you designate as your successor? I have given you this advice on what, thinking about it, we - the sons, younger brothers, the many common people and my poor self ${ }^{2}$ - understood to be an important question. Your order ${ }^{3}$ shall decide!'

So she advised him and Činggis Qa'an declared: 'Even though she is only a woman, ${ }^{4}$ Yisüi's words are more right than right. No matter who - younger brothers and sons, and you Bo'orču, Muqali and others - no one has advised me like this. And also

I forgot,

As if I would not follow the forefathers;

I slept,

As if I would not be caught by death.'

Having said this, he said, 'The eldest of my sons is J̌oči. What do you, J̌či , say? Speak up!' But before J̌oči could utter a sound, Ča'adai said, 'When you say, "J̌oči, speak up!", do you mean by that that you will appoint Joči as your successor? How can we let ourselves be ruled by this bastard offspring of the Merkit? ${ }^{5}$

At these words, J̌oči rose and grabbing Ča' adai by the collar, said, 'I have never been told by $m y$ father the Qan that I was different from my brothers. How can you discriminate against me? In what skill are you better than I? Only in your obstinacy you are, perhaps, better. If we shoot arrows at a long distance and I am outdone by you, I shall cut off my thumb and throw it away! If we wrestle

${ }^{1}$ Cf. above, $\$ 245$.

${ }^{2}$ Lit., 'and Us "the bad one."

${ }^{3}$ I.e., 'word.'

${ }^{4}$ Lit., 'a lady-person.'

${ }^{5}$ For the implications of Ča'adai's insulting words, see RSH 2.92627. 
and I am defeated by you, I shall not rise from the place where I have fallen! Let the order ${ }^{1}$ of $m y$ father the Qan decide which of us is better!'

So he said, and as J̌oči and Ča'adai both stood holding each other by the collar, with Bo'orču pulling J̌či by the arm and Muqali pulling Ča'adai by the arm, Činggis Qa'an listened and sat without saying a word.

Then, Kökö Čos, who was standing on the left side, said, 'Ča'adai, why are you so hasty? It was you, among the sons, for whom your father the Qan had cherished hopes. Before you were born,

The starry sky was turning upon itself,

The many people were in turmoil:

They did not enter their beds to rest,

But fought against each other.

The crusty earth was turning and turning,

The entire nation was in turmoil:

They ${ }^{2}$ did not lie on their coverlets to rest,

But attacked each other.

At such time your mother was abducted.

It was not her wish:

It happened at a time

When men met, weapons in hand.

She was not running away from her home:

It happened at a time

Of mutual fighting.

She was not in love with someone else:

It happened at a time

When one man slew another.

You speak so as to harden the butter of your mother's affection, so as to sour the milk of that august lady's heart. $^{3}$

From the warm womb, coming forth

Suddenly, were you two

Not born from the same belly?

1 I.e., 'word.'

2 I.e., the people.

3 'Butter' and 'milk' indicate softness and loving kindness respectively. 
From the hot womb, coming forth

Abruptly, were you two

Not issued from a single womb?

If you incur blame

From your mother who has borne you

From her heart, her affection

For you will grow cold:

Even if you appease her

It will be of no avail.

If you incur reproach

From your mother who has borne you

From her belly,

Even if you lessen her reproach

It will be of no avail.

When your father the Qan

Established the whole nation,

His black head was bound to the saddle,

His black blood was poured

Into a large leather bucket. ${ }^{1}$

His black eyes he did not wink,

His flat ear he did not rest on a pillow:

Of his sleeve he made a pillow and

He spread his robe for a mattress.

Easing his thirst with his own saliva,

Eating the flesh between his teeth for supper, he strove fiercely, and

Till the sweat of his brow reached the soles of his feet,

Till the sweat from the soles of his feet went up to his brow,

he applied himself earnestly to his great task. It was the time when your mother, together with him, suffered hardship:

Pulling firmly her tall hat

Over her head,

Tying tightly her belt

To shorten her skirt,

Fastening her tall hat

${ }^{1}$ I.e., he was in constant danger of losing his life. For these images see RSH 2.928-29. 
Over her head,

Fixing her belt

To tighten her waist,

She brought you up, her sons. ${ }^{1}$

As she gulped her food

She gave you half of it;

Her throat choking with pity

She gave you all of it,

And she herself went hungry.

Stretching your shoulders,

"How shall I make them into men?"

She said to herself.

Stretching your necks,

"How shall I make them into adults?"2

She said to herself.

Cleaning your whole body,

Causing you to lift your heels

And learn how to walk,

She made you reach

Up to men's shoulders,

Up to geldings' cruppers.

And even now, does she not wish to see the happiness of you, her sons? Our august Qatun, in bringing you up had a heart

As bright as the sun,

As wide as a lake.'

So he spoke.

255 Thereupon, Činggis Qan said to Ča'adai, 'How can you speak thus about Joči? Isn't J̌oči the eldest of my sons? In future do not talk like that!' So he said, and at these words Ča'adai smiled and said, 'I shall not dispute Joči's strength, nor shall I reply to his claims of skill:

"Game that one has killed only with one's mouth

Cannot be loaded on one's mount;

Game that one has slain only with one's words

Cannot be skinned."

1 Cf. above, $\$ 74$.

${ }^{2}$ Cf. above, $\$ 214$. 
The eldest sons are J̌oči and I. ${ }^{1}$ We shall, in cooperation with each other, serve our father the Qan.

Whichever of us ${ }^{2}$ evades his duty

Shall have his head split open;

Whichever of us lags behind

Shall have his heels cut across.

But it is Ögödei among us who is steady and reliable: let us, therefore, agree on Ögödei. As Ögödei is close to our father the Qan, if the Qan instructs him on the great array of the "teachings of the hat", 3 this will be fine!'

So he spoke, and at these words Činggis Qa'an said, 'What do you say, J̌oči? Speak up!' Whereupon, J̌oči said, 'Ča' adai has just said it: Ča'adai and $\mathrm{I}^{4}$ shall, in cooperation with each other, serve the Qan. Let us agree on Ögödei.' So he spoke, and Činggis Qa'an declared as follows: 'Why should you two go so far as to cooperate with each other? Mother Earth is wide: its rivers and waters are many. Extending the camps ${ }^{5}$ that can be easily divided, We shall make each of you rule over a domain and We shall separate you.' And he said, 'You Joči and Ča'adai, keep to your word:

Do not let yourselves be scorned by people,

Do not let yourselves be laughed at by men.

Formerly, Altan and Qučar had pledged their word like that, ${ }^{6}$ but because they failed to keep their word, how were they dealt with? What happened to them? Now, with you, We shall separate also some of the offspring of Altan and Qučar: seeing them, how can you be remiss in your duties?'

Having spoken thus, Činggis Qa'an said, 'Ögödei, what do you say? Speak up!' Ögödei said, 'When my father the Qa'an, favouring me, tells me to speak, what am I to say? How can I say that I am not able to do so? I

Lit., 'we.'

2 Lit., 'The one of us who.'

3 I.e., on how to be a qan. See RSH 2.932-33.

${ }^{4}$ Lit., 'we.'

${ }^{5}$ I.e., the grazing grounds.

${ }^{6}$ I.e., 'as you did.' 
shall say that I will certainly try according to $m y$ ability. Later, if perchance some among my descendants will be born so worthless that

Even if one wrapped them in fresh grass,

They would not be eaten by an ox;

Even if one wrapped them in fat,

They would not be eaten by a dog, will they not "miss the elk breadthwise just as the rat lengthwise?"1 I'll say as much as that. What else shall I say?'

So he spoke, and at these words Činggis Qa'an declared as follows: 'If Ögödei speaks such words, that will do.' Further, he said, 'Tolui, what do you say? Speak up!'

Tolui said, 'Being at the side of my elder brother ${ }^{2}$ whom our father the Qa'an has just designated,

I shall remind him of what he has forgotten,

I shall wake him up when he has fallen asleep.

I shall become a friend of the word "yes"

And the whip of his chestnut horse.

Not being remiss in $m y$ "yes",

Not being absent from the ranks,

I shall go forth for him on a long campaign

Or fight in a short fight.'

When Tolui had spoken thus, Činggis Qa'an approved, saying, 'Descendants of Qasar, appoint one of you to govern. Descendants of Alčidai, appoint one of you to govern. Descendants of Otčigin, appoint one of you to govern. Descendants of Belgütei, appoint one of you to govern. If, thinking in this way and appointing one of my descendants to govern, you do not rescind my order by contravening it, then you will not err, you will not be at fault. Supposing that the descendants of Ögödei are all born so worthless that

Even if one wrapped them in fresh grass,

${ }^{1}$ I.e., just like an unskilled hunter; in other words, they will be totally unfit to govern.

2 I.e., Ögödei. 
They would not be eaten by an ox;

Even if one wrapped them in fat,

They would not be eaten by a dog, is it possible that among my descendants not even a single one will be born who is good?' So he spoke.

256 When Činggis Qa'an set out on the campaign, he sent envoys to Burqan of the Tang'ut people with a message saying: 'You said that you would be $m y$ right ${ }^{1}$ wing. As the Sarta'ul people have broken my "golden halter", ${ }^{2}$ I have set out to call them to account for their action. You set forth too as the right wing of my army.'

When the message he had sent was received, and before Burqan could utter a word, Aša Gambu forestalling him said, 'Since Činggis Qa'an's forces are incapable of subjugating others, ${ }^{3}$ why did he go as far as becoming qan?' So saying, he did not dispatch auxiliary troops to him and sent back the envoys with haughty words.

Thereupon, Činggis Qa'an said, 'How can we bear being spoken to in this manner by Aša Gambu?' And he said, 'The best plan would be for us to send troops against them at once by detouring in their direction. What difficulty would there be in that? But now, when we are indeed moving in the direction of other people, let that pass. If I am protected by Eternal Heaven, when I come back pulling in strongly $m y$ golden reins, ${ }^{4}$ then surely this matter shall be dealt with!'

257 In the Year of the Hare (1219), Činggis Qa'an set out against the Sarta'ul people crossing the Alai. ${ }^{5}$ From among the ladies, he took with him on the campaign Qulan Qatun and, having entrusted Otčigin Noyan from among his younger brothers with the main base camp, he moved forth. He sent Jebe as vanguard. He sent Sübe'etei in support of J̌ebe and sent Toqučar in support of Sübe'etei.

1 I.e., west.

2 See above, $\$ 254$.

3 I.e., on their own, without assistance.

4 I.e., at the end of the campaign. Cf. below, $\$ 275$.

5 Arai in the text. Cf. above, $\S 198$. 
As he sent these three ahead he said, 'Go round the outside, coming out at the other side ${ }^{1}$ of the Sultan ${ }^{2}$ and, waiting for Us to arrive, attack him from your side.' So saying he sent them forth.

Jebe then went and, passing the cities of Qan Melik without touching them, he bypassed them on the outside. Behind him, Sübe'etei bypassed them in the same manner without touching them. But Toqučar, coming behind him, ${ }^{3}$ attacked the border towns of Qan Melik and pillaged his peasants. Because his towns had been attacked, Qan Melik rose in rebellion against us and joined J̌alaldin Soltan.

J̌alaldin Soltan and Qan Melik moved against Činggis Qa'an. Šigi Qutuqu went as vanguard before Činggis Qa'an. J̌alaldin Soltan and Qan Melik fought with Šigi Qutuqu. They defeated Šigi Qutuqu and, pressing on, approached as far as Činggis Qa'an; at that moment, however, J̌ebe, Sübe'etei and Toqučar came in from behind Jalaldin Soltan and Qan Melik, overcame them and utterly destroyed them. By so doing, ${ }^{4}$ they prevented them from joining forces in the cities of Buqar, Semisgab ${ }^{5}$ and Udarar. ${ }^{6}$ They pursued them as far as the Šin River and when, being pressed, the Sarta'ul started throwing themselves into it, ${ }^{7}$ many of them did indeed perish there, in the Šin River. Jaalaldin Soltan and Qan Melik fled upstream along it, ${ }^{8}$ saving their lives.

Činggis Qa'an advanced along the Šin River upstream and went to plunder Batkesen. He reached the Eke Stream and the Ge'ün Stream, and set up camp in the Baru'an

${ }^{1}$ I.e., at the back.

$2=$ Soltan, i.e. Jalaldin Soltan mentioned below.

${ }^{3}$ I.e., Sübe'etei.

${ }^{4}$ Lit., 'Overcoming them.'

5 An error for Semisgen.

${ }^{6}=$ Bukhara, Samarkand, and Otrar; for the identification of the localities in this and the following sections, see RSH 2.943. Sin $(<$ Šind $)$ is the Indus River.

${ }^{7}$ Lit., 'into the Šin River.'

${ }^{8}$ Lit., 'along the Šin River.' 
Plain. He sent Bala of the Jalayir ${ }^{1}$ in pursuit of Jalaldin Soltan.

Činggis Qa'an, greatly favouring J̌ebe and Sübe'etei, said, 'J̌ebe, you were named J̌irqo'adai. When you came to $m e$ from the Tayiči'ut, you indeed became ${ }^{2}$ Jebe. Toqučar, of his own will, attacked the border towns of Qan Melik and caused him $^{3}$ to rebel against us. Making this a matter of law, we shall execute him!' However, in the end he did not execute him, but having severely reprimanded him, he punished him by demoting him from his command of the army.

258 Then Činggis Qa'an, returning from the Baru'an ${ }^{4}$ Plain, sent his three sons, J̌oči, Ča'adai and Ögödei, saying, 'Cross the Amui River with the troops of the right ${ }^{5}$ wing and set up camp at the city of Ürünggeči.' He sent Tolui, saying, 'Set up camp at Iru, Isebür and many other towns.' Činggis Qa'an himself encamped at the city of Udirar. ${ }^{6}$

The three sons, Joči, Ča'adai and Ögödei sent the following request: 'Our troops are completely assembled. We have reached the city of Ürünggeči. Of the three of us, according to whose words should we act?' Upon their request, Čnggis Qa'an sent a message to them ordering that they should act according to the words of Ögödei.

259 Then Činggis Qa'an, having brought the city of Udurar $^{7}$ to submission, set out from the city of Udurar and pitched camp at the city of Semisgab. ${ }^{8}$ Setting out from the city of Semisgab, he pitched camp at the city of Buqar. Thereupon, Činggis Qa'an waited for Bala and spent the summer at the ridge of Altan Qorqan in the

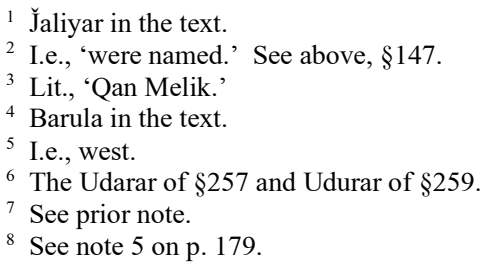

${ }^{8}$ See note 5 on p. 179. 
former summer quarters of the Soltan. ${ }^{1}$ From there he sent messengers to Tolui, saying, "The weather ${ }^{2}$ has become warm. The other troops must set up camp too. You come and join Us.'

When he sent this message, Tolui had captured the cities of Iru, Isebür and others, had destroyed the city of Sisten and was just destroying the city of Čuqčeren. When the messengers gave him this message, Tolui, having destroyed the city of Čuqčeren, returned to pitch camp and joined Činggis Qa'an.

260 Joči, Ča'adai and Ögödei, these three sons of Činggis $Q a^{\prime}$ 'an, subjugated the city of Örünggeči: ${ }^{3}$ they shared the people of the cities among all three of them but did not give Činggis Qa'an a share.

When these three sons came to set up camp, Činggis Qa'an reprimanded J̌oči, Ča'adai and Ögödei - the three sons in question - and for three days did not allow them into his presence. Then Bo'orču, Muqali and Šigi Quduqu ${ }^{4}$ petitioned as follows: 'We caused the Soltan of the Sarta'ul people, who had refused to submit, to abase himself and we conquered his cities and peoples. The city of Örünggeči, ${ }^{3}$ which was taken and shared, and the sons of yours who took it and shared it among themselves, all belong to Činggis Qa'an. Now that, with our strength increased by Heaven and Earth, we have caused the Sarta'ul people to abase themselves like this, we - the men of your entire army - are rejoicing and are content with ourselves. Why is the Qa'an so angry? The sons have realized their mistake and are indeed afraid. Let this be a lesson for their future conduct! We fear lest the sons' natural ardour may be discouraged as a result of this. Will you not, therefore, show favour to them again and allow them into your presence?'

Upon their petition, Čnggis Qa'an, appeased, allowed the three sons Joči, Ča'adai and Ögödei into his presence.

1 = Sultan. Here Muḥammad Šāh is almost certainly meant.

${ }^{2}$ Lit., 'the year.'

$3=$ Ürünggeči.

${ }^{4}=$ Qutuqu. See above, $§ 135$. 
He rebuked them

Quoting ancient words,

Citing old sayings,

and reprimanded them

To the point where they almost sank

In the place where they stood,

To the point where they could not wipe off

The sweat of their brow. ${ }^{1}$

Just as he was addressing them with reprimands and admonitions, Qongqai Qorči, Qongtaqar Qorči and Čormaqan Qorči - these three quiverbearers - also petitioned Činggis Qa'an as follows: 'Like grey falcons that have just begun training, the sons are barely learning how to wage a military campaign, and, at such a time, you rebuke them in this way, piling abuse on them. ${ }^{2}$ Why? We fear lest the sons, being afraid, will lose heart. From the place where the sun sets to the place where it rises there are enemy people. If you incite us - your Tibetan dogs - and send us on a mission, with our strength increased by Heaven and Earth we shall bring back for you enemy people, gold, silver, satin, goods and subjects. If you say, "Which people?", we say, "Here in the west there is one called the Qalibai Soltan of the Baqtat people." Let us move against him!' So they petitioned him. The Qa'an was appeased by these words and his anger abated.

Činggis Qa'an approved their proposal and issued the following order, favouring the three quiverbearers Qongqai, Qongtaqar and Čormaqan: 'Qongqai of the Adargin and Qongtaqar of the Dolonggir shall stay at my side.' $\mathrm{He}$ sent Čormaqan of the Ötegen on a campaign against the Baqtat people and the Qalibai Soltan.

261 Further, Čnggis Qa'an sent Dörbei Doqšin of the Dörbet on a campaign against Aru, ${ }^{3}$ Maru and the city of Abtu of the Madasari people between the Hindus people and the Baqtat people.

1 Because they were sweating so profusely.

2 Lit., '(on) the sons.'

3 An error for Iru. Cf. above, $\S \S 258,259$. 
262 Further, he sent Sübe'etei Ba'atur northwards to campaign as far as the countries and peoples of these eleven tribes: Qanglin, Kibča'ut, Baǰigit, Orusut, Maǰarat, Asut, Sasut, Serkesüt, Kešimir, Bolar and Kerel; ${ }^{1}$ and, making him cross the rivers Idil and Jayaq rich in waters, he sent Sübe'etei Ba'atur to campaign as far as the city of Kiwa Menkermen.

263 Further, having completed the conquest of the Sarta'ul people, Činggis Qa'an issued an order setting up resident commissioners ${ }^{2}$ in the various cities. Two Sarta'ul of the Qurumši clan - father and son - called Yalawači and Masqut, came from the city of Ürünggeči. They told Činggis Qa'an about the laws and customs of cities; whereupon the latter, being adequately informed as to these customs, appointed his ${ }^{3}$ son Masqut the Qurumši, putting him in charge, with our resident commissioners, of Buqar, Semisgen, Ürünggeči, Udan, Kisqar, Uriyang, Güsen Daril and other cities. $\mathrm{He}^{4}$ brought back with him his ${ }^{5}$ father Yalawači and put him in charge of the city of Jungdu of the Kitat.

Because, from among the Sartaq ${ }^{6}$ people, Yalawači and Masqut were adept in the laws and customs of cities, Činggis Qa'an appointed them, with our resident commissioners, putting them in charge of the Kitat people.

264 Ćinggis Qa'an spent seven years in the country of the Sarta'ul people. Then, at the time when he was waiting for Bala of the Jalayir, Bala, having crossed the Šin River, was pursuing J̌alaldin Soltan and Qan Melik as far as the country of the Hindus. He lost track of Jalaldin Soltan and Qan Melik and, even though he sought them as far as the middle of the country of the Hindus, he was unable to find them and returned. He came back pillaging the

${ }^{1}$ The text has incorrectly Raral. For all these names see RSH 2.959-

61. See also the Names Index below.

${ }^{2}$ Daruqačin and, further down, daruqa. See RSH 2.961-62.

3 I.e., Yalawači's.

${ }^{4}$ I.e., Činggis Qa'an.

5 I.e., Masqut's.

${ }^{6}=$ Sarta'ul. 
people on the border of the Hindus and seizing many camels and many gelded billy-goats.

Then Činggis Qa'an returned home. On the way he spent the summer on the river Erdiš. In the autumn ${ }^{1}$ of the Year of the Hen (1225) - the seventh year of the campaign - he settled at his Palaces ${ }^{2}$ in the Black Forest by the Tūla. ${ }^{3}$

${ }^{1}$ Read 'spring' (qabur) for 'autumn' (namur).

${ }^{2}$ Ordos, i.e. the royal encampment.

3 = the Tu'ula of $\S \S 96,104,115,164,177$ and 178 above. 


\title{
THE SECRET HISTORY OF THE MONGOLS
}

\author{
CHAPTER TWELVE
}

(= SUP. 2)

265 After spending the winter there, ${ }^{1}$ Činggis Qa'an said, 'I shall set forth against the Tang'ut people.' He counted his troops anew and in the autumn of the Year of the Dog (1226) set forth against the Tang'ut people. From among the ladies, he took with him Yisüi Qatun.

In the winter, Činggis Qa'an, riding his steed Josotu Boro, ${ }^{2}$ on the way hunted the many wild asses of Arbuqa. When the wild asses passed close by them Josotu Boro took fright. Činggis Qa'an fell off the horse and, his body being in great pain, he halted at Čo'orqat.

He spent that night there and the following morning Yisüi Qatun said, 'Princes and commanders, consult each other on what to do: the Qa'an has spent the night, his body hot with fever.' Thereupon, the princes and commanders assembled and Tolun Čerbi of the Qongqotan advised as follows: 'The Tang'ut people

Are ones who have towns with pounded-earth walls, Are ones who live in permanent camps.

They won't leave, carrying off their towns with pounded-earth walls;

They won't leave, abandoning their permanent camps. $^{3}$

Let us withdraw. Then, when the Qa'an's body has cooled down, we shall set out again!'

When he spoke thus, all the princes and commanders agreed with his words and petitioned Činggis Qa'an accordingly, but Činggis Qa'an said, 'The Tang'ut people

${ }^{1}$ I.e., at his ordos in the Black Forest by the Tūla. See above, §264.

2 I.e., 'Reddish Grey.'

${ }^{3}$ See above, $\$ 249$. 
will say that we turned back because we lost heart. However, if we send envoys to them and watch right here at Čo'orqat which turn my illness takes, ${ }^{1}$ and withdraw after considering their reply, ${ }^{2}$ that would be fine.' And so he sent envoys to carry the following message: 'In the past, you, Burqan, said, "We, the Tang'ut people, shall be your right ${ }^{3}$ wing." 4 Although told so by you, when I sent you a request for troops, saying that I was going on a campaign because the Sarta'ul people had not agreed to my proposal, you, Burqan, did not keep your promise and did not give me troops, but came out with mocking words. ${ }^{5}$ As I was moving in a different direction at the time, I said that I would call you to account later. I set out against the Sarta'ul people and being protected by Eternal Heaven I brought them duly under submission. ${ }^{6}$ Now I have come to call Burqan to account for his words.'

Burqan said, 'I did not speak the mocking words.' Thereupon Aša Gambu said, 'I spoke the mocking words. As for now, if you Mongols, who are used to fighting, say, "Let us fight!", then turn towards the Alašai and come to me, for I have an encampment in the Alašai,

I have tents of thin woollen cloth,

I have camels laden with goods.

Let us fight there! If you need gold, silver, satin and other goods, turn towards Eriqaya and Eriǰe'ü.' He sent this message to Činggis Qa'an.

When his words were conveyed to Činggis Qa'an, his body was still hot with fever. Činggis Qa' an said, 'This is enough! When one lets oneself be addressed so boastfully, how can one withdraw? Even if we die let us challenge their boasts!' And, saying, 'Eternal Heaven, you be the judge!', he moved in the direction of Alašai.

$\mathrm{He}$ arrived there and fought with Aša Gambu. He

1 Lit., 'trying the illness.'

2 Lit., 'their (i.e. the Tang'ut's) word.'

3 I.e., west.

4 See above, $\S \S 249$ and 256.

5 A reference to Aša Gambu's words in $\$ 256$ above.

${ }^{6}$ Lit., 'I forced them into righteousness.' 
overcame Aša Gambu and forced him to barricade himself up on the Alašai. He captured Aša Gambu and plundered his people

Who had tents of thin woollen cloth,

Who had camels laden with goods, until they were blown to the winds like hearth-ashes.

He then gave the following order: 'Kill the valiant, the bold, the manly and the fine Tang'uts, and let the soldiers take for themselves as many of the common Tang' ${ }^{1}{ }^{1}$ as they can lay hands on and capture.'

266 Činggis Qa'an spent the summer on Časutu ${ }^{2}$ Mounain. He sent troops against the Tang'uts

Who had tents of thin woollen cloth,

Who had camels laden with goods,

and who, with Aša Gambu, had made for the mountains and were offering resistance. He caused his troops to plunder them as planned until they were utterly destroyed.

Then, showing favour to Bo'orču and Muqali, he ordered that they should take as much booty as in their judgement their strength could carry.

Further, Činggis Qa'an ordered to reward Bo'orču and Muqali as follows: 'Since I did not give you a share of the Kitat people, the two of you take and divide equally between yourselves the Jüyin of the Kitat people. Go and make their fine sons follow you, holding your falcons. Bring up their fine daughters and make them arrange the hems of your wives' skirts. The trusted friends of the Altan Qan of the Kitat people are the Qara Kitat Jüyin people who have destroyed the ancestors of the Mongols. Now, you two, Bo'orču and Muqali, are my trusted friends.'

267 Činggis Qa'an moved away from Časutu Mountain and set up camp at the city of Uraqai. After setting out from the city of Uraqai, while he was destroying the city of Dörmegei, Burqan came to pay homage to Činggis Qa'an.

1 I.e., of the Tang'ut population at large.

2 I.e., 'Snowy.' 
Burqan then paid homage, presenting himself with gifts such as, in the first place, golden images of Buddha; then golden and silver bowls and vessels, nine of each kind; boys and girls, nine of each; geldings and camels, nine of each; and all sorts of other objects arranged in nines according to their colour and form. Cinggis Qa'an kept the door closed and made Burqan pay homage outside the tent.

On that occasion, when Burqan paid homage, Činggis Qa'an felt revulsion within his heart. On the third day, Čnggis Qa'an issued an order giving Iluqu Burqan the name Šidurqu. ${ }^{1}$ Being thus visited by Iluqu Burqan Šidurqu, Činggis Qa'an then ordered that Iluqu be put to death and that Tolun Čerbi seize and execute him with his own hands.

Afterwards, when Tolun Čerbi reported that he had seized Iluqu and killed him, Činggis Qa'an ordered as follows: 'When I approached the Tang'ut people to call Iluqu Burqan to account for his words, and on the way hunted the wild asses of Arbuqa, my body being in pain, it was indeed Tolun who, concerned about my life, spoke words of advice and said, "Let it heal!" 2 We came here on account of the poisonous words of an enemy and with Our strength increased by Eternal Heaven, who gave him into Our hands, we took Our revenge. Tolun shall take for himself this movable palace brought by Iluqu, together with the bowls and vessels.' So he ordered.

268 After he had plundered the Tang'ut people and, making Iluqu Burqan change his name to Šidurqu, had done away with him, and after having exterminated the Tang'ut people's mothers and fathers down to the offspring of their offspring, maiming and taming ${ }^{3}$ (?), Cinggis Qa'an gave the following order: 'While I take my meals you must talk about the killing and destruction of the Tang'ut and say, "Maimed and tamed, they are no more."

'I.e., 'Upright.' See RSH 2.976-77.

${ }^{2}$ See above, $\$ 265$.

${ }^{3}$ Muquli musquli. See RSH 2.977-79. 
Because the Tang'ut people gave their word but did not keep it, ${ }^{1}$ Čnggis Qa'an for the second time took the field against them. ${ }^{2}$ Having destroyed the Tang'ut people, Čnggis Qa'an came back and in the Year of the Pig (1227) ascended to Heaven. After he had ascended to Heaven a great part of the Tang'ut people was given to Yisüi Qatun.

269 In the Year of the Rat (1228), the princes of the right hand $^{3}$ headed by Ča'adai and Batu; the princes of the left hand $^{4}$ headed by Otčigin Noyan, Yegü and Yisüngge $;^{5}$ the princes of the centre headed by Tolui; the princesses, the imperial sons-in-law, the commanders of ten thousand and those of a thousand, all assembled in full force at Köde'ü Aral on the Kelüren River. In accordance with the very decree by which Čnggis Qa'an had nominated him they installed Ögödei Qa'an as qan.

Elder brother Ča'adai installed his younger brother Ögödei Qa'an as qan. The nightguards, the quiverbearers and the eight thousand dayguards who had been protecting the precious life of their father Činggis Qa'an, the personal slaves and the ten thousand guards who had been in close attendance on the person of $\mathrm{my}^{6}$ father the Qan were all handed over by elder brother Ča'adai and Tolui to Ögödei Qa'an. The domain of the centre they handed over to him in the same manner.

270 Ögödei Qa'an, having concluded the installation of himself as qan and the transfer of the ten thousand guards on internal duty together with the domain of the centre to himself, held first of all a consultation with elder brother Ča'adai, whereupon he sent Oqotur and Mönggetü on a campaign in support of Čormaqan Qorči who had taken the field against the Qalibai Soltan of the Baqtat people a people not dealt with by his father Činggis Qa'an.

1 Lit., 'did not keep to the word.'

2 Lit., 'against the Tang'ut people.'

3 I.e., of the west.

4 I.e., of the east.

5 Written Yisünge. See $\$ 183$ and RSH 2.659.

6 A mistake for 'his'? See RSH 2.987-88. 
Earlier on, Sübe'etei Ba'atur, campaigning against Meket, Menkermen Keyibe and other cities, had crossed the rivers Adil ${ }^{1}$ and J̌ayaq rich in waters, and had reached as far as the Qanglin, Kibča'ut, Baj̆igit, Orusut, Asut, Sesüt, Maǰar, Kešimir, Sergesüt, Buqar and Kerel peoples. $^{2}$

As Sübe'etei Ba'atur had been put in a difficult situation by these peoples, Ögödei Qa'an sent forth Batu, Büri, Güyük, Möngge and several other princes in support of Sübe'etei. He ordered that Batu should be in command of all those princes who went on the campaign and that ${ }^{3}$ Güyük should be in command of all the troops coming from the centre. ${ }^{4}$ He further ordered, with regard to those who went on the campaign, that the princes in charge of a domain should send the eldest of their sons into the field and that the princes who were not in charge of a domain, the commanders of ten thousand, of a thousand, of a hundred and of ten, and any commoners, whoever they might be, should also send the eldest of their sons into the field. Likewise, the princesses and imperial sons-in-law should send the eldest of their sons into the field.

Further, Ögödei Qa'an said, 'This principle of sending the eldest sons on a campaign does indeed originate from elder brother Ča'adai. Elder brother C̆a'adai came and said to me, "I shall send Büri, the eldest of my sons, on the campaign in support of Sübe'etei. If the eldest of the sons goes into the field, the army will be larger than before. If the troops who set forth are numerous, they shall go to fight looking superior and mighty. The enemy people beyond consist of many states, and there, at the end of the world, they are hard people. They are people who, when they become angry, would rather die by their own swords. I am told they have sharp swords." So he said when he came.' Then Ögödei Qa'an

1 The Idil of $\$ 262$ and Ejil of $\$ 274$, i.e. the Volga.

2 For all these names, which already appear in $\$ 262$ above, see RSH 2.990-91.

3 Lit., 'and ordered that.'

${ }^{4}$ I.e., those belonging to the main body of the army. 
said, 'By these words and by the zeal and strength of Our elder brother Ča'adai, let us send out the eldest of the sons.' And he proclaimed this order everywhere. Such is the way in which he sent Batu, Büri, Güyük, Möngge and the other princes into the field.

271 Further, Ögödei Qa'an sent the following message to elder brother Ca' adai asking for advice: 'I have sat on the throne made ready by my father Činggis Qa'an. Will people not say of me, "By what merit has he sat on it?" If elder brother Ča'adai agrees, since our father the Qa'an did leave matters with the Altan Qan of the Kitat people unfinished, I shall now move against the Kitat people.' So he sent this message asking for advice.

Elder brother C̆a'adai sent a message in reply, expressing his agreement as follows: 'What obstacles are there? Place a capable man in charge of the main base camp and set forth. I shall send out troops from here.'

Having put Oldaqar Qorči in charge of the Great ${ }^{1}$

272 Palaces, in the Year of the Hare (1231) Ögödei Qa'an set out against the Kitat people. He sent forth Jebe as vanguard. Thus he crushed the Kitat troops, slaying them until they were like heaps of rotten logs. He crossed Čabčiyal and ordered his troops to advance and attack their ${ }^{2}$ towns and cities in every direction. Then Ögödei Qa'an pitched camp at Šira Degtür. ${ }^{3}$

There Ögödei Qa'an fell ill. When he lost his speech and was in great distress, various shamans and soothsayers were ordered to divine the cause of the illness. They said, 'The lords and rulers ${ }^{4}$ of the land and rivers of the Kitat are raging violently against the Qa'an now that their people are plundered and their cities and towns are destroyed.' When they divined by inspecting the entrails of victims and said to the lords and rulers of the land and rivers, 'We shall give, as substitute for the Qa'an, people, gold and silver, cattle and food', the illness did not abate

1 I.e., 'the Qa'an's.'

2 I.e., the Kitat's.

3 See above, $\$ 247$ and RSH 2.894.

4 I.e, the powerful spirits. 
and they ${ }^{1}$ raged even more violently. When they divined further by inspecting the entrails and said, "Could a person from the $Q a$ 'an's family serve as a substitute?', the Qa'an, opening his eyes, requested water, drank it and asked, 'What has happened?'

The shamans then reported to the Qa'an as follows: 'The lords and rulers of the land and rivers of the Kitat people are raging violently against you now that their land and waters are destroyed and their people plundered. When we divine by inspecting the entrails of victims and say, "We shall give anything as substitute", with renewed anger they rage even more violently. When we say, "Could a person from the Qa'an's family serve as a substitute?", the illness abates. Now your order shall decide!'

After they had made their report, the Qa'an said, 'Who is at my side from among the princes?' To these words Prince Tolui, who was at his side, said, 'Even though there were elder brothers above you and younger brothers below you, our fortunate father Činggis Qa'an chose you, elder brother the Qa'an, as one would choose a gelding, feeling you as one would feel a wether to make sure it is fat. To your person he showed the great throne and upon you he placed the burden of many people for you to govern. As for myself, I was told by him, "Being at the side of your elder brother the Qa'an,

Do remind him of what he has forgotten,

Do wake him up when he has fallen asleep."2

Now, if I lose you, my elder brother the Qa'an,

Whom shall I remind of what he has forgotten,

Whom shall I wake up when he has fallen asleep? In truth, if my elder brother the Qa'an dies,

The numerous Mongol people

Would be left orphans;

The Kitat people

Would rejoice at their good fortune.

1 I.e., the land and river spirits.

2 Cf. above, $\S \S 200$ and 255. 
I shall take the place of my elder brother the Qa'an.

I have cleft the back of the trout,

I have rent the back of the sturgeon;

I have conquered those in the fore,

I have pierced those afar. $^{1}$

And fair of face,

And tall of stature

am I. Shamans, cast your spells and make your incantations!'

Thus he spoke, and as the shamans made their incantations Prince Tolui drank the magic water. Then he sat for a moment and said, 'I have become drunk. While I recover from my drunkenness, let elder brother the Qa'an decide how best to take care of his younger brothers ${ }^{2}$ who are orphaned and young, and of his younger sister-in-law Berüde who is widowed, until they are able to look after themselves. I have said all I have to say. I have become drunk.' On that, he passed out. Such is the manner in which he died.

273 Then Ögödei Qa'an destroyed the Altan Qan and gave him the name Seüse. ${ }^{3}$ He despoiled him of his gold, silver, gold-embroidered and patterned satins, possessions, piebald horses and young slaves. Having established scouts and garrison troops, and having appointed resident commissioners in Namging, Jungdu and in cities everywhere, he peacefully returned home, setting up camp at Qara Qorum.

274 Cormaqan Qorči brought the Baqtat people under subjection. When Ögödei Qa'an learned that the land was reputedly good and that the things therein were also reputedly good, he ordered as follows: 'Čormaqan Qorči shall reside at that very place as commander of the garrison troops. Every year he shall make people deliver

1 I.e., the enemies who came forward and were near, as well as those who stayed back. See RSH 2.997-98.

${ }^{2}$ Tolui actually means the nephews of Ögödei, i.e. his own sons. Cf. above, $\S 68$.

3 I.e., 'Little Slave.' See RSH 2.1001. 
yellow gold, naq-fabrics, ${ }^{1}$ brocades and damasks with gilded thread, small and big pearls, fine Western ${ }^{2}$ horses with long necks and tall legs, dark brown Bactrian camels and one-humped Arabian dromedaries, pack-mules and riding mules, and he shall send them to Us.'

Batu, Büri, Güyük, Möngge and several other princes who had gone on a campaign in support of Sübe'etei Ba'atur brought the Qanglin, Kibča'ut and Baǰigit people under submission. They crossed the rivers $\mathrm{EJji}^{3}$ and Jayaq, destroyed the city of Meget, slew the Orusut and plundered them until they were utterly crushed. They ravaged and brought under submission the peoples of Asut, Sesüt, Bolar, Mankerman ${ }^{4}$ Kiwa and other cities. Having established resident commissioners and garrison troops they returned home.

Ögödei Qa'an sent Yisüder Qorči on a campaign in support of Jalayirtai Qorči who had earlier on been campaigning against the Jürčet and the Solangqas. He ordered that he reside there as the commander of the garrison troops.

275 From the Kibčaq campaign, through messengers, Batu sent the following report to Ögödei Qa'an: 'By the strength of Eternal Heaven and the good fortune of my uncle the Qa'an, I have destroyed the city of Meget, I have ravaged the Orusut people and brought eleven countries and peoples duly under submission. When we turned back, pulling in the golden reins, ${ }^{5}$ we decided to hold a parting feast. A large tent was set up and, as we began feasting, since I was quite the eldest among those princes who were present, I was the first to drink one or two bowls of the ceremonial wine. Büri and Güyük became angry with me because of that, refused to join the feast and rode off. As they rode off, Büri said, "Since Batu, then, is equal to us, why should he have drunk first?

1 A type of gold brocade fabric produced in western Asia.

2 I.e., Arab.

3 The Idil of $\$ 262$ and Adil of $\$ 270$, i.e. the Volga.

$4=$ Menkermen. For all these names see RSH 2.1009.

5 I.e., at the end of the campaign. Cf. above, $\$ 256$. 
Old women with beards like him,

Who pretend to be one's equal,

One should push with one's heels,

One should trample under one's feet."

On that Güyük said, "Those old women with quivers like Batu - let us also strike their bosoms with a stick of burning wood - those ones!" And Elȳigidei's son Harqasun said, "Let's attach a wooden tail to them!"1 So, just at the time when, having been sent to ride against a rebellious people of a different race, ${ }^{2}$ we were asking ourselves whether we had been successful, Büri and Güyük spoke to us in this way and we parted in disaccord. Now, the order of my uncle the Qa'an shall decide the matter!' Thus he reported.

276 At these words of Batu, the Qa' an became very angry. He did not allow Güyük into his presence but said, 'Following whose counsel does this mean creature fill his mouth with talk against a person senior to him? May he and he alone rot like an egg! He has turned against the bosom of a person who is senior to him. Therefore,

We shall place him in the vanguard:

We shall make him climb the town walls

Which are as high as mountains

Until the nails of his ten fingers are worn away;

We shall place him in the garrison army:

We shall make him climb the town walls

Which are made of hard-pounded earth

Until the nails of his five fingers are ground down.

And you, wretched, wicked, mean Harqasun, in imitation of whom have you filled your mouth with such boastful talk against Our family? Let us send Güyük and Harqasun away together. We could cut down Harqasun, but you would then say that We showed partiality. As for Büri, tell Batu to send him to elder brother Ča'adai, informing him of the matter. Let elder brother Ča'adai decide on it!'

1 To mock them.

2 Lit., 'liver.' 
277 Then Mönggei ${ }^{1}$ from among the princes, and Alčidai, Qongqortāi, Janggi and other commanders from among the commanders, respectfully advised the Qa'an as follows: 'A decree of your father Činggis Qa'an stated that field matters should be decided in the field, just as domestic matters should be decided in the tent. Now, the Qa'an is angry with Güyük. This is a field matter: will the Qa'an not show favour and send Güyük to Batu, entrusting him with the decision?' So they advised him.

The Qa'an approved their words and agreeing to their request allowed Güyük into his presence. He rebuked him with the following words of admonition: 'It is said about you that when you went on the campaign, in the course of it,

You did not leave unlashed the buttocks

Of any man with buttocks;

And it is also said about you that

You crushed the spirit ${ }^{2}$

Of every man in the army.

Do you imagine that the Orusut people have submitted out of fear of that fury and anger of yours? And thinking as if you alone have brought the Orusut people under submission do you now go on, with pride in your heart, rebelling against a person who is senior to you? In the pronouncements of Our father Činggis Qa'an, was he not accustomed to say that

"The multitudes of people make one afraid,

The depth of water makes one die"?

You pretend that you have accomplished it alone, whereas you set out under the shelter of Sübe'etei and Büǰek, and with the full force of the army, to bring the Orusut and Kibča'ut under submission. You took one or two Orusut and Kibča'ut, but while you haven't yet acquired as booty even the hoof of a kid, you make yourself into a hero; having left home but once, you pretend that you alone have accomplished everything and come out with such

1 The Möngge (= Möngke) of $\$ \S 270$ and 274 above.

2 Lit., 'mien (or countenance)', i.e. the morale and self-confidence. 
abusive and provocative language. But now, owing to Mönggei, Alčidai, Qongqortāi, J̌anggi and the others, who

Being at my side as faithful companions

Have restrained my agitated heart,

Being like a broad ladle

Have calmed the overboiling cauldron,

I say, "Right! This is a field matter. They have said that it is Batu's concern. Let then Batu decide on Güyük and Harqasun." He sent them both to him, and said, 'Elder brother Ča'adai shall decide about Büri.'

278 Further Ögödei Qa'an ordered: 'In proclaiming the present order which announces anew the duties of all the guards - nightguards, quiverbearers and dayguards - who have served my father Činggis Qa'an, I command that in whatever capacity they previously acted in accordance with the order of my father the Qa'an, so shall they act in the same capacity now. The quiverbearers and the dayguards shall, in accordance with the previous order, carry out their day duties, each at his post. While there is still sunlight, they shall retire so as to be replaced by the nightguards and they shall spend the night outside.' ${ }^{1}$ So he ordered.

And he ordered the following: 'At night, the nightguards shall spend the night beside Us. The nightguards shall stand at the door and around the Palace tent. The nightguards shall patrol the rear and front of the Palace. The nightguards shall seize people who move about at night - after sunset - and shall hold them in custody for the night. After the multitude of men has dispersed, except for those nightguards who have spent the night on duty and are to be relieved, the nightguards shall seize anyone who by mingling with them has entered the precinct. $^{2}$ They shall split their heads open and shall cast them away. If at night a person comes with an urgent message he must report to the nightguards and communicate the message to me while standing together with

1 Cf. above, $\$ 229$.

2 Lit., 'inside.' 
the nightguards at the rear ${ }^{1}$ of the tent. The supervisors Qongqortai, Šraqan and others, together with the nightguards, shall supervise all comings and goings at the Palace tent. And because Eljigidei, even though he was a trustworthy person, was arrested by the nightguards when in the evening he happened to walk up beyond them, the nightguards too, who like those who arrested Eljigidei do not contravene the orders, are worthy of confidence.' Thus he spoke, and issued the following order: 'One must not ask the number of nightguards. One must not walk beyond the nightguards' post. One must not walk between the nightguards. The nightguards shall arrest the people who walk beyond or between them. ${ }^{2}$ With regard to any person who shall have asked their ${ }^{3}$ number, the nightguards shall seize the gelding that that person was riding that day, with saddle and bridle, together with the clothes that he was wearing. No one is to sit above the place of the nightguards. The nightguards shall take care of the standards and drums, and of the spears, bowls and vessels arranged beneath them. The nightguards shall supervise drink and food - the uncut meat., ${ }^{4}$

And he ordered: 'The nightguards shall take care of the tent-carts of the Palace. If We Ourselves do not go on a military campaign, the nightguards must not take the field separately and without Us. ${ }^{5}$ When We go falconing or hunting, exactly one half of the nightguards shall stay at the tent-carts of the Palace and the other half shall go with Us. The campmasters from among the nightguards shall go before Us and set up the Palace. The doorkeepers from among the nightguards shall stand right next to the door. The commander of a thousand Qada'an shall be in charge of all the nightguards.'

Further, when he appointed the commanders of the various companies of nightguards, he said, 'Qada' an and

\footnotetext{
I.e., at the northern side.

2 Lit., 'who walk between the nightguards.'

3 Lit., 'of the nightguards.'

${ }^{4}$ Cf. above, $\$ 232$.

5 Cf. above, §233.
} 
Bulqadar, forming one company, shall consult together; when taking the same turn of duty they shall stay on the right and left ${ }^{1}$ side of the Palace respectively and marshal their guards accordingly. Amal and Čanar, consulting together, shall form one company; when taking the same turn of duty, they shall stay on the right and left side of the Palace respectively and marshal their guards accordingly. Qadai and Qori Qačar shall consult together and, when taking the same turn of duty, they shall stay on the right and left side of the Palace respectively and marshal their guards accordingly. Yalbaq and Qara'udar, consulting together, shall form one company; when taking the same turn of duty, they shall stay on the right and left side of the Palace respectively and marshal their guards accordingly. Further, the company of Qada'an and Bulqadar, and the company of Amal and Canar - these two companies - shall encamp on the left ${ }^{2}$ side of the Palace and take their turn of duty there. The company of both Qadai and Qori Qačar and the company of both Yalbaq and Qara'udar - these two companies - shall encamp on the right ${ }^{3}$ side of the Palace and take their turn of duty there.'

And he ordered: 'Qada' an shall be in charge of these four companies of nightguards. Further, the nightguards shall stand around the Palace right next to my person, and they shall lie down guarding the door. ${ }^{4}$ Two men from the nightguards shall enter into the Palace and be in charge of the large kumis pitchers.'

Further he ordered: 'As to the quiverbearers, Yisün Tö'e, Bükidei, Horqudaq and Labalqa, ${ }^{5}$ forming four separate companies and marshalling their quiverbearers of the bodyguards, shall respectively join the four separate companies of the dayguards to carry quivers.'

1 I.e., west and east.

2 I.e., east.

3 I.e., west.

4 Cf. above, §229; here 'lie down' and 'stand' are incorrectly reversed. See RSH 2.1023.

5 = Lablaqa. See above, $§ 225$. 
Further, when he appointed elders ${ }^{1}$ of the dayguards' companies from among the offspring of those who had earlier been in charge of them, he ordered: 'Alčidai and Qongqortaqai ${ }^{2}$ who were earlier in charge of them, after consulting together and having marshalled one company of dayguards, shall join the dayguards' service. Temüder and Jegü after consulting together and having marshalled one company of dayguards shall join the dayguards'service. Mangqutai, who had been in charge of the reserve, shall marshal one company of dayguards and join the dayguards' service.'

Further, the Qa'an ordered as follows: 'Elyjigidei shall be in command of the Guard and all the commanders of companies shall act according to Elÿigidei's word.'

Further, he ordered: 'If a member of the Guard when called on duty fails to take his turn, in accordance with the previous order $^{3}$ he shall be disciplined with three strokes of the rod. If the same member of the Guard fails again - for the second time - to take his turn of duty, he shall be disciplined with seven strokes of the rod. If, once more, the same man, without sickness or other reason and without having first consulted the elder of the company, for the third time fails to take his turn, thus regarding his service by Our side as too difficult, he shall be disciplined with thirty-seven strokes of the rod and shall be sent to a distant place out of Our sight. Further, if the elders of the companies do not muster the guards who are to serve on roster with them and fail to take their turn of duty, We shall punish the elders of the companies. Further, the elders of the companies shall proclaim this order to the guards at the time when they ${ }^{4}$ take every third turn of duty $^{5}$ and at the time when they are relieved. When the guards have heard the order, if they fail to take their turn of duty We shall punish them according to the previous

I.e., the senior officers. See above, $\$ 227$.

2 = Qongqortāi. See above, $\$ 277$.

${ }^{3}$ See above, $\$ 227$.

${ }^{4}$ I.e., the guards.

${ }^{5}$ I.e., every third shift. 
order. ${ }^{1}$ But if the elders of the companies do not proclaim this order to the guards they shall be guilty and liable to punishment. Further, elders of the companies without permission from Us shall not, merely on the ground of seniority, reprimand my guards who have enrolled as guards equal to them. If any of them breaks the law let it be reported to Us. Those liable to death We shall certainly cut down. Those liable to punishment We shall certainly discipline. If, without informing Us, they themselves ${ }^{2}$ on the ground of seniority lay hands on $m y$ guards, as requital for fists they shall be repaid with fists, and as requital for strokes of the rod they shall be repaid with strokes of the rod. ${ }^{3}$ Thus he spoke.

Further, he ordered as follows: 'My guards are of higher standing than the outside commanders of a thousand; the attendants of my guards are of higher standing than the outside commanders of a hundred and of ten. If outside leaders of a thousand quarrel with my guards We shall punish those who are leaders of a thousand. ${ }^{4}$

279 Further, Ögödei Qa'an said, 'We shall not cause suffering to the nation that Our father Činggis Qa'an established with so much toil. We shall make the people rejoice, causing them to rest

Their feet upon the ground,

Their hands upon the earth.

Sitting now on the throne made ready by Our father the Qa'an, so that people do not suffer, every year from these people one two-year-old sheep out of every flock shall be given as levy for Our soup. ${ }^{5}$ They shall also provide one sheep out of every hundred sheep and give it to the poor and needy within the same unit. And when the Qa'an's brothers and the numerous troops ${ }^{6}$ and guards gather

1 See above, $\$ 227$ ad fin.

2 I.e., the elders of the companies.

3 See above, \$227 ad fin.

4 See above, $\$ 228$.

5 I.e., for the support of the Qa'an.

6 I.e., the Qa'an's family and the officers. 
together at feasts and meetings, how could drink for all be levied every time from the people? From the various units of a thousand of different areas mares shall be provided and milked, and the mare-milkers shall be the ones to tend them. The camp-masters shall constantly provide replacements of mares and shall in turn be herders of the milch mares. And when the Qa'an's brothers gather together We shall give them gifts and rewards. Conveying satins, gold and silver ingots, quivers, bows, breastplates, weapons and the land-tax grains into the storehouses, We shall have people guarding them: storemen and grainkeepers must be selected from different areas and made to guard the storehouses. And, dividing camps ${ }^{1}$ and waters, We shall give them to the people. If We select campmasters from the various units of a thousand to reside in the camps, that will surely be an appropriate measure.

'Moreover, as there is nothing but wild animals in the Čöl ${ }^{2}$ country, Čanai and Ui'urtai, being put in charge of the campmasters, shall make them dig wells in the Č̈l for people to live in this rather vast area, and they shall build brick walls around the wells to protect them from wild animals.

'Further, when the messengers ride in haste We allow them to ride moving freely among the population, and as a result the pace of these riding messengers is slow and they are an affliction on the people. Now We shall settle the matter once and for all by providing post-station masters and post-horse keepers from the various units of a thousand of different areas, by setting up a post station at every stage, by not allowing the messengers to move freely among the population unless on urgent business, but instead by having them ride in haste through the post stations. If we do this, it will surely be an appropriate measure.

1 I.e., the grazing grounds (nuntuq).

2 Lit., 'the Desert' (= the Gobi; cf. above, §188), but perhaps more generally 'the desert country' (RSH 2.1027). 
'When Čanai and Bolqadar,' being well informed, proposed these measures to Us We considered that they were indeed right and said, "Let elder brother Ča'adai decide. If these measures under discussion are appropriate and he approves them, let the decision come from elder brother Ča'adai."”

After Ögödei Qa'an had sent this message, a reply came from elder brother Ča'adai, saying, 'I approve these very measures about which you have asked me in your message - all of them. Thus, act accordingly!'

Further, elder brother Ča'adai's word came, saying, 'From here I shall have post stations connecting with yours. ${ }^{2}$ Also, from here I shall send messengers to Batu, and Batu shall have his post stations connected with mine.' And a further word came from him, which he sent saying, 'Of all the measures, the one concerning the establishment of post stations is the most appropriate that has been proposed.'

280 Thereupon Ögödei Qa'an said, 'Elder brother Ča'adai and Batu, and the other brothers, princes of the right hand $^{3}$ - all of them; Otčigin Noyan and Yegü, and the other brothers, all the princes of the left hand; ${ }^{4}$ the princesses and sons-in-law of the centre, and the commanders of ten thousand, of a thousand, of a hundred and of ten, have all together approved the following: "If, for the soup of the Universal Ruler ${ }^{5}$ one provides every year one two-year-old wether out of every flock, it won't be a burden at all. To provide one one-year-old sheep out of every hundred sheep and give it to the poor and needy is good. If we have post stations set up and provide poststation masters and post-horse keepers to manage them there will be peace for the many peoples, and for the messengers in particular convenience in travelling." They unanimously approved this.'

1 The Bulqadar of $\$ 278$ above.

2 I.e., to facilitate communications.

3 I.e., of the west.

4 I.e., of the east.

5 I.e., for the support of the Qa'an. Cf. above, $\$ 279$. 
Having taken counsel with elder brother Ča'adai regarding the order of the Qa'an, and this having been approved by elder brother C̆a'adai, all the people from the various units of a thousand of different areas according to the Qa'an's order were made to provide every year one two-year-old wether out of every flock for the soup of the Qa'an, and one one-year-old sheep out of every hundred sheep for the poor and needy. They were made to provide mares, and herders of milch mares were also assigned. They were made to provide herders of milch mares, storemen and grainkeepers. They were made to provide post-station masters and post-horse keepers, and measuring the distance between each stage they had post stations set up. Aračan and Toqučar were put in charge of them. At a single stage of the post there had to be twenty post-horse keepers, and at every stage there had to be $a$ post station with twenty post-horse keepers each.

The Qa'an ordered: 'With regard to the geldings to be used as post horses, the sheep to be used as provisions, the milch mares, the oxen to be harnessed to carts, and the carts, from the amount fixed by Us from now on,

If one causes even a piece of string to be lacking, He shall be guilty and liable

To "splitting in half along the top of the head"; 1

If one causes even a spoon-shaped spoke of a wheel to be lacking,

He shall be guilty and liable

To "splitting in half along the nose.",

281 Ögödei Qa'an said, 'This I have done after I sat on the great throne of my father:

'I campaigned against the Jaqut people ${ }^{2}$ and I destroyed them. ${ }^{3}$

'As my second deed, I had post stations set up so that our messengers could ride in haste all along the way; and for that purpose I had all necessities conveyed to the post stations.

${ }^{1}$ I.e., to the confiscation of half his goods. See RSH 2.1031-32.

2 I.e., the people of north China. See RSH 2.1032-33.

${ }^{3}$ Lit., 'I destroyed the Jaqut people.' 
'As to the next ${ }^{1}$ deed, I had wells dug in places without water and had the water brought forth, thus providing the people with water and grass.

'Further, ${ }^{2}$ I established scouts and garrison troops among the people of cities everywhere and so I let the people live in peace, causing them to rest

Their feet upon the ground,

Their hands upon the earth. ${ }^{3}$

'After my father the Qa' an I have indeed added four good deeds to his.

'But, being placed on the great throne by my father the Qa' an and being made to take upon myself the burden of my many peoples, I was at fault to let myself be vanquished by wine. This was indeed one fault of mine.

'As to my second fault, to listen to the word of a woman without principle, and to have the girls of my uncle Otčigin's domain brought to me was surely a mistake. ${ }^{4}$ Even though I was the Qa'an and lord of the nation, to participate in wrong and unprincipled actions, this was indeed one fault of mine.

'To secretly injure ${ }^{5}$ Doqolqu was also a fault of mine. And why was it a fault? Because to secretly injure Doqolqu who strove fiercely in the service of his rightful lord, my father the Qan, was a fault and a mistake. Who will now strive so fiercely in my service? Therefore, I have myself acknowledged the fault of having secretly harmed, without discernment, a person who diligently observed the principle of loyalty in the service of my father the Qa' an and in the service of all.

'Further, ${ }^{6}$ being greedy and saying to myself, "What if

1 I.e., the third.

2 I.e., as the fourth deed.

3 See above, $\$ 279$.

${ }^{4}$ For this complicated incident, nowhere mentioned in the Secret History, see RSH 2.1034-36. 37 .

5 = 'poison'? Cf. above, $\S 68$. And for this third fault, see RSH 1036-

${ }^{6}$ I.e., as the fourth fault (for which we have no direct additional evidence). See RSH 2.1037-38. 
the wild animals born with their destiny ordained by Heaven and Earth go over to the territory of my brothers?", I had fences and walls built of pounded earth to prevent the animals from straying. As I was thus confining them, I heard resentful words coming from my brothers. That, too, was a fault of mine.

'After my father the Qa'an, I indeed added four good deeds to his, and four deeds of mine were surely faults.' Thus he spoke.

282 The writing of this book was completed at the time when the Great Assembly convened and when, in the Year of the Rat, in the month of the Roebuck, the Palaces were established at Dolo'an Boldaq of Köde'e Aral on the Kelüren River, between Šilginček and [...]. ${ }^{1}$

${ }^{1}$ The name of the second locality is missing owing to a lacuna in the text. 


\section{INDEX}

\section{PROPER AND PLACE NAMES}

The index below uses boldface type to refer to sections (not pages) of the SH translation; the sign + after a number indicates that the name occurs in that section more than once. Please note the following abbreviations:

$$
\begin{array}{ll}
\text { cl. = clan } & \text { cmdr. = commander } \\
\text { dau. = daughter } & \text { des. }=\text { desert } \\
\text { lk. = lake } & \text { mt. }=\text { mountain, any elevation } \\
\text { peo. = people[s], tribe, nation } & \text { pl. }=\text { place, locality, } \\
\text { pr. = person, any individual } & \text { rv. }=\text { river, any water-course }
\end{array}
$$

Abǰi’a Ködeger (mt.), 187; also Abǰiqa Köteger 191

Abtu (pl.), 261

Ačiq Širun (pr.; of the Tümen Tübegen of the Kereyit), 170+, 171+, 174+, 181

Adangqan Uriangqai (cl.), 38, 44; man of, 44 (see also J̌ăiradai); woman of, $\mathbf{3 8}, \mathbf{4 0}$

Adargin (cl.), 46, 260: see also Adarkin

Adarkidai (pr.; son of Qači'un), 46

Adarkin (cl.), 207: see also Adargin

Adil (rv.; tu. Ïtïl, 'Volga'), 270; see also Ejil, Idil

Ai-tsung (pr.): see Altan Qan [Ai-tsung of Chin], Seüse

Ajai Qan (pr.), 152+

Aj̆in Be'i (pr.): see Qoǰin Beki

Ajinai (pr.; cmdr. of 1000), 202

Al Altun (pr.; a dau. of Činggis Qan), 238. Also Al Altun Beki, Ilqaltun Beki

al-Mustanșir (pr.): see the Qalibai Soltan

Alai (pl.), 198+, 257. Also Arai

Alan Qo'a (pr.; dau. of Qorilartai Mergen; wife of Dobun Mergen), 7, 8,

9, 10, 17, 18+, 20, 22+, 23; see also Mother Alan

Alans (peo.): see Asut

Alaq (pr.; son of Širgü'etü; cmdr. of 1000), 149+, 202, 220

Alaq It (pr.; wife of Yeke Čeren), 169

Alaqa Beki (pr.; a Mongolian princess), 239

Alaquš Digit Quri (pr.; of the Önggüt; cmdr. of 1000), 182, 190+; also

Alaquš Digit Quri Güregen, 202

Alašai (mt., and battle there), 265+. Also Ho-lan Mountains

Ala'ut Turqa'ut Mountains (mt.), 129 
Alči [a] (pr.; cmdr. of 1000), 202, 253. Also Alči Noyan

Alči [b] (pr.), 226. Also Alči Noyan (?)

Alči Güregen (pr.; cmdr. of 1000), 202. Also Alči Noyan

Alči Noyan (pr.): see Alči Güregen; also Alci [b] (?)

Alči Tatar (cl.), 141, 153+

Alčidai (pr.; nephew of Činggis Qan), 170, 242, 243, 255

Alčidai (pr.; of the J̌alayir; of family of Ilügei; cmdr. of 1000 dayguards), 226, 227, 234, 277+, 278. Also Alǰidai, Elčidei, Elǰidei

Alčiq (pr.; a steward), 208

Aldi Er (pr.; a chief of the Kirgisut), 239

Alin Taiši (pr.), 152

Alǰidai (pr.): see Alčidai [of the J̌alayir]

Alqui (pr.; of the Onggirat), 141

Alqui Bula'a (pl.; 'Sarsaparilla Spring'), 141

Altai (mt.), 144, 158+, 177, 194+, 196, 198, 205

Altan (pr.; $3^{\text {rd }}$ son of Qutula Qan), 51, 123, 127+, 142+, 153, 166+, 168,

174, 179+, 180, 181, 246, 255+; also Altan Otčigin, 122

Altan Qa'an (pr.; Hsüan-tsung of Chin; ruled 1213-23), 250, 251; also

Altan Qan, 248+, 250, 251+, 252+, 253+; see also Aqutai

Altan Qan (pr.; Ai-tsung of Chin; personal name Shou-hsü; ruled 1224-

34), 271, 273; see also Seüse

Altan Qan (pr.; Chang-tsung of Chin; ruled 1189-1208), 53, 132, 133,

134+, 266

Altan Qorqan (mt.), 259

Altani (pr.), 214+

Altun Ašuq (pr.; of the Kereyit), 152+

Amal (pr.; cmdr. of nightguards), 278+

Ambaqai Qa'an (pr.; a son of Čaraqai Lingqu; ruler of the Mongols), 47,

$52,53+, 57,58,70,71$

Amīn al-Mulk/Amīn Malik (pr.): see Qan Melik

Amui Müren (rv.; 'Amui River' = Amu Darya, the Oxus), 258

Aqutai (pr.; of family of Alči; cmdr. of 1000 dayguards), 226, 234

Aqutai (pr.; Hsüan-tsung of Chin), 250, 251; see also Altan Qa'an/Qan

Aračan (pr.), 280

Arai (pl.): see Alai

Arbuqa (pl.), 265, 267

Ariq Usun (pl.), 8, 9

Arqai (pr.; of the J̌alayir; cmdr. of dayguards), 181+, 185, 230, 234; also

Arqai Qasar, 120, 124, 127, 177, 181+, 191, 192, 226, 252+

Arqal Geügi (pl.; of the Kelüren), 183+, 184

Arslan (pr.; of the Qarlu'ut), 235; also Arslan Qan, 235+. Later renamed

Arslan Sartaqtai (RSH 2.843)

Arulat (cl.), 47, 120

Aruqai Tatar (cl.), 153+

Asan (pr.; = Hasan; a Muslim trader), 182 
Asut (peo.; plural of As; the Alans or Ossets of the Caucasus), 262, 270, 274

Aša Gambu (pr.; of the Tang'ut), 256+, 265+, 266

Ašiq (pr.; of the Ba'arin), 207; also Ašiq Güregen (cmdr. of 1000), 202

Ašiq Temür (pr.; a steward), 208+

Atkiraq (pr., an ambassador of the Ui'ut), 238

A'uču Ba'atur (pr.; of the Tayici'ut), 141, 142, 144+, 148

A'uǰam Boro'ul (pr.; son of Qoričar Mergen), 2+

Ayil Qaraqana (pl.), 107, 122+

Ayiri'ut Buiru'ut Tatar (cl.), 53

Ba'aridai (pr.; a son of Bodončar), 41+; see also Elder Brother the Ba'arin

Ba'arin (peo.), 41, 120, 197, 207, 216

Badai (pr.; cmdr. of 1000), 51, 169+, 170, 187+, 202, 219

Baghdad (pl.): see Baqtat

Bai Šingqor Doqšin (pr.; son of Qaidu), 47+

Baikal (lk.): see Lake Baikal, Tenggis

Bajigit (peo.; the Bashkir), 239, 262, 270, 274

Bala (pr.; a son of Seče Domoq of the J̌alayir; cmdr. of 1000), 120, 202,

243, 257, 259, 264+. Also Bala Noyan

Bala Čerbi (pr.; cmdr. of 1000), 202

Balaqači (pr.; messenger of Ambaqai Qan), $\mathbf{5 3}$

Baljun Aral (pl.), 24

Baljuna (lk.): see Lake Balǰuna

Baqaji (pr.; of the Tayiči'ut), 177

Baqtat (pl.; Baghdad), 260+, 261, 270, 274

Bargut/Baryut, Bargu Buriat (peo.): see Barqun, Buriats

Barguzin Buriat (peo.): see Buriats

Barguzin River (rv.); see Barquǰin Lowland (Baryujin Tögüm)

Barim Ši'iratu Qabiči (pr.; son of Bodončar), 43; see also Qabiči Ba'atur

Barqaq (pr.; eldest son of Qabul Qan), 140; also Barqaq Ba'atur 179; see also Ökin Barqaq

Barqudai Mergen (pr.), 8

Barqujin (pl.), 109

Barqujin Lowland (pl.; Baryujin Tögüm; inhabited by the Qori Tumat),

157, 177+, 244; see also Köl Barqujuin Lowland

Barqujin Qo'a (pr.), 8+

Barqun (peo.; plural Barqut), 239; see also Buriats

Bartan Ba'atur (pr.; 2 ${ }^{\text {nd }}$ son of Qabul Qan), 48, 50, 140+; in 179 error for Barqaq Ba'atur

Baru'an Plain (pl.), 257; 258 (where wrongly written Barula). Also Parwan/Parvān

Barulas (peo.), 46+, 120+; see also Erdemtü Barula, Tödö’en Barula, Üčügen Barula, Yeke Barula 
Barulatai (pr.; son of Qači’u), 46

Bashkir (peo.): see Baj̆igit

Batačiqan (pr.; son of wolf and doe), 1, 2

Batkesen (pl.; Badakhshan [in Eastern Afghanistan]), 257

Batu (pr.; son of J̌oči), 269, 270+, 274, 275+, 276+, 277+, 279+, 280

Baya'ut (peo.), 120, 213+; thousand, 213; see also Ma'aliq Baya'ut

Bayidaraq Confluence (pl.); 159, 177

Bayit (peo.), 239

Beder Promontory (pl.), 88

Bedü'ün (pr.; of the Dörbet; joint cmdr. of 1000 with Qubilai), 209; see also Moči Bedü'ün

Beiging [or Buiging] (pl.; Pei-ching, northern capital of the Chin; Peking), 253+; see also Jungdu (Chinese Chung-tu)

Bekter (pr.; a half brother of Temüjin), 60, 76+, 77+

Belgünüt (cl.), 42

Belgünütei (pr.; a son of Dobun Mergen), 10, 18, 19, 20, 23, 42

Belgütei (pr.; a half brother of Temüjin), 50, 60, 76+, 77, 79, 90+, 94, 95+, 96, 99, 101, 103, 104, 105+, 107, 112+, 124, 131+, 132, 134, 136, 140+, 154+, 205, 242, 255; also Belgütei Noyan, 112, 190, 191

Berke Elet (pl.), 166

Berüde (pr.; $2^{\text {nd }}$ dau. of Jaqa Gambu; wife of Tolui), 272; see also Sorqaqtani Beki

Besüt (cl.), 47, 53, 119, 120, 138

Besütei (pr.; a son of Čaraqai Lingqu), 47

Bilge Beki (pr.; a messenger of Ong Qan), 142, 181+

Black Forest by the Tu'ula River (Qara Tün) (pl.), 96, 104, 115, 164, $177+, 264$

Black Forest Tatars (peo.): see Tubas

Black Irtysh (rv.): see Erdis/Erdiš River

Bodončar (pr.; a son of Alan Qo'a), 23, 24, 28, 29+, 32, 33, 34, 35, 37,

38, 40, 41, 42, 43+, 44, 121; also Bodončar Mungqaq, 17, 19, 30;

Bodončar Boqdo, 121

Bolar (peo.; the Volga Bulgars), 262, 274; in 270 error for Buqar

Bolyar (peo.): see Bolar

Bolqadar (pr.; a commissioner of post stations under Ögödei), 279; see also Bulqadar

Bo'orču (pr.; son of Naqu Bayan; cmdr. of 10,000; with J̌elme appointed in command of all; one of the 'four steeds'), 90+, 91, 92, 93+, 99, $103,120+, 124,125,156,163,172+, 177,202,203+, 205+, 210,220$, 226, 240, 242+, 254+, 260, 266+

Borǰigidai Mergen (pr.; son of Qarču), 3+

Borǰigin (cl.), 42. See also Kiyat-Borǰigin lineage in Subject Index, and RSH 1.238, 280, 297-99

Boro (name of gelding; 'Grey'), 3

Boroldai (pr.; of the Ikires), 129 
Boroldai Suyalbi (pr.; a young manservant of Toroqolyin Bayan), $\mathbf{3}$

Boroqčin Qo'a (pr.; wife of Toroqoljin Bayan), 3

Boroqul (pr.; foundling; of the Jürkin; cmdr. of 1000, 10,000; one of the

'four steeds'), 163, 172+, 173+, 177, 202, 209, 214+, 241; also Boroqul Noyan, 240+; Boro'ul, 137, 138, 213+; Boro'ul Noyan, 240

Botoqan Bo'orji (pl.), 106+, 108; also Botoqan Bo’orjin, 109

Botoqui Tarqun (pr.; widow of Daiduqul Soqor, ruler of the Tumat; a wife of Quduq Beki), 240, 241+

Botu (pr.): see Butu

Bögen (pr.; cmdr. of 1000), 202

Börte (pr.; dau. of Dei Sečen of the Onggirat; wife of Temüjü), 66, 98-

103, 104, 105, 110+, 111, 118, 245, 254; see also Lady Börte

Börte Činō (pr.; 'blue-grey wolf') 1

Bučaran Čerbi (pr.; a steward/chamberlain), 191

Buda'at (cl.), 46

Buddha (pr.): golden images (altan süme-s) of, 267

Buiging (pl.): see Beiging

Buir Nōr (lk.): see Lake Buyur

Buǰir (pr.; cmdr. of 1000), $\mathbf{2 0 2}$

Bukhara (pl.): see Buqar

Bukhtarma River (rv.): see Buqdurma

Bulqadar (pr.; a commissioner of post stations under Ögödei), 278+; see also Bolqadar

Bultaču Ba'atur (pr.): see Bültečü Ba'atur

Buluqan (pr.; cmdr. of 1000), 202

Buqa (pr.; younger son of Gü'ün U'a of the J̌alayir; brother of Muqali; cmdr. of dayguards), 137, 226, 227, 234

Buqa (pr.; J̌oči's guide; identity not clear), 239

Buqa Güregen (pr.; cmdr. of 1000), 202

Buqa Temür (pr.; younger brother of Ong Qan), 177

Buqar (peo.), 270 (error for Bolar, q.v.)

Buqar (pl.; Bukhara [Buxāra]), 257, 259, 263

Buqatai (pr.; messenger of Činggis Qan to Senggüm), 168+

Buqatu Salǰi (pr.; a son of Alan Qo’a), 17, 19, 23, 42

Buqdurma (rv.), 198. Also Bukhtarma River

Buqu Čorogi (pr.; of the Qadagin), 141

Buqu Qatagi (pr.; a son of Alan Qo'a), 17, 19, 23, 30, 32, 33+, 42

Buriats (peo.); also Buriyat, 239; also Bargut, Barguzin Buriat, Barqun/Barqut, Ekhirit-Buriat

Burqan (mt.), 103, 112, 145; see also Burqan Qaldun

Burqan (pr.; ruler of the Qašin/Tang'ut), 250, 256+, 265+, 267+; see also Burqan Qan

Burqan Bosqaqsan (pr.; one of two 'Lords of [Mt.] Burqan Qaldun'; but note RSH 3.48-49), 9 
Burqan Qaldun (sacred mountain, original home of the Mongols), 5+, 9+, 89, 97, 102+, 103+; see also Burqan, Mount Burqan, Qaldun Burqan. Also Khentei Khan

Burqan Qan (pr.; 'Buddha [= Divine] Ruler' of the Hsi Hsia kingdom), 249+, 267); see also Burqan, Iluqu, Šidurqu. Also Hsiang-tsung [= Li An-ch'üan; ruled 1206-11]; Iluqu/Iluqu Burqan/Iluqu Burqan Šidurqu, Li Hsien [ruled 1226-27]; Li Tsun-hsü [ruled 1211-23]

Butu (pr.; son of Nekün of the Ikires; Temüjin's brother- and son-in-law; cmdr. of 1000), 120; also Butu Güregen, 202. Also Botu (RSH 1.447)

Bu'ura Steppe (pl.), 105, 109, 152

Buyiruq Qan (pr.; of the Naiman; cf. tu. title buïruq), 141, 142, 143, 144, 158+, 177

Buyur (lk.): see Lake Buyur

Bügidei (pr.; son of Tüge; cmdr. of a company of quiverbearers), 225+, 230, 278; see also Bükidei

Bügünüt (cl.), 42

Bügünütei (pr.; a son of Dobun Mergen), 10, 18, 19, 20, 23, 42

Büjek (pr.; a general in the Orosut campaign), 277

Bükidei (pr.), 234, 278; see also Bügidei

Bültečü Ba'atur (pr.; son of Sem Sečüle), $\mathbf{4 8}$ (error for Bultaču Ba'atur, RSH 1.287)

Bürgi Escarpment (pl.; of the Kelüren River), 96, 97, 98, 107+, 177

Büri (pr.; grandson of Ča'adai), 270+, 274, 275+, 276, 277

Büri (pr.; son of Qutuqtu Möngler), 140; also Büri Bökö ('Büri the wrestler'), 50, 131+, 140+

Büri Bulčiru (pr.; son of Tügü'üdei), $\mathbf{4 0 +}$

Caucasia, north: reconnaissance raid in by Sübe'etei (and J̌ebe), 262

Ch'a-erh (pr.): see Čaqa

Chang-tsung [of Chin] (pr.): see Altan Qan [Chang-tsung]

Chao Kuan [of Sung] (pr.): see J̌au Gon

Ch'i-kuo (pr.): see Gung u

Ch'i-lien Mountains (mt.): see Čo'orqat

China, north: epidemics in, 248

Chu River (rv.): see Čui River

Chung-hsing (fu) (pl.): see Eriqaya

Chung-tu (pl.): see J̌ungdu

Chü-yung kuan (pl.): see Čabčiyal

Circassians (peo.): see Sergesüt

Comans (peo.): see Kibča'ut

Cyriacus (pr.): see Qurčaqus

Ča'a'an Tatar (cl.; 'White Tatars'), 153; see also Ča'ān Tatar

Ča'adai (pr.; $2^{\text {nd }}$ son of Temüjin), 242, 243+, 254+, 255+, 258+, 260+, $269+, 270+, 271+, 276+, 277,279+, 280$ 
Ča'alun (pr.), 157

Ča'ān Tatar (cl.), 153; see also Ča'a' an Tatar

Čabčiyal (pl.), 247+, 251, 252+, 272; also Čabčiyal Pass, 247, 248, 253.

Also Chü-yung kuan

Čakirma'ut (pl.), 195+

Čanai (pr.; of the family of Jürcedei), 226, 234, 279+

Čanar (pr.; military officer in the service of Ögödei), 278+

Čangši'ut (peo.), 120, 213

Čaqa (pr.; dau. of Iluqu Burqan of the Tang'ut), 249

Čaqa'an Qo'a (pr.; cmdr. of 1000), 202; also Čaqān Qo'a, 218+; Čaqa'an U'a, 120, 129

Čaqurqan (pr.; of the Uriangqai), 183+, 184+, 185; also Ča'urqai, Ča'urqan

Čaraqa (pr.): see Old Čaraqa

Čaraqai Lingqu (pr.; $2^{\text {nd }}$ son of Qaidu), 47+, 180

Časutu Mountain (mt.; 'Snowy Mtn.'), 266, 267. Also Hsüeh-shan

Čaujin Örtegei (pr.; son of Qaidu), 47+

Ča'ur Beki (pr.), 165+, 168+

Ča'ur Sečen (pr.): see Taiču Güregen.

Ča'urqai (pr.; cmdr. of 1000), 202, 243; see also Čaqurqan, Ča'urqan

Ča'urqan (pr.; a son of J̌arči'udai of the Uriangqai; cousin of J̌elme),

120, 124, 127; see also Čaqurqan, Ča'urqai. Also RSH2.868-89

Čečeyigen (pr.; a dau. of Temǚ̆in), 239

Čeren (pr.; son of Qulan Ba'atur), 219; see also Yeke Čeren

Čerkes (peo.): see Sergesüt

Čiduqul Bökö (pr.; son of Ba'aridai), 41

Čigidei (pr.), 170

Čigü Güregen (pr.; son of Alči Noyan; husband of Tümelün; cmdr. of 1000), 202; see also Čügü Gürigen

Čila'un (pr.; younger son of Sorqan Šira of the Suldus; one of the 'four steeds'), 84, 85, 219; also Čila'un Ba'atur, 163, 177, 209

Čila'un (pr.; son of Toqto'a Beki of the Merkit), 157, 162, 177, 197, $198+, 199+, 236$

Čila'un Qayiči (pr.; $2^{\text {nd }}$ son of Telegetü Bayan of the J̌alayir), 137+

Čiledü (pr.; of the Merkit; $1^{\text {st }}$ husband of Hö'elün), 55+, 56, 102, 111; see also Yeke Čiledü

Čilger/Čilger Bökö (pr.; of the Merkit), 111+

Čilgütei (pr.; of the Suldus), 120, 124; see also Čülgetei (?)

Čimbai (pr.; elder son of Sorqan Šira of the Suldus), 84, 85, 198+, 219+

Činggis Qa'an (pr.; title of Temüj̆in, eldest son of Yisügei and Höelün; husband of Börte, father of J̌öči, Č́a'aday, Ögödei, and Tolui), 1, 124, $125+, 127,129+-136+, 137,139+-142+, 144+-151+, 153+-157+, 158$, $159+, 161+, 163+-166+, 168+-173+, 175+, 176+, 177,179+, 180$, $181+, 188+, 190+, 191,192+, 193+, 196+-204+, 205,206,208+, 209-$ 212, 213+, 214-217, 218+-220+, 221-223, 224+, 225, 226+, 227+, 
228-234, 235+, 238+, 239+, 240, 241+, 242, 243+-260+, 261, 263+269+, 270-272, 277+, 279; also Činggis Qan, 255, Činggis, 124. See also Temüjin. (For details on all the above paragraphs, see RSH 2.1204-05. For his death, and locations of his grave and former 'palace', see RSH 2.981-83, 3.123ff.)

Činōs (peo.), 129, 207; see also Negüs

Čiqurqu (mt.): see Mount Čiqurqu

Čirgidai Ba'atur (pr.; of the Saljì'ut), 141

Čoči Darmala (pr.; of the Mongols), 201; see also J̌oči Darmala

Čonaq Čaqa'an (pr.), 141; see also Čo'os Čaqān

Čo'orqat (pl.), 265+. Also Ch'i-lien Mountains

Čo'os Čaqān, 182; see also Čonaq Čaqa'an

Čoqčaran (rv.): see Čuqčeren. Also Herirud

Čormaqan (pr.), 260+; also Čormaqan Qorči 260, 270, 274+

Čotan (pr.; wife of Dei Sečen; mother-in-law of Temüy̆in), 94+, 95, 96

Čöl (des.), 188+, 279+. Also Gobi desert

Čui River (rv.), 152, 177, 198, 236

Čuqčeren (pl.), 259+; erroneous transcription for Čoqčaran (RSH 2.948)

Čügü Gürigen (pr.; cmdr. of 1000), 251+; see also Čigü Güregen

Č̈lgetei (pr.; cmdr. of 1000), 202; see also Čilgütei (?)

Da'aritai (pr.; uncle of Temüj̆in), 154; see also Dāritai

Daiduqul Soqor (pr.; chief of the Tumat people), 240

Dalan Baljut (pl.), 129, 201, 218

Dalan Nemürges (pl.), 153+, 173, 175, 205

Daqai (pr.; of the Suldus; cmdr. of 1000), 126; see also Taki, Taqai

Darbai (pr.; an ambassador of the Ui'ut), 238

Da'un (pr.; cmdr. of 1000), 202

Dayir (pr.; cmdr. of 1000), 202

Dayir (name of a gelding, 'Bay'), $\mathbf{3}$

Dayir Usun (pr.; of the U'as Merkit), 102, 105, 109, 111, 117+, 197+; see also Three Merkit

Dāritai (pr.; $4^{\text {th }}$ son of Bartan Ba'atur; uncle of Temüjin), 142, 153, 242; also Dāritai Otčigin, 50, 54, 56+, 122; see also Da'aritai

Degei (pr.; of the Besüt; a shepherd; cmdr. of 1000), 120, 124+, 202, 210, 216, 222, 243

Dei Sečen (pr.; of the Onggirat; father-in-law of Temüjuin), 61, 62+, (63), 65, 66, 69+, 94+

Deli'ün Boldaq (pl.; 'Deli'ün Hill'), 59, 97, 211

Dersüt (pl.), 150

Didik Saqal (pl.), 188+

Dobun Mergen (pr.; a son of Toroqolȳin; husband of Alan Qo'a), 3, 5+, $6+, 7,9,10,11,12,13+, 14,15,16,17,18$

Dolo'adai (pr.; cmdr. of 1000), 202

Dolo'an Bolda'ut (pl.; 'Seven Hills'), 136; also Dolo'an Boldaq, 282 
Dolonggir (cl.), 260

Dongqayit (cl.; of the Kereyit), 171, 208; see also Olon Dongqayit

Doqoladai (pr.; a son of Način Ba'atur), 46

Doqolqu (pr.; of the Mangqut), 210, 281; also Doqolqu Čerbi, 120, 124,

191, 226, 227, 234

Dori Buqa (pr.; cmdr. of 1000), 202

Dödei (pr.; cmdr. of dayguards; palace supervisor), 210; also Dödei Čerbi, 124, 191, 193+, 226, 227, 234+

Dörbei (pr.; of the Dörbet), 240; also Dörbei Doqšin, 240, 261

Dörben (peo.), 11, 120, 141+, 196; also plural Dörbet, 240, 261

Döregene (pr.; a wife of Qudu; given by Činggis Qan to Ögödei, and became regent of the Empire [1241-46] after the latter's death; mother of Güyük), 198+. Also Nai-ma-chen, Töregene

Dörmegei (pl.), 267. Also Ling-chou

Du'a Soqor (pr.; a son of Toroqoljin; had four sons), 3, 4, 5+, 11+

Dungčang (pl.; a city taken by J̌ebe; error for Dungging), 247+, 248

Duta'ut Tatar (cl.), 153+

Ebegei (pr.; mother-in-law of Sača Beki of the Jürkin), 130+

Ebügejin (pr.), 166+

Eder Altai Confluence (pl; at the Eder River), 161, 177

Ejil (rv.), 274; see also Adil, Idil. Also Volga

Eke Stream (rv.), 257

Ekhirit-Buriat (cl.): see Buriats

El Qutur (pr.; a younger brother of Ong Qan), 152

Elčidei (pr.): see Alčidai [of the J̌alayir]

Elder Brother the Ba'arin (pr.), 216; see also Ba'aridai

Eljidei (pr.): see Alčidai [of the J̌alayir]

Elǰigidei (pr.; cmdr.-in-chief of the Guard), 275, 278; also Eljigedei, 229

Enegen Güiletü (pl.), 142

Erdemtï Barula (cl.), 46

Erdis River (rv.), 198+; also Erdiš, 198, 207, 264. Also Irtysh

Erge Qara (pr.), 177; see also Erke Qara

Ergüne River (rv.), 141+, 144+, 182

Eriǰe'ü (pl.; a city of the Hsia Hsia), 265. Also Hsi-liang

Eriqaya (pl.; a city of the Hsia Hsia), 265. Also Chung-hsing (fu)

Erke Qara (pr.; younger brother of Ong Qan), 151, 177+; see also Erge Qara

Father Mönglik (pr.; of the Qongqotat), 69, 130+, 168+, 202, 204+, 244,

245+, 246+ ; see also Mönglik

Fu-chou (pl.): see Vuǰu

Gan River (rv.): see Kan River

Genghis Khan: see Činggis Qa'an 
Geniges (cl.), 47, 122, 210+

Geügi (pr.; cmdr. of 1000), 202

Ge'ün Stream (rv.), 257

Girma'u (pr.; $2^{\text {nd }}$ son of Qutula Qa'an), 51

Gobi (des.): see Čöl

Gungðu (pr.; = Kung-chu 'princess'; personal name Ch'i-kuo [RSH 2.899]), 248

Gurganj (pl.): see Örünggeči, Ürünggeči

Güčü (pr.; foundling; of the Merkit; cmdr. of 1000), 138, 202, 214, 243, 244; see also Küčü

Güčügür (cl.), 177

Güčügür (pr.; of the Besüt; brother of Degei; cmdr. of 1000), 124, 202, 223+; see also Küčügür

Güčülük (pr.; of the Naiman; son of Tayang Qan), 194, 196, 237; also Güčülük Qa'an, 198; Güčülük Qan 194+, 198, 202, 137. Also Küčlüg Güčü'üt Naiman (cl.), 141, 158

Gür Qan (pr.; brother of Qurčaqus; also a title, 'Universal Ruler'), 150, $177+$

Gürbesü (pr.; mother of Tayang Qan), 189+, 194, 196

Gürelgü Mountains (mt.), 89, 94, 122, 129, 141. Also Gürölgü Mountains

Gürin Ba'atur (pr.), 160. Also Gürün Bayatur

Gürölgü Mountains (mt.): see Gürelgü Mountains

Gürün Bayatur (pr.): see Gürin Ba'atur

Güsen Daril (pl.; seemingly = Kucha [pl].+Tarim [rv.]), 263

Güse'ür Na'ur (lk.): see Lake Güse'ür

Gü’ün Qo'a (pr.), 206; also Gü'ün U'a 137+

Güyigünek Ba'atur (pr.), 247

Güyük (pr.; son and successor of Ögödei), 270+, 274, 275+, 276+, 277+

Hariltu Na'ur (lk.): see Lake Hariltu

Harqasun (pr.; son of Elǰigidei), 275, 276+, 277

Herat (pl.): see Iru

Herirud (rv.; the Harīrūd, south of Herat): see Čoqčaran

Hindus (peo.; pl.), 261, 264+

Ho-hsi-wu (pl.): see Qosivu

Ho-lan Mountains (mt.): see Alašai

Hoqatur (pr.): see Oqotur

Horqudaq (pr.; cmdr. of quiverbearers), 225, 278

Höbögetür (pr.; a general of the Kitat), 251+

Hö'elün (pr.; bride of Čiledü of the Merkit; wife of Yisügei; mother of

Temüjüin), 55, 72, 102; see also Lady Hö'elün, Mother Hö'elün

Hökörtü Valley (pl.), 115

Hsi Hsia (peo.; Tang'ut state [RSH 1.550]): see Tang'ut

Hsi-liang (pl.): see Eriǰe'ü

Hsi Liao (peo.): see Qara Kidat. Also Western Liao in RSH 1.521, 553 
Hsiang-tsung [of Hsi Hsia] (pr.): see Burqan Qan

Hsüan-tsung [of Chin] (pr.): see Altan Qan [Hsüan-tsung]

Hsüeh-shan (mt.): see Časutu Mountain

Huǰa'ur Üjin (pr.; a dau. of Ong Qan; wife of Toqto'a of the Merkit), 177 Hula'an Burqat (pl.), 170+, 173

Hula'an Qut (mt.), 163, 177; also Hula'anu'ut Bolda'ut (plurals), 177

Huliyatu Subčit (pl.), 115

Hulun Nōr (lk.): see Lake Kölen

Hungarians (peo.): see Kerel, Majar

Hüle'üt Turas (pl.): see Ülengüt Turas

Hünegen Daba'an (pl.; 'Fox Pass'), 247

Hüsün (pr.; cmdr. of 1000), 202

I-la P'u-a (pr.): see Ile

Ibaqa (pr.), 208+; also Ibaqa Beki, 186, 208

Ibir Sibir (peo.): see Šibir

Idil (rv.), 262; see also Adil, Ejil. Also Volga

Idoqudai (pr.; cmdr. of 1000), 243; also Iduqadai (pr.), 202

Idürgen (pr.; a messenger of Ong Qan), 177; see also Itürgen

Ikires (peo.), 120, 129, 141+, 202

Ile (pr.; a general of the Kitat), 251+

Ilqaltun Beki/Begi (pr.): see Al Altun

Iluqu (pr.; leader of the Tang'ut), 267+; also Iluqu Burqan, 250, 267+,

268; Iluqu Burqan Šidurqu, 267. See also Burqan, Burqan Qan

Ilüge (pr.; cmdr. of 1000), 243; also Ilügei, 202, 226

Inalči (pr.; son of Quduqa Beki of the Oyirat), 239+

Inanča Bilge Qan (pr.; of the Naiman), 177+, 189, 194; also Inanča Qan,

151+

Indus (rv.): see Šin River

Irtysh (rv.): see Erdis River. Also Black Irtysh, Erdiš

Iru (pl.), 258, 259, 261. Also Herat

Isebür (pl.), 258, 259

Itürgen (pr.), 184+; see also Idürgen

Jui-tsung: see Tolui

Jurchens (peo.): see Jürčet; and RSH 2.889, 893

J̌adaradai (pr.; son of the woman seized by Bodončar), 40; see also J̌ăiradai

J̌adaran (cl.), 40+, 122, 129, 196, 223; see also J̌ăirat

J̌ăiradai (pr.), 40; see also J̆adaradai

J̌ăirat (cl.; plural of J̌ăiran), 141

Jalaldin Soltan (pr.), 257+, 264+; see also Soltan, the; Sultan, the. Also J̌alāl al-Dīn, Muḥammad Šāh of Khwārazm

J̌alama (mt.): see Mount J̌alama 
J̌alayir (peo.), 120+, 137, 244, 257, 264

J̌alayirtai Qorči (pr.), 274

J̌alāl al-Dīn (pr.): see J̌alaldin Soltan; Soltan, the; Sultan, the

J̌ali Buqa (pr.), 58; also J̌alin Buqa, 141

J̌aliyar (peo.): see J̌alayir

J̌amuqa (pr.; son of Qara Qada'an of the Jay̆irat; sworn friend of

Temuijin ), 40, 104+, 105+, 106, 107+, 108+, 110, 113+, 115+, 116+,

$117+, 118+, 119,121+, 122+, 125,127+, 128,129+, 130+, 141+$,

$142+, 144+, 160+, 166+, 167,170+, 174,179,181,194,196+, 200+$,

201+, 218, 246; rupture of relations with Činggis Qan, 127, 200, 201

J̌anggi (pr.), 277+

Jaqa Gambu (pr.; younger brother of Tayang/Ong Qan of the Kereyit),

$107,108+, 142,150+, 152,186+, 208+$

J̌aqut (peo.), 281

J̌arči'udai (pr.; of the Uriangqai; father of Sübe'etei and J̌elme), 97+; see also Old J̌arči'udai

J̌arči'ut (cl.), 38

J̌au Gon (pr.; Sung Emperor), 251+

J̌ayaq (rv.), 262, 270, 274. Also Ural

Jebe (pr.; of the Tayiči'ut; cmdr. of 1000; one of the 'four hounds'), 146,

$147+, 153,193,195,202,209+, 221,237,247+, 248,251+, 252$, 257+, 272; see also Jirqo'adai

J̌ebke (pr.; son of Telegetü Bayan of the J̌alayir; cmdr. of 1000), 137+, 202, 243, 244

Jedei (pr.; of the Mangqut; elder brother of Doqolqu; cmdr. of 1000); see also J̌etei

J̌eder (pr.; cmdr. of 1000), 202

J̌egei Qongdaqor (pr.), 120; see also Yegei Qongtaqar; also J̌egei Qongtoqar

J̌egü (pr.; cmdr. of company of dayguards), 278

J̌eje'er Heights (mt.), 166, 185

Jelme (pr.; of the Uriangqai; elder brother of Sübe'etei; cmdr. of 1000; one of the 'Four Hounds'), 97+, 99, 103, 120+, 125, 145+, 195, 202, 209+, 211+, 214+, 225; also J̌elme Qo'a, 170

J̌er Gorge pass (pl.), 185

J̌erene Gorge (pl.), 129+, 201

J̌etei (pr.), 120, 124, 202, 214+; see also J̌edei

J̌e'üredei (pr.; a son of Bodončar), $\mathbf{4 3 + , 4 4}$

J̌e'üret (cl.), 44, 183; also J̌e'üreyit, 44

Jirgin (cl.), 170+, 171+, 185+, 186+, 187, 208; relation of to the Jürkin, RSH 2.674-5

J̌irqo'adai (pr.), 147, 257; see also J̌ebe

Jirqo'an (pr.; of the Oronar), 120

J̌čci (pr.; eldest son of Temüj̆in), 165, 210, 239+, 242+, 243, 254+, 255+, 258+, 260+ 
J̌oči (pr.; son of Qutula), $\mathbf{5 1}$

J̌oči Darmala (pr.), 128+; see also Čoči Darmala

J̌oči Qasar (pr.; 2 ${ }^{\text {nd }}$ son of Yisügei Ba'atur), 60, 195; see also Qasar

J̌orqal Qun (mt.), 177

J̌osotu Boro (name of a horse of Činggis Qan), 265+

Jubqan (pr.; an ambassador of Činggis Qan to the Sung court), 251

Jungdu (pl.), 247, 248+, 251, 252+, 263, 273; see also Beiging. Also

Chung-tu, Peking

J̌ungsai (pr.; cmdr. of 1000), 243; see also J̌ungšoi

Jungso (pr.; of the Noyakin), 120

J̌ungšoi (pr.; cmdr. of 1000), 202; see also J̌ungsai

Jürčedei (pr.), 130, 171+, 176+, 185+, 202, 208+, 209, 226, 253; see also Uncle J̌ürčedei

J̌ürčet (peo.; plural of J̌ürčen; = Kitat), 247, 248, 253; see also Jurchens

Jürčet (peo.; Eastern Jurchens of Manchuria), 274; see RSH 2.1010

J̌ürki (cl.): see Jü̈rkin, Yürki

Jürkin (cl.), 122, 130, 131, 132, 133+, 136+, 137+, 138, 139+, 140; relation of to the Jirgin, RSH 2.674-5

Jüyin (peo.; of the Qara Kidat/Kitat), 247, 248, 266

Kan River (rv.; or Ken [RSH 3.89-90]), 141+. Also Gan River

Karakorum: see Qara Qorum

Kashgar (pl.): see Kisqar (error for Kišqar)

Kashmir (pl.; also Kašmīr): see Kešimir

Keltegei Qada (pl.), 175, 191, 192. Also Mount Keltegei

Kelüren River (rv.), 94+, 96, 98, 107, 136, 142, 151, 177, 183+, 193, 269, 282. Also Kerulen River

Ken River (rv.): see Kan River

Kerel (peo.), 262 (where wrongly written Raral), 270; see also Majar. Also Hungarians

Kereyit (peo.), 96, 104, 105, 126, 134, 150+, 171, 172, 174, 185, 186,

187+, 200, 208+, 214, 242; see also Ongqojit Kereyit

Kerulen River/Kerülen River (rv.): see Kelüren River

Kesdim (peo.), 239

Kešimir (peo.), 262, 270. Also Kashmir

Kete (pr.; cmdr. of 1000), 120, 243

Ketei (pr.; cmdr. of 1000), 202

Khalkha River (rv.): see Qalqa River

Khan-melik (pr.): see Qan Melik

Khangai Mountains (mt.): see Qangqai Mountains

Khentei Khan (mt.): see Burqan Qaldun

Khorasan (pl.), 259

Khotan (pl.): see Udan

Khwārazmian empire: see Qurumši 
Kibčaq (peo.), 275; also plural Kibča'ut, 262, 270, 274, 277+; see also Kimča'ut. Also Comans

Kičil Baš (lk.), 177; see also Lake Kišil Baš

Kidat (peo.): see Kitat

Kiev (pl.): see Kiwa Menkermen, Mankerman Kiwa, Menkermen Keyibe Kilqo (rv.), 105, 109+

Kimča'ut (peo.), 198; see also Kibčaq

Kimurqa Stream (rv.), 88+, 107, 122+

Kinggiyadai (pr.; cmdr. of 1000), 120, 202

Kiratai (pr.; a messenger of Činggis Qan to Senggüm), 168+

Kirghiz (peo.): see Kirgisut, Tümen Kirgisut

Kirgisut (peo.; plural of Kirgis), 239+; see also Tümen Kirgisut

Kisqar (pl.; error for Kišqar = Kashgar), 263

Kišil Baš (lk.; tu. 'red head'): see Lake Kišil Baš

Kišiliq (pr.; herdsman of Yeke Čeren; cmdr. of 1000), 51, 169+, 170, 187+, 202, 219

Kitans (peo.): see Kitat

Kitat (peo.; plural of Kitan), 53, 132, 247+, 250+, 251+, 263+, 266+, 271+, 272+; see also Altan Qan, Jurchet, Qara Kidat. And see RSH $2.889,893$

Kiwa Menkermen (pl.), 262; see also Mankerman Kiwa, Menkermen Keyibe. Also Kiev

Kiyan (cl.): see Kiyat

Kiyat (cl.; plural of Kiyan), 63

Kobdo River (rv.): see Soqoq Usun

Koreans (peo.): see Solangqas

Köde'e Aral (pl.), 282; also Köde'ü Aral, 269; Ködö'e Aral 136

Köke Čos (pr.), 243; see also Kökö Čos

Kökö (pr.; cmdr. of 1000), 202

Kökö Čos (pr.; of the Ba'arin; cmdr. of 1000; adviser to Ča'adai), 120, 202, 210+, 216, 254; see also Köke Čos

Kökö Na'ur (lk.; 'Blue Lake'), 89, 122

Kököčü (pr; foundling; cmdr. of 1000), 119, 138, 202, 214, 243, 244

Kököčü (pr.; Senggüm's equerry), 188+

Kököčü Kirsa'an (pr.; son of slave Sübegei), 180+

Kököčü Teb Tenggeri (pr.; middle son of Mönglik of the Qongqotat), 244; see also Teb Tenggeri

Köksegü Sabraq (pr.; of the Naiman), 163; also Kökse'ü Sabraq, 159,

$162,163,177+, 189,190+, 194$

Köl Barquǰin Lowland (pl.), 8; see also Barqujin Lowland

Kölen, Kölen Na'ur (lk.): see Lake Kölen

Kötön Baraqa (pr.), 58

Köyiten (pl.), 143, 147

Kucha (pl.): see Güsen Daril

Küčlüg (pr.; Naiman prince [RSH 2.963]): see Güčülük 
Küčü (pr.), 114; see also Güčü

Küčügür (pr.), 120; see also Güčügür

Labalqa (pr.; cmdr. of company of quiverbearers), 278; also Lablaqa, 225

Lady Börte (pr.; wife of Temüjuin), 94+, 99, 100, 104, 105, 110+, 111,

118, 119, 245+; see also Börte

Lady Hö'elün (pr.; mother of Temüjuin), 55, 56+, 59, 70+, 72, 73, 74+,

130+; see also Hö'elün, Mother Hö'elün

Lake Baikal (lk.): see Tenggis

Lake Baljuna (lk.), 182, 183, 183+, 208+

Lake Buyur (lk.), 53, 176. Also Buir Nōr

Lake Güse'ür (lk.), 151, 177. Also Güse'ür Na'ur

Lake Hariltu (lk.), 136

Lake Hulun (lk.): see Lake Kölen

Lake Kišil Baš (lk.), 158; see also Kičil Baš

Lake Kölen (lk.), 53. Also Hulun Nōr, Kölen Nau'ur, Lake Hulun

Li An-ch'üan (pr.; of Hsi Hsia): see Burqan Qan

Li Hsien (pr.; of Hsi Hsia): see Burqan Qan

Li Tsun-hsü (pr.; of Hsi Hsia): see Burqan Qan

Ling-chou (pl.): see Dörmegei

Lung-hu t'ai (pl.): see Šira Dektür

Ma'aliq Baya'ut (cl.), 15, 18; see also Baya'ut

Madasari (pl.), 261. Also Mazandaran (RSH 2.957)

Magas (pl.): see Meget, Meket

Magyars (peo.): see Majar

Maḥmūd Yalavač (pr.): see Yalawači

Maǰar (peo.), 270; also Majaarat, 262. Also Hungarians, Magyars

Malik Xān Amīn al-Mulk (pr.): see Qan Melik

Mangqut (peo.), 46, 120, 130+, 170+, 171+, 175, 195, 209

Mangquai (pr.; a cmdr. in charge of reserve [of dayguards]), 278

Mangquai (pr.; son of Način Ba'atur), 46

Mankerman Kiwa (pl.; = Menkermen), 274; see also Kiwa Menkermen, Menkermen Keyibe. Also Kiev

Maqa Tudun (pr.): see Menen Tudun

Maral (pr.; cmdr. of 1000), 202

Maru (pl.), 261. Also Merv

Masqut (pr.; Mas'ūd Beg; son of Yalawači), 263+

Ma'u Heights (mt.), 170+, 173. Also Mau Heights

Mazandaran (pl.): see Madasari

Meget (pl.), 274, 275; see also Meket. Also Magas

Megetü (pr.; cmdr. of 1000), 202

Megüjin (pr.), 133; also Megüujin Se'ültü, 133+, 134+

Meket (pl.), 270; see also Meget 
Menen Ba'arin (cl.), 41, 120

Menen Tudun (pr.; son of Qabiči Ba'atur), 45+

Menkermen Keyibe (pl.; Menkermen); 270; see also Kiwa Menkermen, Mankerman Kiwa. Also Kiev

Merkit (peo.), 54, 102+, 103+, 104+, 105, 110+, 111+, 112, 113, 115,

$117,138,141,142,144,145,150,152+, 157,162,169+, 177+, 198+$, 200, 208+, 219+, 236, 254; see also Qa'at Merkit, Qo'as Merkit, Uduyit Merkit, U'as Merkit

Merv (pl.): see Maru

Moči Bedü'ün (pr.; of the Dörbet; joint cmdr. of 1000 with Qubilai),

120; see also Bedü'ün

Mojiu (pl.), 248. See RSH 2.900

Mongrol (peo.): see Mongols

Mongyolȳin Гooa (pr.): see Mongqolǰin Qo'a

Mongols/Mongqol (peo.), 52+, 57+, 108, 126, 142, 174+, 187, 189+, 190+, 193+, 194+, 196+, 202, 248+, 265, 266, 272. Also Mongyol

Mongqolǰin Qo'a (pr.), 3. Also Mongrolj̄in Гooa

Moroqa (pr.; cmdr. of 1000), 202

Mother Alan (pr.), 76; see also Alan Qo'a

Mother Earth, 113, 255

Mother Hö'elün (pr.), 61, 93, 98, 99+, 102, 111, 114, 118, 119+, 135+,

137, 138+, 166, 195+; see also Hö'elün, Lady Hö'elün

Mother Nomolun (pr.), 46. Also Nomolun

Mother Onan (rv.), 75; see also Onan River, Onon

Mother Qo'aqčin (pr.), 103; see also Old Qo'aqčin, Qo'aqčin

Mother Sučigil/Suǰigil (pr.), 60

Mother Sun, 238

Mount Burqan (mt.), 100, 101, 103; also Mount Burqan Qaldun, 1, 103+,

106, 107+, 111, 115, 199, 205, 211; see also Burqan, Burqan Qaldun

Mount Čekčer (mt.), 61, 67, 94, 142

Mount Čiqurqu (mt.), 61, 94, 142+,

Mount Düyiren (mt.), 28

Mount J̌alama (mt.), 128

Mount Keltegei (mt.): see Keltegei Qada (RSH 1.633-34)

Mount Qangqarqan (mt.), 193+

Mount Qara Jirügen (mt.), 89, 122

Möngge (pr.), 270+; also Mönggei, 277+; see also Möngke

Mönggetü (pr.), 270

Mönggetü Kiyan (pr.), 50, 120, 213

Mönggü'ür (pr.; cmdr. of 1000), 202; see also Möngke'ür

Möngke (pr.; eldest son of Tolui ), 243, 274; see also Möngge/Mönggei

Möngke (pr.; cmdr. for Ča'adai), 243; also Möngkö Qalj̆a, 202

Möngke'ür (pr.), 243; see also Mönggü'ür

Mönglik (pr.), 68+, 69; see also Father Mönglik

Muhammad Šāh (pr.): see Khwārazm; Qurumši; Soltan, the; Sultan, the 
Mulqalqu (pr.; joint cmdr. of a thousand with Güčügür), 122, 124, 223+ Muqali (pr.; son of Gü'ün Ü'a of the J̌alayir; brother of Buqa; one of the 'four steeds'), 137, 156, 163, 177, 202, 203+, 205, 206+, 209, 210 , 220, 226, 240, 242+, 254+, 260, 266+; also Muqali Gui Ong, 202, 206 Müge (pr.; cmdr. of 1000), 202

Mülke Totaq (pr.; of the Ikires), 129

Mürüče Se'ül (pl.), 177

Način Ba'atur (pr.; a son of Menen Tudum), 45, 46

Nai-ma-chen (pr.; = Naimajin 'The Naiman' [RSH 2.729]): see Döregene

Naiman (peo.; some were Nestorian Christians), 141, 142, 144, 151, $152+, 159,160+, 161,163,166,177+, 188,189,190+, 192,193+$, 195+, 196+, 198+, 200+, 202, 208+, 237; see also Güčü'üt Naiman

Namging (pl.; = Nan-ching, 'Southern Capital', of the Chin), 251, 253, 273

Naqu Bayan (pr.; 'Naqu the Rich'; father of Bo'orču), 90, 92+, 93+, 205

Naqu (mt.), 196; also Naqu Cliff, 195+, 196

Naratu Šitü'en (pl.), 133, 135

Narin Ke'en (pr.; son of Yeke Čeren), 169+

Narin To'oril (pr.; son of Čaqa'an Qo'a), 218; see also To'oril [Narin To'oril]

Na'u (rv.), 253

Naya'a (pr.; a son of Širgü'etü of the Ničügüt Ba'arin; cmdr. of 1000, 10,000), 149+, 197+, 202, 220+; also Naya'a Bilji’ur, 220, Naya'a Noyan (pr.), 197+

Negüs (peo.), 218+; see also Činōs, Ne'üs

Nekün Taiši (pr.; a son of Bartan Ba'atur; elder brother of Yisügei), 50,

$54,56,122,130,179$

Nekün Usun (pl.), 188+

Ne'üs (peo.), 120, 129; see also Negüs

Ničügüt Ba'arin (cl.), 149

Nilqa Senggüm (pr.; son of Ong Qan of the Kereyit; for the two names see RSH 1.589-90), 165, 166+, 167+; see also Senggüm

Nomolun/Nomolun Eke (pr.; mother of Qaidu): see Mother Nomolun

Noyagidai (pr.; son of Qačin), 46

Noyakin (peo./pr.), 46, 120, 166+

Olar Güregen (pr.; cmdr. of 1000), 202

Old Čaraqa (pr.), 68, 72+, 73+

Old J̌arči'udai (pr.; of the Uriangqai), 97, 211; see also Jarči'udai

Old Qo'aqčin (pr.; maidservant of Mother Hö'elün), 98, 100+, 101+; see also Qo'aqčin, Mother Qo'aqčin

Old Širgōtü (pr.; of the Ničigüt Ba'arin), 220+; also Old Širgü'etü, 149+; see also Šrgü'etü 
Old Üsün (pr.), 120, 210, 216+; given rank of beki, 216; see also Üsün

Oldaqar Qorči (pr.), 271

Olon Dongqayit (cl.), 150, 170+, 171+, 187; see also Dongqayit

Olqunu'ut (cl.; a clan of the Onggirat $\sim$ Qonggirat [RSH 1.325]), 54, 61, 62, 120; see also Onggirat

Onan River (rv.), 1, 24, 30, 32, 50, 54, 56, 57, 59, 72, 74, 75, 81+, 82, 84, 88, 97, 106+, 108, 116, 130, 136, 144+, 202, 211; see also Mother Onan, Onon

Ong Qan (pr.; To'oril Qan of the Kereyit), 96+, 134+, 141+, 142+, 144, $150+, 151+, 152+, 157+, 158,159+, 160+, 161,162+, 163+, 164+$, $167+, 168,170+, 171,174+, 177+, 178+, 180,181,183+, 184+$, 185+, 186, 187, 188+, 189+, 200, 204; also Ong Qa'an, 150; see also To'oril, To'oril Ong Qan

Ongging Čingsang [Wan-yen Fu-hsing] (pr.; 'Right Chancellor'), 248+. Also Wan-yen Fu-hsing

Ongging Čingsang [Wan-yen Hsiang] (pr.; 'Right Chancellor'), 132+, 133+, 134+. Also Wan-yen Hsiang

Onggiran (pr.; cmdr. of 1000), 202

Onggirat (peo.), 61, 64+, 94, 141+, 176+, 177, 196, 202 see also Olqunu'ut. Also Qonggirat

Ongqojit Kereyit (cl.), 187

Onon (rv.), 129+; see also Onan River

Oqda Bo'ol (pr.; 'slave Oqda'; ancestor of To'oril), 180+

Oqotur (pr.), 270

Or Bend of the Qalqa (pl.), 175, 191, 192

Orkhon (rv.): see Orqon

Oronar (cl.), 47, 120

Oronartai (pr.; cmdr. of 1000), 202

Orqon (rv.), 105, 195; also Orqan, 115. Also Orkhon

Orusut (peo.; plural of Orus [= Русъ $]$, 'Russians'), 262, 270, 274, 275, 277+. Also Rus, Russians

Ossets (peo.): see Asut

Otčigin (pr.; Temüge, youngest brother of Temüjuin), 195, 242+, 243, 244, 245+, 255, 281; also Otčigin Noyan, 190, 195, 245+, 257, 269, 280; see also Temüge

Otrar (pl.): see Udarar

Oxus River: see Amui Müren

Oyirat (peo.), 141, 142, 144, 239+; see also Tümen Oyirat

Ögele Čerbi (pr.; younger brother of Bo'orču), 191, 226+; see also Ögöle Ögödei (pr.; $3^{\text {rd }}$ son and successor of Činggis Qan; 1186-1241), 214+, 242, 243, 255+, 258+, 260+, 269+; also Ögödei Qa'an (pr.), 198, 269+, 270+, 271, 272+, 273, 274+, 275, 278, 279+, 280, 281; see also Öködei. Note also RSH 1.624, 3.3-5, 130-33, 136-37, 224, 225 
Ögöle (pr.; younger brother of Bo'orču; joint cmdr. of dayguards), 234; also Ögöle Čerbi, 191, 230; Ögölei Čerbi, 124; Ögölen Čerbi, 120; see also Ögele Čerbi

Ökin Barqaq (pr.), 48, 49, 139+, 140; see also Barqaq

Öködei (pr.; $3^{\text {rd }}$ son and successor of Činggis Qan), 172+, 173+; see also Ögödei

Ölegei Spring (pl.), 128

Önggür (pr.; son of Mönggetü Kiyan; cmdr. of 1000), 120, 124, 202, 213+, 252+; also Önggür Baurči/Ba'urči ('steward Önggür' of the Baya'ut), 124, 213, 252

Önggüt (peo.; of Turkic origin; converted to Nestorian Christianity [RSH 2.656] ), 182, 190, 202, 239

Örbei (pr.; a wife of Ambaqai Qan), 70+, 71

Örebek Digin (pr.; a leader of the Kirgisut), 239

Örünggeči (pl.), 260+; see also Ürünggeči. Also Gurganj

Ötegen (cl.), 260

Parwan/Parvān (pl.): see Baru'an Plain

Peking (pl.): see Chung-tu, Jungdu

People of the Forest (peo.), 202, 207+, 239+, 241; see also Kesdim, Kirgisut, Oyirat, Qabqanas, Qori Tumat, Telengüt, Tö'eles, Tö’ölös, Tumat. Note also RSH 3.117

'people of the nine tongues' (peo.), 245+

Prince Tolui (pr.), 272+; see also Tolui

Qa'at Merkit (cl.), 102, 105, 106, 111

Qa'atai Darmala (pr.; of the Qa'at Merkit), 102, 105, 111, 112; see also Three Merkit, the

Qabiči Ba'atur (pr.), 43, 45; see also Barim Ši'iratu Qabiči

Qabqanas (peo.), 239

Qabturqas (cl.), 47

Qabul Qa'an (pr.), 48+, 52+, 53; also Qabul Qan, 139+, 140

Qača'uratu Subčit (pl.), 115

Qači Külük (pr.; 'hero Qači'; $1^{\text {st }}$ son of Menen Tudun), 45, 46

Qačin (pr.; $2^{\text {nd }}$ son of Menen Tudun), 45, 46

Qačir Usun (rv.; 'Mule Water'), 194, 195

Qači'u (pr.; $3^{\text {rd }}$ son of Menen Tudun), 45, 46

Qači'un (pr.; $5^{\text {th }}$ son of Menen Tudun), 45, 46

Qači'un (pr.; $3^{\text {rd }}$ son of Yisügei Ba'atur; brother of Činggis Qan), 60, 79, 99, 244; also Qači’un Elči, 60

Qači'un (pr.; chief of the Dörben), 181; probably = Qači'un Beki, Qajił'un Beki

Qači'un Beki (pr), 166+; see also Qajui'un Beki. Probably = Qači'un [chief of the Dörben] 
Qači'un Toqura'un (pr.; of the J̌alayir), 120, 124; see also Qaraqai Toqura'un, Qaraldai Toqura'un

Qačula (pr.; $4^{\text {th }}$ son of Menen Tudun), 45, 46

Qada (pr.; a general of the Kitat), 251+, 252+

Qada (pr.; husband of Qoluiqan, q.v.)

Qada'an (pr.; of the Tarqut; cmdr. of 1000), 202, 278+

Qada'an (pr.; dau. of Sorqan Šira; sister of Čimbai and Čila'un), 85, $146+, 219$

Qada'an (pr.; $6^{\text {th }}$ son of Qabul Qan), 48, 51, $\mathbf{5 7}$

Qada'an Daldurqan (pr.; a steward), 120, 124, 174+

Qada'an Taiši (pr.; son and Ambaqai Qan), 53

Qadagin (peo.), 131, 141+; see also Qatagin

Qadai (pr.; cmdr. of nightguards), 278+; also Qadai Güregen (cmdr. of 1000), 202

Qadaq (pr.; of the Jirgin), 170; also Qadaq Ba'atur, 185+

Qadingliq/Qadiqliq Ridge (pl.; tu. Qadïnglï 'having birch trees'), 177

Qaidu (pr.; son of Qači Külük), 46, 47

Qaidu (pr.; grandson of Ögödei)

Qaji'un Beki (pr.), 141; see also Qači'un [chief of the Dörben], Qači'un Beki

Qal (pr.; $2^{\text {nd }}$ son of Toqto'a Beki of the Merkit), 198 (written Qat), 199+

Qalaqaljit Sands (pl.), 170, 200, 208, 214

Qaldun Burqan (mt.), 103, 112; also Qaldun, 103; see also Burqan Qaldun

Qalibai Soltan, the (pr.), 260+, 270. Also al-Mustanșir

Qali'udar (pr.; of the J̌e'üriyet), 183+, 184+, 185,

Qalqa River (rv.), 175, 176, 191, 192; also Qalqa, 175+, 208. Also Khalkha River, Xalxyn Gol

Qan Melik (pr.), 257+, 264+. Also Amīn al-Mulk, Malik Xān Amīn alMulk

Qanglin (peo.; tu. Qanglii), 198, 262, 270, 274

Qangqai Mountains (mt.), 194. Also Khangai Mountains

Qangqarqan (mt.): see Mount Qangqarqan

Qangqas (peo.), 239

Qara Jirügen (mt.): see Mount Qara Jirügen

Qara Kidat (peo.), 151, 152+, 177, 198, 247; Jüyin of, 247, 266; also Qara Kitat, 248; Jüyin of, 248, 266. Also Kitat/Kitan, Qara Kitai. See Western Liao empire in Subject Index

Qara Qada'an (pr.; son of Büri Bulčiru), 40+

Qara Qorum (pl.; on the east bank of the Orqon River, in heartland of the ancient Turks [tu. 'Black Boulder']; capital of the Mongol Empire in the $13^{\text {th }}$ century), 273. Also Karakorum. Note also RSH 2.1004-07, 3.134-35

Qara Se'ül (rv.; 'Black Tail'), 159, 177

Qara Tün (pl.): see Black Forest by the Tu'ula River 
Qaračar (pr.; son of Suqu Sečen of the Barulas; cmdr. of 1000), 120, 202, 243

Qaradal Source (pl.), 197

Qaraǰi Steppe (pl.), 105

Qaraldai (pr.; $6^{\text {th }}$ son of Menen Tudun), 45, 46

Qaraldai Toqura'un (pr.; brother of Qači'un Toqura'un), 120, 124

Qaraqai Toqura'un (pr.; brother of Qači'un Toqura'un), 120; see also Qarqai Toqura'un

Qara'udar (pr.; cmdr. of nightguards), 278+

Qara'un Gorge (pl.), 150, 177+

Qara'un J̌idun (mt.), 183, 206

Qarču (pr.), 2, 3

Qardakin (peo.), 166; see also Qarta'at

Qargil Šira (pr.; of the Tatar), 214+

Qarlu'ut (peo.; plural of Qarluq), 198, 235+

Qarqai Toqura'un (pr.), 124; see also Qaraqai Toqura'un

Qarta'at (peo.), 166; see also Qardakin

Qasar (pr.; $2^{\text {nd }}$ son of Yisügei Ba'atur by Hö'elün), 60, 76+, 77+, 79, 90, 93, 96, 99, 104, 105+, 107, 124, 130+, 137, 161, 183+, 184+, 195, 242, 243, 244+, 245, 253+, 255; see also J̌oči Qasar

Qaši (pr.; a son of Čila'un Qayiči of the J̌alayir), 137

Qašin (pl.), 150, 177, 249+, 250; see also Tangut; and Hsi Hsia kingdom in Subject Index

Qat (pr.); in 198 erroneous writing for Qal

Qatagin (peo.), 42, 196; see also Qadagin

Qa'uran (pr.; cmdr. of 1000), 202

Qïpčaq (peo.); see Kibčaq/Kibča'ut, Kimča'ut

Qo'aqčin (pr.; old maidservant of Hö'elün), 110; see also Mother Qo'aqčin, Old Qo'aqčin

Qo'as Merkit (cl.), 197; see also U'as Merkit

Qodu (pr.): see Qudu, Qutu

Qodun Örčeng (pr.; of the Tayiči'ut), 141, 144; see also Qoton Örčeng

Qojin Beki (pr.; or Qočin Begi [RSH 1.597]; eldest dau. of Činggis Qan), 165

Qoluiqan (pr.; dim. form of the name Qolui; granddau. of Činggis Qan; wife of Qada), 239

Qonggirat (peo.): see Onggirat

Qongqai (pr.), 260+; also Qongqai Qorči, 260

Qongqortaqai (pr.; cmdr. of company of dayguards), 278; also Qongqortāi, 277+ $(\bar{a}<$ a a a $)$; and Qongqortai, 278

Qongqotan (cl.), 47, 120, 244+, 245+, 265; also plural Qongqotat, 68, 72, 73, 130

Qongtaqar (pr.; of the Dolonggir), 260+; also Qongtaqar Qorči, 260

Qorči (pr.; of the Ba'arin; cmdr. of 1000, 10,000), 120, 121+, 202, 207+, 241+; also Qorči Noyan, 241+ 
Qorčuqui Hill (mt.), 88

Qori Buqa (pr.), 59

Qori Qačar (pr; cmdr. of nightguards), 278+

Qori Sübeči (pr.; a Naiman chief ), 188+, 189, 194

Qori Šilemün Taiši (pr.; leader of Ong Qan's bodyguards), 170+, 171+; see also Quri Šilemün

Qori Tumat (cl.), 8+, 9+, 240; see also Tumat

Qoričar Mergen (pr.; 'Qoričar the wise'), 2+

Qoridai (pr.; of the Qorolas), 141

Qorij̄in Qatun (pr.; of the Jürkin; a wife of Sorqatu Jürki and mother of Sača Beki), 130, 132+, 136

Qorilar (cl.), 9

Qorilartai Mergen (pr.; of the Qori Tumad), 8+, 9+

Qorolas (peo.), 120, 141+; see also Qorulas

Qorqasun (pr.; cmdr. of 1000), 243; see also Qorqosun

Qorqonaq Valley/Qorqonaq Jubur (pl.), 57+, 104, 115, 116, 117, 201, 206,

Qorqosun (pr.), 202; see also Qorqasun

Qorulas (peo.), 182+; see also Qorolas

Qosivu (pl.; Chinese Ho-hsi-wu), 252

Qoton Örčeng (pr.), 148; see also Qodun Örčeng

Quba Qaya (mt.), 148, 151, 153

Qubilai (pr.; of the Barulas; cmdr. of 1000; one of the 'four hounds'),

120, 124, 153, 193, 195, 202, 209+, 235; also Qubilai Noyan, 235+

Qubilai Qa'an (pr.; son of Tolui and Berüde/Sorqartani Begi; ruled 126094)

Qučar (pr.; son of Nekün Taiši), 123, 127+, 142+, 153, 166+, 174, 179+, 180, 181, 246, 255+; also Qučar Beki, 122

Qudu (pr.; son of Toqto'a Beki of the Merkit), 177, 197, 198+, 199+; see also Qutu. Also Qodu

Quduqa (pr.; cmdr. of 1000), 143; also Quduqa Beki, 141, 142, 144, 239+, 241+

Quduqul Bend (pl.), 149; see also Qutuqul Bend

Qudus (pr.; of the Barulas; brother of Qubilai; cmdr. of 1000), 120, 202

Qudus Qalčan (pr.), 191

Qudu'udar (pr.; of the Tayiči'ut), 148

Qul Bari (pr.): see Qulbari

Qulan (pr.; $5^{\text {th }}$ son of Qabul Qa'an), 48; also Qulan Ba'atur, 51

Qulan Qatun (pr.; dau. of Dayir Usun of the Merkit), 197+, 257

Qulbari (pr.; a younger brother of Ong Qan of the Kereyit), 152; also Qulbari Quri, 177

Quldaqar Cliff (pl.), 117

Qum Šinggir (pl.; tu. 'Sand Promontory'), 158

Qunan (pr.; of the Geniges; cmdr. of 1000, 10,000), 122, 202, 210+, 216, 243 
Qunan (pr.; of the Tayiči’ut), 177

Qurban Telesüt (pl.), 177. Also Qurban Talasut

Qurčaqus (pr.; cmdr. of 1000), 202; also Qurčaqus Buyiruq Qan, 150, 152, 167, 177. Also Cyriacus

Quri Šilemün (pr.), 208; see also Qori Šilemün Taiši

Quril (pr.; cmdr. of 1000), 202

Qurumši (cl., peo.; = Persian Xvārazmī, ethnicon of Xvārazm), 263+. Also Khwārazmian empire

Qusutu Šitü'en (pl.), 133

Qutu (pr.; son of Toqto'a Beki of the Merkit), 141, 142, 144, 157, 162, 236; see also Qudu. Also Qodu

Qutu Moriči (pr.), 124

Qutula (pr.; $4^{\text {th }}$ son of Qabul Qa'an), 53, 57; also Qutula Qa'an, 48, 51; Qutula Qan (pr.), 122, 179, 206

Qutuqtai (pr.), 157

Qutuqtu Mönggür (pr.), 48, 50; also Qutuqtu Möngler, 140

Qutuqtu Yürki (pr.), 49; error for Sorqatu Yürki/Jüurki

Qutuqu (pr.; foundling; cmdr. of 1000), 252; see also Šigi Qutuqu

Qutuqul Bend (pl.), 149, 220; see also Quduqul Bend

Qu'určin (pr.), 136; also Qu'určin Qatun, 130, 132+

Quyildar (pr.; of the Mangqut; cmdr. of 1000; sworn friend of Činggis Qan), 171+, 175, 185+, 202, 208, 209, 217; also Quyildar Šečen, 171, 185

Raral (peo.): see Kerel

Rus/Russians (peo.): see Orusut

Sa'ari Steppe (pl.), 128, 161, 177, 193+, 197, 250. Also Sa'ari Ke'er

Sača (pr.; elder son of Sorqatu Jürki), 136+, 137, 179; also Sača Beki,

122, 123, 130+, 133, 136+; see also Seče Beki

Sali Qača'u (pr.; son of A'uǰam Boro'ul), 2+

Salji'ut (cl.), 42, 141+, 196

Samarkand (pl.): see Semisgab, Semisgen

Saqayit (peo.), 122

Saqšïn (peo.; of the lower Volga): see Sasut

Sariq Qun (pl.; tu. 'Yellow Cliff'), 237

Sartaq (peo.; Muslim; inhabitant of Turkestan [RSH 1.562, 3.93-95]),

182, 263; also plural Sarta'ul, 152, 177, 198, 254+, 256, 257+, 260, 263+, 264, 265

Sasut (peo.; plural of Sas, = Saxons [of Transylvania] or [?] Saqšïn of the lower Volga), 262; see also Sesüt

Sayiqan Töde'en (pr.), 167+

Seče Beki (pr.; elder son of Sorqatu Jürki), 49; see also Sača

Seče Domoq (pr.; of the J̌alayir), 120

Seče'ür (pr.; cmdr. of 1000), 202

Sečeyiken (pr.): see Čečeyigen 
Seči'ür (pr.; of the Qorolas), 120

Selengge (rv.; Selenga River), 105, 109, 110, 115, 144, 152, 162, 177, 219+

Sem Sečüle (pr.; $2^{\text {nd }}$ son of Tumbinai Sečen), $48+$

Sem Soči (pr.; son of Yeke Nidün), 2+

Semisgab (pl.), 257, 259+; error for Semisgen q.v.

Semisgen (pl.), 263; see also Semisgab. Also Samarkand

Senggüm (pr.; only son of Ong Qan of the Kereyit; sworn friend of Temüjin), 142+, 162, 163, 164+, 165+, 167+, 168+, 171+, 172, 174+, 177+, 181+, 185, 188+, 204, 208+; and conspiracy against Činggis Qan, 166-9; see also Nilqa Senggüm. (For origin of this name/title, see RSH 1.589-90, 3.57.)

Senggüm Bilge (pr.; son of Čaraqai Lingqu), 47+, 52

Senggür Stream (rv.), 89, 93, 94, 96, 122

Sergesüt (peo.), 270; also Serkesüt, 262. Also Čerkes, Circassians

Sesüt (peo.), 270, 274; see also Sasut

Seüse (pr.; Hsiao-ssu, 'Little Slave'; name given to Altan Qan by Ögödei

Qa'an; see RSH 2.1001-02), 273; see also Altan Qan [Ai-tsung]

Shen-tsung [of Hsi Hsia] (pr.; ruled 1211-23). Also Burqan Qan, Li Tsun-Hsü

Shih-tsu [of Yüan] (pr.): see Qubilai Qa'an

Shou-hsü [of Chin] (pr.): see Altan Qan (Ai-tsung)

Sibir (peo.): see Šibir

Sisten (pl.; Persian Sīstān), 259

Solangqas (peo.), 274. Also Koreans

Soltan, the (pr.), 259, 260; see also Jalaldin Soltan, Sultan, the. Also J̌alāl al-Dīn, Muḥammad Šāh of Khwārazm

Soqatai (pr.; a wife of Ambaqai Qa'an), 70+, 71

Soqoq Usun (rv.; tu. 'Cold Water'), 158+, 177. Also Kobdo River

Soqor (pr.; a messenger), 245+

Sorqan Šira (pr.; of the Süldüs; cmdr. of 1000), 82+, 83+, 84+, 85, 86+, 87, 146+, 198, 202, 219+

Sorqaqtani Beki (pr.; wife of Tolui), 186; see also Berüde

Sorqatu Jürki (pr.; son of Ökin Barqaq), 122, 139; in 288 wrongly written Qutuqtu Yürki

Söge'en (peo.), 166

Söndiivu (pl.; Hsüan-te fu), 247

Sönit (cl.), 47

Söyiketü Čerbi (pr.; of the Qongqotan; steward; chamberlain), 120, 124, 191; see also Süyiketü

Sučigil/ Suǰigil (pr.; $2^{\text {nd }}$ wife of Yisügei Ba'atur; mother of Bekter and Belgütei): see Mother Sučigil

Suldus (peo.), 82, 120, 186

Sultan, the (pr.), 257; see also J̌alaldin Soltan, Soltan, the. Also J̌alāl alDīn, Muhammad Šāh of Khwārazm 
Sungari (rv.): see Ula

Suqu Sečen (pr.; of the Barulas), 120+

Sübe'etei (pr.; of the Uriangqat, 1176-1248; younger brother of Jelme; cmdr. of 1000; one of the 'four hounds'), 120, 195, 199+, 209, 221, 257+, 270, 274, 277; also Sübe'etei Ba'adur, 124; Sübe'etei Ba'atur, 120, 236, 262+, 270+; see also Sübegetei

Sübegei Bo’ol (pr.; 'Slave Sübegei’, son of Oqda Bo’ol), 180

Sübegetei (pr.; ; of the Uriangqat), 209; see also Sübe'etei

Sügegei (pr.; an envoy of Činggis Qan), 126, 151, 177; also Sügegei J̌e'ün, 181+; Sükegei, 124, 177; Sükegei J̌e'ün, 120, 151, 177

Sügegen (peo.): see Sükeken

Sükeken (peo.), 120. Also Sügegen

Süyiketü (pr.; of the Qongqotan; cmdr. of 1000), 202; see also Söyiketü Čerbi

Šibir (peo.), 239. Also Ibir Sibir, Sibir (RSH. 2.853)

Šidurqu (pr.; name given to Burqan Qan; see RSH 2.976), 267, 268; see also Burqan, Burqan Qan

Šigi Qutuqu (pr.; foundling; cmdr. of 1000; one of the 'four hounds', and grand judge), 202, 203+, 214, 234, 242+, 252+, 257+; also Šigi Quduqu, 260; Šigiken Qutuqu, 138; Šikiken Quduqu, 135

Šiju'udai (pr.; a son of Način Ba'atar), 46

Šiki'ür (pr.; a steward), 130+, 136

Šilginček (pl.), 282

Šiluqai (pr., cmdr. of 1000), 202

Šin River (rv.; < Sindh), 257+, 264. Also Indus

Šinči Bayan (pr.; one of the two 'Lords of [Mt.] Burqan Qaldun'), 9

Šiqšit (rv.), 239; see also Šisgis

Šira Dektür (pl.; 'Yellow Terrace', = Lung-hu t'ai, some 40 km. NW of Peking), 247, 272

Šira Ke'er (pl.; 'Yellow Steppe'), 67, 252

Širaqan (pr.), 278

Širaqul (pr.; cmdr. of 1000), 202

Širgü'etü (pr.), 149; see also Old Širgōtü

Šisgis (rv.; Šišgid Gol), 144; see also Šiqšit

Ta-ting (fu) (pl.): see Beiging

Tai Temür Taiši (pr.; a younger brother of Ong Qan), 177

Taičar (pr.; younger brother of J̌amuqa), 128+, 129, 201

Taiču (pr.; son of Qutuqtu Yürki), 49, 122, 130, 133, 136+, 137, 179

Taiču Güregen (pr.; brother of Mother Hö'elün). Also Ča'ur Sečen. See RSH 2.765

Taiqal (mt.), 198+

Taki (pr.; of the Suldus), 120; see also Daqai, Taqai

Talasu(t) Steppe (pl.): see Qurban Telesüt 
Talqun Aral (pl.; 'Talqun Island'), 105, 115

Tamača (pr.; son of Batačiqan), 2+

Tamači (pr.; cmdr. of 1000), 202

Tamir River (rv.), 195, 196

Tana Stream (rv.), 107

Tanglu (mt.; < Tangnu), 200

Tangut (peo.): see Tang'ut

Tang'ut (peo.), 152+, 177, 249+, 250, 256+, 267, 268+; also Tangqut,

151; also plural Tang'ud-ud, 265+, 266. See Hsi Hsia kingdom in Subject Index

Taqai (pr.; cmdr. of 1000; envoy to To'oril Qan), 124, 151, 177, 202, 207; also Taqai Ba'atur, 151, 186; see also Daqai, Taki

Tarqut (peo.), 120+, 213

Tarquai Kiriltuq (pr.; a chief of the Tayiči'ut), 72, 79, 81, 141, 149+, 219, 220+; also Tarqutai (pr.), 149+

Tas (peo.), 239

Tatar (peo.), 53, 58, 59+, 67, 68, 132+, 133+, 135, 136, 138, 141, 152,

153+, 154+, 155, 156+, 157, 205, 214+; see also Alči Tatar, Aruqai Tatar, Ayiri'ut Buiru'ut Tatar, Ča'a'an Tatar, Ča'ān Tatar, Duta'ut Tatar

Ta'ur River (rv.), 253+

Tayang Qan (pr.; gür qan of the Naiman), 166, 189+, 190+, 193, 194+,

195+, 196+; also Tayang, 189, 194+; see also Torluq Qan

Tayiči'udai (pr.; in charge of horse herds), 120, 124

Tayiči'ut (peo.; shared ancestry with the Mongols), 47, 57, 72+, 73+, 74,

76, 77, 79+, 80, 81, 82+, 83+, 86, 94, 98, 119+, 138, 141+, 144+,

$146+, 148+, 149,177,196,219+, 257$

Teb Tenggeri (pr.; middle son of Father Mönglik of the Qongqotat), 244, 245+, 246+; see also Kököčü Teb Tenggeri

Telegetü Bayan (pr.; of the 'white' clan of the Jalayir; grandfather of Muqali; see RSH 1.504), 137

Telegetü Pass (pl.), 162, 177; see also Telētü Pass

Telengüt (peo.; plural of Teleng), 207; see also Tenlek

Telētü Pass (pl.), 136; see also Telegetü Pass

Teme'en Steppe (pl.; Teme'en Ke'er), 190

Temüder (pr.; cmdr. of dayguards), 278

Temüge (pr.; youngest brother of Temüjin), 60, 79; also Temüge Otčigin, 60, 99, 245; see also Otčigin

Temüjin (pr.; eldest son of Yisügei and Hö'elün; husband of Börte; father of Joči, Ča'adai, Ögödei, and Tolui; given title Činggis Qan), $59,60+, 61+, 66+, 68+, 69+, 73+, 76+, 77+, 79+, 80,81+, 82,83,84$, $85+, 87,88,90+, 91,92,93+, 94+, 96+, 97+, 99+, 100+, 101,102$, $103+, 104+, 105+, 106+, 107+, 108+, 110+, 111,113,115+, 116+$, $117+, 118+, 121+, 122+, 123+, 126,127+, 146+, 149+, 152+, 160$, 
164+, 166+, 167+, 169+, 170, 174, 177, 195+, 244+; see also Činggis Qa'an

Temüjuin Üge (pr.; a chief of the Tatars), 59+

Temülün (pr.; sister of Temüjin), $60+, \mathbf{7 9}, 99$

Tenggelik Stream (rv.), 100; see also Tünggelik

Tenggeri (pr.; a son of Altan Qan), 253

Tenggis (lk.; 'sea, body of water'), $\mathbf{1}$ (where probably Lake Baikal); also Tenggis Sea (Tenggis dalai: metaphorically and generally, 'the ocean'), 199

Tenlek (peo.), 239; error for Teleng; see also Telengüt

Terge Emel (pr.), 141, 176

Tergüne Heights (mt.), 79

Tersüt (pl.): see Dersüt

Three Merkit, the (pr.) 103+; see also Dayir Usun, Qa'atai Darmala, Toqto'a Beki

Three Rivers, 179; see also Kelüren River, Onan, Tu'ula

Tibetans (peo.): see Töbödüt

Tobsaqa (pr.; cmdr. of 1000), 202

Tobuqa (pr.; cmdr. of 1000)

Tolon (pr.; cmdr. of 1000), 202

Tolui (pr.; youngest son of Činggis Qan), 186, 214+, 242, 243, 251+, 255+, 258, 259+, 269+; see also Prince Tolui

Tolun (pr.; of the Qonqotat; cmdr of 1000; chamberlin), 191, 212, 213,

267+; also Tolun Čerbi, 191, 253, 265, 267+

To'oril (pr.; of the Kereyit), 108+, 134; see also Ong Qan, To'oril Ong Qan

To'oril (pr.; son of Čaqa'an Qo'a), 218+; see also Narin To'oril

To'oril (pr.; of the Söge'en), 166+, 180+, 181

To'oril Ong Qan (pr.; of the Kereyit), 104+; also To'oril Qan (pr.), 105+, 106+, 107+, 108+, 110, 113+, 115+, 126+, 133+, 134; see also Ong Qan, To'oril

Toqočaq Heights (mt.), 12

Toqon Temür (pr.; cmdr. of 1000), 202

Toqto'a (pr.; of the Merkit), 102, 105+, 109, 117+, 144, 157+, 162,

177+, 197, 198+, 199+, 236; see also Three Merkit, the; Toqto'a Beki Toqto'a (pr.; the shaman), $\mathbf{1 8 1}$

Toqto'a Beki (pr.; of the Merkit), 109+, 111+, 141, 142, 157, 177+, 197,

198; see also Toqto'a, Three Merkit, the

Toqu (pr.): see Tuqu

Toqučar (pr.; identification unclear [RSH 2.940, 1031]), 257+, 280

Toqučar (pr.; grandson of Ögödei (RSH 2.1031)

Toqura'ut (cl.), 213; see also Qači'un Toqura'un, Qaraldai Toqura'un, Qaraqai Toqura'un

Torbi Taš (pr.; messenger of Tayang Qan), 190 
Torluq Qan (pr.), 190; also Torluq Tayang (pr.), 189; see also Tayang Qan

Toroqolǰin Bayan (pr.; son of Borjigidai Mergen), 3; also Toroqolǰin, 3

Toruqan (pr.): see Turuqan

Töbödüt (peo.; plural of *töböt before noqot 'Tibetan dogs'), 260

Tödege (pr.), 219; see also Tödöge

Tödö'en (pr.; $7^{\text {th }}$ son of Qabul Qa'an), 51; also Tödö'en Otčigin, 48

Tödö'en (pr.; messenger of Senggüm), 181+

Tödö'en Barula (cl.), 46

Tödö'en Girte (pr.; a chief of the Tayiči'ut), 72+

Tödöge (pr.), 146; see also Tödege

Tö'eles (peo.), 239; see also Tö'ölös

Tögei (pr.; a wife of Toqto'a Beki's son Qudu), 198

Tögüs Beki (pr.; eldest son of Toqto'a Beki), 157

Tö’ölös (peo.), 207; see also Tö'eles

Töregene (pr.): see Döregene

Törölči (pr.; elder brother of Inalči), 239

Tubas (peo.; plural of Tuba), 239. Also Black Forest Tatars

Tumat (peo.), 240+, 241+ ; see also Qori Tumat

Tumbinai Sečen (pr.; son of Bai Šingqor Doqšin), 47, 48; also Tumbinai, 180

Tung-ching (pl.): see Dungčang

Tunggon Pass (pl.; T'ung-kuan), 251

Tungquidai (pr.; cmdr. of 1000), 202

Tuqas (peo.), 239

Tuqu (pr.; $3^{\text {rd }}$ son of Qasar), 183. Also Toqu

Turuqan (pr.), 212. Also Toruqan (RSH 2.797-98)

Tusaqa (pr.), 165

Tu'ula River (rv.), 96, 104, 115, 164, 177+; also Tūla River, 264

Tübegen (cl.), 208; see also Tümen Tübegen

Tüge (pr.; eldest son of Čila'un Qayiči; cmdr. of 1000), 202, 225; see also Tüngge

Tüge Maqa (pr.), 141

Tügü'üdei (pr.; son of J̌adaradai), 40+

Tülkin Če'üt (mt.), 190

Tümelün (pr.; youngest dau. of Činggis Qan; wife of Čigü)

Tümen Kirgisut (peo.), 239; see also Kirgisut

Tümen Oyirat (cl.), 239+

Tümen Tübegen (cl.), 150, 170+, 171+; also Tümen Tübe'en, 187; see also Tübegen

Tüngge (pr.), 137; see also Tüge

Tüngge Stream (rv.), 177+; a problematic reference (see RSH 1.635)

Tünggelik (rv.), 107; also Tünggelik Qoroqan ('Tünggelik Stream'), 5, 28, 30, 32, 35; see also Tenggelik Stream

Tüyideger (pr.; cmdr. of 1000), 202 
U'as Merkit (cl.), 102, 105, 109, 111, 117, 197; see also Merkit Ubčiq (cl.), 160

Udan (pl.), 263. Also Khotan

Udarar (pl.), 257; also Udirar, 258; Udurar, 259+ . Also Otrar

Udutai (pr.; cmdr. of 1000)

Uduyit Merkit (cl.), 102, 105, 106, 111, 114, 199; see also Merkit

Uighur (peo.): see Ui'ur

Ui'ur (peo.; the Uighur), 198 (where wrongly written as ethnicon Ui'urtai); also Ui'ut (plural of Ui'ur), 152+, 177, 238. Also Uighur, Uyiqut

Ui'urtai (pr.), 279

Ula (rv.; ula is 'river' in Jurchen), 253. Also Sungari (RSH 2.921)

Ulǰa (rv.), 132, 133+

Ulqui Šilügely̆it (rv.), 153, 173

Uluq Taq (mt.; tu. 'big mountain'), 144, 158, 177

Uncle J̌̈̈rčedei (pr.), 171; see also J̌ürčedei

Uquna (pr.; envoy of Činggis Qan), 254+

Ural (rv.): see Jayaq

Uraq Čöl Bend of the Kelüren (pl.), 94

Uraqai (pl.), 267+

Urgenč (pl.): see Örünggeči. Also Gurganj

Uriangqai (peo.), 9, 12, 97, 183; see also Adangqan Uriangqai, Uriangqan

Uriangqan (peo.), 120; see also Uriangqai

Uriyang (pl.; erroneous writing for *Yarqand/Yarkend; tu. Yarkänd), 263. Also Yarkand

Ursut (peo.), 239

Urši'un River (rv.), 53

Uru'udai (pr.; a son of Način Ba'atar), 46

Uru'ut (peo.), 46, 130+, 170+, 171+, 175, 176, 195, 208+, 209

Utkiya (pl.), 142

Uyiqut (peo.; plural of *Uyiqur), 151; see also Ui'ur. Also Uighur

Üčügen Barula (pr.; 'Small Barula'), 46

Ülengüt Turas (pl.), 144. Also Hüle'üt Turas (RSH 1.527)

Ünjin (cl.), 122

Ürünggeči (pl.), 258+, 263+; see also Örünggeči. Also Gurganj

Ürünggü River (rv.), 158+, 177

Üsün (pr.), 216; see also Old Üsün

Volga (rv.): see Adil, Eǰil, Idil

Vujiu (pl.; northernmost outpost of the Chin, at Hsing-ho ch'eng [Qara

Balyasun]), 247, 248. Also Fu-chou

Vuqanu (pr.), 253+, 
Wan-yen Fu-hsing (pr.): see Ongging Čingsang [Wan-yen Fu-hsing] Wan-yen Hsiang (pr.): see Ongging Čingsang [Wan-yen Hsiang]

Xalxyn Gol (rv.): see Khalkha River

Yadir (pr.), 170

Yalawači (pr.; administrator, formerly merchant), 263+. Also Maḥmūd Yalavač of Urgenč (RSH 2.962, 3.122)

Yalbaq (pr.; cmdr. of nightguards), 278+

Yarkand (pl.): see Uriyang

Yedi Inal (pr.; chief of the Kirgisut), 239

Yedi Tubluq (pr.; a chief of Buyiruq Qan of the Naiman), 158

Yegei Qongtaqar (pr.; son of Kököčü Kirsa'an), 180+; see also J̌egei Qongdaqor

Yegü (pr.; eldest son of J̌oči Qasar), 183, 269, 280. Also Yekü

Yeke Barula (pr.; 'Big Barula'), 46

Yeke Čeren [son of Qulan Ba'atur] (pr.), 51, 169+; see also Čeren

Yeke Čeren [Tatar chief] (pr.), 154+, 155, 156

Yeke Čiledü (pr.), 54, 111; see also Čiledü

Yeke Ne'ürin (pr.; cmdr. of nightguards), 225

Yeke Nidün (pr.; son of Sali Qača'u), 2+

Yekü (pr.): see Yegü (RSH 2.659)

Yesügei (pr.): see Yisügei

Yesügen (pr.): see Yisügen Qatun

Yesüngge (pr.): see Yisüngge

Yisüder Qorči (pr.; cmdr. of garrison), 274

Yisügei (pr.; ${ }^{\text {rd }}$ son of Bartan Ba'atur; husband of Hö'elün; father of Temüjin), 56, 66, 69; also Yisügei Ba'atur, 50, 54, 56, 59, 60+, 61, 62, 66, 67+, 69, 70, 111, 130, 140, 164; Yisügei the Kiyan, 67; Yisügei Qan, 96, 105, 150+, 177+; Yisügei Qa'an, 150

Yisügen Qatun (pr.), 155+, 156

Yisüi (pr.), 155, 156, 254; also Yisüi Qatun, 155+, 156+, 254, 265+, 268

Yisün Te'e (pr.; son of J̌elme; cmdr. of 1000 quiverbearers), 225+, 230, 234; also Yisün Tö'e, 278,

Yisüngge (pr.; $2^{\text {nd }}$ son of J̌čci Qasar; nephew of Činggis Qan; a noted archer [RSH 3.105-06]), 183, 269

Yuqunan (pr.; tu.-mo. form of Syrian 'Johannes'; envoy of Alaquš Digit Quri), 190+

Yuruqan (pr.; cmdr. of 1000), 202

Yürki (cl.), 49; see also Jürkin 


\section{SUBJECTS}

This index is based on that in RSH 2.1246-314, which should be consulted for additional details on these and many other entries. The following abbreviations are used here: ČQ = Činggis Qan, cmdr. = commander.

abduction: of Börte, 98-103, 101, 102, 104, 105, 111, 254; of Hö'elün, 54-6, 102, 111; of mother of Belgütei, 101, 112; of Ong Qan by Tatars, 152, of Ong Qan by the Merkit, 152; of women, $\mathbf{3 8}$ administration, civil and military: organization of, 124-5, 191-2, 202-34 administration, military: confirmation of ČQ's regulations by Ögödei, 278; formation of right and left wings and units of ten thousand, 104; reorganization of army: by ČQ, 191-2; by Ögödei, 278 adoption: of idu'ut of Ui'ut by ČQ, 238; of ČQ by Ong Qan, 164, 177; (cf. also 167, 181, 183, 200, 204); see also foundlings affection: of Börte for Ča'adai, 254; between ČQ and Ong Qan, 164, 165; ČQ's loss of for Ong Qan and Senggüm, 165, 166; Ong Qan's for Senggüm, 167

agreements: binding quality of, 108; not to be broken, 126; in old days between ČQ and Sača Beki and Taiču, 136; of Senggüm, Ong Qan et al. to seize ČQ, 168 ; see also alliances; promises; word alcoholism: see drunkenness

alliances: between Jamuqa and other tribes, 129, 141; between Chin dynasty and ČQ against Tatars, 133; between J̌amuqa and other Mongols and the Naiman, 194; between the Naiman and the Merkit, 198; between Qan Melik and Jalaldin Soltan against ČQ, 257; see also agreements, marriage; oaths

and $a$ and anda-ship: see sworn friends

anger: of Büri and Güyük at Batu, 275; of ČQ, 240, 244, 246, 260; of spirits of the Kitat lands, 272; of Mother Hö'elün, 244; of Ögödei at Güyük, Harqasun and Büri, 276, 277; fury of Jürkin, 139; fury of Mother Hö'elün, 244

animals, wild (for others, see individual entries), 123, 164, 179, 187 199,

279, 281; asses (onagers), 188, 199, 265, 267; brach, 78; ducks, 200; ermine, 103; field-mice, 89; geese, 27; jackal, 78, lion, 78; marmot, 89, 90, 199; panther, 78; squirrel, 9, 182; stag, 199; tiger, 78; weasel, 103; see also birds; falconry; fish; hawking; hunting; sable; snakes; wolves appointments: of envoys, $\mathbf{1 2 4}$ appointments by ČQ/Ögödei: see RSH 2.1248 archery: practice, 116; skill in, 139, 244 
army, 260; of Boroqul, 240; of ČQ, 183, 195, 247, 248; of Dörbei Doqšin, 240; enlistment to of eldest sons, 270; garrison, 276; great, of ČQ, 146; the Guard and, 226; horses, 199, 195, 224; of Ong Qan, 133, 141, 170; provisioning of, 199; of Tayang Qan, 194; of Yisügei, 150; see also left wing, right wing

arraying troops: $\check{C} Q, 163,177,195$; $\breve{Q} Q$ and Ong Qan, 159; Güčülük Qan and Toqto'a, 198; Kökse'ü Sabraq, 159, 177; of Ong Qan, 170; Yisügei, 177

arrows, 77, 79, 87, 91, 106, 112, 116, 124, 147, 163, 169, 171, 172, 173, 174, 177, 195, 198, 199, 208, 214, 244, 254; arrow-sharpening/ notching knife, 80, 178; arrow-shafts, parable of, 19, 22; for special types of arrowheads see RSH 1.366, 466, 537, 2.713-14, 731-32

assembly: of the colophon, 282; and election of Ögödei as qan, 269 great, and re-election of ČQ as qan, 202; of Mongols and Tayiči'ut to elect Qutula as qan, $\mathbf{5 7}$

autumn: (read spring): of the Year of the Hen (1225), 264; of the Year of the Dog (1202), 153, 177; of the Year of the Dog (1226), 265; of the Year of the Rat (1204), 197

ayil (group of tents belonging to one family), 81, 84, 112

banquet: see feasts

bastard offspring, 254

battue: see hunting

beauty: of Alan Qo'a, 7; of daughters/granddaughters of Onggirat, 64-5,

176; of Hö'elün, 54; of lady, 75; of Tumat girls, 241; of women and girls, 121, 123, 179, 197

betrothal: of ČQ and Börte, 66; of daughter of Ambaqai Qa'an, 53; feast,

168, 204; future son-in-law left with future father-in-law, 66, 155; of J̌irgin girl servants, 185 ; see also wife-to-be

beverages: see drink

billygoats: gelded, $\mathbf{2 6 4}$

birds: buzzard, 111, 200; crane, 111; crow, 111, 124, 200, 210; duck, 27, 31, (mandarin) 78, 200; falcon, 195, 249, 260, 266; flock of, 245, 254; geese, 27, 31, 111; gerfalcon, 63, 78, 199, 239; grouse, 25; hawks, 25 9, 31; lark, 77, 160; skylark, 160; sparrow, 85; sparrow-hawk, 85; swan, 111; see also falconry; hawking

birth: afterbirth, 78, 244; birth cord, 244; of ČQ, 59, 97, 211; Heaven and, 21; heavenly yellow man and birth of Alan Qo'a's sons, 21; high/ higher, 201; images of, 78, 244, 254; magic and, 174, 189; outside marriage, 17

birthplace: of ČQ, 59, 97, 211

bit (of horse's bridle), 199

blizzard, 108

blood, 194; black, 254; clogging wound, 145, 173, 214; clot, 59, 78; and birth of ČQ, 59; clotting, 145, 173, 214; ČQ and J̌amuqa of kindred, 
105; drinking camel's, 151, 152, 177; execution without shedding, 201; shedding, 178; spitting, 145; sucking from wound, 145, 173, 214 body: big of Barulatai, 46; cleaning, 254; of ČQ, 245; in pain, 265, 267; disappearance of Kököčü Teb Tenggeri's, 246; Ong Qan and Senggüm, 188; Qasar and companions, 183; Sača Beki and Taiču, 136; Širgü'etü and his sons, 149; Toqto'a and Dayir Usun, 109; Toqto'a Beki and his sons, 197, 198; examination of, 197; must have head, 33 body parts: afterbirth, 78, 244; back/backbone, 194, 245; birth cord, 244; bosom/breasts, 244, 245; 275, 276; buttocks, 277; cheeks, 123, 171, 174, 179, 194, 197, 208; ears, 254; ears to hear, and eyes to see 138, 203, 252; eyes, 62, 66, 77, 82, 114, 145, 149, 194, 254: single, in forehead, 4; face, 62, 66, 82, 149, 152, 201: spitting in, 152; feet, 254 275, 279, 281; finger, 178; fists, 227, 278; hands, 279, 281: washing of, 189; head(s): 33, 111, 123, 254: destroyed, 189, 198, 229, 255, 278, 280; heart, 69, 75, 84, 104, 105, 125, 173, 178, 181, 194, 199, 200, 201, 205, 219, 230, 240, 254, 260, 265, 267, 277; heels, 254, 255, 275; kidneys, 96, 104; lungs, 13, 139; nails (of finger), 276; neck, wounded, 145, 173, 214, 254; nose, 280; ribs, 12, 127; rump, of horse, 184; sinews, 183; skin: black, 195, 200, 201; stomach, 137, 145, 195, 214; kicking pit of, 137; teeth/fangs, of snake: 164, 177; tendons, 137; thigh, 163, 177; throat, 149: and choking, 213; tripe, 124; vein, in neck, 145, 173; womb, 21, 22, 78, 121, 244, 254; see also liver; spine

book: see writing

booty: see plundering

bowls and vessels: golden, of Ong Qan, 187; golden and silver, 267;

nightguards and, 232, 278; stewards and, 229

bows, 87, 91, 190, 195, 234, 279; bowstring, 106, 116

bride: accompaniment of by father, $\mathbf{5 3}$; family of, $\mathbf{6 5}$

bridegroom: custom of leaving with family of bride, 66; family of, $\mathbf{6 5}$; of Yisüi Qatun, 155, 156

bridles, 199, 229, 278; see also bit

brothers (= cousins): of J̌amuqa, $\mathbf{1 6 0}$; see also younger brother

Buddhism: see RSH 1.xxv, 282; 2.785

Buddhist images: $\mathbf{2 6 7}$

bull: black, 106; hide of covering a drum, 106; red, 240

burial: decapitation when not possible, 198; in elevated places, 201; execution without, 188 (of Kököčü), 136 (of Sača Beki and Taiču); of J̌amuqa, 201; killing of Büri Bökö/Itürgen without, 140, 184; with quiver and bow, 190; of Quyildar, 175

butchering: ox, 214

calf: horns of, 116; wheel-tied, 194

camels, 64, 78, 152, 182, 249, 250, 264, 265, 266, 267; Bactrian, 274;

black, 64; drinking blood of, 151, 152, 177; foal, 78; pulling carts, 64; 
white, 244; see also dromedaries

campaigns, 233, 254; in Khorasan by Tolui, 259; in Korea, 274; raid in north Caucasia by Sübe'etei (and Jebe), 262; Western (against Muhammad Šāh of Khwārazm), 254-64; see also battles in RSH 2.1250-51

campaigns against: Baqtat and the Qalibai Soltan by Čormaqan, 260, 270, 274; Buyiruq Qan and the Naiman by ČQ and Ong Qan, 158, 159, 177; cities Aru, Maru and Abtu by Dörbei, 261; cities Meket, Menkermen Keyibe and others by Sübe'etei, 270; ČQ and Ong Qan by J̌amuqa and allies, 141-4; ČQ by J̌amuqa, 129, 201; Güčülük of the Naiman by J̌ebe, 202, 237 Jurchen/Chin [Kitat], 247-8, 249, 250, 251, 252; Jurchen/Chin [Kitat and Jürčet] by Qasar, 253; Jurchen/Chin [Kitat] by Ögödei, 271, 272; Jamuqa and his allies, 141-4; the Jaqut by Ögödei, 281; the Jürčet and the Solangqas by J̌alayirtai Qorči, 274; Jürkin, 132, 136; Kereyit, 185; the Kibčaq, 275; the Merkit by ČQ, Ong Qan and Jamuqa to rescue Börte, 104-13; the Merkit by ČQ in 1204, 197; the Merkit by Sübe'etei, 199, 236; northern India and Kashmir by Oqotur, 274; Ong Qan and the Kereyit, 185; the People of the Forest by J̌oči, 239; the Qanglin, Kibča'ut and Bajigit by Batu, Büri, Güyük, Möngke and other princes, 274; Qarlu'ut by Qubilai, 235; sons of Toqto'a Beki by Sübe'etei, 199, 236; Tangut Hsi Hsia, 249, 250, 265-8; Tatars, 157; Tatars by ČQ, Ong Qan and Ongging Čingsang, 132-3; Tatars by ČQ and Ong Qan, 136; Tatars by Jurchen/Chin, 132-3; Tatars by Qutula and Qada'an Taiši, 58-9; Tatars by Yisügei, 59; Tatars in Year of the Dog (1202), 153; Tayang Qan and the Naiman, 189-96; Toqto'a Beki and the Merkit, 177, 197; Toqto'a Beki and the Merkit by Ong Qan, 157; the Tumat by Boroqul, 240; the Tumat by Dörbei, 240

camps: see RSH 2.1255-56; and for circular camps, RSH 2.1259

cangue, 81, 84, 85, 112, 146

capture (of places): of Beiging by Qasar, 253; of cities of Iru, Isebür etc. by Tolui, 259; of Čabčiyal Pass by J̌ebe, 247, 248; of Dungging by J̌ebe, 247, 248; of Gurganj, 260; of Otrar, 259 of Örünggeči by J̌oči,

Ča'adai and Ögödei, 260; see also campaigns against 'caragana' marching-order, 195 carriages, 64

carts, 55, 56, 85, 86, 100, 118, 145, 149, 232, 233, 280; axle-carts, 124; axletree of, 101; black covered, 6, 244; felt-covered, 6, 244; closed, 101; iron, 199, 236; large, 64; linchpin of, 154, 156, 214; line of, 245; lock-carts, 115, 124; pulled by camels/bulls, 64, 195; and sheep, 124; two-wheeled, 177; see also shafts; tent-carts

celebrations: at election of Qutula as qan, 57; see also dancing; feasts children, 72, 74; adopted, 119, 135; of ČQ, 242; as gift, 97, 114, 119, 135, 137; given into service, 15-16; of Hö'elün, 135; role of father in deciding fate of, 15-16; see also orphaned children 
Chin dynasty: alliance of ČQ with against Tatars, 133; see also Jurchens, Jürčet in the Name Index

Christianity: see Nestorian Christianity/Christians in RSH 2.1285

cities, 247, 270; resident commissioners in, 263; scouts and garrison troops in, 281; Kitat, 272, 273; laws and customs of, 263; of Qan Melik, 257; of the Sarta'ul, 260; three, 151; see also towns; and see details in RSH 2.1304-5 (subjugation; submission)

civil administration: establishment of by $\breve{C Q, \mathbf{1 2 4 - 5}}$

clans: defecting from Jamuqa to ČQ, 120-2; questions as to which a person belongs to, 15, 20, 38, 156; see also genealogy; kinship; and individual clans, '(cl.)', in the Name Index

cliffs, 26, 78, 79, 164, 179

cloth: brocades, 238, 274; damasks, 238, 274; naq-fabrics, 274; satin, 234, 238, 248, 249, 250, 252, 260, 265, 279; silk, 238, 248; ; weaving, 249; woollen, 184, 265; see also felt; sable

clothing, 145; blood-stained, from enemy, 195; confiscation of, 229, 278; gold-embroidered, 188; of Mongols, 189; robbery of, 136

clothing, items of: cap, sable, 114; cloak, 95, 205; dress, 114, 216; pants, 145; robe, 254; shirt, 55; skirts, 74, 174, 254, 266; swaddling clothes,

97, 211; waistcoat, 135; see also coats; hat clouds, 238

coats: collar of, 33; crimson, 238; kidskin, 152; lapel of, 201; red, 146; sable, 96; sheepskin, 112; see also Red Coats cold, 207, 213, 230

colts, 149

cmdrs. of a hundred, 191, 224, 225, 270, 280; outside cmdrs., 228, 278

cmdrs. of a thousand:191, 202, 203, 209, 212, 213, 221, 222, 223, 224, 269, 270, 278, 280; of dayguards, 226; of Kirgisüt, 239; list of ninetyfive (eighty-eight), 202; of nightguards, 225; of quiverbearers, 225; outside cmdrs., 228

cmdrs. of companies, 229, 278; of dayguards, 227, 278; of nightguards, 278; of quiverbearers, 225, 278

cmdrs. of dayguards, 191, 226

cmdrs. of nightguards, 225

cmdrs. of ten, 191, 224, 225, 270, 280; of Kirgisüt, 239; outside cmdrs., 228,278

cmdrs. of ten thousand, 121, 205, 206, 207, 210, 220, 224, 269, 270, 280 cmdrs., 253, 277; and princes, 265; of peoples given to ČQ's family, 243 companions: Bo'orču, of ČQ, 90, 92, 93, 95, 205; of ČQ, 201; Boroqul and the other foundlings, 214; Jaqa Gambu, 150; J̌ebe, 147; J̌elme, 211; luck/good fortune of, 125; Mulqalqu, 223; senior ones who left J̌amuqa, 125; ČQ, of Ong Qan and J̌amuqa, 113; ČQ and J̌amuqa, 200, 201; Father Mönglik and ČQ, 245; of Jamuqa, 200, 201; J̌amuqa on Ong Qan as, 170; of Ong Qan, 179; of Ögödei, 277; of Qasar, 183; of recruits to guards, 224; of Tenggeri, 253 
concubines, 43, 121; Merkit women made, 112

containers: bags (leather) for kumis, 132; buckets/pails: covered, 145; leather, 87, 90, 93, 205, 254; casket, birch-bark, 178; cauldrons, 129, 277; piss-pot, 203; pitchers, for kumis, 130, 213, 232, 245, 278; vessels, 187, 232, 267, 278; see also bowls

cooking: see food

cousins: see brothers

cowherds, 232, 234

cows: fallow, 121; milking of, 189

crimes: exemption from punishment for up to nine, 203, 205, 211, 214,

219; see also law, punishment; and RSH 3.112-13

customs, 71; and laws of cities, 263; sharing of prey, 13; see also drinking; great norm; law; proverbial sayings

dancing: around the Leafy Tree at election of Qutula as qan, 57, 206 daughters-in-law: of Gürbesü, 189; of Mongols to be servants of Naiman, 189; of Ong Qan, 177; rites pertaining to, 189

dayguards, 245; duties of, 192, 229, 234, 278; great, 230; handed over to Ögödei, 269; Kitat, 253; organization of, 191, 224, 225, 226, 227; recruitment to, 191; reserve, 278; and security of Palace, 234; service, 278; seventy, 191, 192, 224; see also roster

death, 245, 254; depth of water and, 277; life and, 195; meeting, 208; without shedding blood, 137, 201, 245

death of: Boroqul, 240; Ča'adai, 1242 (RSH 2.864); Iluqu Burqan, 267+, 268; J̌amuqa, 201; Kököčü Teb Tenggeri, 245, 246; Ong Qan, 188, 189; Ögödei, 1241 (RSH 1.624); Quyildar, 175; Tayang Qan, 196; Tolui, 272; Temüjin/ČQ, 268; Yisügei, 67-8

death-companion, 149

decrees: on apportionment of subject peoples to ČQ's kin, 242; on booty after battle at Dalan Nemürges, 153; of Eternal Heaven on ruler, 244; that field matters be decided in field, domestic matters in tent, 277; that Ögödei be ČQ's successor, 269; see also law; orders of ČQ deer, 12, 13, 14, 16, 103

destiny, 195; of blue-grey wolf, 1 ; decreed/ordained by Heaven and Earth, 194, 248, 281; ordained by Heaven, 201

destruction: of the Altan Qan [Hsüan-tsung], 251; of ancestors of the Mongols, 266; of cities and towns of the Kitat, 272; of cities of Sisten and Čučeren by Tolui, 259; of city of Dörmegei, 267; of city of Meget, 274, 275; of Ča'ān Tatar, Alči Tatar, Duta'ut Tatar and Aruqai Tatar, 153; of enemy people, 244; of the Jaqut, 281; of the Jürkin, 139; of Jüuin and Jürčet troops, 248; of the Kereyit, 187; of Kitat troops, 251; of land and waters of the Kitat, 272; of the Merkit, 104, 113, 200, 236; of the Naiman, 200, 237; of people of Toqto'a Beki, 105; of the Tang'ut, 266, 268; of the Tatars, 154; of the Tayiči'ut, 148; of troops of Jalaldin Soltan and Qan Melik, 257 
dew, 195

disloyalty, treachery: of J̌amuqa, 201; of J̌amuqa's companions, 200; similes for, $\mathbf{1 6 4}$

disobedience: admonition against, 203; of Altan, Qučar and Dāritai, 153 doe: boots made from forelegs of, $\mathbf{1 1 4}$

dogs, 255; barking of as bad omen, 189; ČQ afraid of as a child, 66; fight of, 194; Qasar, 78; used figuratively, 260; woman with face of, 188; yellow, 21

domestic matters: to be decided in tent, field matters in field, 277

door, 165, 167, 245, 246; of closed cart, 101; closed to Burqan Qan, 267; felt, 77, 137; frame, 105, 109; left-hand, 112; near inside of, 214; opened by Heaven, 208; of Palace, 229, 232, 278; place beside, 165; place facing, 165; right-hand, 112; sacred frame of, 105, 109; slaves of, 137, 180, 211; top of, 21; wooden, 203; see also threshold

dowry, $\mathbf{4 3}$; servants as, $\mathbf{4 3}, \mathbf{2 0 8}$

dragon-snake, 78, 195; see RSH 2.715-18

drink: for feasts, 279; libation, 103; nightguards and, 232, 278; preparation of, 85; sacrificial, 70; thirst, 145, 254

drink, types of: ewes' milk, 87, 93; kumis, 28, 31, 85, 130, 132, 145, 213, 232, 245, 278; soup/broth, 192, 214, 229, 279, 280; see also milk, wine

drinking: in company, 156; customs, 130; drunkenness (of Ögödei, Tolui), 281, 272; stewards and, 124, 130; see also wine

dromedaries: Arabian, 274; see also camels drunkenness: of Ögödei, 281; of Tolui, 272

dwellings: in circle, 90; grass huts, 24, 28; with walls of pounded earth, 203; with wooden doors, 203; see also ayil; palace; tents

earth: brown, 245; crusty, 254; pounded walls made from, 203, 249, 265, 281; resting feet and hands on, 279, 281

elk, 103, 255

enemies: admission of hostile actions by, 147; Jürkin, 136; Kitat, 247; mortal, 133, 149, 199, 210; Ong Qan and his allies, 170, 173; peoples, 244, 260, 270; poisonous words of, 267

entrails: of deer, $\mathbf{1 2}$ divination by inspection of, $\mathbf{2 7 2}$ envoys: from Alaquš Digit Quri to CQQ, 190; appointment of, 124; from ČQ to Burqan Qan, 256, 265; from ČQ to J̌au Gon, 251 from ČQ to the Sarta'ul, 254; from Gücülük Qan to Tayang Qan, 194; from idu'ut of the Ui'ut to CQ, 238; interference with by the Altan Qan, 251; to J̌amuqa, 127; to Naiman, 160; from Ong Qan, 184; to Ong Qan, 126, 133, 151, 177; from Ong Qan to ČQ, 163; from Tayang Qan to Alaquš Digit Quri, 190; killing of Uquna and other envoys, 254 epithets: see RSH 1.236, 2.1267 for many terms like ba'atur 'valliant...', bayan '...the rich', ï̈in... 'lady', etc. used with proper names 
Eternal Heaven, 172, 187, 199, 208, 224, 240, 244, 256, 265+, 267, 275; see also Heaven

etügen ötögen: see Heaven and Earth, Mother Earth

ewes: milk of, $\mathbf{8 7 ,} 93$

execution: of Sača Beki and Taiču, 136; for breach of law by Toqučar, 257; for breach of law on care of army mounts, 199; of Burqan Qan, 268; of Čaqa'an U'a, 129; of Činōs princes, 129; of Doqolqu Čerbi, 281; and duties of judge, 203; of guards for breaches of the law, 227, 278; of Jamuqa, 201; of J̌aqa Gambu, 208; by kicking in pit of stomach, 137; of Kököčü, 188; for laying hands on lord/qan, 149, 200; of male Tatars, 154, 156; of Megüjun Se'ültü, 133, 134; of Merkit rebels, 198; of People of the Forest for acting without Qorči's agreement, 207; reason for, 201; of Sača Beki and Taiču, 136, 137 of Toqto'a's sons ordered by ČQ, 199; for unauthorized entry into Palace, 229, 278; without shedding blood, 137, 201; of Yisüi Qatun's husband, 156; see also linchpin

exile: for evasion of recuitment to guards, 224; of Güyük and Harqasun,

276; for failure of member of Guard to take turns of duty, 227, 278 eyesight: long-range, of Du'a Soqor, 4

falconry, 54, 189, 249; nightguards and, 232, 233, 278; see also hawking fallow doe: wife of blue-grey wolf, $\mathbf{1}$

families: groups of related, $\mathbf{1 5 6}$

family fire: youngest son as custodian of, see otčigin

family: of Alči, 226; of Boroqul, 241; of Bo'orču, 226; of the bride, 65; of the bridegroom, 65; CQQ and J̆amuqa of the one, 105; of Ilügei, 226; of Jürčedei, 226; of Muqali, 226; of Ögödei: boastful talk against, 276; and offering of a substitute from, 272; rejection of members of, 23-4; Dobun Mergen by the sons of Du'a Soqor, 11; Hö'elün and children, 70-5; J̌e'üredei, 44; seniority in, 46

father: and accompaniment of daughter to bridegroom's house, 53; of Altan, 179; of Bo'orču, 90, 92, 95, 205; of Ča'adai, 254; of Čimbai and Čila'un, 85, 146; ČQ, 269, 272; of ČQ, 73, 96, 104, 105, 163, 164, 177, 242; of Ibaqa Beki, 208; of Masqut, 263; of Muqali, 206; of Narin To'oril, 218; of Ong Qan, 150, 152, 167, 177; of Ögödei, 255, 270, 271, 277, 278, 279, 281; of Qulan Qatun, 197; of Qutu and Čila'un, 162, 177; role of in deciding fate of children, 15-16; of Senggüm, 167; Tarqutai Kiriltuq, 149; of Tayang Qan, 194; of Tolun Čerbi, 212; see also adoption; and see Father Mönglik in the Name Index

favour shown: to Arqai Qasar by ČQ, 191; to Arslan Qan by $\check{C} Q, 235$; to Bo'orču and Muqali by ČQ, 266; to Father Mönglik by ČQ, 204; to idu'ut of Ui'ut by ČQ, 238; to Jaqa Gambu by ČQ, 186; to Jebe and Sübe'etei by ČQ, 257; to J̌oči by C̆Q, 239; to Jürčedei by ČQ, 208; to Naya'a by ČQ, 149, 197; to Ong Qan by C̆Q and his father, 164, 177; 
to Qadaq Ba'atur by ČQ, 185; to Qongqai Qorči, Qongtaqar Qorči and Črmaqan Qorči by ČQ, 260; to Qorči by ČQ, 207; to Qubilai by ČQ, 209; to Quduqa Beki by ČQ, 239; to Qulan Qatun by ČQ, 197; to Quyildar's descendants by ČQ, 185; to Šigi Qutuqu by ČQ, 203, 252; to Tolui and Čügü Gürigen by ČQ, 251; to wife of Kököčü (Senggüm's equerry) by ČQ, 188

favourable time: decreed by Heaven and Earth, 194, 248

feasts, 50, 67, 81, 240; betrothal, 168, 204; at election of Qutula as qan, 57; in the forest by the Onan, 50, 130-1, 136; levies to provide for, 279; of Ong Qan, 184, 185; parting, 275; at renewal of friendship between ČQ and J̌amuqa, 117

felt: cart covered with, 6, 244; cloak, 205; covering, 124; door, 77, 137; rug, white, 189; walls of tents, 202, 203, 230; wind-break, 124

female offspring: rewarded, 215

fences, 281

feud: between ČQ and Jamuqa, 127, 200, 201; between ČQ and the Jürkin, 131-2; between Tatars and ČQ's family, 67-8, 132-4; see also revenge

field matters: decree that they be decided in field, $\mathbf{2 7 7}$

fires: lit as ruse, 193; see also hearth

fish, 75, 199; dace, 76; fingerlings, 75 ; grayling, 75; pike, 78; salmon,

75; sturgeon, 272; trout, 272

fishermen, 109

fishing, 75, 76; equipment, 75, 199

flocks: of birds, 245, 254; of sheep, 195, 279, 280

foals, 195; foaling, 117

fog, 213

food: child exchanged for, 15-16; distribution of, 213, 232; gathering of, 74-5; leftovers, 234; nightguards and, 232, 278; not to be digested, 201; as offering, 272; porridge, 46; preparation of, 12, 19, 85, 87, 169, 200, 232; rules and customs regarding, 71; sacrificial, 70, 71; seniority in preparation of, 46; sharing of, 13, 70-1; washing hands, 189; see also containers; drink; feasts; hunting; meals

food, types of: butter (of affection), 254; curds, 145; egg (rotten), 276; fat, 255; hides (eating of), 183; human flesh, 195, 251; sinews, 183; see also fish; meat; milk; plants

fortifications: see palisade/stockade

foundlings, 138, 214; Boroqul, 137, 138, 214; Güčü, 114, 138, 214;

Kököčü, 119, 138, 214; Šigi Qutuqu, 135, 138, 203, 214

'four hounds', 195, 209

'four steeds', 163, 177, 209; and rescue of Ong Qan's people, 163, 177; and rescue of Senggüm's wife and people, 163, 177

fratricide: murder of Bekter, 77, 78

freeman: Badai and Kišiliq, 51, 187, 219; master of, 51; Sorqan Šira made, 219; see also service 
friends: grown tired of, 118, 179; lack of, 76, 77

friendship: Bo'orču on, 92; ČQ and Bo'orču, 92, 93, 95, 125; ČQ and J̌elme, 125; oath of, 141; of Ögödei, Boroqul and Bo'orču, 172; see also alliances, companions; sworn friends

fruit: bird cherries, 74; crab apples, 74

game: see animals; hunting

games: see knucklebones; archery; wrestling

garrisons: army, 276, 274; establishment of, 273, 281; troops, 274

geldings, 170, 172, 177, 229, 234, 239, 248, 254, 267, 272, 278; to be used as post horses, 280; care of, 199; of dayguards, 192; fat, 190, 194; fattening of, 181, 193; fine, 3 ; with fine croups, 123, 179, 197; gold-saddled black, 184; lean, 190, 193, 194; light-bay, 77, 90, 205; men in charge of, 124, 131; rump of, 194; seventy-three, 201; two, 169; white, 216, 239

genealogy/lineage: of ČQ, 1-60; of J̌amuqa, 40; of Tayiči’ut, 148; see also kinship; offspring of offspring; relatives

gifts: birth, 97, 211; boys and girls as, 267; from Burqan Qan to ČQ, 267; child as, 97, 114, 119, 135, 137; daughter as, 197; exchange of by sworn friends, 116, 117; from idu'ut of the Ui'ut, 238; to J̌či and ČQ, 239; reciprocation of, 96; of Tang'ut people to Yisüi Qatun, 268; wedding, 96; see also tribute

girls: fate of, 64-5, 66; as gift to ČQ, 267; taken by Ögödei from

Temüge, 281; 30 requested by Qorči, 121, 207, 241; of Tumat, 241

goats: milking, 151, 152, 177; billy-goats, gelded, 264; see also kids good fortune: of Heaven, 74; of Ögödei, 275; of sworn friend of ČQ,

200; see also supernatural

gorges, 111

government: of ČQ's people after his death, 245, 254, 272; by ČQ's successor, 255; of Ögodei, 270, 278, 279, 280, 281 of Ong Qan's people, 164; of the people by the qan, 179; of Tumat by woman, Botoqui Tarqun, 240; see also great norm

grain: land-tax, 279; pounding of, 152; grainkeepers, 279, 280; grain-

stores, plundered, 177; see also storehouses

grass: fresh, 255; for horses, 177

grazing grounds, 219, 255, 279, 281; see also pasture

great norm/principle (yeke yosu/töre [ törö]): principle of mutual obligations between lord and subject, 178, 197, 208, 220, 252, 281; see RSH 2.791

Guard, the: command of, 278; Č's successors and, 231; disciplining of, 227, 278; duties of, 226; organization of, 191, 224, 226, 227; recruitment to, 224, 225; standing of, 228, 278; turn of duty of, 227

guards: of ČQ handed over to Ögödei, 269, 270; at door of ČQ's tent, 192; duties of confirmed by Ögödei, 278; of golden threshold, 137; on internal duty, 270; of land-tax grain storehouses, 279; see also roster 
halter, 56; golden, 254, 256; halter strap, 103

harness/harnessing, 64, 99, 100, 121, 244, 245, 280

hat, 145, 244; losing, 245; removal of, 103, 244; tall, 74, 254; 'teachings of the hat', 255

hawking, 27, 28, 31; see also falconry

hearth: ashes, 87, 112, 146, 148, 265; destruction of Bekter's, 77; fire of, 242; fireplace, 245. See also otčigin

Heaven, 21, 44, 74, 80+, 143, 145, 167+, 179, 197, 201, 207, 246, 268+; ascension of ČQ to, 268; and bearing children, 21; Buyiruq Qan and Quduqa not loved by, 143; decree of, 244; and destiny ordained by, 1, 201; door opened and reins loosened for ČQ, 208; good fortune of, $\mathbf{7 4}$ intervention of in career of ČQ, 80; judgement of, 265; and $\breve{\text { higeli }}$ sacrifice, 43 ; love of, 143, 167, 246; offering to, 44; prayer to before campaign, 240; prophecy fulfilled by, 207; protection of, 145, 179, 187, 199, 203, 256, 265; and the sons of Alan Qo'a, 21; strength and power from, 199, 224; strength increased by, 267; strength of, 275; subjugation sanctioned by, 265; warning from, 80; will of, 197; see also destiny; Eternal Heaven; Heaven Above; Mighty Heaven. And cf. RSH 1.224-27

Heaven Above, 1, 177, 199

Heaven and Earth, 113, 121, 125, 163, 194, 208, 224, 248, 260+; destiny decreed/(pre)ordained by, 194, 248, 281; favourable time decreed by, 194, 248; protection of, 125, 163, 177; strength/power increased by, $113,125,208,224,260$

heavenly signs, 121, 206, 244; see also supernatural

herds, 168, 190; of horses, 124, 153, 201, 205; plundered, 177

hills, 55, 56, 77, 90

horns: cow, 121; excrescence on forehead of horse, 117; ox, 121, 214

horse-herders, 118, 234; Badai, 169, 219; Čigidei, 170; Kišiliq, 169, 219;

Qutu, 124; of milch mares, 279, 280; Yadir, 170

horses, 174, 184; of army, 199, 224; Bo'orču's shot, 172; carrying goods, 248; ČQ's fall from, 265; dung of, 174; equipment for, 91 (see also specific entries); fattening of, 168; hair of, used for snare, 25; Itürgen's shot in rump, 184; Josotu Boro, 265; mare's milk, 85, 90; Merkit, 169; nine, 77, 99; as pledge, 66; post, 280; reserve, 195; Senggüm's shot in thigh, 163, 177; shooting of ČQ's, 147; spare, 247; of various colours and descriptions, 24+, 25+, 90+, 91, 95, 106+, 117, 147, 152, 169, 177, 193, 205+, 255, 273; tether, 110, 131; Western (Arab), 274; whip, 76, 77, 78, 125, 195, 255; white Merkit, 169; wild, 199; see also colts; geldings; herds; mares; pack-horses; stallions

Hsi Hsia kingdom: campaigns against, 249, 250, 265-8; marriage alliances with ČQ, 249; settled way of life of, 249, 265; submission of, 249, 250

hunting, 9, 26, 109, 115, 123, 164, 175, 179, 187, 219, 255, 265; battue, 
123, 179, 187, 219; 199; grounds, fencing in of, 281; nightguards and, 232, 233, 278; see also animals; birds; fish; implements; sable

implements: adze, 240; awl, 195; axe, 214, 240; bellows (smith's), 97, 211; cangue, 81, 84, 85, 112, 146; chains, iron, 195; chisel, 195, 240; cup, 179, 188; knives, 149, 214, 154: for arrows, 80, 178; ladle, 277; lasso, 199; mortar, 152; needle, 75, 195; pole-lasso, 91; saw, 240; seine, 75; snare, 25; steel (to strike fire), 87; stick, pointed, of spruce, 74; string: piece of, 280; thread, 137; whips, 76, 77, 78, 125, 195, 255; see also arrows; bows; bridles; containers; halter; harness; nets; quivers; saddles; spears; swords; weapons; wheels

jealousy, 164: of chamberlains for nightguards, 233; J̌amuqa's of ČQ, 179; Senggüm's of ČQ, 181; Tayiči'ut kinsmen's of ČQ, 94, 82, 219 judge(s): Belgütei as, 154; Šigi Qutuqu as, 203, 234

judging: by Eternal Heaven, 265; of falsehood, 154, 203; of litigations, 154; of theft, 154, 203

judicial system: see judge(s); judging; law; punishment Jurchen/Chin dynasty: see Chin dynasty

jam: see post-relay system

jasaq: see law; see also the entry in RSH's Index of Grammar \&Lexis, 2.1325; and RSH 3.95-97, 112-13

kids: hoof of, 277; muzzling, 151, 152, 177; skin of , 152, 195

kinship system: see clans; epithets; genealogy; also RSH 1.249-50

kinship terms: see kinship system; offspring of offspring; relatives. And see RSH entries such as 'sons: of...' [2.1302-3], 'mother: of...' [2.1284], 'great-great-grandfather: of ČQ' [2.1273]; also entries for specific Mongol terms in RSH's Index of Grammar \&Lexis

Kiyat Borjigin lineage: and split with the Tayiči'ut, 70-5

knucklebones, 59; copper, 116; roebuck, 116

'lake' battle-formation, 195

lamb, 87, 93, 169; dried meat of, 19; herders of, 118

land and waters of the Kitat, spirits of, 272

land tax: grain, 279

lasso, 199; pole-lasso, 91

law: breach of and compliance with, 252; breach of by Toqučar, 257; breaches of by guards, 227, 278; on care of army mounts, 199; and customs of cities, 263; on immediate conveyance of qan's property to qan, 197; and lighting camp fires on Sa'ari Steppe, 193; on limited/ controlled hunting, 199; records: of decision in judicial matters, 203; see also great norm

left wing, 104, 198, 253; error for right, 198; ten thousand of, thousand of (see under units) 
levies: of camels by Burqan Qan, 249; of mare's milk for feasts, 279; of sheep to support poor and needy, 279, 280; of sheep to support qan, 279, 280; to supplement troops and mounts, 224; to support poststation system, 280; see also taxation

levirate: and Čaraqai Lingqu, 47; in relation to Alan Qo'a, 18

lice, 103, 201

linchpin of cart, 124; measurement against (to avoid executing children), $154,156,214$

liver: cut out, 137; gall in, 139; pain in, 105; rotten, 152; term for close relatives, $\mathbf{1 0 5}, \mathbf{2 7 5}$ n.; torn to pieces, $\mathbf{1 1 3}$

livestock: acquisition of by robbery, 39; Ong Qan's captured, 162, 177; sharing of, 23; Tatar, 132

loot: see plundering

love: and Börte, 254; of ČQ for Qulan Qatun, 197; Heaven's, 143, 167, 246; of sworn friends ČQ and Jamuqa, 116, 117, 118; Yisügen Qatun and, 155; see also affection, friendship

loyalty: of Naya'a to ČQ, 197; oaths of to ČQ, 123, 178; of Önggür to ČQ, 213; of Qorči to ČQ, 207; to rightful lord, $\mathbf{1 8 5}$

magic: see rain; sacrifices; supernatural

main body of the army $(q o l), \mathbf{1 7 0}, \mathbf{1 9 5}, 247$

manoeuvres/tactics: arraying troops, 159, 163, 177, 195, 198, 170; 'chisel' combat 195; decoy manoeuvre, 240; encirclement, 195; fighting a dog's fight, 194; 'lake' battle-formation, 195; random shooting of arrows, 198; regrouping troops, 173; retreat, 195; storming, 247; Tayang Qan's at Mt. Qangqarqan, 194; turning about, wheeling, 170; withdrawal, 248, 253

mares: foaling, 117; let loose, 145; levy of, 280; milch mares, 279, 280; milkers, 279; milking, 90, 145, 205, 279; sacrifice of, 141; of various colours and descriptions, 55, 87, 90, 117, 205

marriage: of Barqujin Qo'a to Qorilartai Mergen, 8; and custom of father accompanying bride to bridegroom's home, 53, 94; and custom of leaving bridegroom with family of bride, $\mathbf{6 6}, \mathbf{1 5 5}$; of ČQ and Börte, 94; of ČQ and Yisügen and Yisüi, 155; of ČQ to Gürbesü, 196; of ČQ to Ibaka Beki, 186, 208; of Dobun Mergen and Alan Qo'a, 9; of Huǰa'ur Ǚin and Toqto'a, 177; and political power, 64; principle wife, 155; wedding gifts for father/mother of bride, 96; see also betrothal; concubines; dowry; levirate

marriage alliances: with Oyirat, 239; with the Önggüt, 239; with People of the Forest, 239; proposal of with Ong Qan, 165, 168; with Qarluq Turks, 235; with Tangut Hsi Hsia, 249; with the Uighurs, 238 meals: of ČQ, 268; noon, 170; sacrificial, 70; supper, 254

meat: black, 167; of deer, 13, 15; of lamb, 19, 87, 93; parts of animal consumed, 13, 15, 16; sacrificial, 43, 70; uncut, 232, 278; of wild sheep, 200 
men: made, 214; 'our', 132, 142, 171, 185

mice, 111

Mighty Heaven, 113; see also Heaven

milk, 169; of ewes, 87, 93; (metaph.) of the heart, 254; mare's, 85, 87,

93; white, 167

milking: cows, 189; goats, 151, 152, 177; mares, 90, 145, 205; sheep, 189

month of the Roebuck, 282

moon: sun and, $\mathbf{1 8 9}$

mother: of Bekter, 60; of Belgünütei and Bügünütei, 18, 20; of

Belgünütei, Bügünütei and their half-brothers, 22, 23; of Belgütei, 60,

101, 112; of Börte, 94; of Ča'adai, 254; of ČQ, 76, 78, 83, 85, 87, 96,

118, 203, 214, 242, 243; of ČQ and his brothers, 74, 75, 76, 78, 242,

244; of Jamuqa, 201; noble, 74, 76, 78; of Ong Qan, 152; of Qabiči

Ba'atur, 43; of Qulan Qatun, 197; Tayang Qan, 189, 194, 196; title,

of respected women, and rivers, the earth, the sun: see Mother Alan,

and similar entries in the Name Index

Mother Earth, 113, 255

Mother Sun, 238

mothers and children, $\mathbf{7 2}, \mathbf{7 4}$; mothers and the older/younger brothers, $\mathbf{7 9}$ mountains, 147, 240, 247, 266, 276; shelter of, 208; see also hills; ridges mules: pack, 274; riding, 274

murder: of Bekter, 77, 78; of his brothers by Ong Qan, 150, 177, 181; of

Mongol envoys to the Sarta'ul, 254

Muslims: see Sarta'ul; also Sartaq in the Name Index

name giving: the Altan Qan [Ai-tsung] given the name Seüse, 273;

Ba'aridai, 41; Burqan Qan changed to Šidurqu, 267-8; clan names

Adargin, Barulas, Buda'at, 46; Jaăiradai, 40; Jebe, 147, 257; Jürkin,

139; Noyagidai, 46; Ong Qan, 134; Temüj̆in, 59; Temüǰin called

Činggis Qa'an (Qan), 123; see also epithets

nets: casting, 199; dragnets, 75, 199; hunting, 234

nightguards: companies of, 278; duties of, 192, 229, 232-4, 278 ; eighty,

191, 192, 224; elder, 230; and going on campaigns without partici-

pation of qan, 233, 278,; handed over to Ögödei, 269; number of, 229,

278; and judicial matters, 234; and movement in the vicinity of

Palace, 229; organization of, 191, 224, 225; passes, 229; powers of,

229; praise for, 230; and quivers, 225; recruitment to, 225;); and security of Palace, 229, 230, 232, 278; see also Guard; roster norm: see great norm

oaths, 108; against ČQ by sons of Toqto'a, 199; of friendship, 141; of loyalty, 123; of loyalty to ČQ by Ong Qan, 178; pricking of finger and, 178; of Quyildar, 208; of Sača Beki and Taiču, 136; as sworn friends, 116-17; see also alliances; pledges; promises; word 
oboq: see clans

occupations (long- or short-term, non-govermental): beggar, 214; carpenter, 223; concubine, 43, 112, 121; cowherd, 232, 234; door-keeper, 192, 232, 278; grainkeeper, 279, 280; groom, 192; herder of milch mares, 279, 280; lamb-herd, 118; shamans and soothsayers, 272; shepherds, 118, 124, 152, 222, 234; smith, 97; see also servants; slaves; stewards/cooks

offerings: to ancestors, 70; burnt, 161, 177; cattle, 272; food, 272; gold, 272; to Heaven, 44; to Ong qan's head, 189; people as, 272; silver, 272; substitute (of Tolui for Ögödei), 272; see also rites; sacrifices offspring of offspring, 204; of Badai and Kišiliq, 187; of ČQ, 103, 187, 201, 203, 208, 231; of Father Mönglik, 204; of the Merkit, 112; mothers and fathers down to of the Tang'ut, 268; of Muqali, 206; of Narin To'oril, 218; of Quyildar, 185, 217; of Sorqan Sira, 219; of the Tayiči'ut, 148; of those laying hands on rightful lord, 149, 200; see also kinship terms; relatives

old age: Ong Qan and, 164, 167

orders of ČQ; of Ögödei: see lengthy listings in RSH 2.1286-87

orphaned children, 272; bounty granted to, 185, 217, 218; of Quyildar: care of, 171; of Tolui: care of, 272

otčigin: 'yongest son', custodian of the family 'fire', i.e., the hearth, yurt, and by extension the family domain or apanage (RSH 1.288)

otter: dress from skins of, $\mathbf{1 1 4}$

oxen, 100, 101, 177, 255, 280; drum covered with hide of, 106; hornless and fallow, 121; hornless black, 214; red [bull], 240

pack-horses, 172; pack-mules, 274; pack-saddles, 172

Palace: in Black Forest (Tu'ula River), 264; at Dolo'an Boldaq of Köde'e Aral (Kelüren River), 282; female attendants of, 232; front of, 234; Great [= Qa'an's] Palaces, 272; left side of, 234, 278; moving and stationary, 233; movable, of Burqan Qan, 267; nightguards and administration of, 233; Palace tent: see tents; rear of, 234; right side of, 234, 278; security of, 229, 230, 232, 278; supervision of, 234; unauthorized entry into, 229, 278; see also tents

palisade/stockade: $\mathbf{7 9}, \mathbf{8 8}$; built by Tatars, $\mathbf{1 3 3}$

passes (mountain), 199, 240, 247, 254

pasture, 151, 170, 279; see also grazing grounds; plants

paternity: doubtful, 17-18, 20-1, 44, 254; see also Bodončar, Buqatu

Salǰi, Buqu Qatagi, J̌e'üredei, and J̌oči in the Name Index

patrols/patrolmen: ČQ's, 193, 195; Naiman, 188, 193, 194, 195; 'our',

158, 193, 195; observation posts, 142; sent out by Buyiruq Qan, 158; sent out by ČQ, 158, 170; sent out by ČQ and Ong Qan, 142; Tumat, 240; see also reconnoitring

peninsulas, 141

plains: see steppes 
plants: 'caragana' [marching order], 195; feather-grass, 249; grass, 177, 255, 281; great burnet, 74; saltwort, 105; sedge, 105; silverweed, roots of, 74; wild garlic, 74; wild leek, 75; wild lily, 74; wild onion, 74, 75; see also trees

pledges: of betrothal, 66; by Ong Qan and his brothers, 152; by Senggüm and others to seize ČQ, 169; see also oaths; word

plundering: of the Altan Qan [Ai-tsung], 273; of Batkesen, 257; of camp of Naratu Šitü'en, 135; enemy people, 179; of family and people of Ong Qan, 162, 163; of family and people of Toqto'a Beki, 157; by Jamuqa of own supporters, 144; of grainstores, 177; of the J̌ürkin, 136; of the Kitat, 272; of the Merkit, 109, 177, 198; of Olon Dongqayit, 187; of the Orusut, 274, 275; of peasants of Qan Melik, 257; of people of Toqto'a Beki, 109; of people of Aša Gambu, 265; of people on border of the Hindus by Bala, 264; of possessions of Dayir Usun, 117; of possessions of Toqto'a Beki, 117; of the Tang'ut, 265, 266, 268; of the Tatars, 134, 153, 154, 156; of the Tayiči'ut, 148; of the Tumat, 240; of wives and children of Toqto'a Beki, 109; see also abduction; robbery

poison: given to Yisügei Ba'atur by the Tatar, 67; perhaps also 281 post-relay system (horses, relay stations, etc.): $\mathbf{2 7 9 - 8 1}$

prayer: to Burqan Qaldun, 103; to Eternal Heaven, 240; Syriac, Abui babui, 174

principle of loyalty and mutual obligation; see great norm; services promises: of Burqan Qan to ČQ, 249, 256, 265; between Ong Qan and ČQ, 164, 177; of Ong Qan to ČQ, 104; of Yisügen Qatun to ČQ, 155; see also agreements; oaths; word

protection: given by Büri Bökö, 131; of Heaven and Earth, 125, 163,

177; of Heaven/Heaven Above, 145, 179, 187, 199, 203, 256, 265

proverbial sayings/old sayings/ancient words, 33, 55, 56, 66, 78, 118,

147, 164, 177, 255, 260, 277; mocking, 256, 265; not to be forgotten, 201; about requiting wrong, 58, 154, 214, 254; on sworn friendships, 117

punishment: see lengthy entry in RSH 2.1292

Qajaru Inerü sacrifice, 70; see also sacrifices

Qasar [Khazar] dog, 78

quagmires, 102

quda (term): of Yisügei, 62, 63, 65, 66, 69

quivers, 105, 190, 194, 195, 225, 229, 234, 279; awarding of to various

men, 124, 187, 219; of birch-bark, 230; of dayguards, 278; nightguards and, 225; striking, 194; taking away, 189, 190; of willow, 230

rafts, 105, 109;

rain, $108,205,214,230$; rainstorm conjured up by magic, 143

rats, 111, 124, 255 
rebuke: of Güyük by Ögödei, 277; of Önggür and Arqai Qasar by ČQ, 252; words of reproach, Jamuqa and Ong Qan, 108 reciprocity: see great norm reconnoitring, 38, 183, 185, 193, 208; establishment of scouts, 273, 281 recruitment, 191, 192; criteria for, of guards, 191, 224; of dayguards, 191; evasion of, 224; to guards, 224, 225; of nightguards, 191, 225; of quiverbearers, 225; requirements of recruits to guards, 224

Red Circle, day of, 81, 118; in Year of the Rat (1204), 193

Red Coats, 251

relatives: of Hö'elün, 61; male, Alan Qo'a without, 18; by marriage, see also kinship terms; offspring of offspring; quda

revelling and feasting: on renewal of friendship of ČQ and J̌amuqa, 117 revenge, 113; on Burqan Qan by ČQ, 267; on ČQ by the Merkit, 102,

111; on the Merkit by Belgütei, 112; on the Merkit/Sarta'ul by ČQ, 105, 199, 254; saying about taking, 58, 154, 214, 254; on Tatars for destruction of ancestors, 154, 214; on Tatars for slaying of Ambaqai Qa'an, 53, 58; on Tayiči'ut by ČQ, 76, 77, 78; see also RSH 1.540-43 reward for services: Alčidai, 242; Badai, 187, 219; Belgütei, 242; Boroqul, 214; Bo'orču, 205; Bo'orču and Muqali, 266; Ča'adai, 242; Čila'un, 219; Čimbai, 219; Doqolqu Čerbi, 124; Hö’elün, 242; J̌elme, 211; J̌etei, 124; J̌oči, 242; J̌ürčedei, 208; Kišiliq, 187, 219; Ögödei, 242; Ögölen Čerbi, 124; Önggür, 213; Qači'un Toqura'un, 124; Qasar, 242; Qorči, 121, 207, 241; Quyildar, 185; Sorqan Šira, 219; Šigi Qutuqu, 203; Taqai, 186; Tolui, 242; Tolun, 267; see also great norm

ridges, 56, 146, 147; at Altan Qorqan, 259; of Qara'un J̌idun, 183; see also hills; mountains

right wing, 104, 105, 198, 239, 258; Burqan Qan as ČQ's, 249, 256, 265; of Naiman-Önggüt army, 190

rites: pertaining to daughters-in-law, 189; see also offerings; sacrifices ritual: consecration of standards, 106; dancing around the Leafy Tree, 57; meal of Qajaru Inerü, 70; oath and exchange of gifts of sworn friendship, 116, 117; prostration and libation to sacred mountain, 103 rivers, 76, 199, 245, 254, 255; spirits of land and, 272; see also streams; and Mother Onan in the Name Index

robbery, 39; of clothes, $\mathbf{1 3 6}$ of the eight horses, 90; of goods of Jungdu by Qada, 252; of horses, 188, 205, 245; of horses, Čoči (Joči) Darmala and Taičar from each other, 201; of horses of Joči Darmala, 128; judging, 154, 203; of livestock, 39; of Ong Qan's people, 177; of tether, 131; see also plundering

roebuck: knucklebone, 116; month of the, $\mathbf{2 8 2}$

roster: of dayguards, 191, 192, 224, 227, 229, 278; of guards, 278 of nightguards, 191, 192, 224, 229, 278; of officials, 192; of quiverbearers, 229, 278; of stewards, 229 
rulers, 21, 74; Ambaqai Qa'an, 52; ČQ, 248; Qabul Qa'an, 52; of ČQ's people, 180; decree of Eternal Heaven on, 244; impossibility of there being two, 189; queen Gürbesü, 189; suitability of Tayang Qan as, 189; wife suitable for, 155

sable: black, 239; catchers, 109; coat, 96, 104; hunting of, 9, 249; swaddling clothes, 97, 211; trade in, 182; waistcoat lined with, $\mathbf{1 3 5}$ sacrifices: to Burqan Qaldun, 103; to the dead, 161, 177; „̌̈̈geli, 43; to Ong Qan's head, 189; of stallion and mare, 141; to standards, 106, 193; of Tolui for Ögödei, 272; see also under offerings; Qaǰaru Inerü; rites

saddles, 80, 87, 97, 199, 229, 245, 254, 278; flaps, 105; girth, 80; gold, 184; poor, 193; strap, 158; see also under pack-horses

Sarta'ul: murder of Mongol envoys to, 254; revenge on by ČQ, 254; subjugation and submission of, 260, 263, 265

scouts: see reconnoitring

sea, 245; coast, 253; see also Tenggis in the Name Index

servants: of Bodončar and his brothers, 39; in camp of ČQ, 198; of ČQ, 100; of Dobun Mergen, 16; as dowry, 43, 208; of Hö'elün, 98; of Ibaqa Beki, 208; Jirgin boys, 185; Jirgin girls, 185; of Naiman, Mongol daughters, 189; of Ong Qan given to Badai and Kišiliq, 187; 'our', 198; of Quyildar's kin, Jirgin to be, 185; retainers, 123, 146, 219; seizing master, 200; sons and daughters of the Jüuin, 266; of Toroqolj̄in Bayan, $\mathbf{3}$

service: child sold/given into, 15-16, 97; see also freeman; servants; slaves

services: of Boroqul et al. to Hö'elün, 214; of Boroqul to ČQ, 214; of ČQ and Ong Qan to Altan Qan [Chang-tsung], 134; of Father Mönglik to $\check{C} Q, 204$; of Jamuqa to ČQ, 200; of J̌elme to ČQ, 145; of J̌̈üčedei to Č, 208; offers of, 149, 185, 220; principle of loyalty in providing, 281; principle of rewarding, 208; of Quyildar to ČQ, 185; of Sorqan Šra and his sons to ČQ, 146; of Šigi Qutuqu to ČQ, 203

settled peoples: distinguished from nomadic, 203; Tangut Hsi Hsia, 249, 265

shafts, of cart: 56, 200, 214; second of two, 177, 186, 214; under tent, 121

shamans, 181, 272; and soothsayers, 272; see also ritual; super-natural sheep, 100, 195, 280; brown, 124; Degei in charge of, 124; droppings, 111; ewes, milk of, 87, 93; sheep-fold, 124; levies of, 279; milking of, 189; pied, 124; Sartaq, 181; shearing, 100; sheep-pen, 195; trading, 182; wethers, 124, 182, 272, 280; wild, 200; and wolves, 195

shelter: for Čilger Bökö, 111; of elm twigs, 103; of feather-grass, 249; in high places, 190; for horse-herders, 118; Jü̈rčedei as for ČQ, 208; for sparrow, 85; Sübe'etei and Büǰek as for Güyük, 277; Sübe'etei as, for ČQ, 124; tree as, 174 
shepherds, 118, 124, 152, 222, 234

sickness: epidemics in north China, 248; of ČQ (fever), 265; and failure of guard to take turn of duty, 227, 278; of Ögödei, 272; spirits and,

146, 272; see also sacrifices; wounds

sky: starry, 254

slander, 164, 177; Adarkidai and, 46; of ČQ by J̌amuqa, 160, 166; of ČQ

by Senggüm, 167; of Qasar by Kököčü Teb Tenggeri, 244, 246

slaves, 180, 232, 273; of the door/threshold, 137, 180, 211; given to

family of Boroqul, 241; Gü'ün U'a offers his sons as, 137; Merkit

women made, 112; personal, 137, 269; seizing master, 200; Tatars to

be made, 154; see also servants

snakes, 102; fangs of, 164, 177; see also dragon-snake

sons (= grandson): of Ča' adai, 270

spears, 72, 170, 195; nightguards and, 232, 278; steel, 106

spine: Büri Bökö's broken, 140; Old Čaraqa speared in, 72; Taičar shot in, 128

spirits (lords, rulers): of land and rivers, 272

spitting: of blood, $\mathbf{1 4 5}, 152$

spring (season), 19, 27, 70, 116, 168; of Year of the Hen (1225), 264; of

Year of the Ox (1205), 198; of Year of the Pig (1203), 166

stallions: sacrifice of, $\mathbf{1 4 1}$

standards: black and multicoloured, 170; of ČQ, 193; of Jamuqa, 106; long, 106; nightguards and, 232, 278; war, 181; white with nine tails,

202; Yisügei's, held by Hö'elün, 73

stars, 193, 194

starvation: of Kitat troops, $\mathbf{2 5 1}$

steppes, 56, 123, 179, 195, 205

stewards/cooks, 130, 136, 192, 208, 213, 252; appointment of, 124; and distribution of food, 213; and drinking, 124, 130; duties of, 229; of Ibaqa Beki, 208; roster of (see under roster)

storehouses: for land-tax grain, $\mathbf{2 7 9}$

streams, 56; see also rivers

strength/power: of Eternal Heaven, 275; increased by Eternal Heaven,

199; increased by Heaven and Earth, 113, 125, 208, 224, 260

strongholds: Taiqal, 198

succession: to Ambaqai Qa'an, 53, 57; collateral, 52; by nomination, 57;

to Ong Qan, 164, 167; to Qabul Qan, 52; by will, 52

succession to ČQ, 245, 254-5; Ögödei and, 255, 269, 272

successors: of ČQ, 245; and Badai and Kišiliq, 187; and the Guard, 231;

Ögödei declared, 255, 269, 272; of people under Ong Qan, 152; and place of Ibaqa Beki, 208; and register of decisions on judicial matters, 203; threat to, 245; of Ong Qan, 164, 167; of Ögödei, 255

summer, 177; ČQ spends at ridge of Altan Qorqan, 259; ČQ spends on Časutu Mountain, 266; ČQ spends on river Erdiš, 264; Red Circle day, 81, 118, 193; summer quarters of the Soltan, 259 
supernatural/spiritual/occult matters: divination, 272; dreams, 63, 201, 219; events, 21; magic/spells: 143, 174, 189, 272; omens/portents/ signs/prophecies: 80, 121, 189, 201, 206, 207, 244; shamans/soothsayers, 181, 272; spirits of land and rivers, 272; submission to superior power, 103

surprise attack: of ČQ on Ong Qan, 185, 208; of Dörbei Doqšin on Tumat, 240; of Tumat on Boroqul, 240

swords, 50, 131, 170, 195, 270; awarded to Qubilai, Čilgütei, Qarqai

Toqura'un and Qasar, 124; execution by, 136; hilted, 106 sworn friends, 117; ČQ and J̌amuqa, 105, 106, 110, 113, 116-17, 118,

$125,127,160,166,170,179,181,195,196,200,201$; ČQ and Quyildar, 171, 208, 217; ČQ and Senggüm, 181, 204; and exchange of gifts and oaths of, 116-17; Yisügei and Ong Qan, 96, 104, 150, 151, 164, 177; see also friendship

tactics: see manoeuvres/tactics

tails: of horse, $\mathbf{2 4}, \mathbf{2 6}, \mathbf{7 6}, \mathbf{7 7}, \mathbf{7 8}, \mathbf{9 0}, \mathbf{1 1 7}, \mathbf{1 2 5}, \mathbf{1 2 9}, \mathbf{1 5 2}, \mathbf{1 7 7}$; nine, of standard, 202; of Sartaq sheep, 181; wooden, 275

taxation: of Baqtat people, 274; raising of to provide for Ong Qan, 151,

152, 177; reform of by Ögödei, 279; see also land tax; levies tenggeri: see Heaven tent-carts, 121, 124; of the Palace, 232, 233, 234, 278 tents, 56, 68, 73, 78, 84, 85, 86, 90, 100, 124, 177, 203, 242, 246; back/rear of, 165, 169, 229, 278; of ČQ, 93, 169, 245, 267; centre of the tent, 213; domestics and servants in, 124; eastern side, 214; of Father Mönglik, 168, 204; for feast, 275; felt-girt, 230; felt-walled, 202, 203, 230; golden of Ong Qan, 152, 184, 185, 187; great council in single, 154; grey, 245; guarding of ČQ's, 192; hierarchy of places within, 165; of Hö'elün, 98, 138, 214; latticed, 230; of Naqu Bayan, 93, 205; Palace, 230, 232, 278; palatial, 123, 177, 190; place of honour in, 165; pulled by ox, 121; rock the size of, 80 ; serving inside, 224; smoke-hole of, 21, 105, 109, 240, 246; of the Tang'ut, 265, 266; of Tayang Qan, 193; of thin woollen cloth, 184, 265, 266; of Toqto'a, 105; of Toqto'a Beki, 109; travel-tents, 169; vented, 230; of Yeke Čeren, 169

textiles: see cloth

thirst, 254; from wound, 145

thorns: in inner lapel of coat, 201; in mouth, $\mathbf{7 7}$

threshold, 245; golden, 137; royal, 203, slaves of, 137, 180, 211

Tibetan dogs: used figuratively, $\mathbf{2 6 0}$

tools: see implements

torture: questioning of Naya'a, 197

towns, 247, 258; border, 253; of Qan Melik, 257; Kitat, 272; subjugated,

253; with walls of pounded earth, 203, 249, 265; see also cities tracking, 56, 88, 90, 101, 103, 172, 183; red bull, 240 
transport: see camels; carriages; carts; horses; rafts trapping: of hawks, 25

trees: aspen, 115; birch, casket/quiver made from, 178, 230; chopped, hewn and sawn, 240; cypress, 245; elm, 103; fir, bows made from, 116; juniper, tip of arrow, 116; old, 245, 254; peach, bark of wild, 106; pine, 245; spruce, 74, 115; willow, 103, quivers made from, 230; see also fruit

tribute: paid by Tang'ut to ČQ, 249; paid by the Altan Qan [Hsüantsung] to ČQ, 248

troops: see army; Guard; units of a thousand; units of ten thousand; see also RSH 2.1308

units of a thousand, 191, 192, 202, 203, 209, 221, 222, 223, 224, 225, 231; Baya'ut, 213; of dayguards, 226; formed from unregistered households, 222; Ikires, 202; and levy of mare's milk, 279; and levy of sheep for support of the qan and the poor, 280; and levy to support post-station system, 280; Mongol, 202; of nightguards, 226; Onggirat, 202; Önggüt, 202; post-station masters and post-horse keepers from, 279; of quiverbearers, 225, 226; selection of campmasters from, 279 units of ten thousand, 104, 105, 106, 107, 108, 129, 224; of the centre, 220; of the left wing, 206, 220; of nightguards, quiverbearers and dayguards, 224; of Qorči, 207; of the right wing, 205, 220; and the thirteen camps, 129; see also cmdrs.

valleys, 56, 247

vengeance: see revenge

virginity test: on Qulan Qatun, 197

walls, brick: 279

warnings: of Ambaqai, 53; Badai and Kišiliq warn ČQ, 169, 170;

Belgütei warns $\breve{C Q}$ about rupture with the Jürkin, 131, 132; Börte warns ČQ, 245; Čigidei and Yadir warn ČQ, 170; Father Mönglik warns ČQ, 168; from Heaven, 80; J̌amuqa warns ČQ, 170, 200

war(s) and warfare: see campaigns against; manoeuvres/tactics washing hands, 189

water, 272; depth of and death, 277; mixed with curds, 145 ; provision of

by digging of wells, 279, 281; river, $\mathbf{2 3 8}$; searching for, $\mathbf{1 8 8}$

watering (animals), 183, 208; of wethers, $\mathbf{1 8 2}$

weapons, 234, 240, 254, 279; see arrows; bows; spears; swords

wells: digging of, 279, 281

Western Campaign: see under campaigns

wet, 207, 213; see also rain

wheels: calf tied to, 194; of cart, 177

widows: of Ambaqai, 70, 71; Hö'elün as, 74; of Tolui, 272; of Yisügei, 68 
wife-to-be: of ČQ, 66; of Yeke Čiledü, 54; see also bride wine, ceremonial: 154; drunk at parting feast, 275; drunk at sacrifice to Ong Qan's head, 189; permission to drink, 187, 219 wisdom, traditional: see proverbial sayings wives: of Ambaqai Qa'an, 70; attitude towards, 155; of blue-grey wolf, 1; of Bodončar, 43, 121; of Borjigidai Mergen, 3; of Boroqul, 214; of Bo'orču and Muqali, 266; confiscation of, 123; Čaraqai Lingqu, 47; of Č, 96, 104, 105, 155, 186, 196, 208, 257, 265; of Daiduqul Soqor, 240; of Dei Sečen, 94; of Dobun Mergen, 9; of Inanča Bilge Qan, 189; of J̌amuqa, 201; of Jürčedei, 208; of Kököčü, 188; many: of Čiduqul Bökö, 41; of the Merkit (made concubines and slaves), 112; of Način Ba'atur, 46; principal, 155; of Qorči, 241; of Qorilartai Mergen, 8; of Qutu, 198; secondary, 130; of Senggüm, 162, 163, 177; thirty: request of Qorči for, 121, 207; of Tolui, 186; of Toqto'a Beki, 157; of Toroqolǰin Bayan, 3; unfaithful, 188; of Yeke Čeren, 169; of Yisügei, second, 60; see also betrothal; widows; wife-to-be

wives and children: of Qada'an Daldurqan, 174; of Qasar, left with Ong qan, 183; of Quyildar, 185; of Sorqan Šira, 146; of Sügegei J̌e'ün, 181; of Toqto'a, 105; of Toqto'a Beki, plundered, 109

wolves, 26, 78, 210; blue-grey wolf, 1; and sheep, 195

womb: of Alan Qo'a, 21, 22; of Börte, 254; of captured wife of Bodončar, 121; of Hö'elün, 78, 244; water, 121

women: as booty, 198; attendants of the Palace, 232; Botoqui Tarqun given to Quduqa Beki, 241; danger to from soldiers, 197; distribution of captured, 207; with dog's face, 188; as dowry, 41; fate of as prisoners, 112; governing Tumat, 240; merit of acknowledged in the saving of Tolui, 214; old, 275; pregnant, 38, 40, 1941; for the qan, 123, 197; role of, 118, 138, 169, 189, 214, 244, 245; splendid, 115; taken by Qorči, 207; Tayang Qan like, 194; thirty, requested by Qorči, 121, 207, 241; without principle, 281

word, keeping of: by Altan and Qučar, 127, 255; by Burqan Qan to ČQ, 249, 268; by J̌oči and Ča'adai, 255; by Sača Beki and Taiču, 136; by Altan, Qučar and Sača Beki, 123; by ČQ and Muqali, 206; by ČQ and Ong Qan, 164; by ČQ to Father Mönglik, 246; by Senggüm and others to seize ČQ, 169; poisonous, 267; remiss in one's, 108, 255; of a woman without principle, 281; see also agreements; promises; 'yes' wounded: standing guard over, 171, 172, 174 wounds: cauterized, 173 ( $c f$. RSH 1.528-29); of ČQ, 145; of Ögödei,

173, 214; of Senggüm, 171, 174, 208; of Quyildar, 175 wrestling, 254; Belgütei and, 131; Belgütei and Büri Bökö, 140; Temüge and Kököčü Teb Tenggeri, 245

writing: book, 282; blue-script register of judicial decisions in book with white paper, $\mathbf{2 0 3}$

Year of the Dog: 1202, 153, 157; 1214, 251; 1226, 265 
Year of the Dragon: 1208

Year of the Hare: 1207, 239; 1219, 257; 1231, 272

Year of the Hen: $1201, \mathbf{1 4 1} ; 1225, \mathbf{2 6 4}$

Year of the Horse: 1210

Year of the Ox: $1205, \mathbf{1 9 8}, \mathbf{1 9 9} ; 1217 ; 1229$

Year of the Pig: $1203, \mathbf{1 6 6} ; 1215 ; 1227, \mathbf{2 6 8} ; 1323$

Year of the Rat: $1204, \mathbf{1 9 3}, \mathbf{1 9 7} ; 1216 ; 1228, \mathbf{2 6 9} ; 1240 ; 1252 ; 1264$; 1324; and composition of SH, 282

Year of the Sheep: 1211, 247, 250

Year of the Snake: $1209 ; 1233$

Year of the Tiger: $1206, \mathbf{2 0 2} ; 1218$

'yes': friend of the word, 255; remiss in one's, 108; see also oaths; word younger brother: = cousin, 120, 124; = nephew, 272

younger brothers, 166; behaviour towards elder brothers, 76; of Buqu Qatagi, 30; of children of Hö'elün, 135; of cmdrs. of a hundred, 191; of cmdrs. of a thousand, 191; of Ča'adai, 269; of Čiledü, 111; of ČQ, 76, 79, 83, 85, 87, 93, 201, 203, 242, 245, 254, 257; of Degei, 124; of Du'a Soqor, 5, 6; of Hö'elün's children, 203; J̌amuqa, 105; J̌amuqa without, 201; late-born, 203; of Ong Qan, 107, 151, 152, 164, 177, 186; of ordinary people, 191; of Qurčaqus Buyiruq Qan, 150; reason for calling To'oril, 180; of soldiers, 101; of Tarqutai Kiriltuq, 149; term used figuratively, 68; title of J̌amuqa, 104, 108, 170; title of To'oril, 180; of Tolui, 272; of Toqto'a Beki, 111; of Yisügei Ba'atur, 54, 56, 242 


\section{LITERATURE AND ABBREVIATIONS}

The enormous literature on the Secret History is well documented in the second and third volumes of de Rachewiltz's work of 2004-2013. The listing below is quite different, including just (a) items earlier mentioned in the present work, and (b-c) some additional items of possible interest to those for whom this shortened version of the first de Rachewiltz volume is primarily intended. Any reader with special interests is encouraged to go to the original volumes (RSH 2.1088-1194 and 3.151-186) in search of further titles.

In the list here, underlining marks an abbreviation as the one used in RSH; any other abbreviation is the one used above.

(a) Works cited above ${ }^{1}$

Cleaves, Francis Woodman: The Secret History of the Mongols, for the First Time Done into English out of the Original Tongue and Provided with an Exegetical Commentary, I (Translation). Cambridge MA: Harvard University Press, 1982 [but completed in 1956; no more published]. Abbrev. Cl, Cl-82

de Rachewiltz, Igor: 'The Dating of the Secret History of the Mongols - A Reinterpretation', pp. 150-184 in UralAltaische Jahrbücher, NF 22 (2008). de Rachewiltz 2008, R-08

de Rachewiltz, Igor: 'Qan, Qa'an and the seal of Güyüg', pp.

272-281 in Documenta Barbarorum (Klaus Sagaster and Michael Weiers, eds.); Veröffentlichungen der Societas

${ }^{1}$ For a discussion of the Chinese primary and secondary sources on the Secret History, besides the Introduction to $\mathrm{RSH}$ the reader should consult Hung-51 and the Introduction to the Cleaves volume here cited. 
Uralo-Altaica 18. Wiesbaden: Harrassowitz, 1983. de Rachewiltz 1983, R-83

de Rachewiltz, Igor: The Secret History of the Mongols: A Mongolian Epic Chronicle of the Thirteenth Century. Translated with a historical and philological commentary. Vols. 1-2, Leiden: Brill, 2004, repr. 2006. Vol. 3 (Supplement), Leiden: Brill, 2013. RSH

Fletcher, Joseph: 'The Mongols: Ecological and Social Perspectives', pp. 11-50 in Harvard Journal of Asiatic Studies 46 (1986). Fletcher 1986. Also available in Studies on Chinese and Islamic Inner Asia (collected papers of Fletcher, edited by Beatrice Forbes Manz). Aldershot, Great Britain; Brookfield VT: Variorum, 1995.

Haenisch, Erich: Manghol un niuca tobca'an (Yüan-ch 'ao pishi). Die Geheime Geschichte der Mongolen aus der chinesischen Transkription (Ausgabe Ye Têh-hui) im mongolischen Wortlaut wiederhergestellt. Leipzig: Harrasowitz, 1937 (vol. 1), 1939 (vol. 2, Wörterbuch); repr. Wiesbaden: Steiner, 1962. $\underline{\mathrm{H}}$

Haenisch, Erich: Die Geheime Geschichte der Mongolen. Aus einer mongolischen Niederschrift des Jahres 1240 von der Insel Kode'e im Keluren-Fluss erstmalig übersetzt und erläutert. Zweite verb. Auflage, Leipzig: Harrassowitz, 1948. Ha This was re-edited with added marking of poetic passages in the otherwise unaltered text: Die Geheime Geschichte der Mongolen, herausgegeben von Walther Heissig nach der Übersetzung von Erich Haenisch. Düsseldorf-Köln: Diederichs, 1981, 1985. HH Kuribayashi, H., \& Choijinjab: Word-and Suffix-Index to the Secret History of the Mongols Based on the Romanized Transcription of L. Ligeti. CNEAS Monograph Series 4. Sendai: Tohoku University, 2001. [Includes photographic reproduction of $\mathrm{Y} 2$, the $\mathrm{Ku}$ certified copy of the text.] KCI, Kuribayashi 2001

Lattimore, Owen: 'Chinggis Khan and the Mongol Conquests', pp. 55-68 in Scientific American 209:2 (Aug. 1963). Lattimore $1932 \mathrm{~b}$

Man, John: Genghis Khan; Life, Death, and Resurrection. Revised and updated. London: Transworld/Bantam, 2011. GKLDR 
Man, John: The Mongol Empire: Genghis Khan, His Heirs and the Founding of Modern China. London: Transworld/ Bantam, 2014.

(b) Other publications on Činggis Qan, the Secret History, and early Mongol society

Bawden, Charles R.: Confronting the Supernatural: Mongolian Traditional Ways and Means. Collected Papers. Wiesbaden: Harrassowitz, 1994. CTS

Bawden, Charles R., tr., The Mongol Chronicle Altan Tobči. Göttinger Asiatische Forschungen 5. Wiesbaden, 1955. MCAT

Bira, Shagdaryn: Mongolian Historical Writing from 1200 to 1700 , translated from the original Russian by John $R$. Krueger and revised and updated by the author, $2^{\text {nd }}$ edition. Studies on East Asia 24. Bellingham: Western Washington University, 2002. MHW

Boyle, John Andrew, tr.: Rashīd al Dīn: The Successors of Genghis Khan. New York: Columbia University Press, 1971. Successors

de Rachewiltz, Igor: 'Father Antoine Mostaert's Contribution to the Study of The Secret History of the Mongols and the Hua-i i-yü', pp. 93-109 in vol. 1 of Klaus Sagaster, ed.: Antoine Mostaert (1881-1971) C.I.C.M. Missionary and Scholar. Louvain Chinese Studies 4. Leuven: K.U. Leuven, 1999. de Rachewiltz 1999b

de Rachewiltz, Igor, et al., eds.: with the assistance of M. Wang, In the Service of the Khan: Eminent Personalities of the Early Mongol-Yüan Period (1200-1300). Asiatische Forschungen 121. Wiesbaden: Harrassowitz, 1993. ISK

de Rachewiltz, Igor: 'Heaven, Earth and the Mongols in the Time of Cinggis Qan and His Immediate Successors (ca. 1160-1260) - A Preliminary Investigation', pp. 107-139 in Golvers \& Lievens, eds.: A Lifelong Dedication to the China Mission: Essays Presented in Honor of Father Jeroom Heyndrickx, CICM. Leuven Chinese Studies 17. Leuven: K.U. Leuven, 2007. de Rachewiltz 2007 LDCM Franke, Herbert: From Tribal Chieftain to Universal Emperor and God: The Legitimation of the Yüan Dynasty. Munich: Bayerischen Akademie der Wissenschaften, 1978. $\underline{\text { FTC }}$ 
Hung, William: 'The Transmission of The Book Known as The Secret History of the Mongols', pp. 433-492 in Harvard Journal of Asiatic Studies 14 (1951). Hung-51

Kara, György: Books of the Mongolian Nomads: More than Eight Centuries of Writing Mongolian. First English edition, tr. from the Russian by J.R. Krueger; rev. and expanded by the author. Indiana University Uralic and Altaic Series 171. Bloomington IN: Research Institute for Inner Asian Studies, 2005. BMN

Kuribayashi, H. comp.: Word- and Suffix-Index to the Hua-yi Yiyü Based on the Romanized Transcription of L. Ligeti. CNEAS Monograph Series 10. Sendai: Tohoku University, 2003. [Includes photographic reproduction of the text.] KIYG (See RSH 3.165 for other pertinent books in this series.)

Lattimore, Owen: Studies in Frontier History. Collected Papers 1928-1958. London: Oxford University Press, 1962. SFH Martin, Henry D.: The Rise of Chingis Khan and His Conquest of North China, ed. by E. Lattimore. Baltimore: Johns Hopkins Press, 1950; repr. New York, 1977. Martin

Pelliot, Paul: Notes on Marco Polo, I-III. Paris: A. Maisonneuve, 1959-73. NMP (See esp. entry on 'Cinghis' in 1:281-363.)

Pelliot, Paul, and Louis Hambis, Histoire des campagnes de Gengis Khan. Cheng-wou ts'in-tcheng lou, I. Leiden: Brill, 1951; II. by L. Hambis (unpublished manuscript). $\underline{\mathrm{HCG}}$

Ratchnevsky, Paul: Genghis Khan. His Life and Legacy, tr. by Thomas N. Haining. Oxford, 1991. (14 ${ }^{\text {th }}$ edition, with new introduction, 2006). $\underline{\text { ĆK }}{ }^{2}$

Rykin, Pavel: 'The System of Kinship and Affinity Terms in Middle Mongolian', pp. 25-47 in Acta Orientalia Academiae Scientiarum Hungaricae 64 (2011). Rykin 2011

Sverdrup, C.: Military Campaigns of Cinggis Qan and Sübe'etei. Oxford: Helion \& Co., 2016 (in preparation).

Thackston, Wheeler M., tr.: Rashiduddin Fazlullah: Jami 'u'tTawarikh (Compendium of Chronicles): A History of the Mongols, I-III, Cambridge, Mass., 1998-99 ['a smooth and readable version...[;] not very reliable however' (RSH 3.17). $\underline{\text { RFJT }}$ 
Vladimirtsov, Boris Ya.: Gengis-Khan, tr. by Michel Carsow. Paris: Librairie d'Amérique et d'Orient Adrien-Maisonneuve, 1948. GKV

Vladimirtsov, Boris Ya.: Le régime social des Mongols. Le féodalisme nomade, tr. by Michel Carsow. Paris: Librairie d'Amérique et d'Orient Adrien-Maisonneuve, 1948. Vlad. $^{2}$ Žamcarano, C. Ž.: The Mongol Chronicles of the Seventeenth Century, tr. by Rudolf Loewenthal. Göttinger Asiatische Forschungen 33. Wiesbaden: Harrassowitz, 1955. Žamc. $^{2}$

(c) Other publications on Inner Asia

Allsen, Thomas T.: Mongol Imperialism. The Policies of the Grand Qan Möngke in China, Russia, and the Islamic Lands, 1251-1259. Berkeley: Univ. of California Press, 1987. MI

Amitai, Reuven, \& Michal Biran, eds.: Mongols, Turks and Others: Eurasian Nomads and the Sedentary World. Leiden: Brill, 2005. MTO

Atwood, Christopher P., Encyclopedia of Mongolia and the Mongol Empire. New York: Facts On File, Inc., 2004. [688 pp., with 17 maps]

Dardess, John W.: Conquerors and Confucians: Aspects of Political Change in Late Yüan China, New York and London: Columbia University Press, 1973. CCo [Also Taipei, Taiwan: Rainbow-Bridge, 1974.]

Dardess, John W.: 'From Mongol Empire to Yüan Dynasty: Changing Forms of Imperial Rule in Mongolia and Central Asia', pp. 117-165 in Monumenta Serica 30 (1972-73). Dardess 1972/73

Grousset, René: The Empire of the Steppes: A History of Central Asia (translated from the French by Naomi Walford). New Brunswick NJ.: Rutgers University Press, 1970.

Hok-lam Chan, The Fall of the Jurchen Chin: Wang E's Memoir on Ts'ai-chou under the Mongol Siege (1233-1234), Stuttgart: E. Steiner, 1993. FJC

Lattimore, Owen: Inner Asian Frontiers of China, Boston, 1962. $\underline{\mathrm{IAFC}}$

Moule, Arthur C.: Christians in China Before the Year 1550. London: Society for Promoting Christian Knowledge, 1930; repr. Taipei, 1972. $\underline{\text { CC }}$ 
Sinor, Denis: Inner Asia: History-Civilization-Languages. A Syllabus. 2nd rev. edition. Uralic and Altaic Series 96. Bloomington IN, 1979, 1987; repr. Richmond (Surrey): Curzon, 1997. IA 


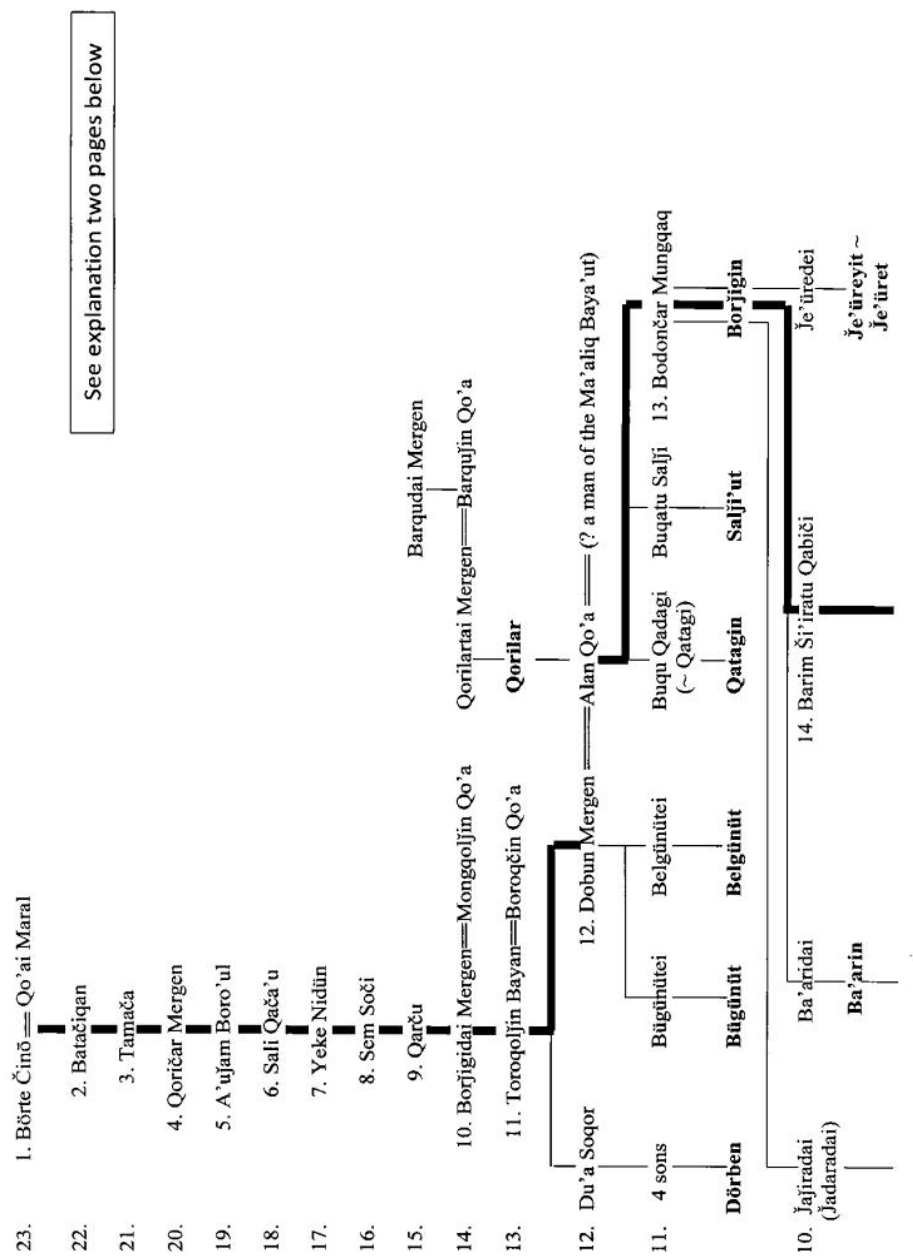




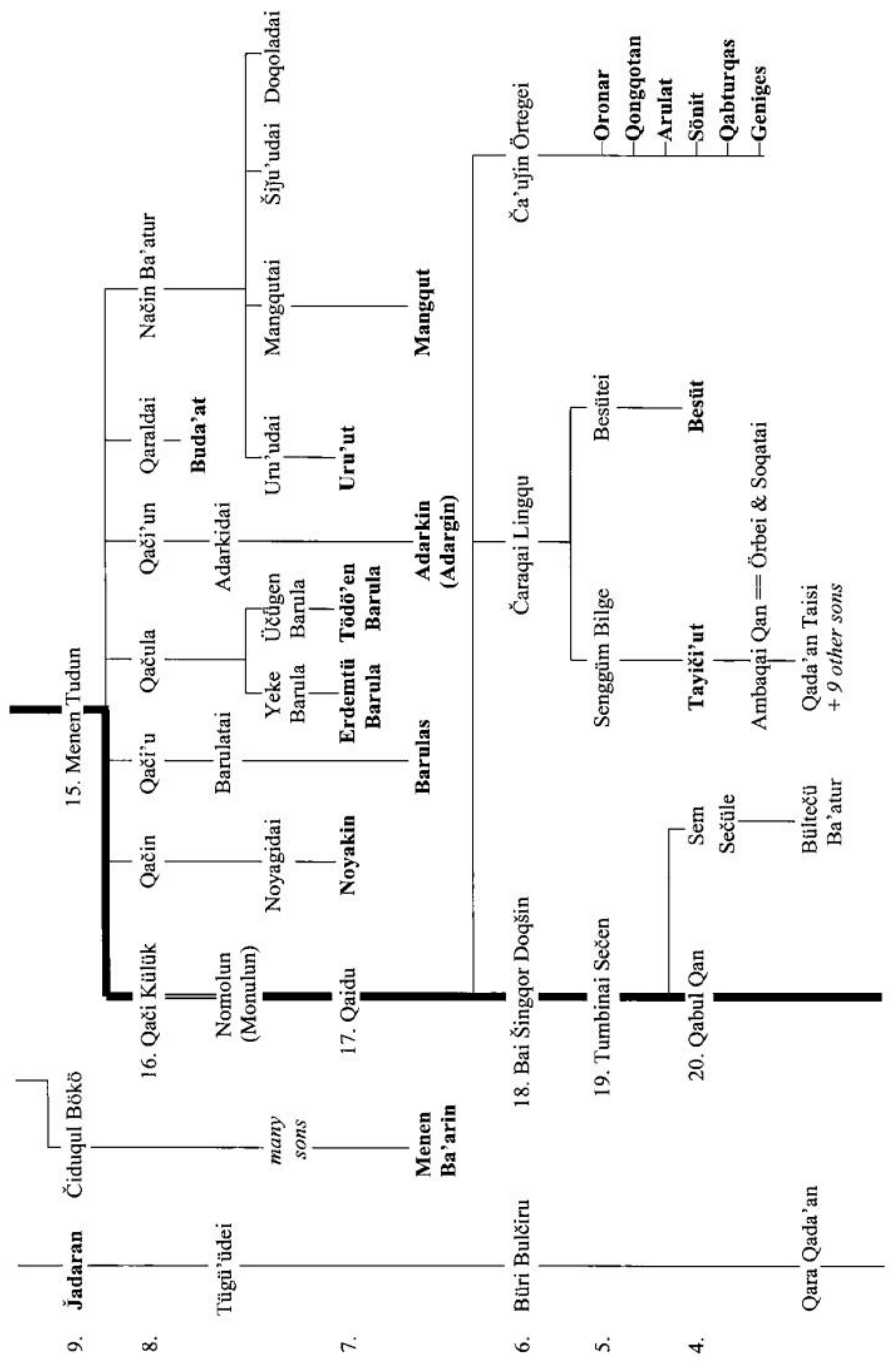




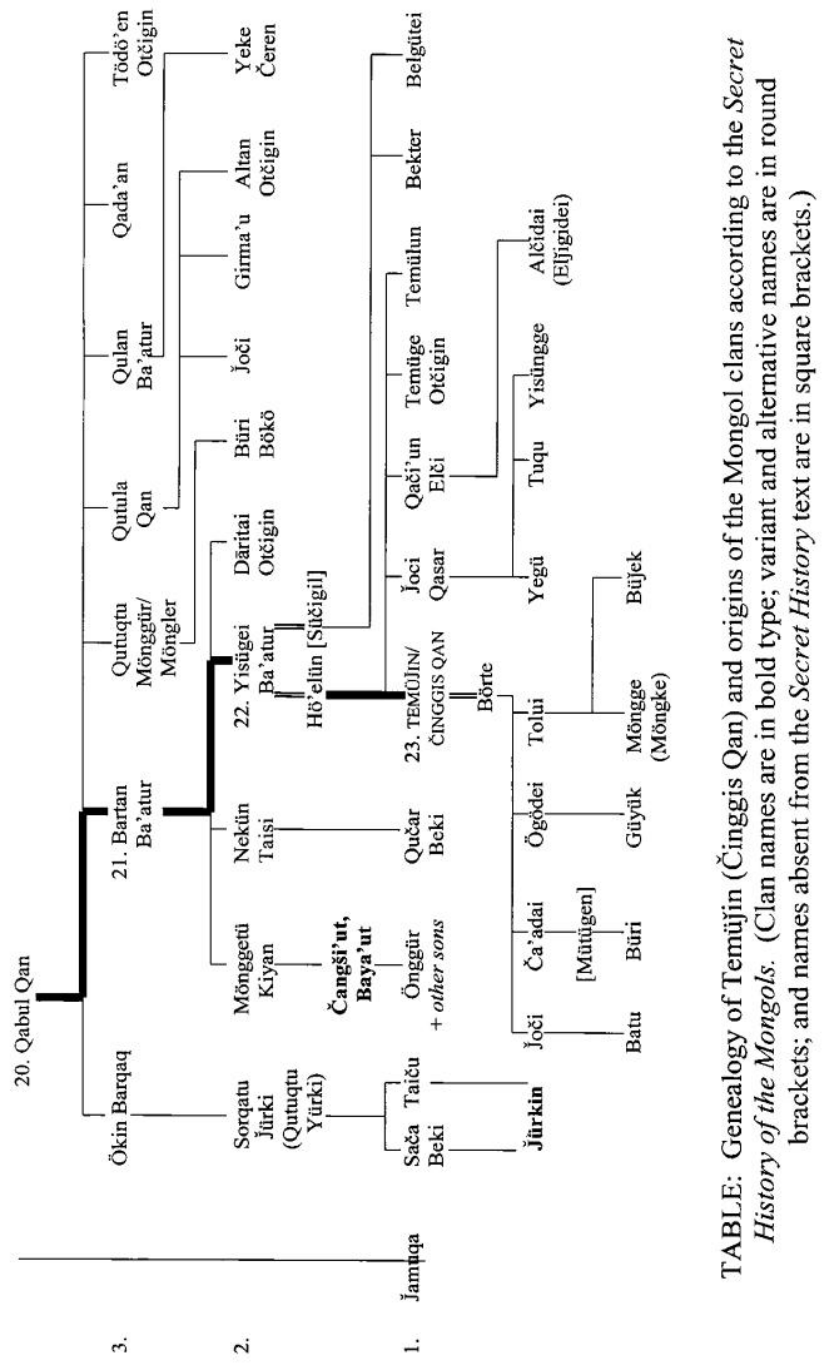





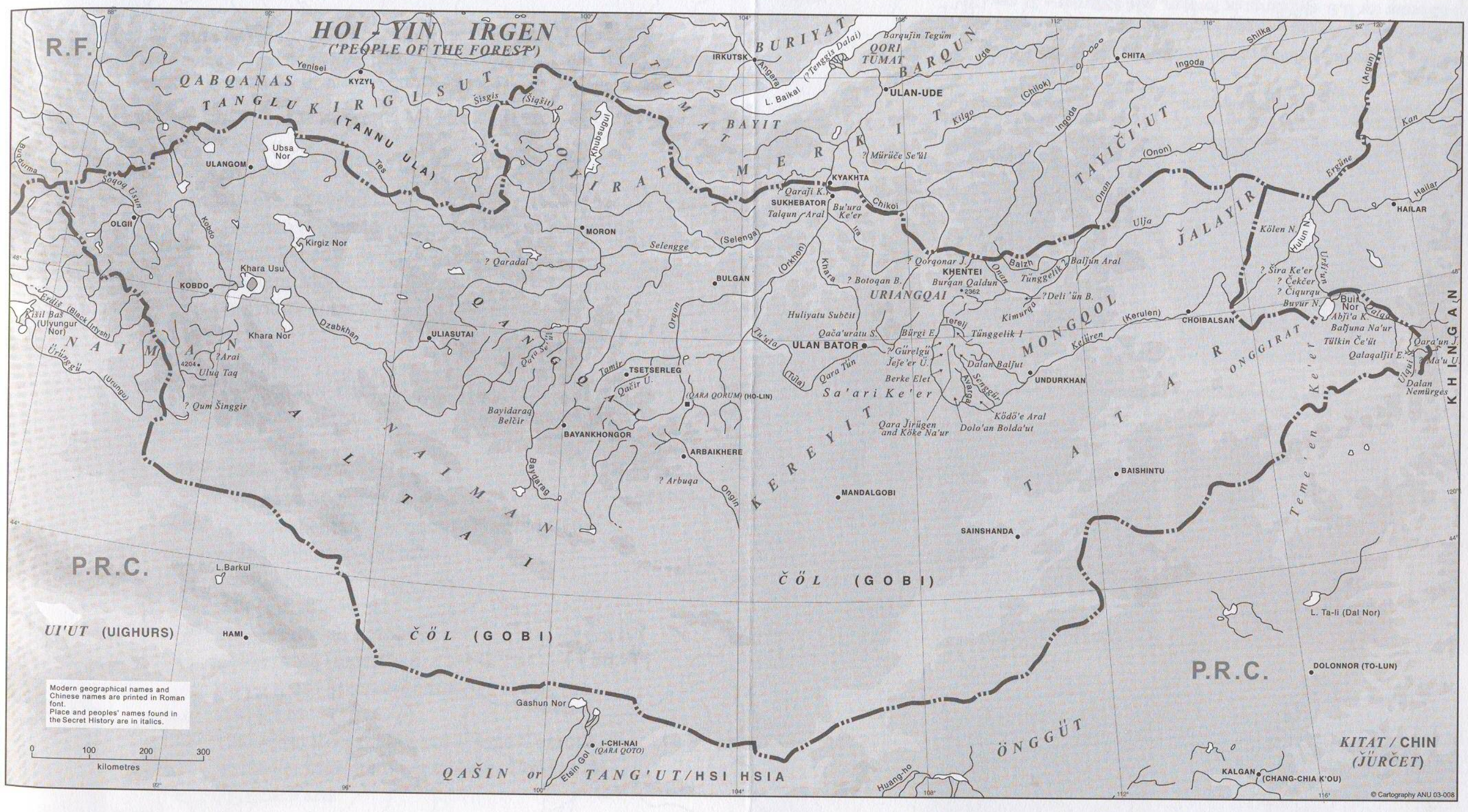




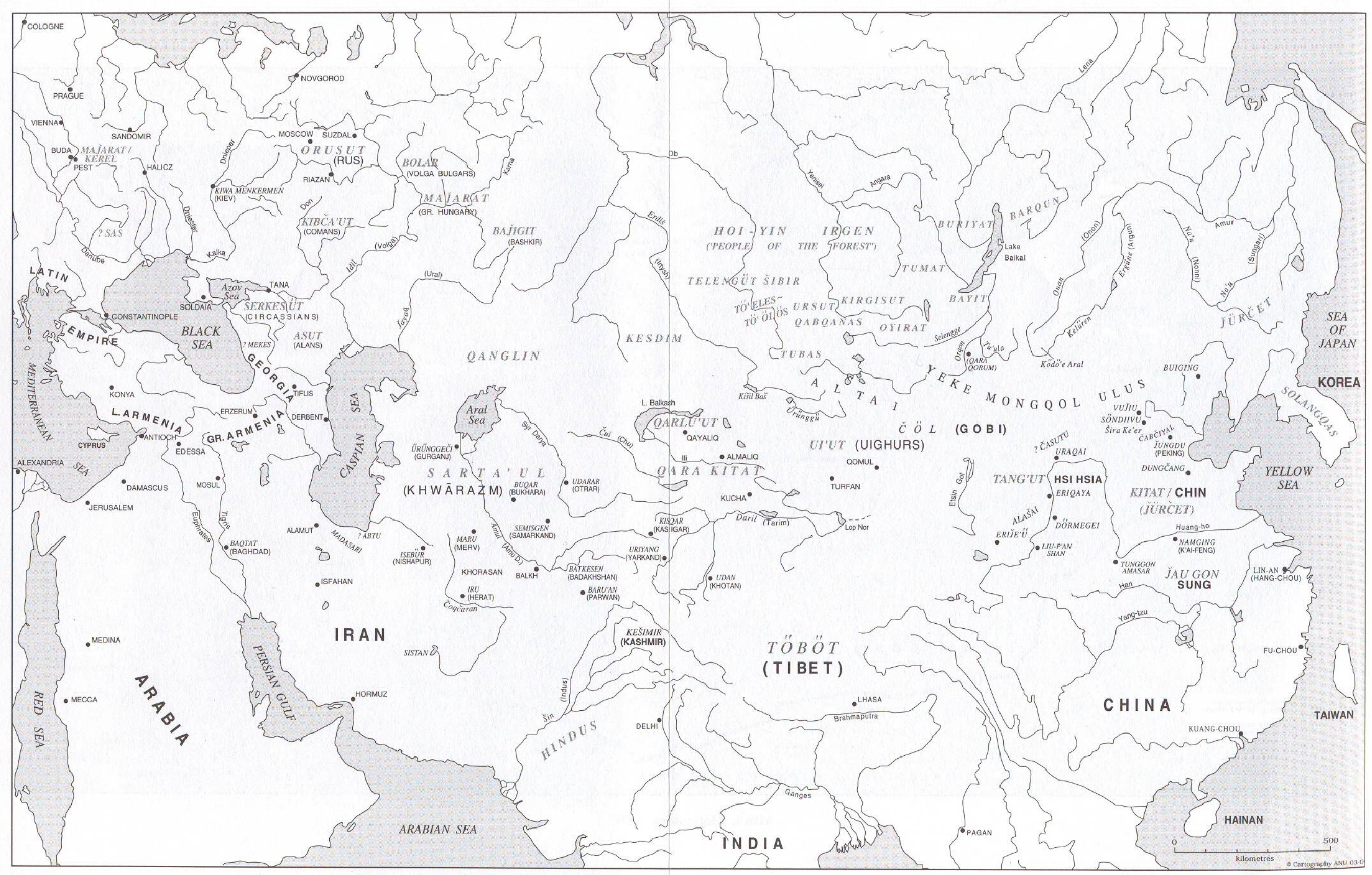

Map 2. Eurasia ca. AD 1210. 